UNIVERSIDADE DE SÃO PAULO

ESCOLA DE COMUNICAÇÕES E ARTES

DEPARTAMENTO DE COMUNICAÇÕES E ARTES

\title{
A FORMAÇÃO DO PROFESSOR NA UNIVERSIDADE PARA A INTER-RELAÇÃO COMUNICAÇÃO/EDUCAÇÃO
}

GABRIELA FELIPPE RODRIGUES METZKER 
UNIVERSIDADE DE SÃO PAULO

ESCOLA DE COMUNICAÇÕES E ARTES

DEPARTAMENTO DE COMUNICAÇÕES E ARTES

\title{
A FORMAÇÃO DO PROFESSOR NA UNIVERSIDADE PARA A INTER-RELAÇÃO COMUNICAÇÃO/EDUCAÇÃO
}

\author{
GABRIELA FELIPPE RODRIGUES METZKER
}

Dissertação apresentada junto ao Departamento de Comunicações e Artes da Escola de Comunicações e Artes da USP como requisito parcial para obtenção do título de Mestre em Ciências da Comunicação, área de concentração Interfaces Sociais da Comunicação, linha de pesquisa Educomunicação

Orientador: Prof. Dr. Adilson Odair Citelli

São Paulo

2010 
A Fabricio Metzker, pelo apoio em cada dia desta jornada, e a José e Vera Lúcia Rodrigues, por sempre terem incentivado a reflexão 
BANCA EXAMINADORA - SÃO PAULO, 2010 


\section{AGRADECIMENTOS}

Aos estudantes da USP e da UNICSUL que dedicaram parte de seu tempo, muitas vezes já tão concorrido, para dar sua contribuição. Agradeço muito pela maneira acolhedora com que me receberam e a seriedade que demonstraram com o trabalho de pesquisa. Agradeço também às duas universidades por manterem as portas sempre abertas.

Ao Prof. Dr. Adilson Citelli, pelas valiosas orientações e pela paciência em me ajudar a encontrar o melhor caminho. Sou profundamente grata pela oportunidade de ter cursado o Mestrado e mais ainda pelo privilégio de ter sido orientada por um autor/pesquisador cujo talento sempre admirei.

A meu marido, Fabricio Metzker, pelo apoio incondicional e companheirismo, mesmo nos muitos momentos em que me mostrei ausente.

A meus pais, José e Vera Lúcia Rodrigues, que ajudaram a despertar a paixão pelos livros e incentivaram a dedicação ao trabalho, e a meus irmãos, Gisele e Giovani Rodrigues, eternos companheiros.

À querida colega e amiga Eliana Nagamine, com quem compartilhei cada momento e cuja generosidade foi decisiva para a realização desta pesquisa.

Às amigas Edilaine Félix e Juliana Doretto, parceiras de todas as horas, com quem pude dividir as angústias da "estreia" em uma pós-graduação stricto sensu.

Aos amigos Karina Bueno, Diego Meneghetti e Sabine Righetti, pelo incentivo nos momentos mais difíceis desde os tempos da graduação.

Aos colegas de profissão, especialmente Ricardo Fotios e Roberto Moreno, pela paciência e estímulo aos estudos.

Aos professores do Programa de Pós-Graduação em Ciências da Comunicação, que tanto incentivaram a reflexão e o debate.

Aos colegas orientandos Ana Luisa Gomes, Elisângela Costa, Maria Almeida e Rogério Pellizari, que trouxeram apoio e troca de experiências nessa reta final.

Aos colegas do "quarteto da Educomunicacão", Eduardo Monteiro, Luci Ferraz e Eliana Nagamine, parceiros na realização dos trabalhos, e a todos os colegas do curso. 


\section{RESUMO}

$\mathrm{Na}$ sociedade contemporânea, a escola tornou-se espaço cruzado por uma variedade de signos e linguagens, resultado das novas formas de produzir, circular e receber o conhecimento, geradas pelos meios de comunicação e pelas novas tecnologias. O cotidiano do jovem em processo de escolarização é marcado por experiências com os meios audiovisuais, no entanto, na sala de aula, o discurso continua profundamente centrado na linguagem oral e escrita. $\mathrm{O}$ descompasso entre as formas de ensinar e as vivências do aluno dificulta o aprendizado na educação formal, pois, para que o estudante possa construir sentido a partir das mensagens transmitidas, é preciso haver campos de identificação comuns. O professor deveria usar a linguagem dos meios de comunicação e das novas tecnologias para se aproximar do aluno, fazendo da educação um processo comunicacional, e ajudá-lo a articular os conhecimentos obtidos dentro e fora do espaço escolar. No entanto, é essencial que a formação inicial docente prepare o professor para trabalhar essas questões. Por meio de pesquisa empírica qualitativa, investigamos se a universidade oferece na graduação disciplinas que aproximem os campos da educação e da comunicação e qual o posicionamento do futuro professor sobre essa inter-relação.

\section{PALAVRAS-CHAVE}

Comunicação; Educação; Professor; Tecnologia; Linguagem. 


\begin{abstract}
In contemporary society, the school became a space crossed by a variety of signs and languages, result of new ways to produce, operate and receive knowledge generated by media and new technologies. The quotidian of youth in schooling process is marked by experiences with audio visual media however in the classroom the discourse remains firmly focused on oral and written language. The gap between the teaching techniques and student experiences turns the learning of formal education more difficult because the student needs to establish common identification fields to capture the meaning from messages transmitted. The teacher should use media's language and new technologies to become closer to the student, making education a communication process and helping students to articulate the knowledge gained inside and outside the school. However, it is essential that the initial teacher education prepare teachers to work on these issues. Through qualitative empirical research, we investigate whether the university offers academic disciplines which bring together education and communication and the vision of future teachers about this interrelationship.
\end{abstract}

\title{
KEYWORDS
}

Communication; Education; Teacher; Technology; Language. 


\section{SUMÁRIO}

INTRODUÇÃ

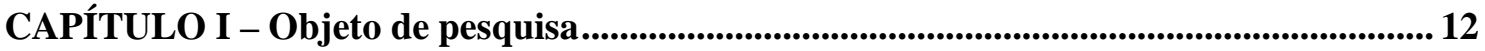

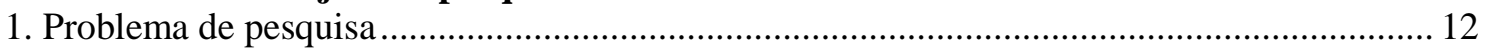

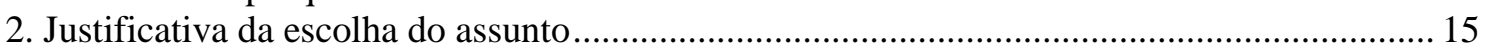

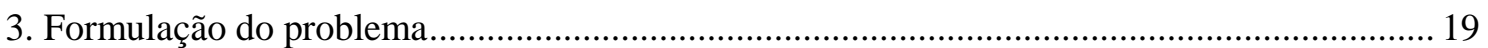

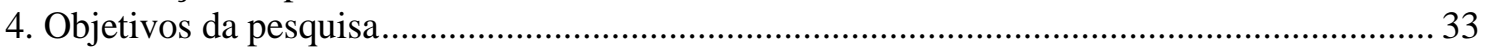

CAPÍTULO II - Quadro teórico de referência: relação comunicação/educação..................35

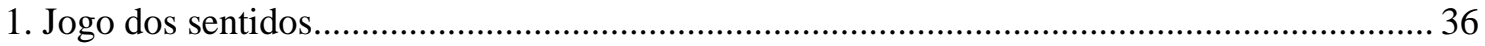

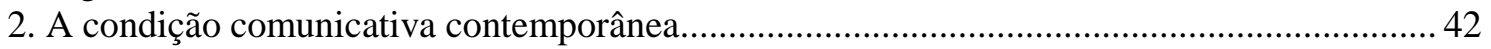

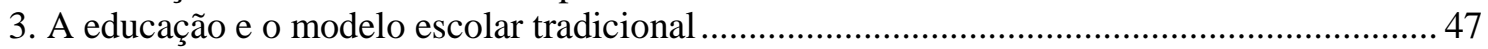

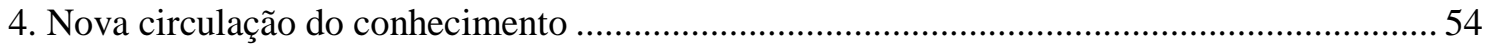

5. Replanejamento do processo educativo e formação de professores.......................................... 61

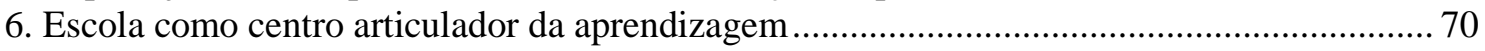

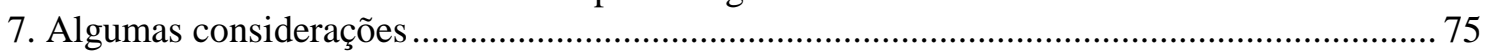

CAPÍTULO III - Hipóteses...................................................................................................... 76

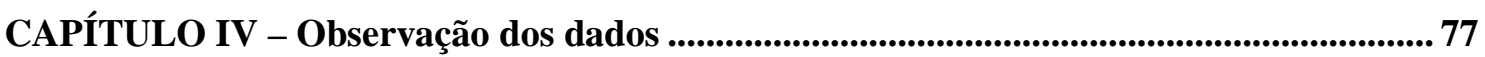

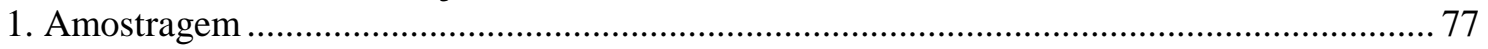

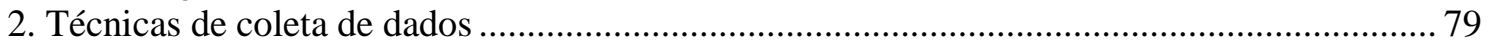

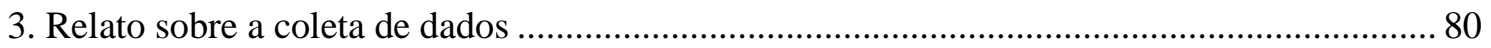

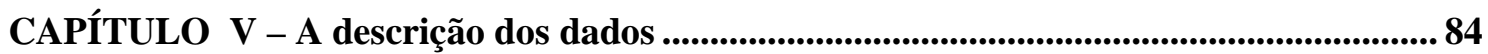

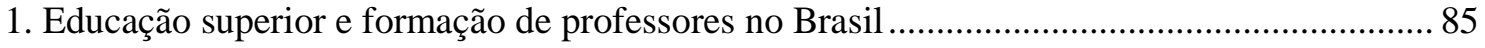

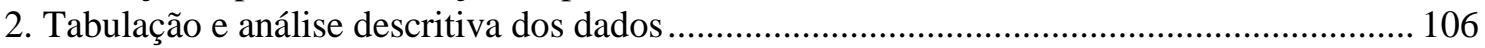

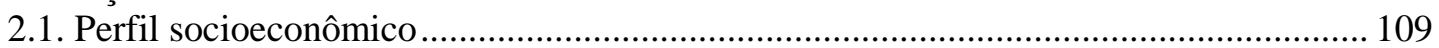

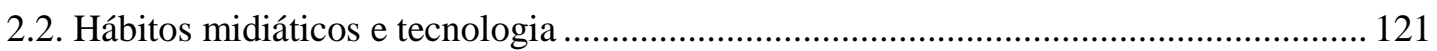

2.3. Formação para a inter-relação comunicação/educação ............................................... 139

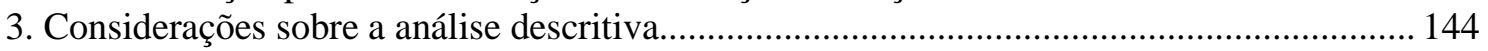

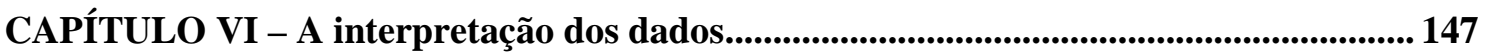

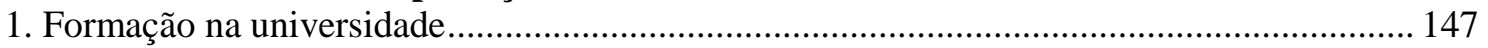

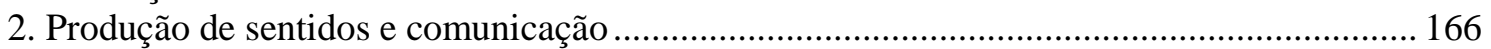

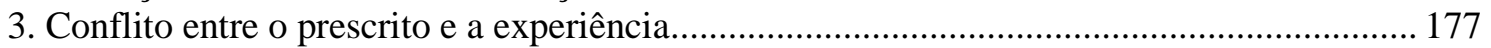

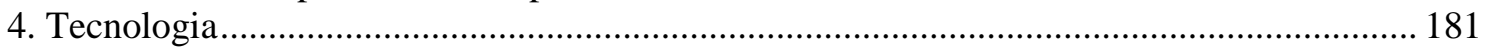

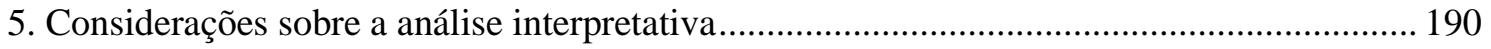

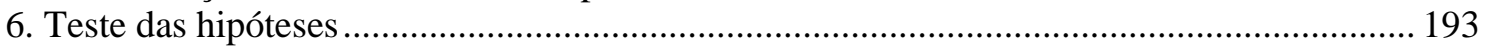

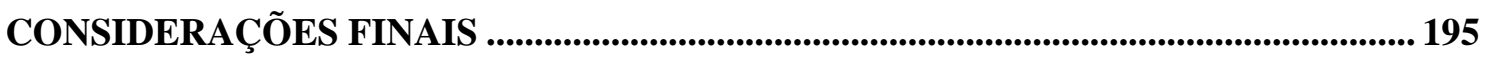

REFERÊNCIAS BIBLIOGRÁFICAS ................................................................................ 198

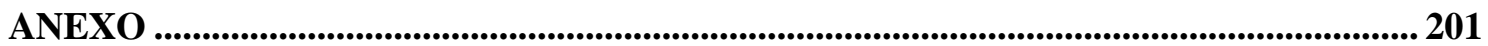




\section{INTRODUÇÃO}

Apresentamos a seguir a dissertação desenvolvida durante o curso de Mestrado, iniciado em 2008, na Escola de Comunicações e Artes da Universidade de São Paulo, dentro do Programa de Pós-Graduação em Ciências da Comunicação, área de concentração Interfaces Sociais da Comunicação, seguindo a linha de pesquisa Educomunicação, sob a orientação do Professor Doutor Adilson Odair Citelli.

A dissertação é apenas parte do trabalho realizado ao longo do curso, é "a ponta do iceberg" formado durante os estudos, a troca com os colegas e professores, a experiência da pesquisa de campo, enfim, o trabalho que apresentamos agora é a exteriorização de um conhecimento adquirido ao longo de nossa vivência acadêmica e social. Sabemos, no entanto, que essa jornada nos proporcionou também um conhecimento tácito, que não pode ser explicitado, mas que certamente será acionado nas mais diversas situações daqui em diante.

O Mestrado foi uma de nossas mais ricas experiências, não só pelo fato de termos estudado diferentes teóricos e elaborado uma série de trabalhos que exercitaram nossa capacidade de reflexão e articulação, mas principalmente pela oportunidade de conviver com os mais diversos pontos de vista. Durante as discussões na sala de aula, nas orientações, nos congressos de que participamos, nas reuniões em grupo e também nos momentos de descontração, seja na cantina, no restaurante ou nos bancos da universidade, tivemos a chance de debater, acompanhar outros raciocínios, conhecer novos olhares e assim ampliar nossos horizontes. Essa convivência com as pessoas certamente foi o grande diferencial, permitindo que nossa passagem por essa etapa da vida acadêmica se tornasse ainda mais enriquecedora.

O caminho é árduo, porém gratificante e, embora persista a sensação de que poderíamos ter feito mais, acreditamos que conseguimos adentrar o universo da pesquisa e compreender que um estudo científico vai além de teorias e métodos. Certamente embasamento, dedicação e disciplina são indispensáveis, mas uma pesquisa pede também sensibilidade e sentimento, afinal, convivemos por no mínimo dois anos com um objeto e acreditamos ser impossível não nos envolvermos com ele. Sabemos que é preciso distanciamento em muitos momentos para sua visualização, mas isso não impede o envolvimento, desde que haja rigor epistemológico e metodológico.

Nossa linha de pesquisa é a inter-relação dos campos da educação e da comunicação, vista pela perspectiva comunicacional. Ao longo da construção de nosso objeto teórico, defendemos que a interdiscursividade aproxima esses dois campos, pois 
as formas de produção dos sentidos foram alteradas na sociedade da informação e comunicação. Com o desenvolvimento das mídias e das novas tecnologias, temos atualmente novas formas de produzir, circular e receber o conhecimento, o qual não se restringe à escola. A educação formal é cercada por outras instâncias educativas que fazem circular uma variedade de signos e linguagens, ficando a compreensão das mensagens atrelada a diferentes mediações, pois o sentido não é predeterminado. Nesse processo, os meios de comunicação, especialmente aqueles ancorados nas novas tecnologias, ocupam um papel estratégico, de reconfiguradores sociais, cabendo à escola incorporar as novas linguagens para se aproximar do cotidiano do aluno e ajudálo a articular os conhecimentos obtidos nos mais diversos fluxos. Em nossas discussões, defendemos a educação como processo comunicacional, em que o professor tem o papel de facilitador da aprendizagem, rumo a uma formação emancipatória. Porém a própria formação docente precisa rumar nessa direção, por isso nosso objeto empírico são os cursos de graduação em Pedagogia e Letras da Universidade de São Paulo (USP) e da Universidade Cruzeiro do Sul (UNICSUL). Fomos a campo verificar se os cursos de formação docente oferecem disciplinas voltadas para a inter-relação comunicação e educação, bem como investigar o posicionamento dos estudantes sobre o uso dos meios de comunicação e das novas tecnologias em sala de aula. Nossa pesquisa de campo tem como centro o futuro professor, ou seja, todo o estudo é focado nos estudantes dos cursos de Pedagogia e Letras da USP e da UNICSUL. A formação universitária é investigada a partir de questionários e entrevistas com os alunos, juntamente com dados da grade curricular, além de informações secundárias oriundas de institutos oficiais de pesquisa. Portanto, não foi nossa intenção, nesse momento, investigar o posicionamento e os planos das universidades, mas sim verificar junto aos alunos qual a formação recebida na graduação para trabalhar a comunicação na escola. Pesquisamos também os hábitos midiáticos e a proximidade desses estudantes com as tecnologias, bem como suas visões sobre a educação, a comunicação e as práticas de ensino.

Apresentamos todo o percurso em seis capítulos, seguindo o modelo metodológico proposto por Maria Immacolata Vassalos de Lopes. No Capítulo I, definimos o objeto, com formulação do problema de pesquisa, justificativa da escolha do assunto e construção do objeto concreto, quando são apresentados os cursos e suas grades curriculares. No Capítulo II, desenvolvemos o objeto teórico, dialogando com autores que embasam nosso estudo, principalmente Adilson Citelli, Guillermo Orozco Gómez e Jesús Martín-Barbero. Em seguida, no Capítulo III, definimos o sistema de 
hipóteses, ou seja, as afirmações condicionais que têm o objetivo de orientar a pesquisa, as quais podem ser confirmadas ou rejeitadas ao término da investigação. O Capítulo IV, por sua vez, traz a observação dos dados, onde apresentamos a amostragem, as técnicas de coleta e nosso relato sobre o momento de ir a campo. No Capítulo V, realizamos a análise descritiva dos dados secundários sobre educação superior e formação de professores no Brasil e das informações obtidas por meio dos questionários, para então passarmos à interpretação dos dados, no Capítulo VI, quando objeto teórico e empírico finalmente se unem, levando a análise à condição de cientificidade. Nesse momento, procedemos ao teste das hipóteses, para então elaborarmos nossas considerações finais.

Ao longo de nossa dissertação, procuramos "objetivar a subjetividade", isto é, fazer um relato ao mesmo tempo objetivo e transparente, consciente de que o pesquisador tem um posicionamento e deve assumi-lo, sem tentar forjar uma neutralidade que não existe. 


\section{CAPÍTULO I - Objeto de pesquisa}

Realizamos estudo teórico e pesquisa empírica acerca da relação entre comunicação e educação, buscando verificar qual a formação do professor na universidade para esse tema e analisar como o profissional que em breve estará no mercado de trabalho compreende esse processo, como se relaciona com a mídia e com as novas tecnologias e como vê a comunicação traduzida em seu trabalho.

O modelo metodológico utilizado é o proposto por Maria Immacolata Vassallo de Lopes no Livro Pesquisa em Comunicação, cujos princípios básicos são a reflexão metodológica associada à implementação na investigação e a reflexão metodológica como uma maneira de se criar uma atitude consciente e crítica por parte do investigador. Nessa concepção metodológica, a pesquisa é considerada um campo dinâmico, que se configura como estrutura e como processo, ou seja, apresenta uma articulação de natureza "vertical" (entre níveis, instâncias ou dimensões - organizando-se como discurso científico) e outra de natureza "horizontal" (entre fases ou momentos da investigação - realizando-se como prática científica). "Assim entendido, o campo de pesquisa é definido essencialmente por uma dinâmica que resulta de uma rede de articulações verticais e horizontais tecida pelo raciocínio científico" (LOPES, 2005: 94).

Visto dessa forma, o campo da pesquisa não se reduz a fórmulas prontas, a normas rigidamente controladas, pelo contrário, permite interpenetrações das diversas instâncias do objeto e voltas constantes entre as operações envolvidas em suas fases. Lopes ressalta os equívocos que podem ser evitados com a adoção dessa concepção metodológica: "uma discussão formal e abstrata das questões epistemológicas, teóricas, metódicas e técnicas (...) e uma visão linear da pesquisa, responsável pela redução desta a um processo estandartizado e automático de operações" (LOPES, 2005: 98). Como não queremos cair nessa armadilha de fugir à prática concreta da investigação e de reduzi-la a um processo automático, iniciaremos agora a apresentação e discussão das fases da pesquisa que realizamos.

\section{Problema de pesquisa}

De acordo com Lopes, o problema de pesquisa situa-se num conjunto amplo, que é o assunto ou tema da pesquisa. O tema é escolhido pelo investigador; já o assunto é constituído por ele. $\mathrm{O}$ assunto traz em si uma problemática sempre vinculada a um modelo teórico, por isso, Lopes destaca que a especificação de um problema de pesquisa quase sempre resulta de um procedimento dedutivo. "Costuma-se partir de um 
problema abrangente até se conseguir a 'pergunta-chave' que a pesquisa pode responder" (LOPES, 2005:138). Aqui se inicia o exercício da vigilância epistemológica, conceito de Gaston Bachelard defendido por Lopes. O pesquisador deve ser questionador, rigoroso, dedicar o máximo de atenção ao seu problema de pesquisa. Segundo Lopes, esse exercício de vigilância começa a ser feito por meio da justificativa da escolha do assunto, "quando devem ser fundamentadas as razões que levaram a tal escolha" (LOPES, 2005: 138).

A afirmação de Bachelard, corroborada por Lopes e Bourdieu, de que "o objeto se conquista, se constrói e se comprova" foi a referência para todo este trabalho de pesquisa. "Defender juntamente com Bachelard que o fato científico é conquistado, construído e constatado é recusar, ao mesmo tempo, o empirismo que reduz o ato científico a uma constatação e o convencionalismo que lhe opõe somente as condições prévias da construção" (BOURDIEU, 1999: 22). A conquista se dá através da ruptura epistemológica - o pesquisador rompe com o senso comum e passa a questionar as aparências, tornando-se mais crítico e consciente. A partir daí, ele começa a construir o objeto através de conceitos, pois o objeto não é dado, e sim construído. Por último, é hora de comprovar o objeto por meio de exposições, testes e, assim, gerar o conhecimento científico.

A conquista e construção de meu objeto de pesquisa se iniciaram ainda na faculdade de Comunicação Social com habilitação em Jornalismo, pois foi a partir das aulas na UNESP de Bauru que comecei a me questionar sobre alguns pontos envolvendo comunicação e educação. Por que os meios de comunicação, com sua capacidade de falar diretamente ao público alvo, com sua linguagem atraente, com suas possibilidades de contribuir com o aprendizado, estão fora do espaço escolar? Por que a escola se detém apenas a métodos tradicionais de ensino e ignora as outras linguagens? Será que um aluno estereotipado como "problema" não precisaria apenas de estímulos que abrangessem as linguagens que circulam fora do espaço escolar? Fui buscar as respostas para essas e outras perguntas numa disciplina do curso de Artes chamada Psicologia da Educação. Lá, deparei-me com novas questões, mas percebi que as aulas, mesmo não pertencendo à grade de Jornalismo, tinham estreita ligação com o que eu acreditava e gostaria de fazer. A ideia era fugir do modelo tradicional de Educação, procurando adequar o ensino à realidade do aluno.

No projeto de conclusão de curso, em 2002, a união entre Comunicação e Educação tomou forma - desenvolvi o plano de uma revista voltada a crianças já 
alfabetizadas, cuja proposta era fornecer conteúdos educativos de forma lúdica e usando uma linguagem próxima ao universo do leitor. Estimular a criatividade, o raciocínio e incentivar a leitura eram os ousados objetivos dessa estudante de Jornalismo "metida a pedagoga", como muitos amigos me chamavam na faculdade, dada minha afinidade com o tema. Intuitivamente ou não, uma das pessoas da minha banca era uma pedagoga.

Depois, já formada e ansiosa para ingressar no mercado de trabalho, essas questões, infelizmente, ficaram um pouco esquecidas, ou melhor, dormentes. Porém a preocupação com a educação continuava ali: eu trabalhava numa editora que produz revistas destinadas à população de baixa renda e, a cada matéria que escrevia, pensava que aquela talvez fosse a única fonte de informação daquele leitor, pois os produtos eram vendidos a preços bem mais baixos que a média de mercado. Ao desenvolver a pauta, tentava pensar a matéria colocando não apenas informações úteis ao leitor, mas dando condições para ele refletir e realmente adquirir conhecimento. Essa não era uma tarefa fácil, uma vez que o ritmo acelerado da redação e a própria filosofia da empresa não contribuíam. Eu tinha que trabalhar nas brechas, mas ainda não havia me dado conta da relação dialógica existente entre comunicação e educação.

Entre 2005 e 2006, com o curso de especialização em Gestão de Processos Comunicacionais, comecei a encontrar algumas respostas para as minhas inquietações e a descobrir autores que trouxeram uma nova bagagem para essa discussão, de maneira a torná-la mais consistente. Foi aí que conheci o termo Educomunicação e compreendi que a comunicação e a educação não podem mais ser vistas como assuntos distintos. Uma está ligada à outra, estabelecendo relação dialógica entre elas.

Ao final do curso de especialização, desenvolvi um projeto de pesquisa com o objetivo de verificar como a comunicação é trabalhada na educação formal num colégio particular de São Paulo, sob orientação do Professor Doutor Ismar de Oliveira Soares. O trabalho permitiu conhecer novas abordagens sobre o tema comunicação/educação, bem como o primeiro contato com a pesquisa empírica, pois fui a campo coletar dados. A experiência foi bastante enriquecedora tanto do ponto de vista teórico quanto do metodológico porque possibilitou a prática da pesquisa, com todas as suas etapas, desdobramentos, dificuldades e implicações. Embora tenha sido um estudo qualitativo com amostragem restrita (três professores e 18 alunos) e desenvolvido apenas em um semestre, foi um exercício metodológico e um incentivo para dar continuidade aos estudos. O trabalho "Projeto de Intervenção Educomunicativa no Colégio Elvira Brandão" (RODRIGUES, 2006) foi defendido em dezembro de 2006. 
Em 2007, participei como aluna especial da disciplina "Linguagem, Comunicação e Educação", ministrada pelo Professor Doutor Adilson Odair Citelli no Programa de Pós-Graduação em Ciências da Comunicação da ECA-USP. Ali, conheci novos autores e me identifiquei com uma questão que, até então, ainda não havia estudado a fundo: a produção dos sentidos. Percebi que, se quisesse continuar os estudos sobre a interrelação comunicação/educação, teria necessariamente que verificar como os sentidos são construídos, desconstruídos e recebidos, afinal, a relação da comunicação com a educação depende de novas formas de produção dos sentidos. A partir daí, surgiu a ideia de trabalhar o tema partindo dessa nova perspectiva, com professores que em breve estarão no centro do processo. Entendi que um novo projeto seria viável, e o melhor seria atrelá-lo ao Mestrado, já que a orientação e as outras disciplinas cursadas seriam essenciais para o trabalho. Ingressei no Mestrado em 2008, na linha de pesquisa Educomunicação, como orientanda do Professor Doutor Adilson Odair Citelli, com a proposta de desenvolver pesquisa empírica junto a estudantes de licenciatura de universidades públicas e privadas para verificar qual a formação que os futuros professores recebem na graduação no que se refere a esse tema e como eles entendem a relação comunicação/ educação.

\section{Justificativa da escolha do assunto}

Sou jornalista de formação, atuo como jornalista e sempre me interessei por estudar a comunicação. Porém o tema Educação também me acompanhou ao longo de minha trajetória. Minha mãe é professora e trazia para casa questões vividas em sala de aula. Costumávamos discutir sobre o que define um "bom aluno" e um "bom professor", por que determinado estudante não se interessa pelo conteúdo apresentado, o tipo de aula de que os alunos mais gostam, enfim, o assunto estava sempre presente nas conversas. Na graduação, tive a oportunidade de conhecer mais sobre o tema educação paralelamente aos estudos da comunicação. Já na pós-graduação, quando pude aproximar os dois campos e inter-relacioná-los, encontrei o ponto de intersecção que buscava. Embora jamais tivesse lecionado, poderia estudar a educação do ponto de vista da comunicação.

Essa perspectiva se revelou animadora e viável. Se, por um lado, o fato de não ser professora traz a desvantagem de não estar plenamente inserida no universo estudado, por outro, traz a vantagem de ter o olhar de fora, um olhar menos envolvido nas questões educacionais, escapando ao perigo da hiperespecialização do pesquisador, 
como lembra Edgar Morin. Dessa forma, rompendo as limitações entre as disciplinas, corremos menos risco de "coisificar" o objeto estudado, evitando pensar que ele seja autossuficiente, em vez de construído. Morin alerta que, nessa falsa percepção, “as ligações e solidariedades desse objeto com outros objetos estudados por outras disciplinas serão negligenciadas, assim como as ligações e solidariedades com o universo do qual ele faz parte" (MORIN, 2006: 106). O olhar de fora facilita o rompimento das fronteiras disciplinares e, como lembra Lopes, o campo da comunicação caminha cada vez mais para a transdiciplinarização, superando as especialidades fechadas e hierarquizadas.

Além disso, como minha proposta parte da perspectiva comunicacional, a experiência como docente não se mostra indispensável. Certamente essa posição descentrada trouxe algumas limitações, especialmente no momento de ir a campo, já que não tinha acesso a outras universidades, porém as limitações puderam ser contornadas com o trabalho sério, rigoroso e vigilante que uma pesquisa exige, e com sensibilidade às questões educacionais. Acredito que a sensibilidade, aliás, mostra-se essencial para adentrar o campo da educação e inter-relacioná-lo com o da comunicação, sempre com embasamento teórico e metodológico.

Além da afinidade, a relevância teórica e social também contribuíram para a decisão de escolher esse tema, afinal, a educação formal, aquela educação normatizada, regida por uma legislação específica, tem encontrado muitos desafios na sociedade contemporânea, especialmente em decorrência das novas formas de produzir, circular e receber o conhecimento geradas pelos meios de comunicação e pelas novas tecnologias. A escola teve dificuldade para acompanhar essas transformações, ficando em descompasso com as novas linguagens em circulação, como destaca Citelli: “Talvez o termo descompasso seja o mais adequado para designar a situação presente vivida pelas escolas dos ciclos fundamental e médio diante dos meios de comunicação e das novas tecnologias" (CITELLI, 2000: 21).

José Joaquín Brunner afirma que a educação tem sido basicamente uma "empresa low tech", baseada na oralidade: "usa a palavra do professor - na proporção de 125 a 200 palavras por minuto - durante algumas horas por dia, o lápis, o giz e o quadronegro, os textos impressos e (...) o retroprojetor" (BRUNNER, 2004: 45). Segundo o autor, o rádio, o cinema e a televisão não conseguiram alterar a forma de ensinar na escola, embora tenham permitido o desenvolvimento de modalidades de educação a distância. Já com a chegada das novas tecnologias, especialmente o computador e a 
internet, a "instituição inabalável" começou a ser pressionada pelas novas linguagens e dinâmicas em circulação.

Trazer os meios de comunicação para a escola, no entanto, não significa apenas dispor das tecnologias para reforçar os métodos existentes. O processo deve ser muito mais profundo, pensado a partir das novas formas de produção, circulação e recepção do conhecimento. Segundo Jesús Martín-Barbero, com a introdução do hipertexto e da linguagem audiovisual no cotidiano da sociedade, as maneiras de aprender estão se transformando, especialmente entre as crianças e jovens. Os fluxos gerados pelas transformações tecnológicas estão desorganizando a circulação dos saberes, o que representa uma profunda mudança na sociedade. Martín-Barbero lembra que o saber, até agora, esteve localizado territorialmente, controlado por dispositivos técnicopolíticos e associado a determinadas figuras sociais, porém, com o advento dos meios de comunicação e das tecnologias digitais, o saber está descentrado, com instâncias educadoras atuando por toda parte. "De ahí que las transformaciones en los modos cómo circula el saber constituya una de las más profundas transformaciones que una sociedad puede sufrir" (MARTÍN-BARBERO, 2008: 11). Brunner também identifica o descentramento sofrido pela escola bem como o acionamento de novos mecanismos de aprendizagem:

“... as novas tecnologias da informação e da comunicação, particularmente as tecnologias de rede, estão modificando um dos princípios axiais da ordem escolar (o isolamento da escola), assim como um dos elementos constitutivos da aprendizagem (o texto plano ou linear), que começa a ser substituído pelo hipertexto." (BRUNNER, 2004: 46)

Com o aporte das novas tecnologias, os veículos de comunicação tornaram-se "escolas paralelas", exigindo uma nova postura do sistema educativo, como aponta Maria da Glória Gohn: "O setor dos meios de comunicação sofreu uma revolução tecnológica, gerou novas relações sociais, novas linguagens, alterou estilos e comportamentos sociais, transformou a cultura e colocou novos desafios e necessidades à área da Educação" (GOHN, 2008: 8). A autora observa uma ampliação do conceito de educação na sociedade marcada pelas novas tecnologias de comunicação e informação. Segundo Gohn, a educação extrapolou o interior das unidades escolares, não se restrigindo mais aos processos de ensino-aprendizagem em sala de aula. Para a autora, a educação está associada à cultura, representando, portanto, formas de ensino/aprendizagem adquiridas ao longo da vida, nos "espaços da casa, do trabalho, do lazer, do associativismo" (GOHN, 2008: 7). 
Paulo Freire também se refere à educação nesse sentido mais amplo, enfatizando que a visão limitada do que é ensinar e aprender acaba por associar a educação à transferência do saber. "No fundo, passa despercebido a nós que foi aprendendo socialmente que mulheres e homens, historicamente, descobriram que é possível ensinar" (FREIRE, 1996: 44). Segundo o educador, se a compreensão de ensino estivesse associada ao aprendizado que precedeu essa experiência, nós entenderíamos a importância do que ele chama de experiências informais, ou seja, as conversas nas ruas, no trabalho, na sala de aula, nos recreios, "em que variados gestos de alunos, de pessoal administrativo, de pessoal docente se cruzam carregados de significação. Há uma natureza testemunhal nos espaços tão lamentavelmente relegados da escola" (FREIRE, 1996: 44).

Dentro da abrangência do conceito de educação, Maria da Glória Gohn faz três diferenciações: educação formal, não-formal e informal. A primeira diz respeito à escola propriamente dita, instituição normatizada, oficial; a educação não-formal remete aos processos educativos desenvolvidos em movimentos, organizações e associações sociais, cujos conteúdos são voltados ao ensino-aprendizagem, porém sem o vínculo normativo da escola e apresentados de maneira flexível, com tempo e espaço distintos daqueles adotados na educação formal: "Como existe a flexibilidade no estabelecimento dos conteúdos, segundo os objetivos do grupo, a forma de operacionalizar esses conteúdos também tem diferentes dimensões" (GOHN, 2008: 101). Já a educação informal abrange o aprendizado decorrente do convívio com a família e amigos, da leitura de jornais e revistas, do ato de ver televisão etc. Os conteúdos veiculados pela mídia situam-se, portanto, no terreno da educação informal, decorrentes de processos em que não há a intencionalidade de uma formação específica. "O que diferencia a educação não-formal da informal é que na primeira existe a intencionalidade de dados sujeitos em criar ou buscar determinadas qualidades e/ou objetivos" (GOHN, 2008: 100).

Diante desse cenário de novos saberes em circulação, em que a educação não se restringe aos muros da escola, o discurso pedagógico tradicional, baseado na oralidade e no monologismo, mostra-se limitado, bem como a preparação da escola para lidar com as novas linguagens, exigindo o repensar do processo educativo. O professor, elementochave, também se encontra afastado da nova configuração tecnológica. Como nos lembra Brunner, a formação e a capacitação de professores, embora apresentem iniciativas nesse sentido, ainda estão longe de satisfazer as demandas de um novo 
processo educativo. "As faculdades e escolas de pedagogia mantêm, basicamente, a mesma orientação e estrutura desde o último quarto do século passado, não tendo adotado as redefinições e os redesenhos que seriam necessários para abordar os desafios da sociedade da informação" (BRUNNER, 2004: 71). Pelo termo "sociedade da informação", o autor compreende uma sociedade emergente que está em processo de formação, estruturada em redes e baseada na convergência das novas tecnologias de informação e comunicação. Para Brunner, o treinamento de professores ainda se limita a uma alfabetização tecnológica e uso elementar, predominando uma visão instrumental das tecnologias.

"Só uma ínfima porcentagem dos docentes teve a oportunidade de fazer cursos ou desenvolver práticas formativas sobre o uso educacional das novas tecnologias e sobre sua utilização em processos de aprendizagem fora da escola. Contudo, mesmo nesses casos se mantêm em vigor a concepção educacional e os conceitos operativos próprios da pedagogia tradicional. Por exemplo, os grandes avanços das ciências cognitivas não foram incorporados (não suficientemente, ao menos), e tampouco a formação e capacitação dos professores foi impregnada de uma visão ‘da educação e da mente na era do conhecimento'.” (BRUNNER, 2004: 71)

No quadro teórico de referência, iremos aprofundar o debate a respeito dessas questões, destacando a necessidade de a escola incorporar as novas linguagens, sobretudo porque elas influenciam a constituição de campos de sentido, e os obstáculos que se abrem ao replanejamento do processo educativo. Por enquanto, nosso objetivo foi apresentar o cenário que justifica a relevância do tema enquanto motivador de uma pesquisa voltada à formação de professores no que tange à inter-relação comunicação/ educação.

\section{Formulação do problema}

O objeto concreto de nossa pesquisa são dois cursos de graduação de duas universidades localizadas na cidade de São Paulo, USP (Universidade de São Paulo) e UNICSUL (Universidade Cruzeiro do Sul). Fizemos a opção por essas universidades para trabalharmos com uma instituição pública e uma privada, de forma a diversificar a amostra. Pretendemos verificar qual a formação ligada à inter-relação comunicação/ educação que o futuro professor recebe na universidade e como ele entende essa relação. O futuro profissional acredita na importância da integração entre comunicação e educação? Como ele vê essa aproximação traduzida em seu trabalho? Qual seu posicionamento sobre o uso dos meios em sala de aula? Como é sua formação 
acadêmica a respeito dessas questões? Como o futuro professor se relaciona com a mídia e as novas tecnologias?

Acreditamos que a inter-relação comunicação/educação deve perpassar o ensino de todas as disciplinas, porém, para a viabilidade da pesquisa, focamos nosso estudo em dois cursos da área de Humanas: Pedagogia e Letras.

\subsection{Universidades e cursos pesquisados}

Descrevemos a seguir as universidades pesquisadas e a constituição de seus respectivos cursos, de forma a conhecermos melhor nosso objeto.

\section{UNICSUL}

A Universidade Cruzeiro do Sul teve origem como Colégio Cruzeiro do Sul, em 1965, passando a Faculdades Cruzeiro do Sul em 1972 e finalmente a Universidade, em 1993. Essa instituição privada de ensino superior abrange quatro campi na cidade de São Paulo, nos bairros de Anália Franco, Liberdade, Pinheiros e São Miguel Paulista. Nosso estudo se concentra no campus de São Miguel Paulista, localizado na zona leste de São Paulo, por ser o único a contar com turmas de Letras e Pedagogia que estivessem no final do curso em 2009, quando realizamos a pesquisa de campo na universidade. O campus de Pinheiros também oferece os dois cursos, porém havia somente turmas de primeiro e segundo ano, e nosso foco são os alunos dos últimos semestres.

O curso de Licenciatura plena em Pedagogia da UNICSUL tem duração de seis semestres. Em sua página oficial ${ }^{1}$, a universidade destaca que a docência e a gestão educacional são os focos do curso e ressalta que disponibiliza brinquedoteca e laboratório de informática educativa aos alunos. No campus de São Miguel Paulista, o valor da mensalidade, em 2010, é de R \$336,17 (sendo seis parcelas por semestre, além da matrícula), e o curso matutino, objeto de nossa pesquisa, é ministrado de segunda a sexta-feira, das $8 \mathrm{~h}$ às $11 \mathrm{~h} 35$, sendo que $20 \%$ da carga horária é oferecida na modalidade semipresencial. A graduação em Pedagogia conta com 52 disciplinas, sendo 43 obrigatórias e 9 optativas, das quais o aluno deve cursar duas.

\footnotetext{
${ }^{1}$ http://www.cruzeirodosul.edu.br
} 


\section{Disciplinas obrigatórias:}

\section{Pedagogia - UNICSUL}

Alfabetização e letramento

Avaliação educacional

Corpo, movimento e psicomotricidade

Dificuldades de aprendizagem

Diversidade étnico-cultural

Economia da Educação

Educação de jovens e adultos: fundamentos e práticas

Educação e saúde

Educação inclusiva

Educação infantil: currículo

Educação: jogos e brincadeiras

Educação, movimentos populares e transformação

Educação não-formal

Escola, currículo e sociedade

Escola, família e comunidade

Estágio curricular supervisionado nos anos iniciais do ensino fundamental

Estágio curricular supervisionado em Educação Infantil

Estágio curricular supervisionado na gestão educacional

Estatística aplicada à Educação

Estudos dirigidos

Estudos dirigidos I

Estudos dirigidos II

Estudos dirigidos III

Estudos dirigidos IV

Estudos dirigidos $\mathrm{V}$

Filosofia na Educação

Fundamentos metodológicos do ensino de História e Geografia I

Fundamentos metodológicos do ensino de História e Geografia II

Fundamentos metodológicos do ensino de Arte e Música I

Fundamentos metodológicos do ensino de Arte e Música II

Fundamentos metodológicos do ensino de Ciências I

Fundamentos metodológicos do ensino de Ciências II

Fundamentos metodológicos do ensino de Matemática I

Fundamentos metodológicos do ensino de Matemática II

Gestão e planejamento educacional: organização do trabalho pedagógico I

Gestão e planejamento educacional: organização do trabalho pedagógico II

História da Educação e da Pedagogia

História da Educação no Brasil

Legislação da Educação Básica e políticas educacionais

Língua brasileira de sinais

Língua portuguesa 
Metodologia de pesquisa

Total: 43 disciplinas obrigatórias

\section{Disciplinas optativas:}

Organização do trabalho docente

Pensamento, linguagem e desenvolvimento humano

Políticas públicas e Educação Infantil

Prática de ensino e orientação de estrutura curricular sup. na gestão educacional

Prática de ensino e orientação de estrutura curricular sup. nos anos iniciais do Ensino

Fundamental

Prática de ensino e orientação de estrutura curricular sup. em Educação Infantil

Psicologia da Educação

Sociologia

Tecnologias da Informação e da Comunicação

Total: 9 disciplinas optativas

\section{Total geral: 52 disciplinas}

O curso de Letras da UNICSUL é oferecido como Licenciatura plena com habilitação dupla em Português/Inglês. A universidade destaca que a graduação volta-se à formação de professores para Educação Infantil, Ensino Fundamental e Ensino Médio. Ministrado em seis semestres, o curso matutino, alvo de nossa pesquisa, tem aulas de segunda-feira a sábado, das $8 \mathrm{~h}$ às $11 \mathrm{~h} 35$, e $20 \%$ da carga horária é oferecida na modalidade semipresencial. O valor da mensalidade no campus de São Miguel Paulista, em 2010, é de R \$ 310,74 (sendo seis parcelas por semestre, além da matrícula). O curso oferece 36 disciplinas obrigatórias e 11 optativas, das quais o aluno deve escolher duas.

\begin{tabular}{|l|}
\hline \multicolumn{1}{|c|}{ Letras com habilitação em Português/Inglês - UNICSUL } \\
\hline Disciplinas obrigatórias: \\
\hline Didática \\
\hline Estágio curricular supervisionado em língua portuguesa I \\
\hline Estágio curricular supervisionado em língua portuguesa II \\
\hline Estágio curricular supervisionado em língua inglesa I \\
\hline Estágio curricular supervisionado em língua inglesa II \\
\hline Estudos dirigidos \\
\hline Estudos dirigidos I \\
\hline Estudos dirigidos II \\
\hline Estudos dirigidos III \\
\hline Legislação da Educação Básica e políticas educacionais \\
\hline Leitura e produção de textos em língua portuguesa: usos da linguagem \\
\hline Leitura e produção de textos em língua portuguesa: tipologias discursivas \\
\hline
\end{tabular}


Língua brasileira de sinais

Língua inglesa: aspectos histórico-culturais

Língua inglesa I

Língua inglesa II

Língua inglesa III

Língua inglesa IV

Língua inglesa $\mathrm{V}$

Língua portuguesa: estudos estilísticos e semânticos

Língua portuguesa: estudos gramaticais

Língua portuguesa: fonética e fonologia

Língua portuguesa: linguística textual

Língua portuguesa: morfologia

Língua portuguesa: sintaxe

Linguística

Literatura brasileira: poética

Literatura brasileira: prosa

Literatura inglesa

Literatura inglesa e norte-americana

Literatura portuguesa: poética

Literatura portuguesa: prosa

Metodologia de ensino de língua inglesa I

Metodologia de ensino de língua inglesa II

Metodologia de ensino de língua portuguesa I

Metodologia de ensino de língua portuguesa II

Total: 36 disciplinas obrigatórias

\section{Disciplinas optativas:}

Prática de ensino e orientação de estrutura curricular sup. em língua portuguesa I

Prática de ensino e orientação de estrutura curricular sup. em língua portuguesa II

Prática de ensino e orientação de estrutura curricular sup. em língua inglesa I

Prática de ensino e orientação de estrutura curricular sup. em língua inglesa II

Produção oral em língua inglesa I

Produção oral em língua inglesa II

Produção oral em língua inglesa III

Produção oral em língua inglesa: variantes linguísticas

Psicologia da Educação

Teoria da literatura: poética

Teoria da literatura: prosa

Total: 11 disciplinas optativas

\section{Total geral: 47 disciplinas}




\section{USP}

Fundada em 1934, a Universidade de São Paulo (USP) é uma instituição estadual de ensino superior e oferece 229 cursos de graduação a quase 56 mil alunos, distribuídos em 40 unidades localizadas na capital e no interior de São Paulo. Nosso estudo concentrou-se no campus Cidade Universitária, localizado no bairro do Butantã, zona oeste de São Paulo.

O curso de Pedagogia da USP, em São Paulo (SP), é oferecido gratuitamente pela Faculdade de Educação como Licenciatura plena, com duração mínima de oito semestres. Ao concluir a graduação, o profissional está habilitado a lecionar na educação infantil e no primeiro ciclo do Ensino Fundamental, bem como desenvolver atividades de direção, coordenação e supervisão educacional. A graduação compreende 36 disciplinas obrigatórias e 12 eletivas, as quais permitem ao aluno, segundo a página oficial $^{2}$ da faculdade, direcionar sua formação de acordo com seus interesses e aptidões. A grade curricular vespertina, foco de nossa pesquisa, oferece, além das 36 disciplinas obrigatórias, 104 optativas eletivas e 33 optativas livres.

\begin{tabular}{|l|}
\hline \multicolumn{1}{|c|}{ Pedagogia - USP } \\
\hline Disciplinas obrigatórias \\
\hline A Constituição da Subjetividade: Infância e Adolescência \\
\hline Atividades Práticas I - Estágios e Projetos \\
\hline Atividades Práticas II - Estágios e Projetos \\
\hline Atividades Práticas III - Estágios e Projetos \\
\hline Atividades Práticas IV - Estágios e Projetos \\
\hline Atividades Práticas V - Estágios e Projetos \\
\hline Coordenação do Trabalho na Escola I \\
\hline Coordenação do Trabalho na Escola II \\
\hline Currículos e Programas \\
\hline Didática I \\
\hline Didática II \\
\hline Educação Especial - Fundamentos, Políticas e Práticas Escolares \\
\hline Edução Infantil \\
\hline Estudos Independentes I \\
\hline Estudos Independentes II \\
\hline Estudos Independentes III \\
\hline Estudos Independentes IV \\
\hline Estudos Independentes V \\
\hline Estudos Independentes VI \\
\hline Estudos Independentes VII \\
\hline
\end{tabular}

\footnotetext{
${ }^{2}$ http://www.fe.usp.br/
} 
Estudos Independentes VIII

Filosofia da Educação I

Filosofia da Educação II (questões de Educação e Cultura no Pensamento Filosófico)

Fundamentos Econômicos da Educação

História da Educação I (geral-clássica, Idade Média e Renascimento)

História da Educação II

Metodologia de Ensino de Arte e Movimento Corporal

Metodologia do Ensino de Ciências

Metodologia do Ensino de História e Geografia

Metodologia do Ensino de Matemática

Metodologia do Ensino de Português: a Alfabetização

Política e Organização da Educação Básica I - Poeb I

Política e Organização da Educação Básica II - Poeb II

Psicologia da Educação I (a Capacidade Cognitiva e Potencialidade Humana para

Aprender)

Sociologia da Educação I

Sociologia da Educação II

Total: 36 disciplinas obrigatórias

\section{Disciplinas optativas eletivas}

Atividades de Cultura e Extensão: Práticas Formativas

A Adolescência na Contemporaneidade: Uma Abordagem Psicanalítica e Filosófica

A Educação Popular no Brasil

A Escola e a Cultura Brasileira

A Escrita no Ensino Fundamental: das Letras aos Textos

A Indústria Cultural e o Hip Hop: Uma Reflexão Sobre a Cultura de Massas, a Música de Contestação Urbana e o Acesso ao Masculino nas Metrópoles.

A Obra de Pierre Bourdieu: Uma Interpretação.

A Teoria Histórico Cultural

Afetividade como Valor e os Impasses Educativos

Análise Psicológica do Cotidiano Escolar

Arte e Educação Infantil I : Música e Arte Visuais

Arte, Cultura e Política: Brasil nos Anos 1950-70

Artes e Educação Infantil II: Dança e Teatro

Biologia e Educação

Brinquedos e Brincadeiras na Educação Infantil

Comunicação, Educação e Multimídia

Conhecimento e Mercadoria: Um Estudo Sobre os Processos de Mercantilização da

Educação, da Ciência, da Tecnologia e da Cultura

Construindo Um Projeto de Pesquisa na Área da Educação - Questões Epistemológicas e

Práticas

Cultura \& Educação III: Mitologias - Uma Introdução

Cultura Corporal: Fundamentação, Metodologia e Vivências

Cultura e Educação I: Teoria da Complexidade e Cultura Escolar

Cultura e Educação II: Imaginário e Processos Simbólicos 
Cultura e Organização I: a Multidimensionalidade do Fenômeno Sócio-Organizacional Educativo

Cultura e Organização II: Discursos e Práticas Socioculturais nas Organizações

Educativas

Educação e Atualidade - a Questão do Sujeito

Educação e Cultura Brasileira

Educação e Ética

Educação e Infância Problemática: Elementos de Psicanálise e Educação Especial

Educação e Pesquisa:história da Educação

Educação Escolar de Jovens e Adultos

Educação Especial: Abordagens e Tendências na Área da Deficiência Intelectual

Educação Especial: Abordagens e Tendências na Área da Deficiência Visual

Educação Infantil e Sociedade

Educação Matemática

Educação Nutricional

Educação para a Cidadania: a Ideia de "Pólis" Educadora nos Debates Filosóficos da

Atenas dos Séculos V e IV

Educação Privada e Educação Pública em Rousseau

Educação, Meio Ambiente e Sociedade

Educação: Caráter Universal e Relativismo Histórico

Educar para Um Outro Mundo Possível

Ensino à Distância

Ética e Educação Moral em Tomás de Aquino

Filosofia da Educação (Filosofia, Cultura e Educação)

Filosofia da Educação: Escolaridade e Ensino

Financiamento da Educação Básica no Brasil

Financiamento da Educação Básica no Brasil: Os Anos 2000

Freud e os Fundamentos da Educação

Freud, a Educação e a Pedagogia

História da Educação Brasileira IV (a Ideia de Universidade no Brasil)

História da Educação Geral (greco-romana)

História da Educação na Antiguidade Grega (das Origens ao Século IV A. C)

História da Escolarização Elementar no Brasil

História da Escrita e da Leitura na Escola Primária no Brasil

História da Infância e da Família

História das Ciências

História de Educação Moderna e Contemporânea: Os Pedagogos 'Menores'

Histórias da Educação de Pessoas Jovens e Adultas: Tempos, Espaços, Práticas, Discursos

Introdução à Pesquisa Educacional

Juventude e Educação

Leitura e Produção de Textos (EDM0683)

Leitura e Produção de Textos (EDM0690)

LIBRAS - Língua Brasileira de Sinais

Linguagem e Conhecimento

Memória e Memórias de Formação e de Leitura 
Memórias, Romances de Formação e Autobiografias e o Estudo das Questões Educacionais

Metodologia do Ensino de Linguística I

Metodologia do Ensino de Linguística II

Metodologia do Ensino de Psicologia I

Metodologia do Ensino de Psicologia II

Metodologia e Fundamentos da Alfabetização em Países de Língua Oficial Portuguesa: uma introdução

Metodologia e Fundamentos da Alfabetização/ Letramento de Jovens e Adultos

Mídia e Educação: Um Debate Contemporâneo

Multiculturalismo e Educação: Introdução à Temática

Música e Formação de Professores

Natureza, Cultura Científica e Educação

O Ensino e a Aprendizagem das Artes Visuais, Projeto Curricular e Projeto Políticopedagógico

O Pensamento de Rousseau em Educação

O Projeto Educativo de Platão

Paulo Freire - Teoria, Método e Práxis

Políticas de Atendimento à Alunos com Necessidades Educacionais Especiais

Políticas Sociais e Educação Especial: a Construção de Práticas Intersetoriais.

Processos de Transmissão Cultural e Formas de Educar Homens e Mulheres na Colônia e no Império (século Xvi - Xix)

Produção Audiovisual e Multimídia para o Ensino de Ciências

Psicanálise, Infância e Educação

Psicologia e Educação: Uma Abordagem do Cotidiano Escolar

Questões de Teoria do Ensino I

Relações de Gênero e Educação I: Trabalho, Educação e Gênero

Relações de Gênero e Educação Ii: Escola e Relações de Gênero

Seminários de Administração Escolar I

Seminários de Administração Escolar II

Seminários de Cultura Escolar I

Seminários de Cultura Escolar II

Seminários de Economia Política da Educação I

Seminários de Economia Política da Educação II

Seminários de Política Educacional I: Modalidades da Educação Básica

Seminários de Política Educacional II: Tópicos Atuais

Sociedade de Controle e Educação

Sociologia da Educação III (Sociedade, Política e Educação)

Sociologia da Educação IV (Estado, Instituições Educacionais e Mudanças Sociais)

Teatro Grego e Educação

Temas Transversais em Educação

Teoria dos Campos Sociais: gênese e Estrutura

Teoria e Prática do Estatuto da Criança e do Adolescente na Educação

Texto e Imagem: Literatura para Crianças na Escola

Tópicos de Psicologia Cultural 
'Trabalho e Educação na Sociedade Brasileira'

Uma Introdução a História do Século XX : Cultura e Educação

\section{Total: 104 disciplinas optativas eletivas}

\section{Disciplinas optativas livres}

A Historiografia em Transformação: Brasil, 1889 - 1960

Arte e Imaginário Contemporâneo

Arte Moderna e Contemporânea no Século XX no Acervo do MAC

Bioquímica e Biologia Molecular: Realizações e Perspectivas

Bioquímica: Metabolismo e Biologia Molecular

Educação Física na Educação Infantil

Educação Física no Ensino Fundamental I

Educação Física no Ensino Fundamental II

Educação Física no Ensino Médio

Elementos de Geodésia

Escrita e estilo em estudos literários

Estado e Cultura no Brasil: políticas para as artes

Estatística Descritiva

Físico - Química IV

Fontes e Interpretação do Brasil Oitocentista

Fundamentos da Educação Física Escolar I

Fundamentos da Educação Física Escolar II

Fundamentos de Sismologia

Gênero, arte e sociedade

Gêneros híbridos: crônica, carta, poema em prosa

História Econômica do Trabalho no Brasil

História, Cultura Popular e Folhetos de Cordel no Brasil

Indústria, Desenvolvimento Econômico e Projeto Nacional no Brasil

Interdisciplinaridade nas Artes Contemporâneas: Arte / Dança / Performance / Instalação

Introdução à Astronomia

Introdução à Petrofísica

Laboratório de Matemática Aplicada

Monitoria em Arte Visual

Noções de Estatística

Pesquisa e Desenvolvimento em Química

Química de Biomoléculas

Química Geral

Trabalho Complementar de Curso

Total: 33 disciplinas optativas livres

Total geral (Pedagogia - USP): 173 disciplinas 
Além de oferecer o curso de Pedagogia, a Faculdade de Educação disponibiliza disciplinas pedagógicas para cursos de Licenciatura da Universidade de São Paulo, como é o caso do curso de Letras, outro objeto de nossa pesquisa.

O curso de Letras, pertencente à Faculdade de Filosofia, Letras e Ciências Humanas da USP, inicia-se com um ano básico, destinado a fornecer elementos para a compreensão da linguagem e subsídios para as disciplinas posteriores. Ao final do ano introdutório, o aluno, de acordo com critérios pré-estabelecidos ${ }^{3}$, faz a opção pela área desejada, podendo cursar bacharelado com habilitação simples (numa das seguintes especialidades: Português, Alemão, Árabe, Armênio, Chinês, Espanhol, Francês, Grego, Hebraico, Inglês, Italiano, Japonês, Latim, Russo ou Linguística) ou optar por habilitação dupla, em Português e uma das opções já mencionadas. Também é possível complementar a formação com a Licenciatura em Letras, em período integral. Parte das disciplinas da Licenciatura é oferecida pela própria Faculdade de Filosofia, Letras e Ciências Humanas (FFLCH) e parte pela Faculdade de Educação (FE). Na Licenciatura, além de cumprir as disciplinas obrigatórias, o aluno deve cursar duas optativas: uma da FFLCH e uma da FE ou as duas da FFLCH.

\begin{tabular}{|l|}
\hline \multicolumn{1}{|c|}{ Licenciatura em Letras/Português - USP } \\
\hline Disciplinas obrigatórias: \\
\hline Atividades Acadêmico-Científico-Culturais I \\
\hline Atividades Acadêmico-Científico-Culturais II \\
\hline Atividades Acadêmico-Científico-Culturais III \\
\hline Atividades Acadêmico-Científico-Culturais IV \\
\hline Atividades Acadêmico-Científico-Culturais V \\
\hline Atividades de Estágio (Licenciatura em Letras) \\
\hline Didática (FE) \\
\hline Metodologia do Ensino de Português I (FE) \\
\hline Metodologia do Ensino de Português II (FE) \\
\hline Política e Organização da Educação Básica no Brasil (FE) \\
\hline Total: 10 disciplinas obrigatórias \\
\hline \\
\hline Disciplinas optativas eletivas: \\
\hline A Linguística na Educação Básica (FFLCH) \\
\hline A Psicanálise, Educação e Cultura (FE) \\
\hline A Psicologia Histórico-cultural e a Compreensão do Fenômeno Educativo (FE) \\
\hline Abordagens Críticas e o Ensino da Literatura (FFLCH) \\
\hline
\end{tabular}

\footnotetext{
${ }^{3}$ O aluno define a habilitação pretendida de acordo com sua classificação pela média das notas semestrais em cada disciplina no primeiro ano. Cada habilitação oferece um número limitado de vagas, que são distribuídas prioritariamente por ordem de classificação do aluno - http://www.fflch.usp.br
} 
Aquisição/Aprendizagem do Alemão como Língua Estrangeira (FFLCH)

Aquisição/Aprendizagem do Espanhol como Língua Estrangeira (FFLCH)

Aquisição/Aprendizagem do Francês como Língua Estrangeira (FFLCH)

Diversidade Cultural e Educação:as Literaturas de Língua Portuguesa em Perspectiva (FFLCH)

Ensino de Literatura Brasileira (FFLCH)

Ensino e Aprendizagem da Língua Italiana (FFLCH)

Introdução aos Estudos da Educação: Enfoque Filosófico (FE)

Introdução aos Estudos da Educação: Enfoque Histórico (FE)

Introdução aos Estudos da Educação: Enfoque Sociológico (FE)

Língua, Discurso e Ensino (FFLCH)

Literatura e Educação (FFLCH)

Literatura Portuguesa: Ensino-Aprendizagem (FFLCH)

Práticas Escolares, Contemporaneidade e Processos de Subjetivação (FE)

Práticas Escolares, Diversidade, Subjetividade (FE)

Psicologia da Educação : Uma Abordagem Psicossocial do Cotidiano Escolar (FE)

Total: 19 disciplinas optativas livres

Total geral: 29 disciplinas

O Bacharelado em Letras com habilitação em Português tem duração mínima de oito semestres (incluindo o ciclo básico), com carga horária total de 3.360 horas. A formação também em Licenciatura exige mais 480 horas. No Bacharelado matutino, foco de nosso estudo, são oferecidas 29 disciplinas obrigatórias, 40 optativas eletivas e 57 optativas livres, num total de 126, das quais o aluno deve cursar 87 créditos de disciplinas obrigatórias e 90 de optativas eletivas e/ou livres.

\begin{tabular}{|l|}
\hline \multicolumn{1}{|c|}{ Bacharelado em Letras/Português - USP } \\
\hline Disciplinas obrigatórias: \\
\hline Introdução aos Estudos Clássicos I \\
\hline Elementos de Linguística I \\
\hline Elementos de Linguística II \\
\hline Filologia Portuguesa \\
\hline Filologia Românica I \\
\hline Fonética e Fonologia do Português \\
\hline Fonologia: Descrição e Análise \\
\hline Introdução ao Estudo da Língua Portuguesa I \\
\hline Introdução ao Estudo da Língua Portuguesa II \\
\hline Introdução ao Latim I \\
\hline Introdução ao Latim II \\
\hline Introdução aos Estudos Clássicos II \\
\hline Introdução aos Estudos Comparados de Literatura de Língua Portuguesa I \\
\hline Introdução aos Estudos Literários I \\
\hline Introdução aos Estudos Literários II \\
\hline
\end{tabular}


Língua Grega I

Literatura Brasileira I

Literatura Brasileira II

Literatura Brasileira III

Literatura Brasileira IV

Literatura Infantil e Juvenil: Linguagens do Imaginário I

Literatura Portuguesa I

Literatura Portuguesa II

Literatura Portuguesa III

Literatura Portuguesa IV

Literaturas Africanas de Língua Portuguesa I

Morfologia do Português I

Sintaxe do Português I

Teorias do Texto - Enunciação, Discurso e Texto

Total: 29 disciplinas obrigatórias

\section{Disciplinas optativas eletivas:}

Língua Grega II

Correntes Críticas I

Correntes Críticas II

Diálogo Platônico

Épica Grega: Homero

Filologia Românica II

Historiografia Grega

Introdução aos Estudos Comparados de Literatura de Língua Portuguesa II

Lexicologia e Lexicografia

Língua Grega III

Língua Grega IV

Língua Latina III

Língua Latina IV

Língua Não-indoeuropeia I

Língua Não-indoeuropeia II

Lírica Grega

Literatura Comparada I

Literatura Comparada II

Literatura e Educação

Literatura Infantil e Juvenil: Linguagens do Imaginário II

Literatura Latina: Elegia

Literatura Latina: Épica

Literatura Latina: Epistolografia ou Sátira

Literatura Latina: História da Literatura ou Historiografia

Literatura Latina: Lírica

Literatura Latina: Teatro

Literaturas Africanas de Língua Portuguesa II

Literaturas Africanas de Língua Portuguesa III 
Literaturas Africanas de Língua Portuguesa IV

Morfologia

Poemas Hesiódicos

Pragmática

Psicolinguística

Semântica

Sintaxe: Fundamentos da Análise e Descrição Sintáticas

Sociolinguística Variacionista

Teatro Grego

Teoria e Análise de Textos: Semiótica Narrativa e Discursiva

Teoria Literária I

Teoria Literária II

Total: 40 disciplinas optativas eletivas

\section{Disciplinas optativas livres:}

A Música do Brasil Independente

Aspectos da Literatura Grega I

Aspectos da Literatura Grega II

Aspectos de Etnolinguística: Representações Simbólicas e Tabus da Linguagem

Conceitos de Poética Latina

Conceitos de Retórica Latina

Cultura Sânscrita Bramânica

Cultura Sânscrita Védica

Do Português Arcaico ao Português Brasileiro

Estilística

Filologia Portuguesa: Edição de Documentos Brasileiros

Filologia Românica III

Filologia Românica IV

Filologia Românica: O catalão I

Filologia Românica: O Catalão II

Filologia Românica: O Galego I

Filologia Românica: O Galego II

Introdução ao Sânscrito I

Introdução ao Sânscrito II

Introdução ao Sânscrito III

Introdução ao Sânscrito IV

Introdução ao Sânscrito V

Introdução ao Sânscrito VI

Introdução ao Sânscrito VII

Introdução aos Estudos Comparados de Literatura de Língua Portuguesa III

Introdução aos Estudos Comparados de Literatura de Língua Portuguesa IV

Introdução aos Estudos das Línguas Crioulas de Base Portuguesa e do Português na África

Introdução aos Estudos do Léxico

Introdução aos Estudos do Português para Falantes de Outras Línguas

L'amors de Troubadours na România Medieval 
Leitura e Produção de Textos I

Leitura e Produção de Textos II

Literatura Brasileira V

Literatura Brasileira VI

Literatura Infantil e Juvenil: Linguagens do Imaginário III

Literatura Infantil e Juvenil: Linguagens do Imaginário IV

Literatura Portuguesa V

Literatura Portuguesa VI

Literatura Sânscrita Clássica/Poesia

Literatura Sânscrita Clássica/Teatro

Literatura Sânscrita Clássica/Narrativa

Literatura Sânscrita Épica

Literaturas Africanas de Língua Portuguesa V

Literaturas Africanas de Língua Portuguesa VI

Metodologia e Prática do Comentário Linguístico de Textos

Morfologia do Português II

Os Americanismos Léxicos nos Primeiros Cronistas Americanos

Sintaxe do Português II

Técnicas Instrumentais de Interpretação e Análise Prosódica na Produção de Textos da

Língua Portuguesa

Teorias da Linguagem na Índia Antiga

Tópicos em Teorias do Texto

Toponímia Geral e do Brasil I

Toponímia Geral e do Brasil II

Tupi I

Tupi II

Tupi III

Tupi IV

Total: 57 disciplinas optativas livres

Total geral: 126 disciplinas

\section{Objetivos da pesquisa}

Ao estabelecer os objetivos, procuramos refletir sobre o que seria realmente factível levando em consideração o tempo e os recursos disponíveis. Como se trata de uma pesquisa de Mestrado, com tempo restrito para ser finalizada, desenvolvemos o planejamento de todas as etapas em função dessas questões, evitando correr o risco de ampliar o leque de possibilidades e não conseguir cumprir o proposto. Os objetivos empíricos do trabalho estão concentrados em pontos centrais: 
- Investigar a formação do professor para a inter-relação comunicação/educação no âmbito da educação formal;

- Verificar como o futuro professor entende a relação entre comunicação e educação e como pretende traduzir essa relação em suas práticas de ensino;

- Verificar se o professor que está saindo da universidade tem uma relação de proximidade com a mídia e os recursos tecnológicos.

- Identificar os hábitos midiáticos do profissional;

A contribuição social também é um dos objetivos principais do trabalho. Queremos desenvolver um estudo que não fique apenas "na estante da biblioteca", mas que seja capaz de gerar debates, desdobramentos e assim contribuir para uma melhor formação do professor. Trata-se de uma pesquisa qualitativa, não sendo, portanto, de representatividade estatística, passível de generalizações, porém acreditamos que é significativa, pois pode mostrar tendências de comportamento e verificar como ocorrem os processos em determinados grupos, o que representa os primeiros passos para trazer o assunto à tona e dar início a possíveis mudanças. 


\section{CAPÍTULO II - Quadro teórico de referência: relação comunicação/educação}

Discutiremos, como fio-condutor deste trabalho, a inter-relação comunicação/ educação com o objetivo de reconhecer que temos atualmente novas formas de produzir, circular e receber o conhecimento, o qual está espalhado em lugares sóciotécnicos e não apenas na escola. Admitir a existência de um diálogo próximo entre comunicação e educação é, como destaca Adilson Citelli, "constatar que não se aprende/apreende mais como ocorria em tempos dominados por ciclos do conhecimento constituídos, apenas, em torno da oralidade primária ou da escrita" (CITELLI, 2006: 163). As possibilidades trazidas pelas novas tecnologias e pelos meios de comunicação alteraram as formas de produção dos sentidos, o que se estende à escola, cabendo a ela compreender esses fenômenos e considerá-los ao desenvolver suas práticas educativas. Em nossa reflexão, buscaremos formas de promover a integração entre os campos da comunicação e da educação, sempre tendo em mente que todo o processo de transmissão de mensagens depende de elementos de mediação e que o sentido se constrói nas relações, não sendo preliminar ou unidirecional.

Para compreendermos a relação existente entre comunicação e educação, é importante que adotemos uma visão ampliada sobre o campo da comunicação. Compartilhamos com Roseli Figaro (2008) o entendimento desse campo como "multi, trans e interdisciplinar". Segundo a autora, as discussões sobre a comunicação apresentam basicamente duas tendências: uma que considera o campo sob a perspectiva das práticas e técnicas, e outra que busca compreender o processo de comunicação, "envolvendo as interações humanas, as sociabilidades, as técnicas e práticas, as tecnologias e as novas sensibilidades, a comunicação como educação, como poder e desenvolvimento dos grupos sociais" (FIGARO, 2008: 17). É com essa segunda abordagem que estamos trabalhando, sempre considerando a comunicação sob uma perspectiva dialógica, enquanto processo que não se resume a transmissão de informações. Importante diferenciarmos, aliás, informação de comunicação. Dominique Wolton destaca que esses termos não são sinônimos, pois a informação está sempre ligada à mensagem, independentemente de qual seja o suporte, enquanto que a comunicação envolve um processo muito mais complexo, pois depende do encontro com o receptor.

"Informar é produzir e distribuir mensagens o mais livremente possível. A comunicação, em contrapartida, supõe um processo de apropriação. É uma relação entre o emissor, a mensagem e o receptor. Comunicar, portanto, não é apenas produzir informação e distribuílla, é também estar atento às condições em que o 
receptor a recebe, aceita, recusa, remodela, em função de seu horizonte cultural, político e filosófico, e como responde a ela." (WOLTON, 2006: 16).

Segundo o autor, a comunicação envolve negociação, pois o receptor tem a liberdade de aceitar, repensar, rejeitar e negociar a mensagem recebida. "Na realidade, o receptor complica tudo, raramente está onde o esperamos, compreendendo, em geral, algo diferente do que lhe dizemos ou gostaríamos que compreendesse pelo som, pela imagem, pelo texto ou pelo dado" (WOLTON, 2006: 32). E essa capacidade de negociação do receptor é o grande trunfo da comunicação, já que relativiza o poder do emissor e a eficiência da mensagem. O processo comunicacional envolve muito mais que um sistema de troca de informações, "diz respeito às relações entre sujeitos e subjetividades, numa sociedade complexa e tecnológica" (FIGARO, 2008[A]: 112). Nesse processo, os meios de comunicação, sobretudo aqueles ancorados nas novas tecnologias, têm um papel estratégico, de reconfiguradores sociais, "são copartícipes privilegiados na configuração de novas sociabilidades, sensibilidades, conceitos de produção, circulação e consumo de produtos simbólicos" (CITELLI, 2006: 28). No entanto, embora tenham uma posição privilegiada no fluxo comunicacional, os meios não são determinantes desse processo.

\section{Jogo dos sentidos}

A comunicação, considerada a partir da perspectiva com a qual estamos trabalhando, como lugar de entrecruzamentos discursivos, depende de campos de constituição de sentidos, os quais não são predeterminados, pois estão sujeitos a uma série de mediações. E um dos mediadores por excelência do processo comunicativo é a linguagem. A partir dos estudos da linguagem, podemos compreender como os sentidos são construídos, desconstruídos e reconstruídos, e a partir daí discutir a dimensão estratégica dos meios de comunicação. Nossa intenção não é estudar a estrutura da língua, mas compreender os mecanismos discursivos que levam à significação.

Compartilhamos com Adilson Citelli o entendimento de que a construção de sentidos se faz no âmbito do jogo dialogal, a partir de trocas, fluxos e negociações entre interlocutores. "O sentido não é, neste caso, categoria abstrata, pré-dada, mas decorre de mediações que combinam múltiplos e variados elementos de natureza cultural, social, etária etc" (CITELLI, 2006: 14). A circulação discursiva depende tanto do emissor 
quanto do receptor, e não devemos isolar esses polos como unidades autônomas de significações.

"Vale dizer, a questão propriamente da produção do sentido passa a ser localizada na metáfora da travessia: nessa perspectiva não há atracadouros seguros, mas instâncias de passagem do 'entre' - aquele espaço intervalar que permite apreender a natureza dos procedimentos dialógicos e interativos (CITELLI, 2004: $54) "$

O uso do termo "dialógico" é adotado pelo autor pelo viés bakhtiniano, não estando relacionado meramente a uma técnica conversacional ou à possibilidade de entendimento, mas a uma instância que marca a construção dos sentidos, a linguagem. A natureza dialógica da linguagem implica em cadeias interlocutivas que vão se refazendo num movimento social complexo, não existindo um precedente zero: toda linguagem deriva de outras: “... os mais variados tipos de signos e seus arranjos vivem em permanentes deslocamentos (retro)alimentando-se nas sequências intertextuais/ interdiscursivas que funcionam em seus nexos históricos e sociais como fontes dialogicamente produtoras de sentidos" (CITELLI, 2006: 55).

Nesse movimento dialógico, o sentido não se define apenas na capacidade nomeadora da linguagem, pois depende de conexão com os cruzamentos históricos e sociais. Aqui é importante destacarmos a contribuição do filósofo Ludwing Wittgenstein, pertencente à tradição pragmática da filosofia analítica inglesa, com o objetivo apenas de organizar o conceito de produção de sentidos com o qual estamos trabalhando. O filósofo supera a visão metafísica e nominalista da linguagem para adotar a ideia do jogo, que condiz com nossa proposta de circulação discursiva entre emissor e receptor. Para Wittgenstein, o sentido não se constitui “cá”, na capacidade puramente nomeadora das palavras, nem "lá", no plano da natureza, mas sim no jogo entre o lugar da linguagem e a ordem do mundo. As significações nascem no movimento entre o "cá" e o "lá", em função de contextos e do uso da linguagem. "Todo signo, sozinho, parece morto. O que lhe confere vida? - Ele está vivo no uso" (WITTGENSTEIN, 2005: 173). Para o filósofo, a linguagem não é um mecanismo fixo, fechado; ela está em permanente mudança e comporta inúmeras espécies diferentes de emprego dos signos.

"E essa variedade não é algo fixo, dado de uma vez por todas; mas, podemos dizer, novos tipos de linguagem, novos jogos de linguagem surgem, outros envelhecem e são esquecidos (...). A expressão 'jogo de linguagem' deve salientar aqui que falar uma língua é parte de uma atividade ou de uma forma de vida." (WITTGENSTEIN, 2005: 27) 
O conceito de Wittgenstein de jogo de linguagem é plural: há vários jogos de linguagem se movimentando, e não apenas um. Aliás, o filósofo defende que a própria língua apresenta inúmeras variações, que seriam as sublinguagens. Elas permitem a criação de consensos comunicacionais, ou seja, a possibilidade de transacionar palavras, ideias, conceitos. Para o filósofo, o consenso não é permanente, mas sim um equilíbrio tênue, que pode se abalar a qualquer momento. No consenso, as condições de circulação estão dadas, permitindo a entrada em determinada comunidade de linguagem. Depois, lá dentro, há desequilíbrio de compreensões, ideias. O consenso seria, portanto, provisório. Ao se referir a Wittgenstein, Adilson Citelli destaca que as redes significantes não são compostas por toques mágicos entre os usuários de sistemas de linguagens, mas dependem de interações contextuais decorrentes do encontro de vozes existentes na produção e na recepção. “... o texto que escrevemos, o conceito que firmamos, são de algum modo resultados de apropriações, recolhas, fusões, recriações, reinvenções e derivações de vozes dispersas na ordem do mundo" (CITELLI, 2006: 34). Consequentemente, os significados estão em constante renovação, sendo permanentemente construídos, desconstruídos e reconstruídos.

A linguagem possui, portanto, as marcas da vida social. É nesse espaço dialogal entre o "cá" e o "lá" que os signos transitam a partir não só da experiência individual, mas também das marcas históricas, coletivas da sociedade. A linguagem reside no terreno das interações sociais, o que nos leva a Mikhail Bakhtin, teórico russo cujos conceitos trazem importantes contribuições para nosso esforço de compreender a produção de sentidos. Comecemos pelo conceito de signo, fundamental para que ocorra a compreensão das mensagens. Segundo Bakhtin, tudo o que é ideológico é um signo, possui um significado e remete a algo fora de si mesmo. O corpo físico não é um signo, mas pode converter-se em tal na medida que passa a refletir e refratar uma outra realidade:

"Um signo não existe apenas como parte de uma realidade; ele também reflete e refrata uma outra. Ele pode distorcer essa realidade, ser-lhe fiel, ou apreendê-la de um ponto de vista específico, etc. Todo signo está sujeito aos critérios de avaliação ideológica (isto é: se é verdadeiro, falso, correto, justificado, bom, etc.)."(BAKHTIN, 1992: 32)

O mesmo acontece com um instrumento de produção ou um produto de consumo: ele pode ter um sentido ideológico, mas não é, sozinho, signo. Portanto, paralelamente ao universo natural e material, existe um outro universo: “... ao lado dos fenômenos 
naturais, do material tecnológico e dos artigos de consumo, existe um universo particular, o universo dos signos" (BAKHTIN, 1992: 32).

De acordo com Bakhtin, é na linguagem que a comunicação social aparece de maneira mais clara, pois a palavra tem a completa função de signo, ela é o modo mais puro de relação social:

"A palavra é o fenômeno ideológico por excelência. A realidade toda da palavra é absorvida por sua função de signo. A palavra não comporta nada que não esteja ligado a essa função, nada que não tenha sido gerado por ela. A palavra é o modo mais puro e sensível de relação social." (BAKHTIN, 1992: 36)

Além disso, a palavra é um signo neutro: "A palavra (...) é neutra em relação a qualquer função ideológica específica. Pode preencher qualquer espécie de função ideológica: estética, científica, moral, religiosa” (BAKHTIN, 1992: 37).

Bakhtin afirma que a evolução social é resultado de um processo dialético, que envolve diferentes esferas que se influenciam reciprocamente. O processo de evolução procede da infraestrutura (da realidade cotidiana) e vai tomar forma nas superestruturas, formalizando ideologias. Essas, por sua vez, voltam a influenciar a infraestrutura, provocando mudanças. E o indicador mais sensível das transformações sociais é a palavra, capaz de registrar todas as fases dessas mudanças. É através principalmente da palavra que se exterioriza a psicologia do corpo social, ou seja, o meio ambiente inicial dos atos de fala de toda espécie. Ela se manifesta nos diversos aspectos da enunciação sob a forma de diferentes modos de discurso, interiores ou exteriores.

“As palavras são tecidas a partir de uma multidão de fios ideológicos e servem de trama a todas as relações sociais em todos os domínios. É portanto claro que a palavra será sempre o indicador mais sensível de todas as transformações sociais, mesmo daquelas que apenas despontam, que ainda não tomaram forma, que ainda não abriram caminho para sistemas ideológicos estruturados e bem formados." (BAKHTIN, 1992: 41)

O pensador destaca que todo signo é resultado de um consenso formado entre indivíduos socialmente organizados durante um processo de interação: "Razão pela qual as formas do signo são condicionadas tanto pela organização social de tais indivíduos como pelas condições em que a interação acontece" (BAKHTIN, 1992: 44). Porém, o signo ideológico, além de ser marcado pelo meio social, possui um conteúdo, ao qual é atribuído um índice de valor. O corpo social, quando volta a atenção a um grupo de objetos particulares e limitados, está fornecendo um valor particular a esse grupo de objetos, que dará origem aos signos, desencadeando uma reação semiótico-ideológica. 
No entanto, para que isso aconteça, esses objetos precisam estar ligados à realidade do grupo social, às condições sócioeconômicas dele. Um objeto só vira signo quando adquire um valor social. Esse valor chega à consciência individual e parece fazer parte do indivíduo, porém, na verdade, a fonte do valor não se encontra na consciência individual. Ela tem uma natureza interindividual.

Esse valor pode variar de acordo com as classes sociais. Ainda que pertencendo à mesma comunidade semiótica, indivíduos de diferentes classes sociais darão valores contraditórios ao signo ideológico.

"Classe social e comunidade semiótica não se confundem. Pelo segundo termo entendemos a comunidade que utiliza um único e mesmo código ideológico de comunicação. Assim, as classes sociais diferentes servem-se de uma só e mesma língua. Consequentemente, em todo signo ideológico confrontam-se índices de valor contraditórios. O signo se torna a arena onde se desenvolve a luta de classes." (BAKHTIN, 1992: 46)

E é a partir dessa luta que o signo evolui; sem as tensões do embate social, o signo se degenera, transforma-se em alegoria. O signo ideológico vivo tem um caráter dúbio, contraditório, mas que só se mostra nos momentos de crise social e comoção revolucionária. Do contrário, a ideologia dominante tende a não revelar a face oculta do signo, de forma a manter o cenário estabelecido.

Bahktin acredita que os conceitos sociais são transmitidos através da linguagem. Para o teórico, toda atividade mental está ligada à orientação social, fazendo com que a palavra, mesmo antes de ser exteriorizada, já esteja carregada de influência social. "O grau de consciência, de clareza, de acabamento formal da atividade mental é diretamente proporcional ao seu grau de orientação social” (BAKHTIN, 1992: 114). Para o pensador, a linguagem traz uma profusão de vozes, sendo, portanto, essencialmente polifônica. A polifonia é o registro do conjunto de vozes que se alinham no discurso, é o eco de cada discurso - os vínculos culturais e históricos. A polifonia abriga a tensão permanente entre vozes.

Como a palavra é resultado da experiência vivida de cada povo, conforme vai sendo usada, vai agregando outros traços ideológicos, que geram uma pluralidade de significados, perceptíveis apenas na enunciação, que, segundo Bakhtin, é resultado da interação de dois indivíduos socialmente organizados, cuja ligação se dá através da palavra. É ela que faz a ponte entre o locutor e o interlocutor, podendo variar de acordo com o grupo social a que os dois pertencem, a hierarquia existente, o grau de intimidade etc. Mesmo que a palavra, materializada como signo, parta do indivíduo, ela é 
determinada pelas relações sociais, pois a situação social mais imediata é que determina a estrutura da enunciação.

Segundo Bakhtin, a consciência só tem força social e constitui um fato objetivo quando se realiza num material determinado, como a palavra e o gesto. Ela é parte do ser, mas, quando é objetivada socialmente, torna-se capaz de influenciar as bases econômicas da vida social. É o meio social que organiza a enunciação, inclusive a individual: "O centro organizador de toda enunciação, de toda expressão, não é interior, mas exterior: está situado no meio social que envolve o indivíduo" (BAKHTIN, 1992: 121). E é através da enunciação que se realiza a interação verbal. A enunciação é parte de uma corrente de comunicação verbal ininterrupta, que está sempre ligada a outros tipos de comunicação, os quais representam situações concretas. E é nessa comunicação verbal concreta que a língua vive e evolui:
"A verdadeira substância da língua não é constituída por um sistema abstrato de formas linguísticas nem pela anunciação monológica isolada, nem pelo ato psicofisiológico de sua produção, mas pelo fenômeno social da interação verbal, realizada através da enunciação ou das enunciações. A interação verbal constitui assim a realidade fundamental da língua." (BAKHTIN, 1992: 123)

A leitura que fazemos de Bakhtin nos remete mais uma vez àquele espaço dialogal em que se formam as significações. O intervalo social em que as diferentes vozes se tensionam é que permite a constituição de campos de sentido. A linguagem, com sua dialogicidade interna, possui uma natureza interlocutiva, só existindo nas interações sociais. Dessa forma, transportando a visão bakhtiniana para os fluxos comunicativos que estamos estudando, não podemos isolar os polos da emissão e da recepção como unidades autônomas de significação. O componente dialógico e as interações signosujeito-mundo nos oferecem a possibilidade de uma compreensão mais ampla da comunicação na sociedade contemporânea, especialmente do papel dos meios de comunicação, pois nos abrem a perspectiva das mediações como elementos fundamentais no processo de constituição de sentido.

A comunicação de massa sob a ótica das mediações é estudada por Jesús MartínBarbero, que desloca os meios de comunicação do centro da discussão. Esses não são vistos como produtores de sentido único e direcional, capazes de provocar a apatia das massas, tampouco como agências manipulatórias que transformam a cultura em reproduções da indústria cultural. As relações sociais e culturais fazem circular uma variedade de signos e linguagens que irão se confrontar com o discurso dos meios de 
comunicação, ficando a compreensão das mensagens atrelada às diferentes mediações do ser humano.

Os processos comunicacionais são analisados a partir da perspectiva sóciohistórica, num movimento dialógico de construção de sentido. Martín-Barbero acredita que a comunicação não pode ser estudada isoladamente das ciências sociais, estando diretamente ligada a questões que envolvem cultura, política e relações sociais dentro de um cenário marcado por inovações tecnológicas.

"O que a revolução tecnológica introduz em nossas sociedades não é tanto uma quantidade inusitada de novas máquinas, mas, sim, um novo modo de relação entre os processos simbólicos - que constituem o cultural - e as formas de produção e distribuição dos bens e serviços: um novo modo de produzir, confusamente associado a um novo modelo de comunicar, transforma o conhecimento numa força produtiva direta." (MARTÍN-BARBERO, 2006: 54)

O autor esclarece que a mediação tecnológica da comunicação deixa de ser meramente instrumental para tornar-se estrutural: "A tecnologia remete, hoje, não a alguns aparelhos, mas, sim, a novos modos de percepção e de linguagem, a novas sensibilidades e escritas" (MARTÍN-BARBERO, 2006: 54). Na visão de Martín-Barbero, os meios de comunicação e as tecnologias representam mediações em que se constituem os novos modos de interpelação do sujeito, podendo alterar os modos de conhecer das pessoas, o que configura sua dimensão estratégica, sobre a qual falaremos adiante.

Em nossa perspectiva de discussão, ao trazermos reflexões de Wittgenstein, Bakhtin e Martín-Barbero, desejamos elucidar a visão dialógica dos processos comunicacionais, os quais não podem ser analisados a partir de pontos fixos, centrados no emissor, no receptor ou nos próprios meios. A compreensão dos fenômenos do campo da comunicação está diretamente ligada ao entendimento de que o sentido se faz no intervalo cortado por sucessivas instâncias mediativas e dialógicas, e que, nesse movimento, um dos polos pode se destacar momentaneamente, ora prevalecendo a vontade do emissor, ora a capacidade de resposta do receptor e assim sucessivamente. A força da mensagem depende de um conjunto de significações que se estabelece no jogo entre as partes e no qual os elementos mediadores têm papel decisivo.

\section{A condição comunicativa contemporânea}

$\mathrm{Na}$ visão de Guillermo Orozco Gómez, a sociedade contemporânea tem duas grandes tendências crescentes, que se apresentam de maneira paralela e interdependente: a "mediatização" e a "audienciação". O primeiro fenômeno é resultado 
do expansivo protagonismo dos meios de comunicação e das tecnologias de informação. Orozco enfatiza que um fator distintivo das sociedades atuais em relação às anteriores é a dependência mediática múltipla, que envolve aspectos cognitivos, emocionais e práticos. Para o autor, é impossível viver alheio aos meios: "No es posible sustraerse de los medios, y los que lo hacen, o son forzados a hacerlo, afrontan incalculables costos por su exclusión" (OROZCO, 2001: 20). Maria da Graça Setton também destaca que não é mais possível ignorar a instituição midiática, a qual nos rodeia inexoravelmente. "E, nessa qualidade, ressalto sua importância como instância produtora de referenciais identitários e sobretudo como instância difusora de categorias do pensamento que moldam, em grande parte, as representações que se tem da realidade" (SETTON, 2004: 69). A tendência da mediatização desafia a vida cotidiana em todos os aspectos, do individual ao social, do privado ao público, tornando o fenômeno irreversível e imprescindível para as relações sociais. No entanto, ocorre em condições desiguais de poder, guiada por decisões políticas e econômicas. Orozco cita como exemplo a televisão, que é caracterizada de maneira particular em cada país, resultado das decisões que definiram seu desenvolvimento e direcionamento. Para o autor, essa caracterização particular do meio, variando de país a país, indica que ele sempre pode ser de outra maneira, porém Orozco propõe refletirmos sobre como usar o que temos, o que nos é oferecido pelos meios, de maneira inteligente, produtiva, crítica e independente, que contribua para o desenvolvimento das audiências, as quais constituem a segunda tendência da sociedade contemporânea, a "audienciação".

Esse fenômeno é resultado da crescente centralização dos meios como referentes do sujeito social, que passa cada vez mais a se reconhecer, se relacionar e experimentar sensações e emoções através dos meios.

"Una de las experiencias más 'vitales' y definitorias de los sujetos sociales contemporáneos, nos guste o no, son justamente sus televidencias (y demás interacciones mediáticas: escuchas, lecturas, cinevidencias, escenovidencias y navegaciones ciberinformáticas)." (OROZCO, 2001: 21)

As interações do sujeito social, na condição de audiência múltipla, com o entorno e com os acontecimentos são mediadas pelos meios, bem como grande parte de suas vivências. A mediação é entendida por Orozco como um processo estruturante que configura e orienta a interação das audiências, as quais passam a dar sentido aos referentes mediáticos. 
O autor esclarece que, na origem do termo, audiência está ligada ao universo jurídico e indica receber e emitir informações, porém, no caso dos meios tradicionais, cujo representante maior é a televisão, o significado mudou para uma via de mão única: receber a informação. Audiência tornou-se sinônimo de receptor passivo, "de un conglomerado de espectadores estáticos o pasivos, cuya voz no es esperada y en todo caso tampoco escuchada, resaltándose sólo su acción de recibir, de recepción" (OROZCO, 2001: 22). No entanto, mesmo na condição de receptor, o sujeito interage com o meio, negocia os sentidos, sendo, portanto, ativo.

Com a introdução dos novos meios de comunicação e das tecnologias de informação, em especial da internet, o termo audiência pode recuperar sua origem: receber e emitir informações. A interatividade oferecida pelas novas telas (termo usado pelo autor para designar os novos aparatos tecnológicos, como o computador e o celular) permite que o receptor torne-se também produtor, deixando de ser considerado apenas audiência (no sentido deturpado do termo) e passando a ser usuário, termo que prevê um intercâmbio ativo com os meios, uma produção comunicativa. A interação deixa de ser apenas simbólica, possibilitando que as audiências sejam criadoras de seus próprios referentes, e não somente ressignificadoras dos referentes transmitidos pelos meios.

“... la interactividad que permiten las nuevas pantallas transciende la mera interacción simbólica con ellas, para situar a las audiencias, en tanto que se cumplan otras condiciones de accesibilidad y cultura digital, como posibles creadoras de sus proprios referentes, no sólo como re-creadoras simbólicas de significados o interpretaciones de los referentes producidos y emitidos por otros desde esas pantallas." (OROZCO, 2009: 3)

Essa é a condição comunicativa contemporânea: o trânsito do receptor ao receptor-emissor, propiciado pela convergência tecnológica, que multiplica a combinação de formatos, linguagens e estéticas nas telas, criando novas possibilidades de interação comunicativa às audiências.

Orozco chama de "nova produção cultural" o produto do intercâmbio entre as novas telas e as audiências e os usuários. O pesquisador destaca que as diferentes audiovisualidades em circulação atualmente constituem os elementos com que se constroem as ideias e representações daquilo que é veiculado e a posição do sujeito frente a elas. "Dicho de otra manera, cada vez más los referentes claves del intercambio social contemporáneo son productos audiovisuales, mediados y tecnificados a los cuales se accede desde alguna pantalla y suporte tecnológico" (OROZCO, 2009: 6). 
Orozco ressalta, no entanto, que a nova produção cultural não parte do zero; ela vem de um contexto cultural anterior, formado pelos meios tradicionais, porém não se manifesta através desses canais clássicos, já que reúne referentes e linguagens diversificados. Em geral, a materialização da produção cultural ocorre nas próprias telas de onde partiram, mas o conteúdo varia de acordo com o cenário em que foi produzido e carrega resíduos de produções culturais anteriores. Portanto, muito do que a convergência tecnológica possibilita não é necessariamente inovador nem determinante de uma produção cultural distinta. $\mathrm{O}$ pensador enfatiza que há potencial para tanto, porém isso não acontece automaticamente, já que exige preparação para as novas alfabetizações geradas pelos novos meios e tecnologias.

“... las nuevas alfabetizaciones, que de hecho tienen lugar aunque de manera fortuita o no consciente, demandan con urgencia de 'nuevas educaciones', entendidas como otras estrategias para ubicar de manera más adecuada a todos en este intercambio múltiple, creciente y a veces caótico en el que nos encontramos." (OROZCO, 2009: 7)

Delia Crovi afirma que vivemos em uma sociedade da informação e do conhecimento (SIC) em construção, ou seja, uma sociedade atravessada por processos comunicativos em todas as suas atividades (indústria, entretenimento, educação, organização, serviços, comércio etc). "La SIC se presenta así como una sociedad cuyo capital básico es la inteligencia colectiva y la información, distribuida en todos os lados, continuamente valorizada y puesta en sinergia en tiempo real" (CROVI, 2006: 46). A autora enfatiza, no entanto, que os conceitos de informação e conhecimento não podem ser equiparados, pois, embora ambos tenham uma dimensão social e comunicativa, diferenciam-se porque a informação é a matéria-prima do conhecimento. A informação é o "núcleo duro", o dado que pode ser transmitido em mensagens de formas diversas. Já o conhecimento implica um processo muito mais complexo, "en el cual se percibe, recuerda aprende, imagina, razona, discurre, especula, reorganiza" (CROVI, 2006: 51). A autora destaca que a tecnologia, sozinha, é incapaz de gerar as mudanças sociais a que estamos assistindo nos últimos anos, afastando a ideia de um determinismo tecnológico e propondo refletir sobre as matizes e variantes específicas da sociedade da informação e do conhecimento nos diferentes países, a qual responde a dinâmicas sociais particulares. “... no basta contar con infraestructura tecnológica o tener capacidad para integrarse a la economía global, como sostienen las grandes potencias mundiales y los organismos internacionales encargados de promover las SIC" (CROVI, 2006: 23). Por isso, segundo a pesquisadora, a chamada brecha digital é uma parte do 
problema, já que as discussões sobre o tema mostram-se limitadas à questão da infraestrutura, deixando de lado os condicionantes culturais, educativos e econômicos do acesso.
"La lectura de este problema se há centrado en una perspectiva de determinimos tecnológico que há llevado a subestimar el problema o responder a él de manera limitada (...). Al mismo tiempo, este determinismo tecnológico pocas veces vá acompañado de la voluntad política de brindar a los ciudadanos una igualdad de oportunidades que haga de las TIC [Tecnologías de la Información y Comunicación] instrumentos de participación política y ciudadana." (CROVI, 2006: 23)

Para Crovi, brecha digital nada mais é que um outro modo, próprio da sociedade da informação e do conhecimento, de denominar as diferenças entre ricos e pobres. $\mathrm{O}$ desafio, portanto, é o mesmo já enfrentado por propostas de desenvolvimento anteriores. Martín-Barbero também enfatiza que o problema não ocorre em função das tecnologias, mas sim do próprio modelo de sociedade em que estamos inseridos. "La 'brecha' digital es en realidad una brecha social, esto es, no remite a un mero efecto de la tecnología digital sino a una organización de la sociedad que impide a la mayoria acceder y apropriarse tanto física como económica e mentalmente de las TIC" (MARTÍN-BARBERO, 2008: 2). Para o autor, a técnica é o âmbito de criatividade humana, e não apenas de dominação; tudo depende do uso que se faz dela.

Mesmo que a sociedade da informação e do conhecimento tenha dinâmicas particulares em cada país, Crovi lembra que se trata de um processo em construção, porém ao mesmo tempo irreversível. Segundo a autora, essa afirmação se apoia em três argumentos básicos: "la persistencia del modelo neoliberal; el discurso dominante de las nacionales, que apoya y promueve la existencia de la SIC; y el proprio desarollo tecnológico que impone un distanciamiento entre países y personas, en la medida en que algunos pueden actuarlizarse siguiendo este desarrollo vertiginoso, y otros no" (CROVI, 2006: 24). O desenvolvimento específico da SIC em cada país se articula com os processos comunicativos em todos os seus níveis, nos quais se manifesta uma clara tendência à mediatização tecnológica, como já apontado por Orozco. Crovi explica ainda que, embora existam grandes distâncias entre os países e entre os próprios indivíduos no que diz respeito ao acesso às tecnologias de informação e comunicação (TIC), pelo menos uma parcela da população de todos os países já integrou as TIC às suas atividades. 


\section{A educação e o modelo escolar tradicional}

Dentro desse cenário de inovação tecnológica e produção comunicativa, entendemos a escola como espaço mediativo, considerando-a como instituição marcada por cruzamentos discursivos trazidos pelas novas linguagens em circulação e pelas transformações decorrentes da sociedade contemporânea, sejam sociais, culturais, científicas ou tecnológicas. Compartilhamos a visão de Mírian Grinspun acerca da educação como prática social, "portanto, uma prática que se realiza num tempo histórico determinado, com características ideológicas específicas e voltadas para a subjetividade" (GRINSPUM, 2002: 31). Ao recuperar a etimologia da palavra educação, a autora distingue dois vocábulos latinos que dão origem à expressão: educare e educere. O primeiro tem o sentido de orientar, nutrir, numa contribuição externa ao indivíduo; já o segundo busca promover de dentro para fora as potencialidades que o sujeito possui. Grinspun destaca que, em geral, a escola trabalha com o conceito de educare ao estabelecer currículos e normas para o ensino padronizado. Já o educere não tem a mesma presença, já que se volta para o indivíduo em suas capacidades próprias de formação, porém, para a autora, os dois conceitos deveriam estar unidos no processo educacional. "Acho que poderíamos dizer - de uma maneira muito generalizada - que temos um sentido externo que deve caminhar junto ao sentido interno do próprio ato de educar-se" (GRINSPUM, 2002: 33).

A educação que une o educare e o educere poderia ser um caminho para a real formação, no sentido definido por Willi Bolle, semelhante ao conceito de Bulding alemão, cuja tradução literal não existe em nenhuma outra língua. Formação implica necessariamente um autodesenvolver-se, pois exige independência, liberdade e autonomia, o que não pode ser obtido somente por meio da instrução. O autor ressalta que formação e erudição não se confundem, pelo contrário, o modelo de escola como sinônimo de acumulação de conhecimento, ou educação bancária, como diria Paulo Freire, vai em direção oposta ao conceito de formação: "Estudar ao máximo, encher a cabeça até o limite, para evitar o ato de pensar" (BOLLE, 1997: 13). Essa seria a característica da educação que visa à instrução e não à formação, pois a Bulding seria alheia às preocupações com a profissão e o emprego; o objetivo de formar-se não deveria estar atrelado ao ganha-pão. Bolle, ao retirar essa abordagem de Nietzsche, esclarece que se trata de uma visão idealista, já que é necessário passar pelo crivo da realidade, mas que funciona como uma crítica às instituições educativas que não valorizam a reflexão, a filosofia, a arte. 
O autor explica que o conceito de Bulding é altamente complexo, "com extensa aplicação nos campos da pedagogia, da educação e da cultura, além de ser indispensável nas reflexões sobre o homem e a humanidade, sobre a sociedade e o Estado" (BOLLE, 1997: 14), e foi se afinando ao longo da evolução político-social da Alemanha. O conceito, que até o século XVIII referia-se a uma reprodução por semelhança, ou seja, tinha um sentido de produção exterior, passou então a significar uma construção interior: mental, psíquica e espiritual. E posteriormente ganhou uma função libertadora, capaz de soltar as amarras impostas pela própria educação. O conceito, então, sofreu uma grande ampliação, ultrapassando a noção de "educação" para tomar lugar ao lado dos conceitos de "espírito", "cultura" e "humanidade". "Bulding (...) é o conceito central para todos os que estão empenhados no desenvolvimento físico, psíquico e intelectual do ser humano" (BOLLE, 1997: 18). Em português, a palavra formação é a que mais se aproxima do conceito de Bulding, e é nessa dimensão que se insere o conceito com o qual estamos trabalhando. Formação como liberdade, criatividade, autonomia, e não na dimensão da formatação: formatar, colocar numa fôrma. Embora a palavra formação possa apresentar essa ambiguidade, a utilizamos como sinônimo do primeiro conceito, como um processo de autodesenvolvimento, que envolve sistematização e vivências, num constante movimento entre acumulação (o lugar do dever) e experimentação (o lugar do lúdico).

No modelo escolar tradicional, no entanto, predomina a razão instrumental, fortemente marcada pelo dever e pela acumulação, o que seria equivalente ao educare ("nutrir") mencionado por Mírian Grinspun ou à acumulação bancária (“depositar”) de Paulo Freire. Essa visão cumulativa é resultado da estrutura em que a educação formal está baseada, a qual, segundo Adilson Citelli, conta com três eixos básicos: hierarquia, coerção e exclusão. Os mecanismos de exclusão estão ligados aos conteúdos fixos e à visão linear do desenvolvimento cognitivo, que geram repetência e, consequentemente, evasão escolar. Já os elementos coercitivos tradicionais, como ameaças de reprovação, notas baixas e expulsões, não desapareceram, porém ganharam novas cores e formas, muitas vezes diluídas em discursos que apontam um aparente arrefecer dos conflitos na escola. Usa-se a estratégia do entendimento, da construção de consensos, porém sempre uma das partes é dominante no discurso e protegida pelo aparato burocrático. Uma ação não-coercitiva seria o professor dar voz aos alunos, promovendo a discussão, o debate em sala de aula e, consequentemente, oferecendo a possibilidade de questionar o conhecimento institucionalizado. Porém essa iniciativa esbarra na prática discursiva 
tradicional da escola, baseada no monologismo. A hierarquização, por sua vez, ocorre tanto em termos estruturais quanto de relacionamento. $\mathrm{O}$ acordo burocrático enfatiza a hierarquia organizacional: ministério e secretarias determinam os conteúdos a serem trabalhados; direção e coordenação cobram dos professores o cumprimento desses conteúdos; professores reproduzem o desejo de autoridade nos alunos (relação hierarquizada) por meio de avaliações que visam não necessariamente a um objetivo pedagógico, mas sim, muitas vezes, a mostrar poder e autoridade, afinal, como ressalta Foucault (2007), o poder não está apenas nas macroesferas, mas também nas microesferas. As relações de poder se internalizam nas relações sociais, fazendo com que os sujeitos estejam permanentemente em disputa.

$\mathrm{Na}$ escola, também os conteúdos são hierarquizados. O desenvolvimento cognitivo da criança é medido em termos da hierarquia dos conteúdos, a qual representa um empecilho para a mudança de série ou grau.

"Considerando que o domínio dos assuntos escolhidos como relevantes numa certa área do conhecimento determina o sucesso ou o fracasso no percurso escolar, o aprendiz muda ou não de série na dependência de conseguir operacionalizar raciocínios e informações elencados na progressão hierárquica dos conteúdos." (CITELLI, 2000: 85)

Nessa estrutura, só está apto a continuar quem domina aquele conjunto de conteúdos selecionados hierarquicamente e fora das unidades escolares, mas dentro das estruturas oficiais que os normatizam. Seguindo essa linha de pensamento, Daniel Filmus ressalta que o tipo de saber predominante atualmente nas escolas é fortemente "atomizado, memorístico e enciclopédico. Está profundamente desvinculado da realidade e não ajuda a compreender os processos tecnológicos e sociais que ocorrem fora delas" (FILMUS, 2004: 126). Segundo o autor, a base da formação escolar são dados, datas e fórmulas cujo objetivo é a aprovação em exames, os quais darão acesso a outros exames. O resultado é um ensino repetitivo. Martín-Barbero diz que os educandos fazem "eco" ao conteúdo apresentado, cuja eficiência é medida pelo número de alunos que conseguem reproduzir o que está nos livros, reprimindo o questionamento e a reflexão. A questão da hierarquia, aliás, é um dos principais pontos de diferenciação entre as linguagens escolares, que têm o predomínio do signo verbal, e as linguagens não escolares, em que há dominância dos signos complexos, como acontece na TV e na internet, por exemplo. As linguagens não escolares dispensam a preocupação com a 
distribuição hierárquica dos conteúdos, como acontece no ensino formal, o que, para Jesús Martín-Barbero, abre espaço à criatividade.

Citelli explica que a hierarquização dos conteúdos gera um circuito negativo: a educação assinala aquilo que o livro didático deve dizer, e ele entra com força no sistema, passando a dirigi-lo e repetindo as mesmas fórmulas. Assim, não há espaço para a criação, para a construção partindo da realidade do aluno. O livro didático tornase indispensável ao professor (inclusive o caderno de respostas), sob a justificativa de que segui-lo é essencial para que o estudante passe no vestibular. Diante desse cenário, Citelli afirma que "entendida a extensão da metáfora, o livro didático tornou-se, no âmbito escolar, comunicação de massa" (CITELLI, 2000: 89). O Ministério da Educação compra milhões de exemplares, e há uma espécie de consenso sobre a extrema necessidade do livro didático e as consequências "desastrosas" que a falta dele traria, discurso que certamente alimenta a indústria do livro. Consequentemente, a escola se nutre da linguagem parafrásica, substanciada no livro didático. Oferta-se o igual como se fosse diferente. Assim, o discurso pedagógico da escola, que deveria levar ao pensamento crítico, apenas harmoniza o mesmo discurso. Com isso, enrijecemse os conteúdos programáticos, e o professor torna-se o objeto de seu próprio discurso: “O paradoxo parece forte, mas é real, pois o sujeito é dito por um texto que possui vida própria, independentemente de aparecer sob desenhos e formas diferentes ao longo dos anos em modernizadas edições escolares" (CITELLI, 2000: 91). Não é o professor quem tem a palavra na sala de aula, já que ele se torna instância de reprodução discursiva, submetendo-se ao jogo parafrásico. O docente realmente está no centro da prática didática, e o aluno à margem, mas são os jogos de poder e autoridade que o colocam ali, e não o fato de ser o "dono da palavra”. Dessa forma, a escola não oferece ao educando a possibilidade de questionamento: “... o que continua existindo na sala de aula, grosso modo, é a permanência de práticas discursivas animadas pelo monologismo que preside as relações entre vários níveis da hierarquia educacional: instâncias gerenciais, professores, equipes técnicas, alunos, etc." (CITELLI, 2000: 100). Esse monologismo promove a constante reprodução do discurso dominante, embora muitas vezes mascarado por aparente interação e diálogo. Portanto, até mesmo o discurso escolar trabalha com a vontade de verdade definida por Foucault, ou seja, aquilo que a ordem do discurso quer constituir como verdade, usando, para isso, exclusões e limitações. A formação discursiva na escola está atrelada à formação ideológica dominante. "Todo sistema de educação é uma maneira política de manter ou de 
modificar a apropriação dos discursos, com os saberes e os dizeres que eles trazem consigo" (FOUCAULT, 2007: 44).

As formações discursivas, definidas por Foucault como uma espécie de unidade que tem os seus mecanismos de dizer, determinando tudo aquilo que pode ou não ser dito, explicitam as formações ideológicas, mostrando que as relações entre linguagem e poder são absolutamente próximas. Segundo Foucault, vivemos na sociedade do discurso, que não busca as verdades, mas sim constrói ordens discursivas que podem compor a verdade ou não. No entanto, assim como o sentido não está pronto e acabado, acreditamos que as formações discursivas não são fixas em seus limites, podendo extrapolar fronteiras e "contaminar" umas às outras, já que vivem em tensão. E o educador, muitas vezes, transmite essa tensão: embora atualmente ele seja formado com foco na chamada pedagogia renovada, cujo grande expoente é Paulo Freire, com a proposta de dar voz aos alunos, de não expulsar, de incentivar a progressão continuada, quando está na sala de aula o educador recorre à formação discursiva "tradicional" da escola, com os preceitos de ordem, disciplina, autoridade. É o caso, por exemplo, do que indica uma pesquisa da Organização dos Estados Ibero-americanos e da Fundação SM, realizada no Brasil com 8.773 docentes da educação básica. O estudo "A Qualidade da Educação Sob o Olhar dos Professores" mostra que $83 \%$ dos docentes defendem medidas mais duras em relação ao comportamento dos alunos e 67,4\% acreditam que alunos indisciplinados deveriam ser expulsos ${ }^{4}$.

A visão cumulativa do conhecimento, chamada por Paulo Freire de educação bancária, não condiz com a ideia de uma educação capaz de fazer o sujeito aprender a aprender, tornando-se agente transformador do mundo. Nos termos de Adorno, a educação emancipatória não é a "mera transmissão de conhecimento":

\footnotetext{
"A seguir, e assumindo o risco, gostaria de apresentar a minha concepção inicial de educação. Evidentemente não a assim chamada modelagem de pessoas, porque não temos o direito de modelar pessoas a partir do seu exterior; mas também não a mera transmissão de conhecimentos, cuja característica da coisa morta já foi mais do que destacada, mas a produção de uma consciência verdadeira. Isto seria inclusive da maior importância política." (ADORNO, 1995: 141)
}

Para o pensador frankfurtiano - lembrado geralmente por suas discussões sobre a indústria cultural, mas que também reflete sobre a educação, especialmente como forma de se evitar o retorno da barbárie (nazismo) - a efetiva democracia depende de pessoas

\footnotetext{
${ }^{4}$ Pesquisa divulgada em 25/09/2008 pelo jornal Folha de S. Paulo e reproduzida pela Folha Online.
} 
emancipadas, não apenas enquanto indivíduos, mas principalmente enquanto seres sociais, o que se alcança por meio da educação. Adorno reconhece que um dos papéis da educação é preparar o indivíduo para se orientar no mundo, para se adaptar, porém enfatiza que ela não deve se limitar a produzir "pessoas bem ajustadas", pelo contrário, deve fortalecer a resistência, o questionamento, estimulando a capacidade transformadora do indivíduo consciente:

\begin{abstract}
"A educação seria imponente e ideológica se ignorasse o objetivo de adaptação e não preparasse os homens para se orientarem no mundo. Porém ela seria igualmente questionável se ficasse nisto, produzindo nada além do well adjusted people, pessoas bem ajustadas, em consequência do que a situação existente se impõe precisamente no que tem de pior. Nesses termos, desde o início existe no conceito de educação para a consciência e para a racionalidade uma ambiguidade. Talvez não seja possível superá-la no existente, mas certamente não podemos nos desviar dela." (ADORNO, 1995: 143-144)
\end{abstract}

Na visão de Adorno, o simples repassar de conteúdos limita a educação a instância de adaptação, e não de emancipação. A transferência de conhecimento de que fala Adorno também é discutida por Paulo Freire nos termos de "extensão educativa". O pedagogo brasileiro adota a expressão ao se referir a cursos de capacitação, mas que também pode ser identificada no modelo de educação tradicional: o educador, "dono do saber", estenderia seu saber aos educandos, pertencentes ao "mundo da ignorância", para, assim, "salvá-los". Segundo o autor, essa prática é domesticadora e, portanto, contrária à educação libertadora.

“... educar e educar-se, na prática da liberdade, é tarefa daqueles que sabem que pouco sabem - por isso sabem que sabem algo e que podem assim chegar a saber mais - em diálogo com aqueles que, quase sempre, pensam que nada sabem, para que estes, transformando seu pensar que nada sabem em saber que pouco sabem, possam igualmente saber mais." (FREIRE, 1996: 25)

Aprender é apropriar-se de fato do que foi estudado, sendo capaz de reinventar o conteúdo, aplicá-lo a situações existenciais concretas, fazer inter-relações com outros fatores. Paulo Freire diz que o sujeito que é simplesmente "enchido" por conteúdos, sem que seja desafiado, não aprende. E, para que a educação promova a verdadeira aprendizagem, os papéis de professor e aluno têm que ser revistos: “... é necessário que, na situação educativa, educador e educando assumam o papel de sujeitos cognoscentes mediatizados pelo objeto cognoscível que buscam conhecer" (FREIRE, 1996: 28). Essa reciprocidade no processo educativo remete a comunicação, e não a extensão, pois na comunicação não há sujeitos passivos, há uma troca de significações. "A educação é comunicação, é diálogo, na medida em que não é a transferência de saber, mas um 
encontro de sujeitos interlocutores que buscam a significação dos significados" (FREIRE, 1996: 69). Heloisa Dupas Penteado lembra que, nesse contexto de educação como processo comunicacional, os sujeitos envolvidos na relação pedagógica deixam de ser informativo (professor) e receptivo (aluno) para serem ambos responsivos, trocando experiências e conhecimentos, ensinando e aprendendo ao mesmo tempo. "Nessa perspectiva o processo de ensino/aprendizagem é um processo de partilha consentida, de colaboração, de solidariedade. Nunca um processo de dominação-subordinação. Admite a recusa, o ponto de vista diferente" (PENTEADO, 2001: 19). Com essa postura, o professor evita o autoritarismo, mas sem abrir mão de sua "autoridade" enquanto profissional que vai orientar o processo de ensino-aprendizagem. Professor e aluno ocupam o lugar de sujeitos comunicantes. E, para haver comunicação, é preciso existir um acordo em torno dos signos, com os sujeitos compartilhando um quadro significativo comum. Caso contrário, "não pode haver compreensão entre os sujeitos, o que impossibilita a comunicação" (FREIRE, 1996: 67). É por isso que o universo do educando deve ser trazido para a sala de aula, de forma a criar um sistema simbólico inteligível para o aluno, o que contribui para uma educação "significativa". Tania Maria Speron Porto usa essa expressão para designar o processo educativo no qual o aluno encontra sentido no que faz. "O significativo para os alunos surge e é construído a partir das atividades e experiências destes, dos conhecimentos e iniciativas didáticas dos professores, observando a sistematização lógica dos conteúdos focalizados" (PORTO, 2001: 29). Segundo a autora, quando o ensino/aprendizagem faz sentido para o aluno, acaba se tornando também interessante, e essa construção de sentido certamente está atrelada à experiência comunicacional do estudante com as mídias, pois "os alunos trazem para a escola culturas, valores, conhecimentos e atitudes adquiridos nesses contatos" (PORTO, 2001: 33).

Embora a escola chamada tradicional esteja centrada numa estratégia discursiva baseada na linguagem "enciclopédica", cristalizada numa dimensão repetitiva e hierárquica, o aluno é sujeito ativo do conhecimento, e o aprendizado depende de negociação entre as partes. Como temos discutido ao longo do trabalho, o sentido decorre de interações entre o polo destinador e o polo destinatário, fazendo-se nesse "entre" do jogo dialógico. Quando Paulo Freire requisita trazer para a escola o universo do aluno, considera que o discurso educacional deve dialogar com as experiências individuais e coletivas levadas pelo educando à sala de aula, pois delas também depende a constituição de campos de sentidos, e não apenas do discurso formal escolar. O 
educando chega à escola com vivências anteriores e, ao longo da trajetória acadêmica, vai adquirindo conhecimentos também fora dos espaços institucionalmente escolares, dentre os quais podemos incluir as linguagens e mensagens dos meios de comunicação e das novas tecnologias. A educação, ao considerar a experiência individual do aluno, enquanto sujeito que se faz no mundo, deixaria de ser apenas educare, como lembrou Mírian Grinspun, e passaria a ser também educere.

\section{Nova circulação do conhecimento}

A condição comunicativa contemporânea frente ao modelo escolar tradicional resulta num grande desafio para a escola. Isso porque os meios de comunicação, marcados pelas linguagens complexas, estão gerando novas formas de produção, circulação e recepção do conhecimento, fazendo com que os jovens vivenciem experiências de linguagens que vão muito além da tradição verbal: "Essa evidência transforma a sala de aula em espaço cruzado por mensagens, signos e códigos que não se ajustam ou se limitam à tradição conteudística e enciclopédica que rege a educação formal" (CITELLI, 2006: 161). Maria da Graça Setton lembra que a escrita convive com outras linguagens passíveis de transmitir e produzir conhecimentos. "Ainda que o código escrito seja o grande difusor e matéria-prima de toda e qualquer manipulação do conhecimento característico das formações modernas, é preciso observar o surgimento de outros estímulos criativos em nosso meio cultural" (SETTON, 2004: 68). O consumo informativo e cultural se transforma à medida que se concretiza a transição do receptor ao receptor-emissor, apontada por Orozco, o que repercute nas formas de circulação do conhecimento e, consequentemente, na construção da aprendizagem. Delia Crovi também destaca a mudança de processos gerada pela convergência tecnológica, que não apenas permite um recurso expressivo e relacional novo, como a internet, mas também transforma os processos produtivos dos meios já existentes (como exemplos, a digitalização do cinema, a transmissão via satélite do rádio, a produção da TV etc). Segundo a autora, a digitalização permitiu o surgimento de novos meios, de novas formas de produzir, armazenar e difundir a informação e tem modificado substancialmente as relações interpessoais e os sistemas de produção, educação e entretenimento. "Entre los cambios más importantes de orden general, figura una nueva interpretación de la dimensión espacio-temporal de los individuos que pone en juego tanto los conceptos tradicionales, como la organización de su vida cotidiana" (CROVI, 2006: 19). E as mudanças ocorridas no cotidiano acarretam transformações na cultura. 
"La paulatina incorporación de los procesos de convergencia en las diferentes actividades de la vida cotidiana provoca transformaciones en las prácticas culturales" (CROVI, 2006: 47).

Diante desse novo cenário, a aprendizagem transcende o ensino formal, ocorre a qualquer hora e em qualquer lugar. Martín-Barbero destaca que, nesta era de convergência, onde não se lê, não se escreve, não se vê e não se escuta como antes, também não se conhece nem se aprende como antes. Segundo o autor, a mediação tecnológica transforma cada dia mais nossa relação com o mundo: “... la propria presión tecnológica está suscitando la necesidad de encontrar y desarollar otras racionalidades, otros ritmos de vida y de relaciones tanto con los objetos como con las otras personas" (MARTÍN-BARBERO,2008:10). As transformações tecnológicas afetam especialmente a produção e a circulação do conhecimento, o que representa uma grande mudança para a sociedade. O saber encontra-se disperso e fragmentado, escapando ao controle e à reprodução dos lugares legitimados de circulação, como a escola e o livro. A aprendizagem ganha novas direções, rompendo a linearidade dos livros e a hierarquização dos conteúdos escolares, para seguir um novo modelo de organização, baseado na hipertextualidade, em que o sujeito busca o próprio conteúdo, em qualquer direção.
"Son cambios que no vienen a reemplazar al libro sino a relevarlo de su centralidad ordenadora de las etapas y los modos de saber que la estructura-libro había impuesto no sólo a la escritura y la lectura sino al modelo entero del aprendizaje: linearidad secuencial de izquierda a derecha, tanto física como mental, y verticalidad del arriba hacia abajo, tanto espacial como simbólica." (MARTÍN-BARBERO, 2002: 3)

Guillermo Orozco Gómez lembra que grande parte do que aprendemos hoje é resultado de encontros e intercâmbios que não estão na escola, em especial das telas (TV, computador, celular etc) com as quais interagimos diariamente e com as quais convivemos cada vez mais. Além disso, o autor ressalta que os novos fluxos comunicacionais geram estímulos ao desenvolvimento:

“... junto com todo o lixo, violência, antivalores e saturação informativa que os MCM [Meios de Comunicação de Massa] nos trazem, chega-nos também um conjunto de mensagens e programas que constituem um estímulo para a imaginação, a aprendizagem, a vida. Os MCM oferecem múltiplos contatos que antes não eram possíveis. Oferecem uma 'janela para o mundo' e interessantes possibilidades de desenvolvimento pessoal e social, de distração e espairecimento, assim como de aprendizagem constante" (OROZCO, 1997: $61)$. 
Orozco destaca ainda a efetividade de aprendizagem dos meios de comunicação. "Há já suficiente pesquisa a partir da qual se pode afirmar que as crianças aprendem mais e mais rapidamente dos diversos meios de comunicação, e em especial da TV, que do professor na escola" (OROZCO, 1997: 60). E os meios de comunicação promovem a textura da experiência, que acarreta a aprendizagem "antecipatória", levando a uma aceleração cognitiva. "Enquanto na escola queremos produzir uma situação propícia para o ensino-aprendizagem, os meios de comunicação estão reproduzindo situações reais, que se não têm muito que ver com o ensino, têm a ver e muito mais com a facilitação da aprendizagem" (OROZCO, 1997: 60).

Segundo Crovi, as alterações provocadas pelo novo modo de vida, mediado pela tecnologia, podem propiciar um novo tipo de pensamento, menos linear, com maior capacidade adaptativa, o que pede o desenvolvimento de novas competências: "Por su importancia cresciente, las redes plantean, además, la necesidad de contar con habilidades adicionales para manejar sus mecanismos" (CROVI, 2006: 43). MartínBarbero esclarece que a aprendizagem também escapa às demarcações de idade devido ao entorno técnico-comunicativo, levando à destemporalização do saber. Segundo o autor, o espaço-tempo da escola não desapareceu, porém suas condições de existência estão passando por transformações profundas devido não só aos saberes fragmentados com os quais a escola tem que conviver, como também ao fato de que os próprios saberes ensinados na escola encontram-se atravessados por saberes do entorno técnicocomunicativo "regidos por otras modalidades y ritmos de aprendizaje que los distancian del modelo de comunicación escolar" (MARTÍN-BARBERO, 2008: 12). A escola deixou de ser a única agência de promoção educacional, como lembra Adilson Citelli, ao mesmo tempo em que os meios de comunicação tornaram-se mediadores dos processos educativos. "Os polos de formação descentraram-se e tenderão a intensificar cada vez mais as possibilidades de se obter informações e mesmo conhecimentos por meio de mecanismos até há pouco privativos do espaço escolar" (CITELLI, 2000: 22).

Da mesma forma que não se aprende como antes, também não se comunica como antes. Orozco destaca a conectividade e a multitarefa como novas formas de interação comunicativa, de onde se criam novos significantes e se produzem novos significados. "Estar em red es una manera de estar pero sobre todo implica e conlleva una manera de ser, distinguible de otras, con un potencial diferente a otros modos de estar y de ser a la vez" (OROZCO, 2009: 13). O autor lembra, no entanto, que não se nasce audiência; ela se forma a partir da atividade e da interação com as telas, o que pressupõe processos, 
aquisições de habilidades, desenvolvimento de competências e criatividade. Mais uma vez, a educação formal entra em destaque: ela deveria reorientar a aprendizagem obtida fora da escola, ajudando a compreender as diferentes lógicas de produção dos meios audiovisuais e a articular as diferentes linguagens. Porém Orozco ressalta que a escola não dá legitimidade a muitas formas de aprender que são diferentes dos livros, como é o caso das tecnologias e dos meios de comunicação. Para Martín-Barbero, a reação mais frequente da escola frente às novas formas de circulação do conhecimento é de entrincheiramento em seu próprio discurso, "pues cualquier outro modo de saber es resentido por el sistema escolar como un atentado directo a su autoridad" (MARTÍNBARBERO, 2008: 11).

$\mathrm{Na}$ escola, o encontro do campo aparentemente sedimentado da educação com o volúvel terreno das tecnologias da informação ainda é um grande desafio. Segundo José Joaquín Brunner, os governos medem seu grau de sintonia com as mudanças tecnológicas a partir do número de computadores conectados, os professores têm que se adaptar a novas exigências, especialistas divergem sobre as maneiras de se implantar a tecnologia na escola e as empresas ligadas ao mercado educacional dinamizam e ampliam suas atividades e, claro, seu lucro. Diante desse cenário de incertezas, a tecnologia aparece como um elemento alheio à educação, "um fator externo que deve ser 'trazido' para a escola e que, nessas circunstâncias, é pensado de modo puramente instrumental, como uma caixa de ferramentas que se toma emprestada para pô-la a serviço de uma missão humana transcedental" (BRUNNER, 2004: 19).

A tecnologia é vista como instrumento, e não como mediadora da sociedade, o que a reduz ao mundo mecânico e, portanto, exclui a necessidade de reflexão. MartínBarbero lembra, contudo, que a técnica não é neutra; é preciso refletir sobre a transformação causada por ela no ser humano, que passou a ser produtor, criador, dando à técnica uma dimensão de poder. Brunner enfatiza que o ponto realmente importante são as inovações, e não propriamente as tecnologias: "aquelas representam a transformação nas maneiras de ensinar e aprender, enquanto estas proporcionam somente os meios e o novo contexto para esse processo" (BRUNNER, 2004: 74). Para Ismar de Oliveira Soares, as novas tecnologias não são as salvadoras da educação; a questão central da educação deve estar no crescimento do indivíduo enquanto ser humano. "Parece-nos primordial não mais questionar qual o problema da educação e sim quais os problemas do indivíduo que a educação pode ajudar a solucionar" (SOARES, 1999: 36). Segundo o autor, seja na educação formal, não-formal ou 
informal, a aprendizagem ocorre quando o indivíduo sente-se tocado, envolvido, conectado. "Desta maneira, o ambiente mediado por tecnologias pode ajudar a produzir sentidos, convertendo-se em mediação" (SOARES, 2002: 20). Portanto, não é a tecnologia que provoca a aprendizagem, mas sim o sentido, construído, como temos visto ao longo de nosso trabalho, a partir de interações entre os sujeitos envolvidos atravessados por elementos mediadores.

No entanto, a concepção instrumental da tecnologia faz com que seja malinterpretada e mal-utilizada na sociedade. Orozco entende que essa visão é resultado de um dos reducionismos do sistema educativo em relação ao âmbito comunicativo: os ministérios da Educação latinoamericanos encaram as tecnologias de informação e comunicação como meros suportes, os quais carregam os conteúdos tradicionais, só que agora empacotados em materiais audiovisuais. Mantêm-se, segundo Orozco, as mesmas deficiências epistemológicas e conceituais sobre o educativo e o audiovisual.

"En esta perspectiva instrumentalista, a todas luces modernizante, los medios y tecnologías de información son proclamados en lo que tienen de extensionismo y de solución funcional, tecnocrática del problema de la creciente y siempre insatisfecha demanda de las sociedades por educación, ya que permiten 'cacarear' proyectos de 'educación a distancia' y prometer poner televisores y computadoras en donde no se puede enviar a un maestro de carne y hueso o construir una escuela." (OROZCO, 2001: 74)

Orozco destaca que a apropriação instrumental dos meios e das tecnologias cria a ilusão de que o problema da educação será solucionado com programas de educação a distância, funcionando como uma saída política controladora, pois não oferece aos estudantes a compreensão das lógicas de produção do audiovisual ao mesmo tempo em que os mantém dispersos e fragmentados, dificilmente capazes de se organizar coletivamente. Além disso, Crovi ressalta que a educação a distância implica um maior esforço tanto do estudante quanto do docente, pois o primeiro tem que desenvolver a autoaprendizagem, e o segundo precisa preparar uma pedagogia que facilite o processo, o que exige capacitação. Mais uma vez, a questão envolve o recorte dado ao problema da brecha digital - as ações se concentram na infraestrutura técnica, desconsiderando outros aspectos vitais para o completo acesso às redes, as quais poderiam funcionar como canais de participação cidadã: "hay que prestar atención a los capitales cultural e informático de los usuários, con miras a elevarlos, asi como trabajar en la posibilidad de transformarlos en sujetos activos, capaces de participar socialmente via red" (CROVI, 2006: 74). 
Mesmo com a diversidade de linguagens em circulação, há um profundo desencontro entre o discurso didático-pedagógico e as linguagens institucionalmente não-escolares. "Por tal categoria entenda-se a existência de uma pluralidade de signos e códigos que podem abranger desde anúncios publicitários, canções de sucesso, programas televisivos, até videogames e navegação pela Internet" (CITELLI, 2000: 22). O discurso pedagógico é praticamente o único constituinte da retórica escolar, enquanto que as outras linguagens pressionam do lado de fora: “... existem na fala dos alunos e nas conversas dos professores, circulam entre as salas de aula, nos espaços de reunião, nos corredores, no pátio, têm existência subterrânea" (CITELLI, 2000: 22).

A proposta é que a escola, em vez de ignorar ou rechaçar essas novas formas de circulação de conhecimento, reflita sobre elas e use-as para se aproximar do aluno. Maria da Graça Setton esclarece que a aproximação com o discurso que envolve o jovem é uma forma de melhorar a relação entre educandos e educadores. A autora destaca que a escola precisa absorver a linguagem do cotidiano de uma geração que desde cedo socializou-se com a cultura midiática.

"Nesse sentido, não se trata de tornarmo-nos acríticos em relação aos produtos da mídia, mas sim de desenvolver, entre outras estratégias, um espaço de sociabilidade pedagógica via meios de comunicação de massa. Isso seria possível, a meu ver, trazendo a mídia para dentro dos muros escolares, para dentro das salas de aulas." (SETTON, 2004: 67)

Setton considera relevante o uso da produção midiática em sala de aula porque ela faz parte do cotidiano do jovem em processo de escolarização. Embora toda a sociedade esteja submetida a essa nova configuração, baseada no audiovisual, "as gerações mais jovens são as que estão sendo precocemente socializadas pela cultura da imagem, do texto fragmentado, da montagem e bricolagem incessante de informações" (SETTON, 2004: 68). Os processos educativos informais estão presentes no dia a dia do educando, muitas vezes em ruptura com a educação formal. No entanto, se trazida para a sala de aula, a produção midiática pode possibilitar que o estudante reflita sobre sua própria formação. "Ela [a produção midiática] oferece recursos para estes jovens refletirem sobre suas condições de vida, sobre o processo de construção da realidade, bem como pode estimulá-los na manipulação e na reelaboração do conhecimento formal e informal sobre o mundo" (SETTON, 2004: 68). Nessa mesma linha de pensamento, Marília Franco explica que a criança, hoje, exercita suas potencialidades e aptidões não apenas por meio de vivências e brincadeiras, mas também pela proximidade com os meios de comunicação. 
"O consumo das mídias audiovisuais aciona mecanismos profundos de projeção/identificação, desencadeando processos de vivência afetiva tão intensos e modelares quanto os da experiência empírica. Quando a criança chega às mãos do educador já tem plantada, dentro de si, a semente da contradição entre o que lhe fazem desejar e o que lhe é possível realizar." (FRANCO, 2004: 33)

A pesquisadora defende o uso pedagógico das mídias audiovisuais, mas sem cair na armadilha do determinismo tecnológico, como se dotar as salas de aula com aparelhos de TV e computadores fosse a solução para o desinteresse dos estudantes. O importante é trabalhar com as linguagens audiovisuais para estabelecer campos de constituição de sentido entre professor e aluno e, assim, promover a construção do conhecimento. Só que, para isso, o trabalho com os meios de comunicação precisa fazer parte da educação formal. "Esses meios devem estar integrados ao currículo escolar e aos métodos de ensino. O espaço dos recursos audiovisuais deve estar previsto e planejado nos dois" (FRANCO, 2004: 28).

Esse planejamento é essencial para desenvolver na escola as competências para a comunicação, para trabalhar outras linguagens. Não se trata mais de apenas formar receptores críticos, mas também de oferecer condições para uma produção comunicativa permitida pela tecnologia. "A relação da escola com os meios de comunicação precisa ir além da formação do receptor crítico que configurava uma educação para a mídia, cuja preocupação maior se completa numa relação lúcida do usuário com o meio de comunicação" (PORTO, 2001: 28). Tania Maria Esperon Porto esclarece que é preciso preconizar o espaço escolar como um local de produção de conhecimento e, portanto, de cultura. Mário Kaplún também destaca a necessidade de dar lugar à manifestação pessoal no processo de ensino/aprendizagem, valorizando a individualidade dos educandos: "Em lugar de confiná-los a um mero papel de receptores, é preciso criar condições para que eles mesmos gerem mensagens próprias, pertinentes ao tema que estão aprendendo" (KAPLÚN, 1999: 73). O desafio, agora, é múltiplo, o que exige novas pedagogias e novos objetos para serem trabalhados pedagogicamente. "Por ejemplo, el desarrollo de la capacidad para seleccionar información desde las pantallas, a nivel instrumental, semántico y pragmático, y a la vez eficiente e confiable" (OROZCO, 2009: 8).

Orozco destaca que as possibilidades trazidas pela convergência tecnológica, partindo da educação, abrem um vasto campo de oportunidade para ocorrer a produção cultural de fato, e não somente a recepção ou o consumo informativos. Temos a 
possibilidade de transformar o objeto comunicativo, e não apenas a interpretação, superando a condição de aceitação dos modelos que nos colocam para assumir um papel ativo, rumo à educação libertadora defendida por Paulo Freire, ou seja, educação como diálogo, comunicação, interação entre sujeitos cognoscentes mediatizados pelo objeto cognoscível que buscam conhecer. Dessa forma, o processo de aprendizagem pode levar à ação transformadora por parte do educando: “... só aprende verdadeiramente aquele que se apropria do aprendido, transformando-o em apreendido, com o que pode, por isto mesmo, reinventá-lo; aquele que é capaz de aplicar o aprendido-apreendido a situações existenciais concretas" (FREIRE, 1996: 29). Orozco lembra que, através da educação, podemos nos apropriar das novas tecnologias para usá-las em qualquer direção, e não somente como aprendizado instrumental. A experimentação passa a ser decisiva no processo de aprendizagem, pois, como destaca Crovi, a SIC é baseada no conhecimento resultante da experiência, "un conocimiento compartido por todos, público, construido de manera personal" (CROVI, 2006: 49). No entanto, para que a escola atenda a essas novas exigências, faz-se necessário repensar os processos formais.

\section{Replanejamento do processo educativo e formação de professores}

Com a "destemporalização" dos saberes apontada por Martín-Barbero, a aprendizagem passa a ser vista como uma necessidade permanente.

"La educación continuada o el aprendizaje a lo largo de la vida, que exigen los nuevos modos de relación entre conocimiento y producción social, las nuevas modalidades de trabajo y la reconfiguración de los oficios y profesiones, no significan la desaparición del espacio-tiempo escolar pero las condiciones de existencia de ese tiempo, y su particular situación en la vida, se están viendo transformadas radicalmente" (MARTÍN-BARBERO, 2008: 12).

Essa ideia de aprendizagem ao longo da vida, já citada anteriormente com Maria da Glória Gohn e Paulo Freire, é apontada por José Joaquín Brunner como uma das estratégias adotadas pelos países para adaptar a educação às mudanças de contexto:

"Uma educação contínua ao longo da vida para todos representa não só uma estratégia para ampliar a cobertura e o tempo de formação, mas também uma nova concepção educativa que, necessariamente, deverá levar a uma reorganização da escola e de seus processos formativos." (BRUNNER, 2004: 39)

Na visão de Brunner, trata-se de conceber e colocar em prática um novo modo de produzir educação, pois esta, enquanto aprendizagem contínua, passa a ser a própria 
vida. No entanto, tal abordagem exige um "completo redesenho da institucionalidade educacional centrada na escola", afinal, enquanto o ensino formal foi criado visando a uma formação inicial, com um período predeterminado, e está baseado na hierarquia de conteúdos, a educação contínua requer bases mais diversificadas e flexíveis, organizadas em rede.

"A institucionalidade em rede, por sua vez, representa uma configuração diferente: com estruturas abertas, isto é, com limites mutáveis - não fixos - e múltiplas conexões e vias de comunicação entre as unidades ou nodos; com alta frequência de contato entre elas, com hierarquias não-lineares, mas entrecruzadas; com descentralização, flexibilidade, autonomia dos organismos e/ou programas de base (...).” (BRUNNER, 2004: 43)

Importante destacarmos, porém, que achamos primordial que o replanejamento do processo educativo parta de perspectivas reflexivas, isto é, que o ponto de partida sejam os próprios educandos e seus educadores e que seja formado um ecossistema comunicativo na escola, ou seja, um entorno comunicacional com fluxos em todas as direções, integrando professores, alunos e a própria comunidade, e fazendo da escola uma verdadeira experiência cultural. Afinal, como vimos, mais do que aparatos tecnológicos, os meios de comunicação descentram as formas de transmitir e circular conhecimento e, sobretudo, constituem-se como um âmbito de socialização, revelando sua dimensão estratégica: "Es sólo a partir de la asunción de la tecnicidad mediática como dimensión estratégica de la cultura que la escuela puede insertarse em los procesos de cambio que atraviesa nuestra sociedad" (MARTÍN-BARBERO, 1996: 19).

Adilson Citelli chama a reestruturação educacional de "movimento geral de ressignificação da escola", o qual "deverá incluir, necessariamente, o diálogo com os 'concorrentes' mediáticos e as novas tecnologias - sempre considerando o problema na perspectiva das ampliações culturais" (CITELLI, 2000: 23). Porém, para o replanejamento do processo educativo, é necessário superar a posição da escola como mera retransmissora de saberes a decorar e reproduzir. Um uso pedagógico e crítico dos meios só é possível em uma escola que torne viável o trânsito de um modelo centrado na sequência linear a outro descentrado e plural, capaz de conectar o passado ao presente e valorizar as conexões em rede, e não apenas os pacotes de saberes apresentados linearmente. Essa escola também precisa potencializar o educador, que se torna facilitador da aprendizagem: “... de mero retransmisor de saberes se convierte em formulador de problemas, provocador de interrogantes, coordinador de equipos de trabajo, sistematizador de experiencias, memoria viva de la instituición que hace relevo 
y posibilita el diálogo entre generaciones" (MARTÍN-BARBERO, 1996: 20). Nesse redesenho da escola, os meios de comunicação tornam-se "terminais cognitivos", que incitam a apropriação crítica dos conteúdos e a reflexão sobre as transformações geradas por eles. A televisão, o computador, a internet tornam-se dispositivos de aprendizagem, estimulando debates e interações.

Citelli lembra, no entanto, que o movimento de ressignificação da escola tem obstáculos a enfrentar, os quais podem ser articulados em dois grandes planos: o conceitual e o operacional. O plano conceitual diz respeito à dificuldade que os educadores têm de lidar com as linguagens institucionalmente não escolares e da própria carência estrutural da escola, que muitas vezes não detém o aparato tecnológico. Há um certo desconforto dos professores em relação aos meios de comunicação, o que gera insegurança e acaba por afastar os agentes educadores do campo das comunicações. Citelli usa a televisão como exemplo dessa situação: “Ao que parece, não há um domínio conceitual da televisão que corresponda plenamente ao peso que ela possui como fenômeno social. Assim, o trabalho com a televisão em sala de aula tende, no máximo, a tratá-la como meio técnico que cumpre determinadas funções simbólicas e ideológicas" (CITELLI, 2000: 24). Dessa forma, a imagem é usada como mera ilustração do texto oral ou escrito: a escola não apreende o veículo como instância de mediação cultural dotada de linguagem própria. As outras linguagens são usadas na escola como complemento à escrita, e não como fontes de ensino por si sós, resultado do modelo linear e unitarefa adotado pela educação formal. Porto lembra que os meios de comunicação estão na escola como parte da cultura dos alunos, e não apenas como recursos auxiliares, porém as aulas tendem a adotá-los como tais, o que não representa uma real abordagem pedagógica da mídia.

"A abordagem pedagógica precisa, ainda, superar o uso dos meios como recursos auxiliares de um ensino preocupado com a ilustração de suas proposições e que frequentemente se completa com a tomada da 'representação' pela 'realidade', subaproveitando a potencialidade reveladora da representação utilizada e distorcendo a realidade que pretende ser focalizada." (PORTO, 2001: 28)

O uso do mediático e do informático como simples recursos didáticos é mais um reflexo da apropriação instrumental já discutida anteriormente, resultado do reducionismo apontado por Orozco. Outro tipo de reducionismo identificado pelo autor está ligado aos conteúdos e métodos escolares, cujas mudanças mais frequentes estão relacionadas a períodos políticos, e não a avanços pedagógicos. Mesmo quando ocorrem 
algumas evoluções positivas nos métodos, o autor ressalta que as mudanças, na maior parte das vezes, ficam apenas no discurso, pois os docentes e as instituições não assumem de fato as novas propostas ou não têm condições de se adequar a elas. "Es en este nivel de los métodos donde más se aprecia un abismo entre los discursos y las prácticas, entre los diseños en el papel y sus precarias instrumentaciones" (OROZCO, 2001: 74). O autor destaca ainda alguns estereótipos que dificultam a integração entre comunicação e educação: a visão que, em geral, circula entre os educadores, de que a escola é a única instituição legítima para educar, sem levar em consideração que a sociedade vive num cenário cultural plural, repleto de fontes de aprendizagem e educadores espontâneos: “... não se admite que haja outros educadores, que haja a possibilidade de que aqueles que não passaram por algum curso Normal ou por algum curso de Pedagogia, tenham capacidade de facilitar a aprendizagem e, inclusive, ser mais eficientes e efetivos nesse processo" (OROZCO, 1997: 64). Outro desses estereótipos é a ideia de que os meios de comunicação não têm nada de proveitoso à formação dos alunos: “... é pensar que os MCM, e em particular a TV, são uma caixa idiota e que por conseguinte há que se mantê-los o mais longe possível da escola e dos processos educativos" (OROZCO, 1997: 63). Em vez de ensinar a lidar com os meios de comunicação, a escola os repele. Um terceiro estereótipo citado por Orozco está ligado à ideia de que educação "deve ser coisa séria", deve exigir grande esforço dos alunos e não dar espaço para o lúdico nem para a flexibilidade. O lema "educar entretendo" soa como algo inviável. O autor aponta também um estereótipo que diz respeito à recepção. Ainda existe o pensamento de que os receptores são sujeitos passivos, completamente influenciados pelos meios de comunicação. Não se leva em consideração que o receptor é capaz de filtrar as informações que recebe. "A audiência está constituída por um conjunto de sujeitos culturais, historicamente situados, capazes de negociar as mensagens e, eventualmente, de resistir a elas" (OROZCO, 1997: 65).

Jesús Martín-Barbero destaca ainda a insegurança vivida pelo professor, que se sente ameaçado pelo computador, pois teme perder sua função de transmissor do conhecimento. No entanto, o equívoco está na percepção do próprio professor em relação ao seu papel. Martín-Barbero lembra que esse profissional tem a função de intermediador de gerações, e não apenas de transmissor de conhecimento, por isso o computador jamais será uma ameaça ao trabalho docente. O professor é fundamental para que os alunos não sejam meros "tradutores", não apenas saibam repetir a informação, mas realmente consigam refletir, fazer entrecruzamentos, questionamentos 
e assim construir o conhecimento. Paulo Freire resume bem essa função: "O papel de educador não é o de 'encher' o educando de 'conhecimento', de ordem técnica ou não, mas sim o de proporcionar, através da relação dialógica educador-educando, educandoeducador, a organização de um pensamento correto em ambos" (FREIRE, 1996: 53).

Essa questão esbarra, no entanto, em mais um dos reducionismos do sistema educativo em relação ao âmbito comunicativo apontados por Orozco: a exclusão do cultural e do mediático e comunicacional na política educativa da América Latina, desconsiderando o que se passa do lado de fora dos muros escolares. "Más que provisiones sobre estrategias para 'empoderar' a los educandos y a los educadores, lo que se privilegia en estas políticas educativas son prescripciones y normatividades del funcionamiento de los sistemas escolares" (OROZCO, 2001: 72). As políticas educativas deveriam prever o acompanhamento das possibilidades tecnológicas, de forma a verificar o que os jovens estão aprendendo com as tecnologias e assim ajudá-los a desenvolver seu potencial de emissor, para que eles realmente alcancem esse status e tenham o poder de transformação. Da mesma forma, as políticas precisam capacitar os docentes, ajudando-os a fazer a chamada imigração digital, ou seja, desenvolver suas competências para interagir com as novas telas, já que não pertencem à geração que nasceu cercada pelas novas tecnologias. Adilson Citelli ressalta que os professores, muitas vezes, desconhecem novas linguagens ou não se sentem preparados para acionálas como recursos de ensino, consequência da própria estrutura dos cursos de qualificação docente.

\footnotetext{
"Os esquemas que regem as aulas de prática do ensino e didática, assim como as concepções que acompanham os cursos de graduação, por demais circunscritos a balizas acadêmicas nem sempre sintonizadas dialogicamente com as dinâmicas transformadoras da sociedade, têm contribuído muito para que o jovem professor ingresse na carreira no contrapé das experiências com os meios de comunicação e com as novas tecnologias já desenvolvidas pelos alunos." (CITELLI, 2000: 30)
}

Assim como destacou Orozco, Adilson Citelli acredita que a solução depende de políticas educativas, as quais devem abranger as necessidades da formação docente, com mudanças tanto nas licenciaturas e graduações como na formação continuada do educador. $\mathrm{O}$ autor enfatiza também que é preciso reconhecer que "o crescente papel das novas tecnologias e dos meios de comunicação ocupa importante lugar nesse processo" (CITELLI, 2000: 31). 
A questão da formação docente está ligada ao plano operacional que dificulta o movimento de ressignificação da escola, definido por Citelli. Muitos professores não possuem formação superior e, em alguns casos, sequer cursaram o Ensino Médio. Dados do Censo Escolar da Educação Básica 2007, divulgados pelo MEC (Ministério da Educação) em 28/5/2009, mostram que 602.057 alunos têm aulas com 15.982 professores formados apenas no Ensino Fundamental. Em percentuais, os números representam $1 \%$ dos alunos brasileiros e $0,8 \%$ dos professores, porém, só no Nordeste, estão 52,7\% desses estudantes. O Censo indica ainda que, no total, o Brasil tem 119.323 "professores leigos", ou seja, docentes que só concluíram o Ensino Fundamental ou o Ensino Médio e não têm habilitação para lecionar. O número corresponde a $6,3 \%$ do magistério nacional.

Mesmo entre aqueles que cursaram a universidade, a formação dentro do recorte que estamos trabalhando não tem se revelado animadora. Pesquisa realizada por Adilson Citelli em São Paulo com setenta e nove docentes de até trinta anos de idade ilustra essa situação: ainda que sejam profissionais jovens, cujo curso superior teria sido desenvolvido dentro de um cenário tecnológico, apenas $27 \%$ dos professores disseram ter cursado alguma disciplina voltada para o estudo da comunicação na educação durante a graduação ou licenciatura. A constatação não surpreende o pesquisador:

"Após vários anos realizando pesquisas nesta área e repetindo, praticamente a mesma pergunta, constamos um quadro de pouca ou nenhuma mudança. As licenciaturas seguem em impávida direção de menoscabo por uma questão básica nas dinâmicas das sociedades contemporâneas: a presença dos meios de comunicação e das novas tecnologias da informação" (CITELLI, 2008: 14).

A pesquisa mostra também que $79 \%$ dos docentes nunca participaram de um curso de formação visando ao trabalho com os meios de comunicação em sala de aula, porém, entre esses, $89 \%$ gostariam de receber essa capacitação, o que revela "consciência da necessidade de um conhecimento qualificado acerca dos mecanismos de funcionamento das mídias e das linguagens que por elas circulam" (CITELLI, 2008: 16). Além disso, nossa pesquisa mostrará que, mesmo entre os cursos que oferecem alguma disciplina com abordagem ligada à comunicação, essa formação ainda ocupa uma posição periférica, geralmente como parte do currículo opcional.

Apesar de indispensável, a formação e capacitação para transformar a prática docente não é uma tarefa simples. A constatação é de Jorge H. Gutiérrez Martínez, que, a partir de suas experiências em desenvolvimento de programas de educação tecnológica para a América Latina, detectou que um ou dois cursos não são suficientes. 
"Com efeito, os professores levam de três a quatro anos para desenvolver os conhecimentos necessários para integrar, de maneira proveitosa, as tecnologias às suas tarefas docentes, especialmente quando não têm acesso contínuo à prática" (MARTÍNEZ, 2004: 106). O autor destaca a necessidade de que os professores cheguem à prática pedagógica já munidos desse conhecimento prévio sobre como trabalhar com as tecnologias, o que liga a discussão diretamente à nossa proposta de pesquisa: a formação na universidade. "O currículo de formação de professores deve responder às exigências atuais de utilização nas NTIC [Novas Tecnologias da Informação e Comunicação] na prática pedagógica" (MARTÍNEZ, 2004: 106). O autor ressalta também a importância de cursos voltados especificamente para o tema no quadro de especializações e pós-graduações das universidades. O trabalho com as novas tecnologias, e suas múltiplas linguagens, deve partir de dentro do sistema educacional, envolvendo as escolas e as instituições formadoras de docentes, caso contrário será inviável uma transformação no modelo educacional. Fundamental também é que esta formação seja não apenas técnica, mas principalmente reflexiva.

"Com efeito, espera-se que os profissionais que saiam das instituições formadoras de docentes contem com as atitudes críticas, habilidades e destrezas necessárias para que lhes seja possível valorizar e avaliar a pertinência do uso de tecnologias na sala de aula.” (MARTÍNEZ, 2004: 106)

Philippe Perrenoud faz uma importante observação sobre a formação de professores: "Não é possível formar professores sem fazer escolhas ideológicas. Conforme o modelo de sociedade e de ser humano que defendemos, não atribuiremos as mesmas finalidades à escola e, portanto, não definiremos da mesma maneira o papel dos professores" (PERRENOUD, 2002: 12). Ao longo de todo este trabalho, temos defendido uma educação emancipatória, nos termos de Adorno, uma formação autônoma, nos termos de Bolle, uma educação libertadora, nos termos de Paulo Freire, enfim, uma escola que não apenas transmita conhecimento, mas que dê condições ao sujeito de articular o que aprende dentro e fora da instituição formal, partindo de bases reflexivas e em conexão com a condição comunicativa contemporânea. E a formação dos professores segue também essa linha de pensamento: a partir da escola que queremos, é que podemos definir os princípios básicos da formação dos professores. "Esses princípios passam pelo reconhecimento da autonomia e da responsabilidade profissionais dos professores, tanto individual quanto coletivamente" (PERRENOUD, 2002: 15). 
Perrenoud acredita que os problemas enfrentados pelos professores no dia a dia deveriam ser levados em consideração na formação docente, sendo realizada uma análise precisa da realidade da profissão. $O$ autor defende que a formação deve, certamente, antecipar as transformações, porém, para fazer as práticas evoluírem, é preciso descrever as condições e as limitações do trabalho dos professores, buscando formas de contornar as situações, pois essa é a base de toda estratégia de inovação.

"As reformas escolares fracassam, os novos programas não são aplicados, belas ideias como os métodos ativos, o construtivismo, a avaliação formativa ou a pedagogia diferenciada são pregadas, porém nunca praticadas. Por quê? Precisamente porque, na área da educação, não se mede o suficiente o desvio astronômico entre o que é prescrito e o que é viável nas condições efetivas do trabalho docente." (PERRENOUD, 2002: 17)

O pesquisador propõe criar um observatório das práticas e das profissões do ensino, para oferecer uma imagem realista dos problemas, abordando questões como absenteísmo, violência dos alunos, falta de educação, rejeição ao trabalho e outros dilemas que os professores enfrentam na sala de aula. Para Perrenoud, o fato de os cursos de formação inicial não abordarem a amplitude desses problemas provoca inúmeras desilusões, já que existe uma defasagem entre a formação e a realidade da profissão.

"Os alunos que querem tornar-se professores conservam a ilusão de que se deve apenas dominar os saberes para transmiti-los a crianças ávidas por se instruir. A resistência, a ambivalência, as estratégias de fuga e a astúcia dos alunos desconcertam os professores novatos, assim como o enfrentamento permanente com algumas classes ou a desorganização crônica de alguns estabelecimentos escolares." (PERRENOUD, 2002: 18)

As questões que envolvem o dia a dia dos professores, no entanto, ficam à margem dos cursos, especialmente pelo fato de que os próprios formadores dos futuros professores não são os profissionais que estão na sala de aula atual. Ou são especialistas que "imaginam que sabem o que acontece em sala de aula" porque lecionam na universidade ou porque conhecem a teoria, ou são antigos professores do Ensino Fundamental e Médio, que pensam conhecer a profissão a partir de seu interior porque um dia deram aula. Segundo Perrenoud, os professores que estão na ativa e convivem diariamente com os desafios da sala de aula não participam do planejamento dos programas de formação. Antonio Nóvoa compartilha essa visão e critica o que chamou de "consenso discursivo" sobre o papel dos professores. De acordo com o autor português, existe um consenso sobre a importância do professor reflexivo e da aprendizagem ao longo da vida, requisitos difundidos por especialistas e pesquisadores 
ligados à área de Educação. As pesquisas e os escritos desses grupos, nos quais o próprio Nóvoa se insere, contribuíram para renovar os estudos sobre a formação docente. No entanto, os professores não participaram dessa "inflação discursiva" sobre eles próprios.

"A inflação retórica sobre a missão dos professores implica dar-lhes uma maior visibilidade social, o que reforça o seu prestígio, mas provoca também controles estatais e científicos mais apertados, conduzindo assim a uma desvalorização das suas competências próprias e da sua autonomia profissional. Se não atendermos a este paradoxo dificilmente compreenderemos algumas das contradições que atravessam a história da profissão docente." (NÓVOA, 2009: 15)

Os professores não foram os autores dos textos sobre a profissão, não foram os protagonistas de uma intervenção em seu próprio campo, tendo apenas um papel secundário na formação docente e na investigação educacional. O resultado, segundo Nóvoa, é um excesso de discursos que frequentemente esconde uma pobreza das práticas. "Temos um discurso coerente, em muitos aspectos consensual, mas raramente temos conseguido fazer aquilo que dizemos que é preciso fazer" (NÓVOA, 2009: 17). $\mathrm{E}$, para isso, é preciso que os professores tenham um lugar predominante na formação de seus colegas. Assim como Perrenoud, Nóvoa propõe reforçar as práticas de formação docente baseadas numa investigação da ação dos professores na sala de aula e do trabalho escolar. E vale destacar o esclarecimento do autor a respeito da questão da prática:

"Não se trata, escusado será dizer, de defender perspectivas de mitificação da prática ou modalidades de anti-intelectualismo na formação de professores. Tratase, sim, de afirmar que as nossas propostas teóricas só fazem sentido se forem construídas dentro da profissão, se forem apropriadas dentro de uma reflexão dos professores sobre o seu próprio trabalho. Enquanto forem apenas injunções do exterior, serão bem pobres as mudanças que terão lugar no interior do campo profissional docente." (NÓVOA, 2009: 19)

As palavras de Nóvoa nos fizeram refletir sobre a nossa própria posição enquanto pesquisadores de um campo de intersecção entre comunicação e educação. Partimos da perspectiva comunicacional, porém é inevitável que adentremos o campo da educação, contribuindo para inflar ainda mais o discurso sobre o papel dos professores, agora imbuídos também da missão de trabalhar outras linguagens na escola. Se, num primeiro momento, essa reflexão nos causa desconforto, por pertencermos ao grupo que fala porém não vive a realidade da sala de aula, num segundo momento percebemos que nossa pesquisa não se trata apenas de mais uma forma de inflar o discurso, pois fomos a campo investigar a formação dos futuros professores. Mais do que discussões e 
reflexões sobre o tema, adentramos o universo dessas pessoas, identificando seus interesses, seus conflitos, sua visão sobre a educação e sobre a comunicação. Entrevistamos jovens que já sentem o paradoxo da profissão que escolheram, pois todos fazem estágio e muitos atuam como professores eventuais. Acreditamos que a pesquisa empírica com os futuros docentes nos permitiu chegar mais próximo do cerne da questão, afinal, além de defendermos que a comunicação seja trabalhada de forma ampla na sala de aula, também fomos verificar como a questão é abordada junto aos profissionais que em breve estarão no centro do processo e qual seu posicionamento sobre a inter-relação comunicação/educação. A alimentação retórica é evidente, porém acreditamos que estamos contribuindo também para a questão prática, dentro da perspectiva adotada por Perrenoud e Nóvoa, já que abrimos o discurso para os futuros professores. As considerações a respeito da pesquisa empírica serão apresentadas à frente, principalmente nos Capítulos V e VI, sobre descrição e interpretação dos dados, mas achamos importante fazer esta reflexão como parte do exercício da vigilância epistemológica de que fala Lopes, elucidando todo o percurso trilhado pelo pesquisador.

\section{Escola como centro articulador da aprendizagem}

A partir do replanejamento do processo educativo, a escola poderia promover uma rearticulação pedagógica entre os meios e as audiências. Orozco propõe que, além de vermos, ouvirmos e desfrutarmos os meios, falemos com eles e os usemos inteligentemente em prol do sujeito-audiência, por meio de comentários, análises, enfim, de uma desconstrução pedagógica. Porém, para isso, é preciso mudar a visão de que os meios são apenas fonte de entretenimento e informação. No caso da televisão, Orozco ressalta que a TV comercial e mesmo a que se diz educativa certamente têm metas mercadológicas, o que não significa que devemos rechaçar seus conteúdos, pelo contrário, devemos trabalhar para que as audiências aprendam conscientemente a partir de seu programa preferido. "No se trata de hacer nuevas producciones televisivas, sino de hacer llegar a las audiencias las estrategias y los recursos para aprender conscientemente de la programación comercial de su preferencia" (OROZCO, 2001: 103). O contexto de aprendizagem propício para uma intervenção pedagógica deve ter como referente a programação que o estudante aprecia, e não uma programação especial ou instrutiva. Segundo o pesquisador, qualquer programa pode se tornar educativo. $O$ docente não precisa preparar um material específico, pois ele já está pronto: embora tenha sido feito para outros fins, pode ser readaptado ao contexto educativo. Por 
exemplo, cenas e temas de uma telenovela podem ser reconvertidos em material didático. Segundo Orozco, os programas da TV comercial ou os conteúdos veiculados na internet podem funcionar como estratégias para extrair e sistematizar o aprendizado obtido pelo estudante das mais diversas fontes.

Marilia Franco também afirma que "qualquer produto audiovisual é passível de uso nas atividades pedagógicas" (FRANCO, 2004: 34). A autora esclarece que o dia a dia dos alunos está impregnado pelo consumo da comunicação audiovisual e que a escola não precisa criá-la artificialmente dentro do contexto escolar por meio de materiais educativos. O importante é buscar compreender a natureza dos processos de desenvolvimento da linguagem audiovisual, e isso se mostra possível quando o professor, que é também um consumidor audiovisual, torna-se um espectador especializado, alguém com condições de desmitificar o mundo das mídias.

"Os hábitos de análise da comunicação audiovisual, que incluam a exploração dos seus elementos estéticos e expressivos, como portadores de seus 'vícios e virtudes' narrativas, certamente, facilitará muito a construção de uma fruição consciente desses produtos culturais, de qualquer nacionalidade. Esclarecerão acerca dos mecanismos de apreensão sensorial, afetiva e intelectual das linguagens audiovisuais, abrindo a possibilidade de que seu consumo seja um agente positivo na formação da personalidade." (FRANCO, 2004: 34)

Os programas comerciais podem ser trabalhados em sala de aula, pois, como lembra Setton, a mídia compõe a "narrativa da contemporaneidade", representa um discurso sobre a realidade do social. Segundo a autora, é possível utilizar "qualquer produto da cultura das mídias, independente de sua especificidade, como elemento problematizador da nossa cultura, desde que submetido a uma análise crítica e compreensiva" (SETTON, 2004: 15). Orozco ressalta que devemos utilizar critérios não para levar o jovem a desligar a TV, mas sim para torná-lo mais seletivo, sabendo explorar e analisar o programa a que está assistindo. Para o autor, a desconstrução pedagógica deveria promover um novo olhar:

"Debería proporcionar una alfabetización al lenguaje de la imagen, que les permita 'ver' sus manipulaciones y estereotipos, 'escuchar' sus silencios, 'notar' sus exclusiones y, en última instancia, 'toma distancia' de la programación. Devería educar su percepción de las formas y formatos televisivos, de sus flujos y sus intentos de seducción." (OROZCO, 2001: 101)

Na sociedade da informação e do conhecimento, a educação precisa "capitalizar" pedagogicamente essa acumulação de imagens, informações, formas, formatos e conteúdos oferecidos aos jovens. E isso pressupõe, segundo Orozco, mais do que 
construir ofertas programáticas educacionais, as quais certamente são legítimas e bemvindas, mas é essencial tornar evidente para as audiências o que está em jogo na programação comercial e criar espaços de aprendizagem propícios para isso. A escola não pode perder a chance de reorientar o que o educando aprendeu do lado de fora e, para isso, precisa assumi-lo como sujeito-audiência, bem como incorporar os meios e seus conteúdos às propostas pedagógicas, desenvolvendo estratégias para "reconvertirse en centro articulador de los aprendizajes que sus alumnos tengan desde otras fuentes e instituciones" (OROZCO, 2001: 106). O processo de evidenciar o que não está aparente à primeira vista nos meios deve partir dos sujeitos e de seus contextos particulares e implica uma participação investigativa, e não receptiva, dos sujeitos, visando a transformá-los, como vimos anteriormente, em usuários. Orozco lembra que são as perguntas sobre as mensagens transmitidas e sua permanente problematização o que constitui o motor do processo de evidenciar, nunca as respostas. "Estas son siempre sus productos, no sus insumos. La curiosidad es la destreza básica que debe fortalecerse en este proceso y el desafío su soporte" (OROZCO, 2001: 108). Dessa forma, como propôs a reflexão inicial do autor, a escola poderia aproveitar o que os meios oferecem, aquilo que já existe, de maneira crítica e independente, contribuindo para o desenvolvimento do sujeito-audiência. A intenção é a educação das crianças e jovens para conectar-se de outras maneiras com os meios, aproveitando-os para seus próprios objetivos. É um desafio, como diz Orozco, de "empoderamento", não de mera alfabetização digital, visando ao desenvolvimento de competências para uma cidadania comunicativa, já que a cidadania, em tempos de sociedade da informação e do conhecimento, não pode ser entendida fora de nossa interação com os meios. Nesse sentido, Porto lembra que o conhecimento das linguagens das mídias oferece condições aos alunos de viverem como sujeitos e participarem num mundo de relações.

"Linguagens que ultrapassam a relação deles com os meios de comunicação, porque possibilitam comunicações entre professores e alunos, entre alunos e de ambos com o saber popular e/ou científico veiculado pelas diferentes mídias, desde as tradicionalmente aceitas pela escola (livros, periódicos), até as mais atuais e muitas vezes não exploradas no âmbito escolar (vídeos, revista em quadrinhos, televisão etc.)." (PORTO, 2001: 28)

A autora explica que trazer os meios de comunicação para a escola não significa "falar sobre" os meios, mas sim "dialogar com" eles e suas linguagens. Heloisa Dupas Penteado também esclarece que o objetivo da aproximação dos campos da educação e da comunicação vai além do trabalho com os meios de comunicação, visando a 
desenvolver o processo de educação escolar como um processo comunicacional, o qual está sempre permeado pelos processos comunicacionais midiáticos, mesmo quando não há presença física das mídias tecnológicas, pois elas estão presentes na cultura de seus usuários. A pesquisadora lembra que as novas tecnologias da comunicação são prolongamentos refinados da capacidade comunicacional inerente ao ser humano, podem ser potencializadoras dessa capacidade, mas não basta apenas introduzir os recursos na sala de aula para transformar a educação escolar.

"Portanto, será tão-somente na vivência de uma didática que exercite a capacidade comunicacional humana e pratique a educação como um processo específico de comunicação que as tecnologias comunicacionais ganharão a possibilidade de exercer o seu poder transformador, rumo a uma educação escolar formadora, reveladora, suporte para o exercício pleno da verdadeira cidadania." (PENTEADO, 2001: 14)

Formar a competência comunicativa do educando é o objetivo maior do trabalho com os meios. E, para isso, o Professor Doutor Ismar de Oliveira Soares, coordenador do Núcleo de Comunicação e Educação da Universidade de São Paulo (NCE-USP), defende inclusive a existência um novo campo de intervenção social, a Educomunicação, definida a partir do seguinte conceito:

“... o conjunto das ações inerentes ao planejamento, implementação e avaliação de processos, programas e produtos destinados a criar e a fortalecer ecossistemas comunicativos em espaços educativos presenciais ou virtuais, tais como escolas, centros culturais, emissoras de TV e rádio educativos, centros produtores de materiais educativos analógicos e digitais, centros coordenadores de educação a distância ou 'e-learning', e outros...” (SOARES, 2001: 115)

A Educomunicação problematiza os campos da comunicação e da educação, de forma a criar e fortalecer ecossistemas comunicativos em espaços educativos. Isso significa, segundo Soares, criar e rever as relações de comunicação na escola, entre direção, professores e alunos, bem como da escola para com a comunidade, criando sempre ambientes abertos e democráticos. É preciso abolir as formas autoritárias de comunicação, cuidando "da saúde e do bom fluxo das relações entre as pessoas e os grupos humanos, bem como do acesso de todos ao uso adequado das tecnologias da informação" (SOARES, 2006). O ecossistema comunicativo está sempre em construção e, para que possa ser aperfeiçoado, é fundamental ter cuidado na forma como o tema é introduzido. Por isso, no início faz-se necessário evitar rejeições e conflitos com os educadores e agentes sociais que defendem concepções mais tradicionais de relações humanas nos espaços educativos. O importante, segundo Soares, é encontrar pontos de consenso, como a necessidade de se melhorar as habilidades de professores e alunos no 
manejo das tecnologias da informação. A Educomunicação depende de todos os agentes envolvidos, portanto, ela jamais pode ser imposta; é preciso conquistá-los, fazer alianças, sempre levando em consideração as condições específicas de cada ambiente.

As ações da Educomunicação destinam-se, também, a integrar o estudo sistemático dos sistemas de comunicação às práticas educativas. Soares lembra que a proposta é efetivamente cumprir o que solicitam os Parâmetros Curriculares Nacionais no que diz respeito a observar como os meios de comunicação agem na sociedade e buscar formas de colaborar com os alunos para conviverem com os meios de comunicação de forma positiva. O objetivo é desenvolver o espírito crítico dos usuários dos meios massivos, assim como usar adequadamente os recursos da informação nas práticas educativas. A Educomunicação também se propõe a melhorar o coeficiente expressivo e comunicativo das ações educativas, ou seja, facilitar o processo de aprendizagem e incentivar alunos, professores e comunidade a se expressar. $\mathrm{O}$ chamado novo campo trabalha com temas transversais, valoriza o conhecimento como um todo, e não apenas informações compartimentadas. Segundo Soares, não basta realizar ações isoladas, pois uma ação isolada não é capaz de modificar as relações de comunicação existentes num ambiente marcado por práticas autoritárias. É importante prever e planejar conjuntos de ações, incluídos no plano pedagógico das escolas. Além disso, todo planejamento parte de uma perspectiva participativa, envolvendo as pessoas ligadas à comunidade escolar, sejam elas agentes ou beneficiárias. Essencial também é que as relações de comunicação sejam sempre francas e abertas, afinal, a comunicação é vista como uma forma de socializar e criar consensos, e não como uma maneira de persuasão.

Nessa perspectiva educomunicativa ou de escola como centro articulador de aprendizagens, o professor exerce o papel de mediador, de facilitador da aprendizagem, alguém capaz de ajudar o aluno a articular os conhecimentos adquiridos dentro e fora do espaço escolar. Porém, para isso, a formação docente deve ser comunicação, e não simplesmente extensão, como disse Paulo Freire. A partir do momento que o próprio docente aprofunda sua tomada de consciência da realidade e consegue problematizar suas relações com o mundo e com os outros homens, a sala de aula poderá se tornar uma experiência cognoscente de mão dupla, com professor e aluno exercendo seus papeis de sujeitos fundamentais do processo de constituição de campos de sentido. 


\section{Algumas considerações}

Nossas reflexões nos direcionam a reconhecer a existência, tanto na mídia quanto na escola, de espaços interdiscursivos por onde transitam os signos, ficando a construção dos sentidos dependente de uma série de variáveis, inclusive sociais e culturais. A interdiscursividade aproxima os campos da comunicação e da educação, estabelecendo um jogo dialógico entre instituições comunicacionais e escolares, porém não livre de tensões, e é desejável que assim seja, afinal, a ideia não é que a escola incorpore acriticamente modelos ou conceitos a partir dos meios de comunicação e das novas tecnologias, mas sim use seu espaço e sua capacidade sistematizadora para analisar os processos envolvidos e compreender as significações colocadas em circulação por esses sistemas. Ao trabalhar novas linguagens, a escola não apenas reconhece a existência de novos modos de produzir, circular e receber o conhecimento, como também aciona os outros saberes do educando, colocando-o como sujeito de seu aprendizado em construção, e não apenas "depositório" de informações hierarquizadas e compartimentadas.

Para essa abordagem, é importante superar estereótipos que colocam a mídia como polo emissor com impacto direto no aluno ou que veem os meios de comunicação como agentes de dominação e manipulação, e passar a considerar os elementos mediativos no jogo em que se define o sentido. Nossa pesquisa parte desses pressupostos e coloca o professor como elemento-chave do processo, pois o docente é o facilitador da aprendizagem e, como lembra Orozco, a formação de receptores conscientes e reflexivos está em grande parte nas mãos dos educadores: “... seja o que for que façam ou deixem de fazer - os professores, na escola, têm importância para a recepção que os estudantes fazem dos diversos meios de comunicação" (OROZCO, 1997: 66). No entanto, cabe averiguar se o professor recebe, em sua formação inicial, subsídios para cumprir esse papel e traduzir a inter-relação comunicação/educação em suas práticas de ensino. 


\section{CAPÍTULO III - Hipóteses}

A partir da definição do referencial teórico, podemos elaborar as hipóteses que vão orientar a pesquisa de campo. Segundo Lopes, as hipóteses têm sua origem na problemática teórica, pois as fontes básicas de sua construção são as operações iniciais de elucidação conceitual do problema e sua contextualização num quadro teórico de referência. Elas se constituem, portanto, em hipóteses teóricas da pesquisa, mas são traduzidas em hipóteses de trabalho, ou seja, afirmações condicionais que têm o objetivo de orientar o estudo. As hipóteses podem ser modificadas parcial ou totalmente no decorrer da pesquisa. "Ao término da investigação, espera-se a confirmação, a rejeição (total e parcial) ou a formulação de novas hipóteses" (LOPES, 2005: 140). O sistema de hipóteses tem a função de fornecer a conexão necessária entre teoria e investigação. "Ao surgirem relações entre conceitos e variáveis, as hipóteses se definem como meios pelos quais a teoria intervém na investigação e nos fatos" (LOPES, 2005: 140). Assim, faz-se necessário estabelecer hipóteses centrais, mais amplas, e hipóteses secundárias, mais específicas, de forma a articulá-las e inter-relacioná-las em movimentos de indução e dedução.

\section{Hipóteses centrais:}

- O futuro professor não recebe, ou recebe de forma periférica, uma formação voltada para trabalhar a inter-relação comunicação/educação em sala de aula;

- O graduando que se prepara para a atuação docente tem uma relação de proximidade com os recursos tecnológicos;

- O futuro professor vê a recepção do aluno de maneira homogênea, e não como uma nova produção de sentidos, sem identificar que as novas formas de circulação do conhecimento geradas pelos meios de comunicação e pelas tecnologias interferem na recepção da mensagem.

\section{Hipóteses secundárias:}

- O estudante que se prepara para a profissão docente acredita na importância da integração entre comunicação e educação, mas necessita de orientação sobre como traduzir essa inter-relação em suas práticas de ensino;

- Mesmo que tenha familiaridade com os recursos tecnológicos, o futuro professor tende a fazer uso instrumental da tecnologia na educação formal. 


\section{CAPÍTULO IV - Observação dos dados}

De acordo com o modelo metodológico proposto por Lopes, o processo de observação tem o objetivo de reconstruir empiricamente a realidade. "As operações envolvidas nessa fase (...) visam coletar e reunir evidências concretas capazes de reproduzir os fenômenos em estudo no que eles têm de essencial" (LOPES, 2005: 142). Esse é o momento em que a ruptura epistemológica deve ser realizada na prática, pois a realidade não pode ser apreendida de imediato e sua reprodução exige atividades intelectuais complexas. "O importante não é o que se vê, mas o que se vê com método, pois o investigador pode ver muito e identificar pouco e pode ver apenas o que confirma suas concepções" (LOPES, 2005: 143).

Nesse sentido, Pierre Bourdieu destaca que é essencial o treino constante na vigilância epistemológica, submetendo a utilização das técnicas e dos conceitos a questionamentos sobre as condições e limites de sua validade. Dessa forma, a vigilância "proíbe as facilidades de aplicação automática de procedimentos já experimentados e ensina que toda operação, por mais rotineira ou rotinizada que seja, deve ser repensada, tanto em si mesma quanto em função do caso particular” (BOURDIEU, 1999: 14).

Lopes destaca que a observação abrange duas operações distintas: a amostragem e a coleta dos dados.

\section{Amostragem}

O objetivo das técnicas de amostragem é delimitar o universo de investigação, isto é, o conjunto de unidades (as quais podem ser pessoas ou não) tornadas fontes de informação ou informantes da pesquisa. O uso das técnicas de amostragem é norteado pelo objeto e sua problemática, sendo necessário, nesse momento, o exercício da vigilância epistemológica sobre as técnicas, já que essas se apoiam, segundo Lopes, em pressupostos teóricos sobre o social.

Há duas grandes técnicas de amostragem: a probabilística (baseada na aplicação de métodos de tratamento estatístico e métodos quantitativos de análise) e a nãoprobabilística (em que a inferência estatística não pode ser legítima - a amostra é dita significativa e os métodos de tratamento dos dados são qualitativos).

Utilizamos em nossa pesquisa a técnica não-probabilística de amostragem, pois, embora ela não represente o todo, é significativa e pode contribuir para a percepção da existência de um fenômeno. O corpus é formado pelas grades curriculares dos cursos de licenciatura em Pedagogia e de bacharelado/licenciatura em Letras com habilitação em 
Português ${ }^{5}$, bem como por alunos dos últimos semestres desses cursos de duas universidades da cidade de São Paulo, uma pública e uma privada: USP (Universidade de São Paulo), localizada no bairro do Butantã, zona oeste da cidade, e UNICSUL (Universidade Cruzeiro do Sul), localizada em São Miguel Paulista, zona leste da capital. Também utilizamos dados secundários, provenientes de institutos oficiais, que nos ajudassem a formar um quadro da educação superior e da formação do professor no Brasil, de forma a contribuir com a interpretação dos dados.

A opção por futuros educadores oriundos de uma universidade pública e de uma particular teve a intenção de diversificar o corpus e possibilitar comparações sobre a formação oferecida pelas instituições e os públicos que as frequentam. Em relação à escolha das graduações, optamos por Pedagogia não só porque o curso forma docentes para as primeiras séries do Ensino Fundamental, em que o trabalho com novas linguagens já são bem-vindos, mas também devido à importância fundamental do "educador-gestor", isto é, o orientador educacional, o coordenador pedagógico, o diretor, entres outros, cujas ações têm papel decisivo sobre os processos escolares. Escolhemos ainda o curso de Letras com a intenção de verificar a formação do professor para o Ensino Fundamental e Médio, e optamos por verificar o currículo da Licenciatura e do Bacharelado para alcançar uma visão mais completa, afinal, ainda que o objetivo do bacharelado não seja formar professores, algumas disciplinas poderiam se aproximar da proposta de inter-relacionar comunicação/educação. Consideramos também que a habilitação em Português seria a mais condizente dada sua abrangência, já que o ensino da Língua Portuguesa perpassa todos os anos escolares.

Optamos por futuros professores, isto é, pessoas matriculadas em cursos universitários que preparam para a docência, e não profissionais em serviço, porque gostaríamos de verificar a abordagem do tema comunicação/educação na universidade e a percepção do futuro professor sobre essa inter-relação antes de ingressar efetivamente no mercado de trabalho. Há a intenção de, no futuro, fazer pesquisas com professores experientes e estabelecer comparações com a investigação realizada neste momento.

Nossa amostra conta com um total de 86 pesquisados, sendo 45 estudantes da UNICSUL (22 de Licenciatura plena em Pedagogia e 23 de Licenciatura plena em Letras) e 41 estudantes da USP (19 de Licenciatura plena em Pedagogia e 22 de Letras, sendo 18 de Bacharelado/Licenciatura e 4 somente de Bacharelado). A amostragem

\footnotetext{
${ }^{5}$ Embora, em geral, os alunos frequentem habilitações duplas, optamos por analisar somente o currículo de Português por ser a habilitação obrigatória e mais condizente com nossa pesquisa.
} 
completa integra a primeira etapa da pesquisa de campo, a aplicação de questionário. Posteriormente, a amostra foi reduzida para 22 pessoas, as quais participaram da segunda etapa, a entrevista presencial, que totalizou 16,5 horas de gravação.

\section{Técnicas de coleta de dados}

As técnicas de coleta são os instrumentos por meio dos quais são obtidos os dados da pesquisa. Elas são, de acordo com Lopes, técnicas de observação ou de investigação e constroem empiricamente o objeto por meio dos fatos coletados. As técnicas, ao serem escolhidas, conferem um significado epistemológico ao tratamento do objeto e um significado teórico aos problemas que se apresentam. Vale lembrar que as técnicas não são neutras; elas são selecionadas, combinadas e construídas para atender aos propósitos da pesquisa, por isso, sua utilização deve ser feita de maneira crítica. A esse respeito, Michel Thiollent destaca que "as técnicas de pesquisa não deveriam ser ensinadas como receitas ou instrumentos neutros e intertrocáveis, mas sim como dispositivos de obtenção de informação cujas qualidades, limitações e distorções devem ser metodologicamente controladas" (THIOLLENT, 1980: 22).

A escolha de uma técnica não é aleatória; ela cumpre um propósito e tem suas limitações, por isso a combinação revela-se a maneira mais abrangente de investigação. Segundo Lopes, uma técnica ilumina o que a outra não conseguiu, e assim elas se complementam para a melhor visualização do objeto. Essa etapa de observação pode ser realizada de forma direta (o investigador manipula estrategicamente sua posição para obter os dados, recorrendo ao registro sistemático dos fatos ou a diversas modalidades de observação participante) ou indireta (questionário, formulário, história de vida e entrevista- essas são as principais técnicas de coleta da pesquisa empírica).

No presente estudo, utilizamos técnicas de observação indireta, por meio de questionário e entrevista. A opção por questionário ocorre num primeiro momento para o levantamento de dados sobre formação, hábitos midiáticos, familiaridade com as tecnologias e perfil socioeconômico dos grupos pesquisados. Já as entrevistas foram utilizadas para de fato focar a investigação nos objetivos propostos. Acreditamos que, com a técnica de entrevista, a pesquisa torna-se mais rica e pode gerar novos desdobramentos. Além disso, consideramos importante a combinação de técnicas de coleta, pois, como dissemos anteriormente, uma pode complementar a outra na construção do objeto. 
Nossa preocupação principal nesta etapa foi chegar ao ideal proposto por Lopes no modelo metodológico que estamos seguindo: ver com método. Durante todo o processo de coleta de dados, nos esforçamos para vencer o "olhar viciado", romper com o senso comum e de fato coletar dados que pudessem ser transformados em dados científicos. Certamente nossa opção pelas técnicas de coleta apresentadas foi intencional, de forma a garantir que os resultados fossem alcançados e as hipóteses pudessem ser testadas. Não temos a "ilusão da imaculada percepção", como aponta Michel Thiollent, isto é, o "mito cognitivo segundo o qual seria possível observar ou perceber o real sem conceitos ou categorias preexistentes ao ato de observar ou de perceber" (THIOLLENT, 1980: 20). A observação considerada neutra e desprovida de interferências não passa de uma ilusão, já que, entre o sujeito e o objeto, existe uma série de mediações, como a linguagem, as teorias, os aspectos culturais, sociais, ideológicos etc. Thiollent lembra que é preciso "levar em conta as pré-teorias disponíveis para construir modelos explicativos ou interpretativos a serem testados por diversos procedimentos de pesquisa" (THIOLLENT, 1980: 21).

Consideramos as técnicas de coleta como meios de captação da informação, a serem criticados, e não como fins em si, e procuramos manter o constante controle metodológico proposto por Thiollent. Para isso, durante a análise revelaremos as fontes de distorção, pois, como lembra o autor, o uso das técnicas de coleta está sujeito a distorções, "inclusive a distorção inerente à distância cultural existente entre o universo acadêmico e o mundo das pessoas investigadas e que interfere na obtenção dos dados" (THIOLLENT, 1980: 21). O permanente questionamento e a articulação com a problemática teórica são decisivos para assegurar a veracidade científica da pesquisa.

\section{Relato sobre a coleta de dados nas universidades}

Realizamos a pesquisa de campo nas universidades em duas etapas: aplicação de questionário a estudantes dos últimos semestres dos cursos de Letras e Pedagogia e realização de entrevistas presenciais. A abordagem foi diferenciada entre UNICSUL e USP por questões operacionais. Na UNICSUL, uma universidade privada e com acesso restrito, iniciamos o contato cerca de seis meses antes de ir a campo. Uma das professoras da universidade e que cursa Doutorado na USP muito nos ajudou nesse processo, pois fez a mediação inicial entre a pesquisadora e a pró-reitoria de graduação. Elaboramos uma carta explicando os objetivos da pesquisa e solicitando autorização para adentrar a universidade e conversar com os alunos. A UNICSUL retornou 
solicitando alguns esclarecimentos, então, após nova carta, obtivemos o aceite e pudemos iniciar a coleta de dados, o que ocorreu em setembro de 2009. Imaginávamos que conseguiríamos realizar a pesquisa simultaneamente nas duas universidades, porém, dada a distância da instituição privada em relação ao domicílio da pesquisadora (50 quilômetros) e o tempo reduzido dos alunos, que em geral precisavam partir logo após a aula, percebemos que a pesquisa iria se estender e resolvemos nos concentrar nesse momento somente nessa universidade, de forma a concluir os trabalhos no semestre.

A aplicação do questionário na UNICSUL ocorreu em apenas um dia, pois os professores gentilmente cederam parte da aula para que a pesquisadora se apresentasse e entregasse os questionários, e os alunos puderam responder ali mesmo. Foram 23 questionários respondidos por estudantes do sexto semestre do curso de Letras com habilitação Português/Inglês e 22 do sexto semestre de Pedagogia, ambos matutinos. A partir daí iniciamos o processo mais demorado, as entrevistas presenciais, que levaram quase três meses para sua finalização. $\mathrm{O}$ contato com os alunos era feito inicialmente por e-mail, agendando data e horário para as conversas, realizadas na própria universidade, em salas de aula desocupadas ou na praça de alimentação. O mais difícil nessa etapa foi conciliar datas e horários, pois grande parte dos alunos trabalha, como veremos adiante, e precisava sair rapidamente após o término das aulas. Por isso, voltamos à universidade diversas vezes para realizar as entrevistas, as quais em geral ocorreram no início ou no final da manhã, ou seja, antes ou depois das aulas.

Mesmo com o tempo reduzido, os estudantes da UNICSUL mostraram-se bastante solícitos. No início, houve certa desconfiança e resistência, o que é natural, afinal, a pesquisadora é uma pessoa externa àquele ambiente. Porém, aos poucos, com nossa presença constante nos corredores, o contato foi se tornando mais natural, menos formal, e pudemos contar com a participação dos alunos, entrevistando inclusive uma pessoa a mais que o nosso objetivo inicial, que era de cinco pessoas por curso em cada universidade. Na UNICSUL, entrevistamos cinco estudantes de Pedagogia e seis de Letras. Durante as conversas, percebemos também que o fato de a pesquisadora vir de uma universidade pública intimidou os alunos. Um dos estudantes admitiu que teve receio de participar ao saber que a pesquisa era para a USP, outro disse que a instituição pública "não é para eles, que moram na periferia", outro fez questão de destacar que seu curso "é muito bom, embora não seja de uma universidade pública". Enfim, relatos que nos fizeram perceber como a universidade pública carrega o estigma de algo intangível. Falaremos melhor sobre isso na interpretação dos dados, porém o que queremos 
destacar agora é que essa intimidação pode ser fonte de distorções, pois, como já apontou Thiollent, a distância entre pesquisador e pesquisado também interfere nos resultados da pesquisa. Esse fato pode ser notado principalmente na tabulação dos questionários, como veremos a seguir, porém procuramos elaborar as perguntas de forma a conseguir identificar distorções, expondo-as durante a análise descritiva, e complementar com a técnica de entrevista no momento da interpretação dos dados.

Como concluímos os trabalhos na UNICSUL no início do mês de dezembro de 2009, realizamos a pesquisa de campo na USP somente no começo de março de 2010, porém em 40 dias conseguimos concluir a coleta de dados. Inicialmente nos apresentamos em aulas de Letras e de Pedagogia e entregamos os questionários, mas sem que os alunos respondessem no momento, a pedido dos professores. Recolhemos os questionários posteriormente. Os alunos da universidade pública, portanto, tiveram uma liberdade muito maior que os da privada para responder, pois a maioria levou o questionário para casa e entregou depois, o que só foi viável devido à proximidade física entre a USP e a pesquisadora, que tinha condições de voltar em diferentes momentos para recolher os questionários. No curso de Pedagogia, tivemos 19 questionários respondidos por alunos do sexto semestre. Já no curso de Letras, o processo foi mais trabalhoso porque as turmas não são homogêneas como em Pedagogia, mesclando estudantes de diferentes semestres e habilitações, então procuramos realizar a abordagem principalmente durante a disciplina de estágio da habilitação em Inglês, já que os alunos no geral cursam também a habilitação em Português e a maioria está nos semestres finais do curso. Escolhemos ainda uma das últimas disciplinas ministradas em Português para aplicar o questionário; por essa razão o corpus de Letras na USP teve uma variação: embora a maior parte da amostra seja formada por alunos da habilitação Português/Inglês (18 pessoas), há quatro pesquisados que diferem na segunda habilitação, sendo três de Português/Espanhol e um de Português/Alemão. Optamos por não descartar esses quatro questionários porque, como nosso objetivo é investigar a formação na habilitação Português, todos se encaixam nessa proposta. Foram, portanto, 22 questionários respondidos em Letras, sendo 9 de alunos do sétimo semestre, 7 do nono, 3 do oitavo, 1 do quinto e 1 do décimo primeiro semestre. Nas entrevistas, porém, demos preferência aos alunos de Português/Inglês que cursassem também a Licenciatura, já que nosso foco são futuros professores, realizando cinco entrevistas com pessoas desse grupo. Mas fizemos também entrevista com uma das pessoas que cursam Português/Espanhol devido ao grande interesse dela pelo tema 
da pesquisa e disposição em participar, somando, assim como na UNICSUL, seis entrevistas em Letras e cinco em Pedagogia.

Além da proximidade física que facilitou a coleta de dados, a disponibilidade de tempo dos próprios alunos certamente contribuiu para a agilização, embora em alguns casos tenham sido necessárias algumas tentativas até de fato conseguir conciliar os horários. Além disso, com os alunos da USP percebemos uma abertura maior desde o início e uma postura mais à vontade diante da pesquisadora, o que certamente se explica pelo fato de pertencerem ao mesmo ambiente. Como a pesquisadora está vinculada à USP, assim como os alunos entrevistados, houve de imediato uma identificação. Embora oriundos de faculdades diferentes, todos pertenciam à mesma universidade, diferentemente do que ocorreu na UNICSUL, onde a pesquisadora era alguém totalmente externo àquele ambiente, não havendo, portanto, um elo inicial.

Os dados coletados nos 81 questionários foram transportados para uma planilha no programa Excel, onde foram tabulados e categorizados, com posterior geração de tabelas para apresentação das informações obtidas. As 16,5 horas de gravação (990 minutos) foram transcritas para que pudéssemos proceder à interpretação dos dados. Além disso, os dados secundários também foram tabulados e categorizados em planilhas, das quais geramos gráficos sobre o Ensino Superior e a formação de professores no Brasil e no Estado de São Paulo. 


\section{CAPÍtULO V - A descrição dos dados}

A terceira fase da pesquisa empírica é a descrição, que, segundo Lopes, faz a ponte entre a fase de observação dos dados e a fase da interpretação. A descrição é desenvolvida através da operação de análise descritiva e é feita em dois passos: proceder a uma manipulação dos dados e partir para procedimentos analíticos.

A manipulação dos dados é realizada por meio de procedimentos técnicos de organização, crítica e classificação das informações coletadas, de forma a assegurar o domínio sobre a massa coletada (permite identificar e selecionar fatos de significação para o tratamento analítico posterior), e conseguir conhecimento prévio das possibilidades da documentação em relação aos objetivos teóricos e práticos da investigação.

Os procedimentos analíticos visam à construção dos "objetos empíricos" e à reprodução do fenômeno nas condições de sua produção: “A construção do 'objeto empírico' vem a ser reprodução do fenômeno concreto descrito através de seus caracteres essenciais" (LOPES, 2005: 149). Esta etapa só é possível a partir das interferências obtidas pela tabulação anterior dos dados, que permite ver o fenômeno de forma organizada e sintética: “(...) o fenômeno deixa de ser percebido como algo caótico e ininteligível e passa a ser visto em seus atributos essenciais e interdependentes, isto é, sob uma forma sintética” (LOPES, 2005: 149).

Apresentamos a seguir a manipulação e análise dos dados secundários e dos dados coletados na pesquisa de campo nas universidades. 


\section{Educação superior e formação de professores no Brasil}

Como nosso objeto de estudos refere-se ao ensino superior e abrange duas universidades, uma pública e uma privada, consideramos importante que nosso corpus fosse formado não apenas pelos estudantes e cursos pesquisados, como também por dados secundários que nos ajudassem a formar um quadro sobre a educação superior no Brasil e, mais especificamente, no Estado de São Paulo, com o objetivo de melhor compreender o universo com o qual estamos trabalhando. Coletamos os dados brutos a partir do mais recente Censo da Educação Superior no Brasil ${ }^{6}$, com informações de 2008 divulgadas em 27 de novembro de 2009 pelo INEP (Instituto Nacional de Estudos e Pesquisas Educacionais Anísio Teixeira), do Ministério da Educação. Agora, na etapa da análise descritiva, procederemos à organização desses dados, procurando descrevêlos de forma comparativa entre instituições públicas e privadas, bem como estabelecer um recorte na formação de professores, foco de nosso estudo, direcionando para os cursos que estamos pesquisando, Pedagogia e Letras ${ }^{7}$.

O estudo do INEP aponta que o Brasil possui 2.252 instituições de educação superior $^{8}$, sendo que, dessas, $10 \%$ são públicas e $90 \%$, privadas.

\section{Educação superior no Brasil Total de instituições públicas e privadas}

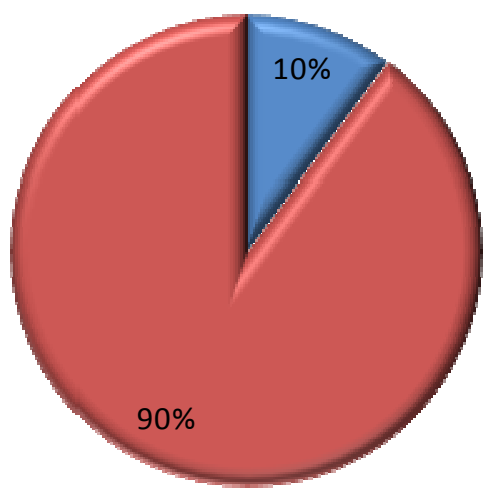

Públicas - Número total: 236

Grivadas - Número total: 2.016

Fonte: MEC/INEP/DEED - 2008

\footnotetext{
${ }^{6}$ Dados disponíveis em http://www.inep.gov.br/superior/censosuperior/sinopse/default.asp

${ }^{7}$ No caso específico de Letras, os dados apresentados referem-se apenas à Licenciatura, pois integram a área geral da Educação

${ }^{8}$ Instituições de educação superior abrangem universidades, centros universitários, faculdades e institutos de educação tecnológica.
} 
A região Sudeste é a que concentra a maior parcela desse total, com 104 instituições públicas e 965 privadas, o que representa 47\% do total existente no Brasil. Somente o Estado de São Paulo possui 537 instituições de ensino superior, ou seja, metade de toda a região Sudeste, que conta com 1.069. Na comparação com o Brasil, o Estado de São Paulo abrange $24 \%$ das instituições de educação superior: são 52 públicas e 485 privadas em São Paulo, 27\% na capital e 73\% no interior.

\section{Número de instituições públicas e privadas de educação superior por região do Brasil}

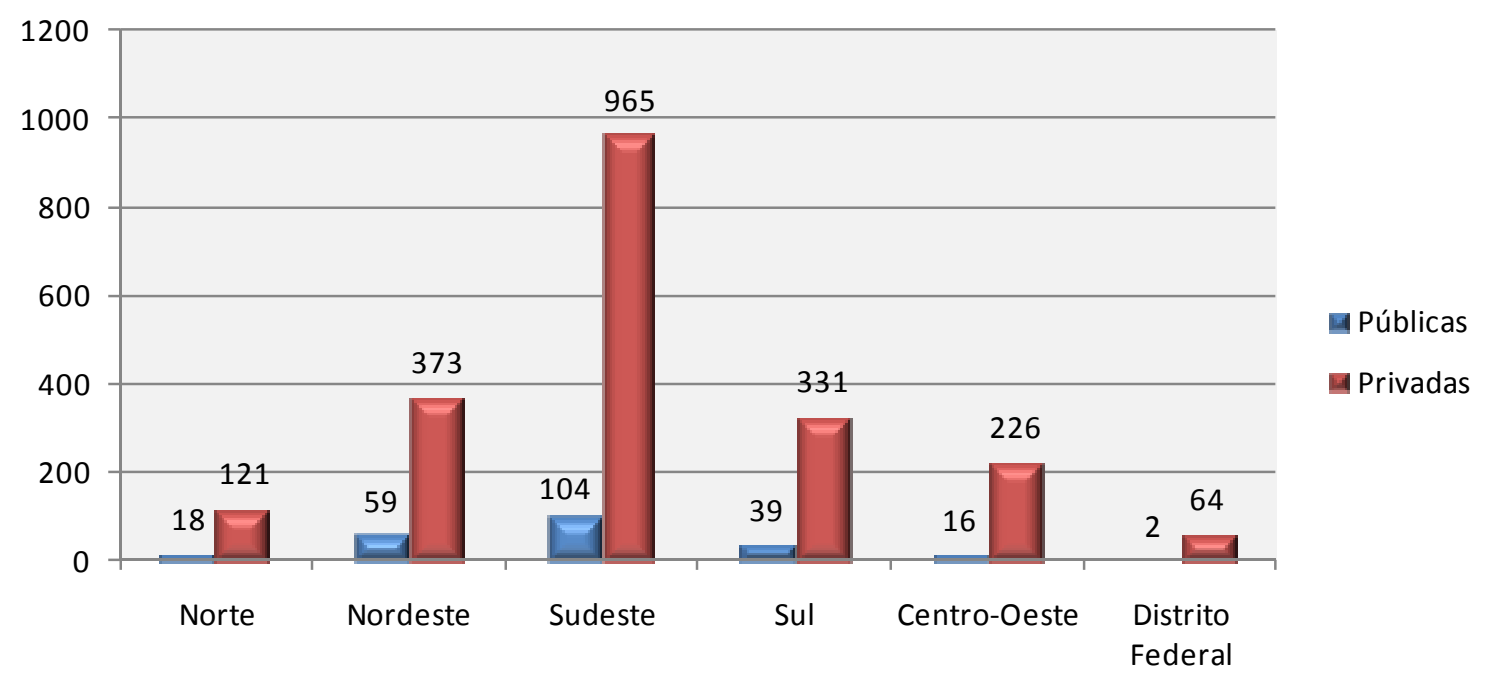

Fonte: MEC/INEP/DEED - 2008

Educação superior em São Paulo Número de instituições públicas e privadas na capital e no interior

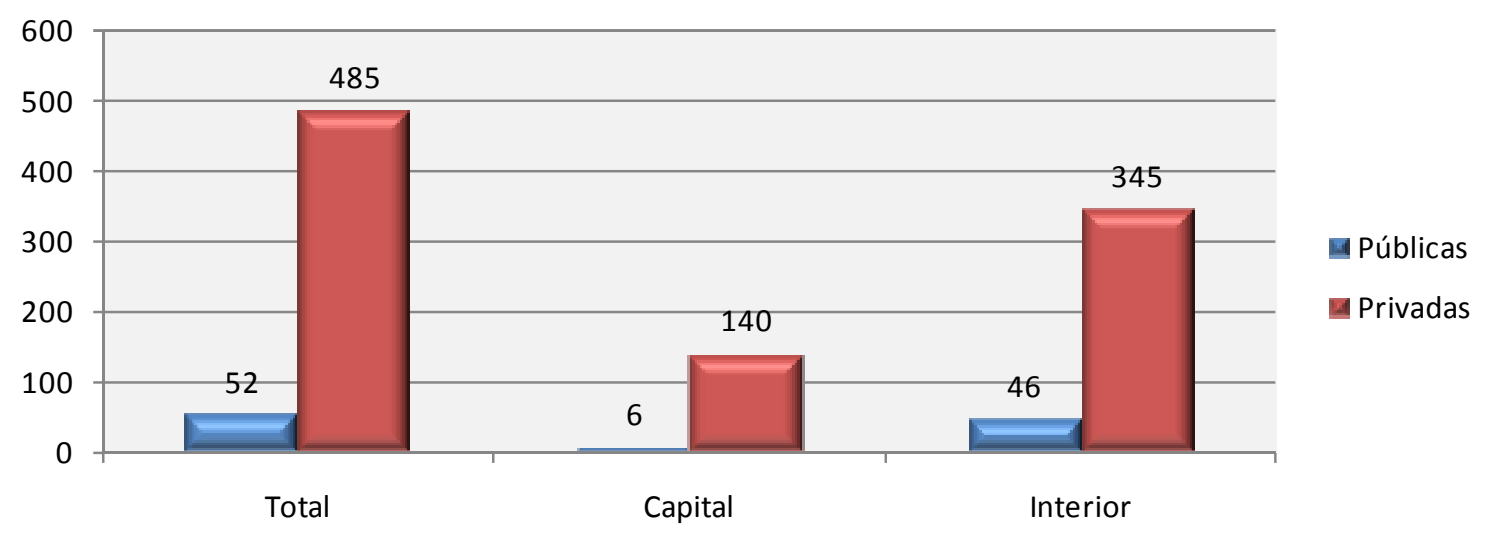

Fonte: MEC/INEP/DEED - 2008 
O número de cursos oferecidos na graduação brasileira teve uma evolução de $372 \%$ em 15 anos, passando de 5.562 cursos $^{9}$ em 1994 para 24.179 em 2008. O número de vagas, por sua vez, apresentou um crescimento ainda mais expressivo, saltando $520 \%$ no mesmo período. Em 2008, o Brasil ofereceu quase três milhões de vagas na educação superior, número alto se compararmos a 1994, quando havia 572.135 vagas, porém ainda muito aquém do número de alunos que cursam o Ensino Médio, cujo total foi de 8.272.159 em 2008, segundo dados do Censo Escolar da Educação Básica, divulgados pelo INEP em 08/03/2010 ${ }^{10}$.

\section{Evolução do número de cursos de graduação presenciais no Brasil em 15 anos - 1994 a 2008}

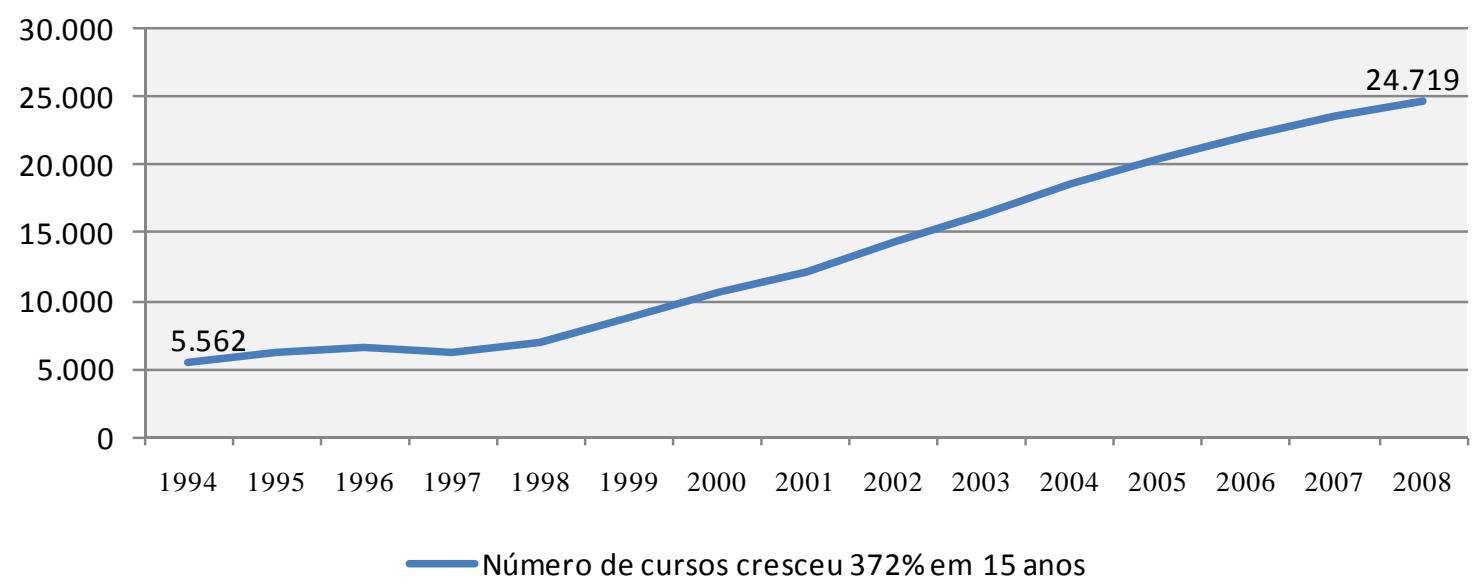

Fonte: MEC/INEP/DEED

\section{Evolução do número de vagas oferecidas no Brasil em cursos de graduação presenciais em 15 anos - 1994 a 2008}

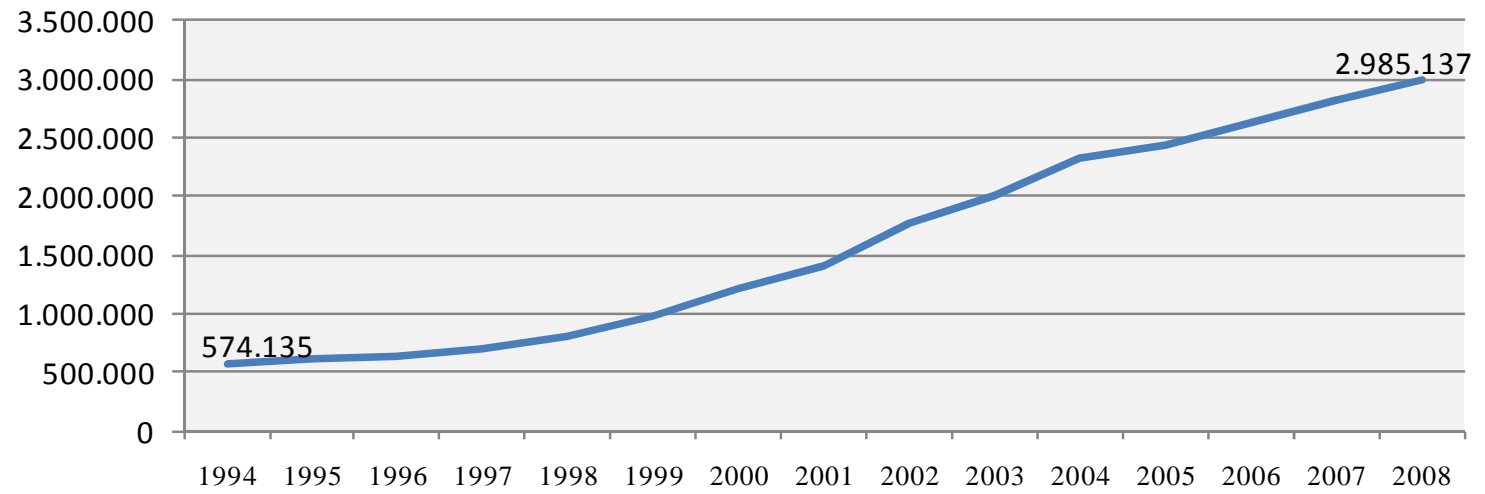

Número de vagas cresceu $520 \%$ em 15 anos

Fonte: MEC/INEP/DEED

\footnotetext{
9 Ao falar de "cursos", o estudo do Inep engloba "programas e/ou cursos de graduação". Os dados são apresentados partindo de "Áreas gerais" (por exemplo, Educação), em seguida "Áreas detalhadas" (por exemplo, Ciências da Educação), e finalmente "programas e/ou cursos" (por exemplo, Pedagogia).

${ }^{10}$ Dados disponíveis em http://www.inep.gov.br/basica/censo/Escolar/Sinopse/sinopse.asp
} 
Do total de cursos de graduação presenciais existentes em 2008, 27\% foram oferecidos por instituições públicas e $73 \%$ por privadas. No Estado de São Paulo, a parcela do ensino privado é ainda mais significativa: $88 \%$ dos cursos de graduação são pagos, somando 5.559 cursos oferecidos, contra 748 na educação superior pública.

\section{Cursos de graduação presenciais no Brasil Instituições públicas $x$ Instituições privadas}

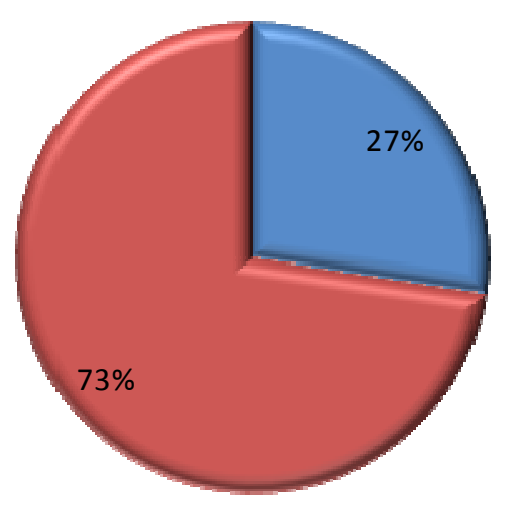

Q 6.772

Erivadas - Número total de cursos: 17.947

Fonte: MEC/INEP/DEED - 2008

\section{Cursos de graduação presenciais em São Paulo Instituições públicas x Instituições privadas}

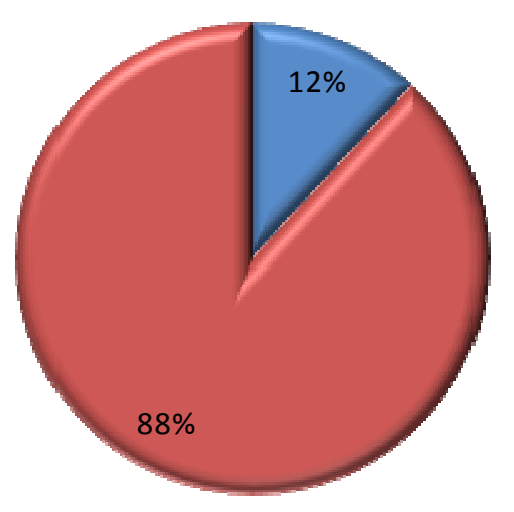

Q Públicas - Número total de cursos: 748

Q Privadas - Número total de cursos: 5.559

Fonte: MEC/INEP/DEED - 2008

Em relação especificamente à área de Educação, o Brasil ofereceu, em 2008, 6.242 cursos, representando $20 \%$ do total. E, quando fazemos a comparação entre instituições públicas e privadas, a diferença não é tão significativa quanto do total 
brasileiro: $44 \%$ dos cursos de graduação da área de Educação são oriundos de instituições públicas, e $56 \%$, de instituições privadas. Esses números diferem bastante dos apresentados anteriormente, que mostravam $73 \%$ do total de cursos de graduação no Brasil concentrados no ensino privado. Os cursos de Educação, portanto, ainda não apresentam uma predominância exaustiva do ensino superior privado.

\section{Número de cursos de Educação presenciais em relação ao número total de cursos de graduação presenciais no Brasil}

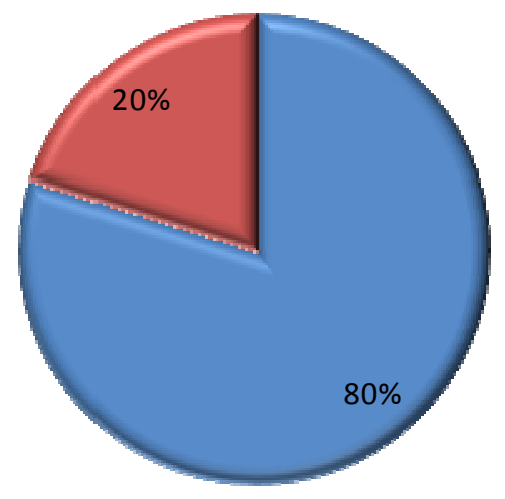

Total de cursos de graduação: 24.719

प्a Cursos de graduação da área de Educação: 6.242

Fonte: MEC/INEP/DEED - 2008

\section{Cursos de graduação presenciais da área de Educação no Brasil - Instituições públicas x Instituições privadas}

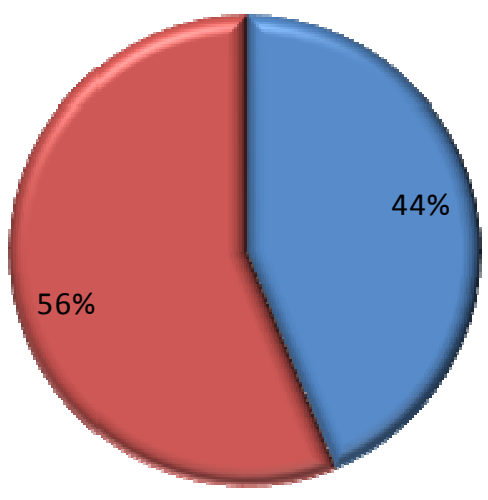

Públicas - Número total de cursos de Educação: 2.736

a Privadas - Número total de cursos de Educação: 3.506

Fonte: MEC/INEP/DEED - 2008

O estudo do INEP considera que a área geral de Educação abrange cinco áreas detalhadas: Ciências da educação (em que está incluso o curso de Pedagogia), Formação de professor da Educação Básica, Formação de professor de disciplinas profissionais, Formação de professor de educação infantil e Fomação de professor de matérias específicas (em que se incluem as Licenciaturas). O gráfico a seguir mostra a 
distribuição dessas áreas no ensino público e privado no Brasil, exibindo um dado interessante: a formação de professor de matérias específicas (de biologia, português, matemática etc) é quase que dividida pela metade entre instituições públicas e privadas, sendo que, excepcionalmente, há predominância de instituições públicas. Ou seja, embora a diferença seja pequena, existem mais cursos de formação de professor de matérias específicas no ensino público do que no privado, uma rara inversão do que ocorre na educação superior como um todo.

\section{Número de cursos de graduação prensenciais por áreas detalhadas da área geral de Educação no Brasil Instituições públicas x Instituições privadas}

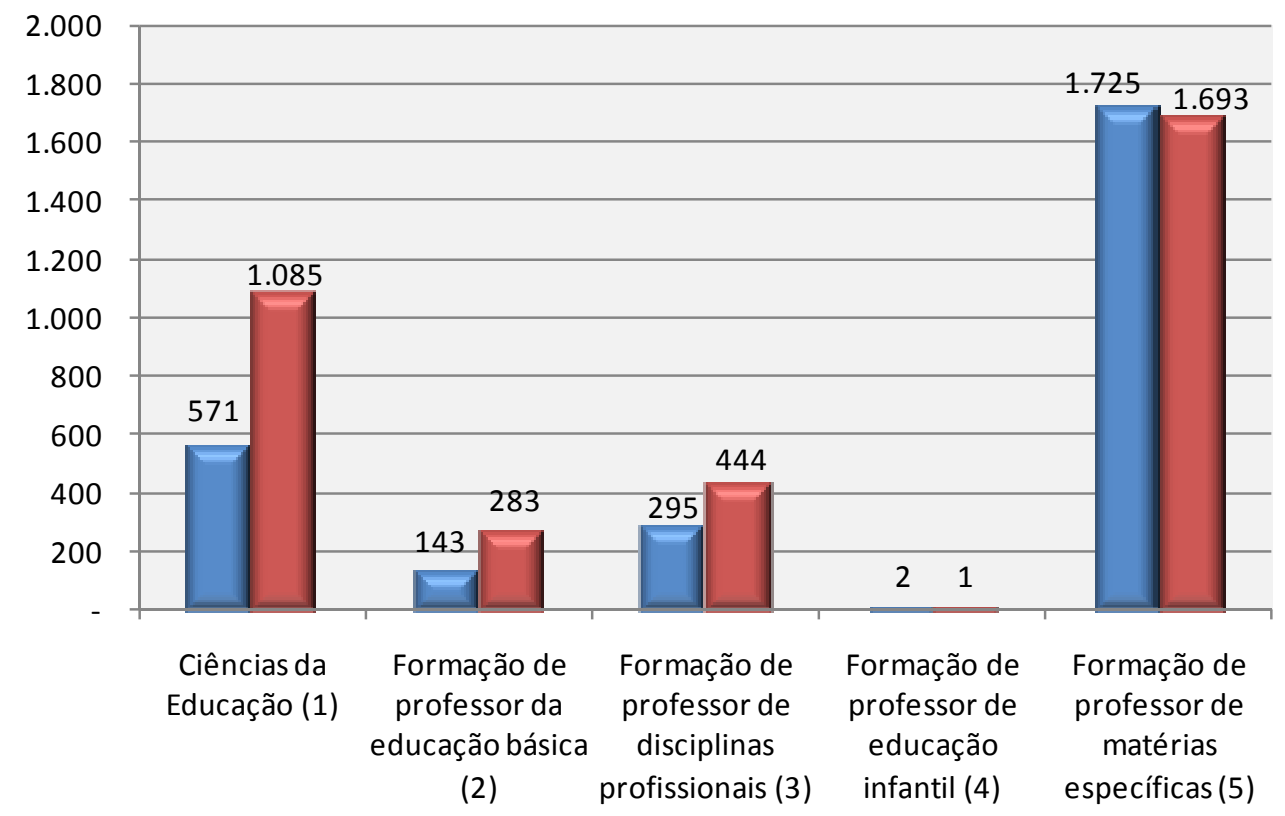

Públicas

Privadas

Fonte: MEC/INEP/DEED - 2008

(1) Administração educacional; Ciência da educação; Educação infantil; Educação organizacional; Pedagogia; Psicopedagogia.

(2) Formação de professor das séries finais do ensino fundamental; Formação de professor das séries iniciais do ensino fundamental; Formação de professor de educação artística para educação básica; Formação de professor de educação especial; Formação de professor de educação física para educação básica; Formação de professor de educação infantil e séries iniciais do ensino fundamental; Formação de professor do ensino fundamental; Formação de professor do ensino médio; Formação de professor para a educação básica; Normal superior.

(3) Formação de professor de artes (educação artística); Formação de professor de artes plásticas; Formação de professor de artes visuais; Formação de professor de computação (informática); Formação de professor de construção civil; Formação de professor de dança; Formação de professor de decoração; Formação de professor de disciplinas do setor primário (agricultura, pecuária, etc); Formação de professor de disciplinas profissionalizantes do ensino médio; Formação de professor de educação física; Formação de professor de eletricidade; Formação de professor de eletrônica; Formação de professor de eletrônica; Formação de professor de enfermagem; Formação de professor de mecânica; Formação de professor de música; Formação de professor de nutrição e dietética; Formação de professor de teatro (artes cênicas); Formação de professor em ciências ambientais; Formação de professor em segurança pública.

(4) Formação de professor de educação infantil.

(5) Formação de professor de biologia; Formação de professor de ciências; Formação de professor de desenho; Formação de professor de educação religiosa; Formação de professor de estatística; Formação de professor de estudos sociais; Formação de professor de filosofia; Formação de professor de física; Formação de professor de geografia; Formação de professor de história; Formação de professor de letras; Formação de professor de língua/literatura estrangeira moderna; Formação de professor de língua/literatura vernácula (português); Formação de professor de 
língua/literatura vernácula e língua estrangeira moderna; Formação de professor de matemática; Formação de professor de matérias pedagógicas; Formação de professor de psicologia; Formação de professor de química; Formação de professor de sociologia; Formação de professor em ciências sociais.

Ao compararmos apenas os cursos de Pedagogia e Licenciatura em Letras, no entanto, a predominância do ensino privado é evidente, especialmente no caso de Pedagogia, que está inserido na área detalhada de Ciências da Educação, onde existe uma concentração de $66 \%$ de instituições privadas. Esse curso especificamente acompanha a tendência de sua área: $65 \%$ do total é oferecido pela rede privada. O Brasil conta com 566 cursos de graduação presenciais de Pedagogia no sistema público e 1.070 no privado. Já em relação à Licenciatura em Letras, que se insere na área Formação de professores de matérias específicas, a diferença entre instituições públicas e privadas é de $10 \%$ (45\% públicas e 55\% privadas) ao considerarmos os quatro cursos ligados a Letras listados pelo INEP na área de Educação: formação de professor de Letras, formação de professor de língua/literatura estrangeira moderna, formação de professor de língua/literatura vernácula (português) e formação de professor de língua/literatura vernácula e língua estrangeira moderna. No caso dos três últimos cursos, a maioria é oferecida por instituições públicas.

\section{Número de cursos de graduação presenciais de Pedagogia e de formação de professores ligada a Letras no Brasil Instituições públicas x Instituições privadas}

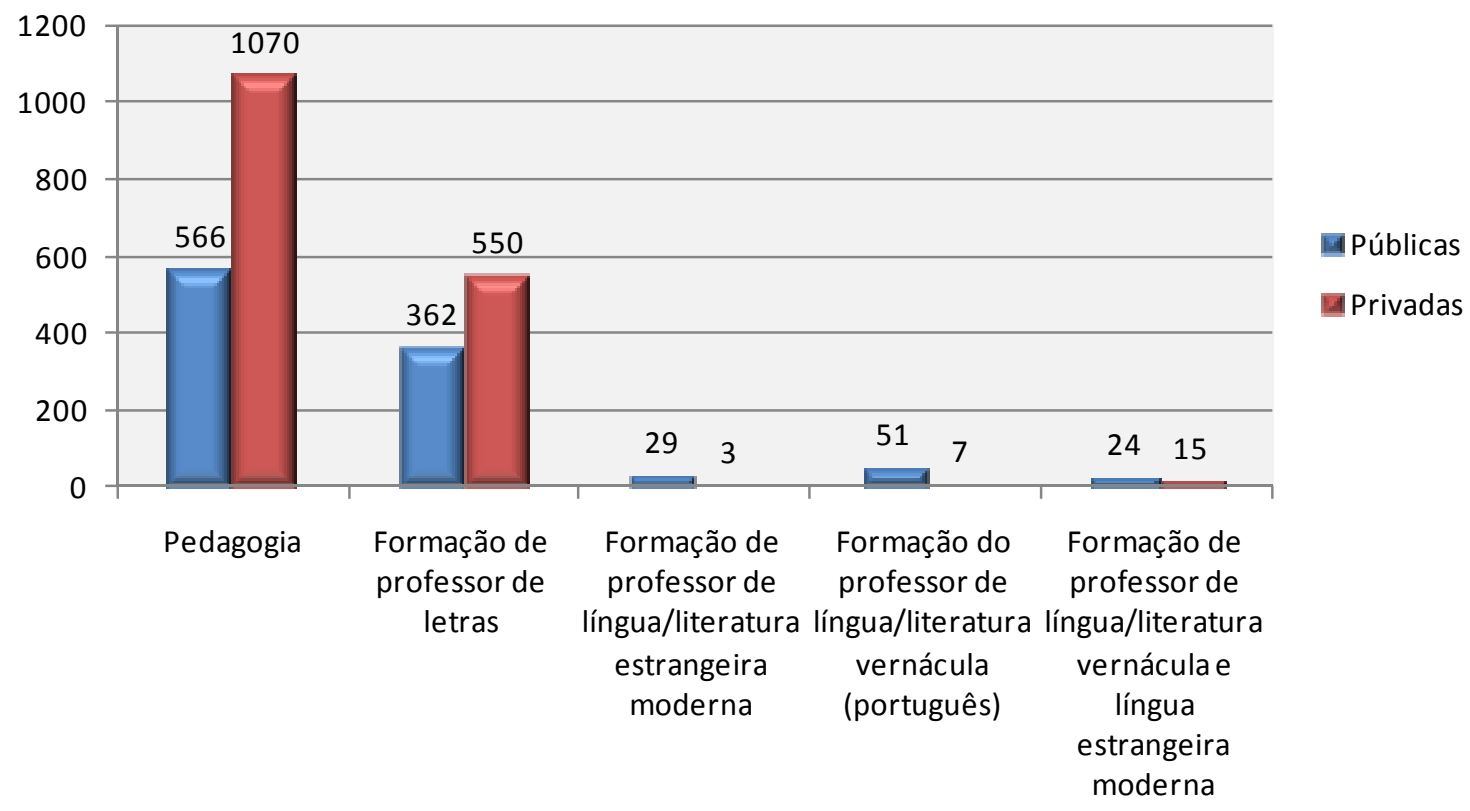


O número total de funções docentes na educação superior no Brasil é de 221.583, sendo 35\% ocupadas em instituições públicas e 65\% em instituições privadas. Vale ressaltar que, no estudo, o INEP considera que um professor pode exercer funções docentes em uma ou mais instituições.

\section{Funções docentes em exercício na educação superior no Brasil - Instituições públicas x Instituições privadas}

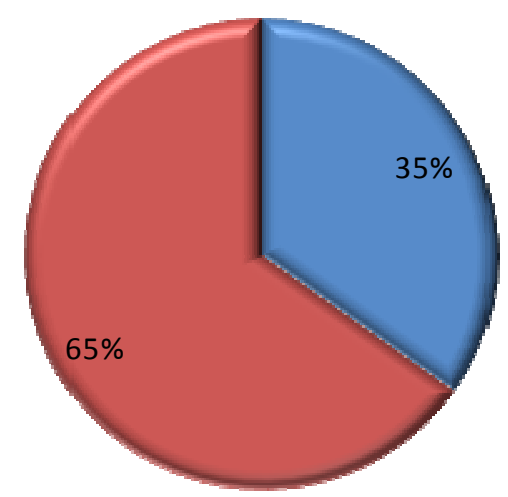

Públicas - Número total de funções docentes: 111.894

Privadas - Número total de funções docentes: 209.599

Fonte: MEC/INEP/DEED - 2008

Nota: O mesmo professor pode exercer funções docentes em uma ou mais instituições.

Ao analisarmos a formação dos profissionais que exercem as funções docentes no ensino superior no Brasil, verificamos que a grande maioria do total de 321.493 possui especialização $(30 \%)$ ou mestrado $(36 \%)$; $10 \%$ possui apenas a graduação, e 0,03\% não tem graduação (consideramos duas casas decimais nesse caso para evitar exibir 0\%). As funções docentes ocupadas por profissionais com doutorado representam 24\%, estando a maioria concentrada nas instituições públicas: $64 \%$ dos doutores ocupam funções docentes no ensino público, diferentemente do que ocorre com os outros níveis de formação superior, em que prevalece a maioria no ensino privado. 
Número de funções docentes em exercício na educação superior no Brasil por grau de formação Instituições públicas $x$ Instituições privadas

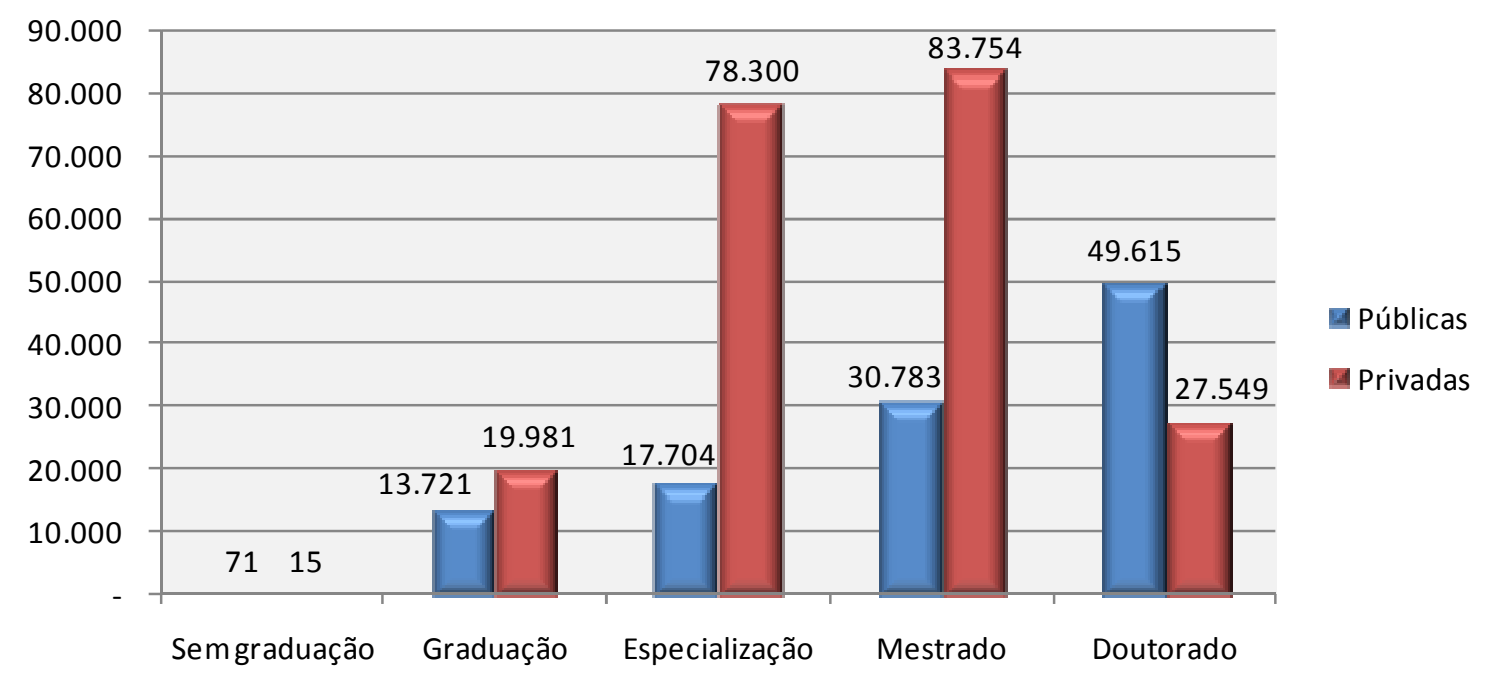

Fonte: MEC/INEP/DEED - 2008

Nota: $\mathrm{O}$ mesmo professor pode exercer funções docentes em uma ou mais instituições.

No caso do Estado de SP, o gráfico muda bastante ao compararmos instituições públicas e privadas, com uma predominância elevada de mestres e especialistas no ensino privado. Já em relação a doutores, a divisão é mais equilibrada do que aquela que abrange todo o Brasil: em São Paulo, 53\% das funções docentes ocupadas por doutores estão em instituições públicas e $43 \%$ em privadas. Ao compararmos o número de doutores no Estado em relação ao total brasileiro, São Paulo concentra $30 \%$ deles.

\section{Número de funções docentes em exercício na educação superior em São Paulo por grau de formação Instituições públicas $x$ Instituições privadas}

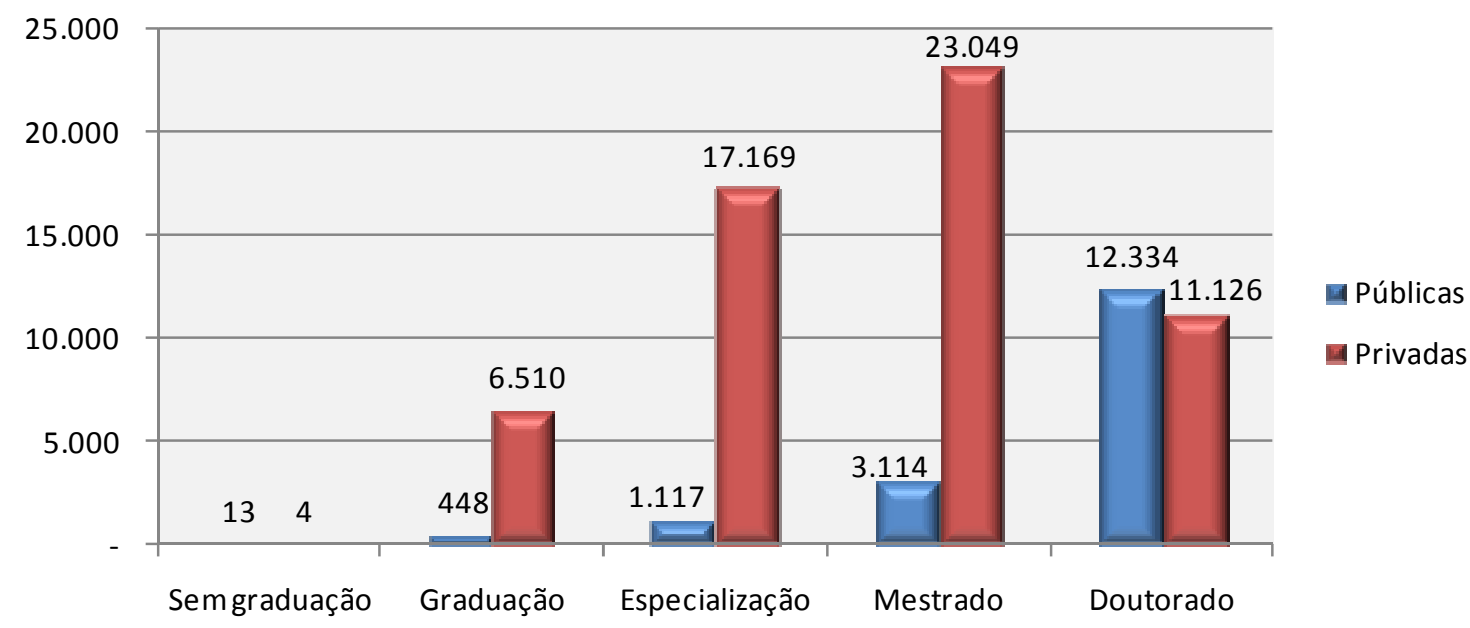


Quanto à relação matrícula/função docente, as instituições públicas no Brasil têm melhor número que as privadas, apresentando 11,4 matrículas para cada função docente, contra 18,2 das privadas. Em São Paulo, a relação se mantém quase a mesma no ensino público $(11,1)$, mas mostra-se maior no ensino privado $(20,9)$ :

\section{Relação matrículas/função docente em exercício no Brasil Instituições públicas $x$ Instituições privadas}

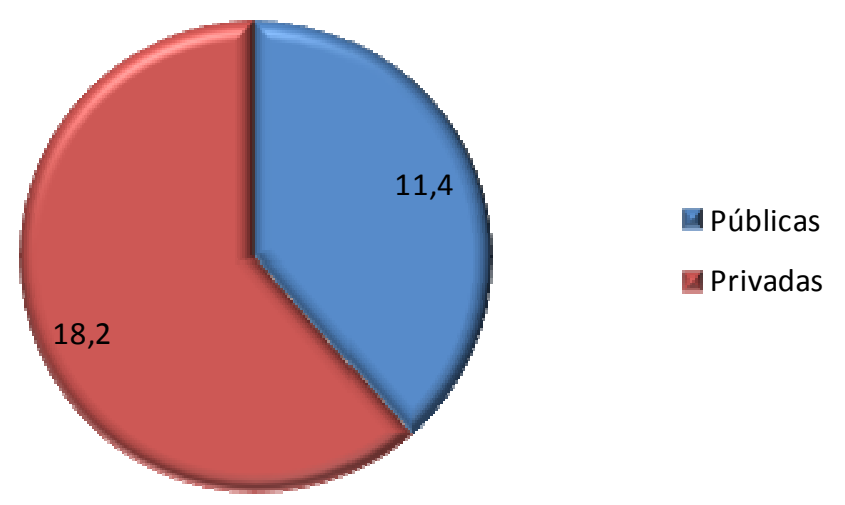

Fonte: MEC/INEP/DEED - 2008

Nota: O mesmo professor pode exercer funções docentes em uma ou mais instituições.

\section{Relação matrículas/função docente em exercício em São Paulo - Instituições públicas x Instituições privadas}

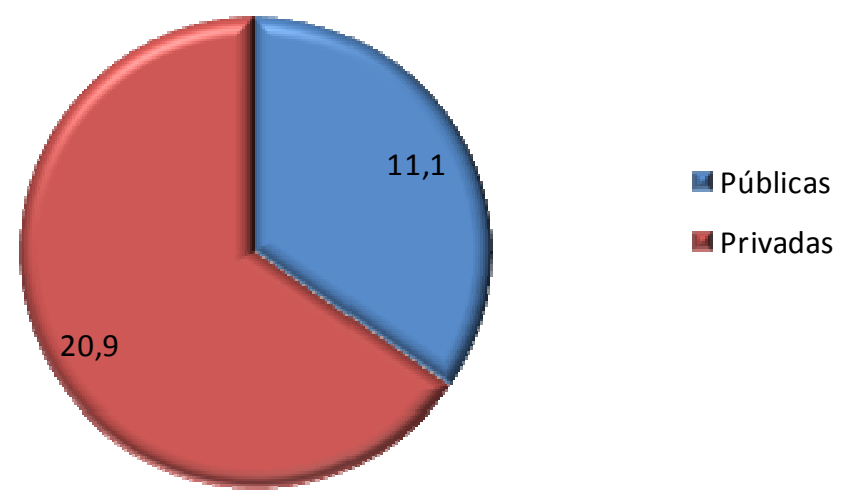

Quando comparamos o número de vagas oferecidas, o de candidatos inscritos e o de ingressos nos cursos de graduação presenciais no Brasil em 2008, nos deparamos com a grande discrepância existente no ensino público: as universidades públicas recebem um alto número de inscrições, porém somente uma parcela pequena consegue 
ingressar. Dos 2.453.661 de inscritos, apenas 307.313 entraram, ou seja, somente $13 \%$ dos alunos que tentaram vaga na universidade pública conseguiram ingressar. E nem todas as vagas foram preenchidas, pois as instituições públicas ofereceram 344.038 vagas, ficando $11 \%$ em aberto. Esse último fenômeno ocorre também na universidade particular, e com uma intensidade muito maior: 55\% das vagas oferecidas pelo ensino superior privado não foram preenchidas, pois foram ofertadas 2.641 .099 vagas e somente 1.198.506 alunos ingressaram, embora o número de inscritos tenha sido de 3.081.028. No Brasil, 88\% das vagas oferecidas são oriundas de instituições privadas e $80 \%$ dos ingressos também; já os candidatos inscritos no sistema privado representam $56 \%$ do total.

\section{Número de vagas oferecidas, candidatos inscritos e ingressos nos cursos de graduação presenciais no Brasil Instituições públicas $x$ Instituições privadas}

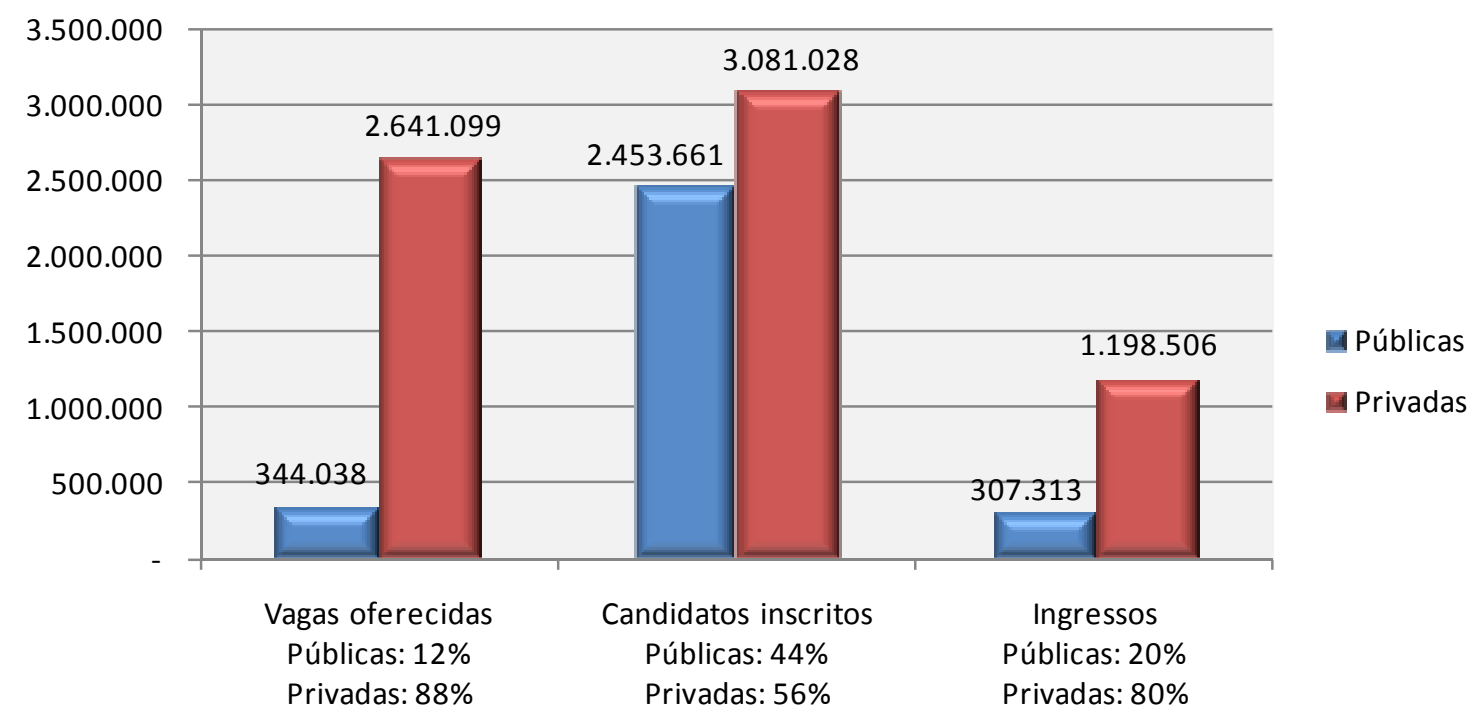

Fonte: MEC/INEP/DEED - 2008

No Estado de São Paulo, a predominância da educação superior privada fica ainda mais evidente, pois $94 \%$ das vagas oferecidas provêm de instituições particulares e $90 \%$ dos ingressos ocorrem nesse sistema. A incidência de inscrições na universidade privada também é mais elevada em São Paulo que no restante do Brasil: 72\%, contra $28 \%$ que tentam vaga na universidade pública. Aliás, no caso das instituições públicas, somente $11 \%$ dos candidatos inscritos conseguem ingressar nos cursos e, paradoxalmente, $25 \%$ das vagas não são preenchidas. Seria necessário uma avaliação mais aprofundada para apontar as causas de haver tantas vagas em aberto ao mesmo 
tempo em que o número de inscritos é alto, verificando, por exemplo, se as vagas não ocupadas concentram-se nos cursos considerados de maior dificuldade, especialmente da área de Exatas, porém esse não é objetivo de nossa pesquisa. Queremos, com os números, mostrar referências sobre o ensino superior no Brasil e no Estado de São Paulo.

\section{Número de vagas oferecidas, candidatos inscritos e ingressos nos cursos de graduação presenciais em SP Instituições públicas $x$ Instituições privadas}

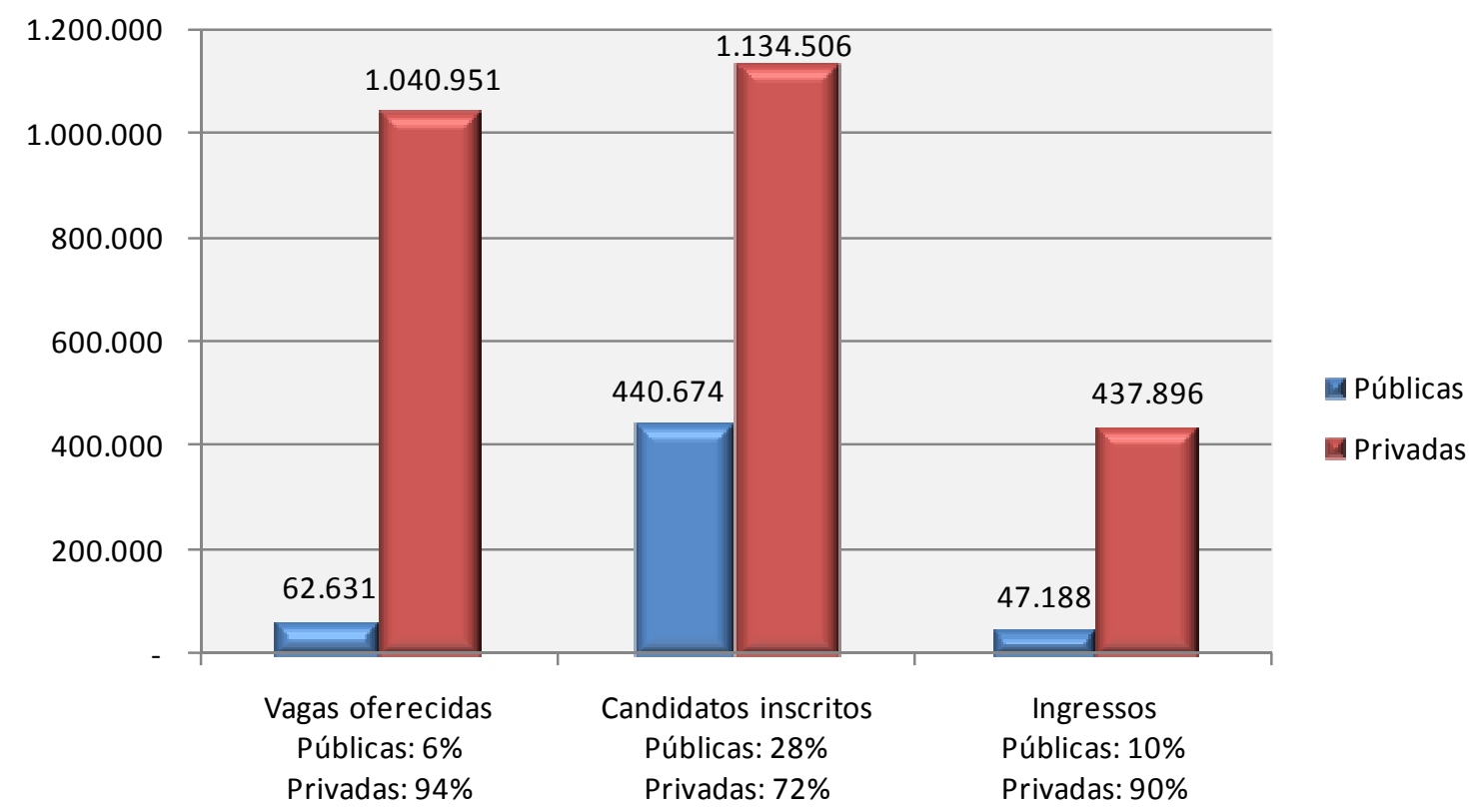

Fonte: MEC/INEP/DEED - 2008

Embora o número de ingressos na educação superior no Brasil seja menor que as vagas oferecidas, esse total vem crescendo nos últimos 15 anos, com um pico em 2002, mas uma tendência de estabilização em 2008, como mostra a curva do gráfico a seguir. De 1994 a 2008, os ingressos cresceram 325\% (enquanto que o número de vagas, como vimos anteriormente, evoluiu 520\%), saltando de 463.240 para 1.505.819. 


\section{Evolução do número de ingressos* em cursos de graduação presenciais no Brasil em 15 anos - 1994 a 2008}

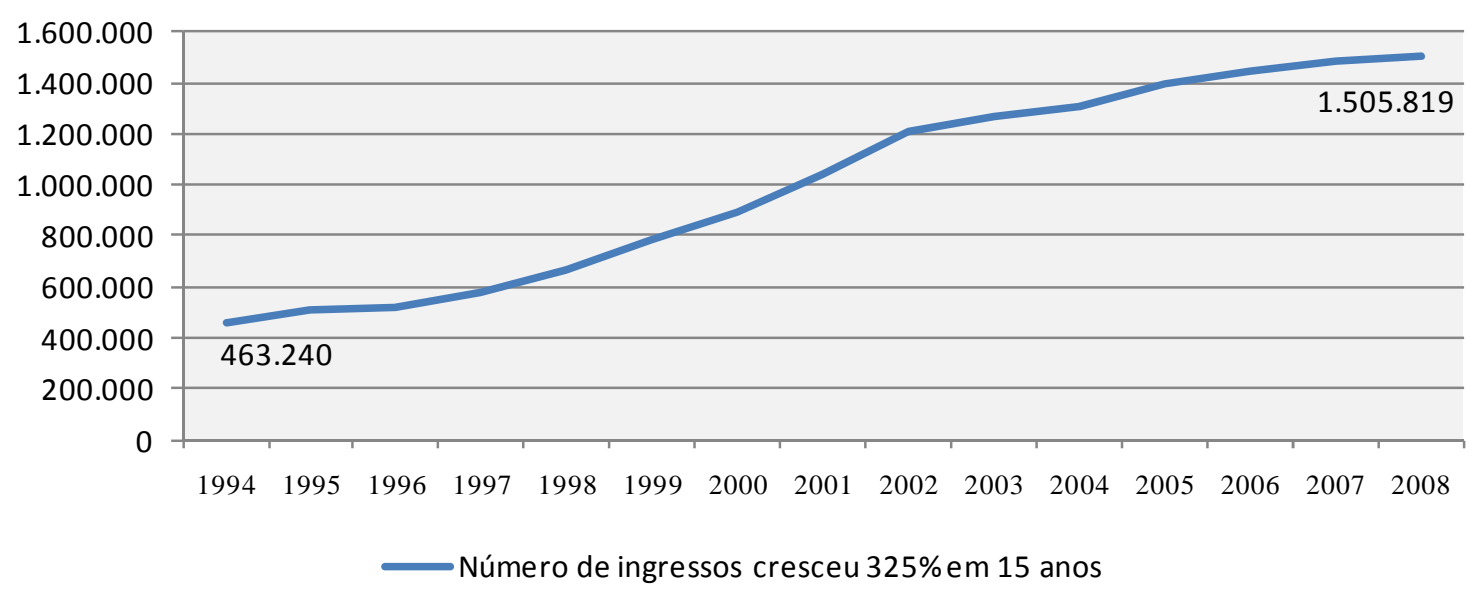

Fonte: MEC/INEP/DEED

* Ingressos por vestibular e outros processos seletivos

Ao fazermos o recorte dos dados no universo com o qual estamos trabalhando, os cursos de Pedagogia e Licenciatura em Letras, verificamos que, do total de vagas oferecidas pela área de Educação, Pedagogia representa 36\% e Letras, 17\%. Nos dois cursos, há mais candidatos inscritos que vagas, porém menos ingressos. No caso de Pedagogia, $45 \%$ das vagas foram preenchidas, e o curso representa $37 \%$ do total de ingressos na área de Educação. Já Letras teve 36\% das vagas ocupadas e representa $14 \%$ do total de ingressos dessa área.

Número de vagas oferecidas, candidatos inscritos e ingressos nos cursos de graduação presenciais da área geral de Educação e das áreas detalhadas de Pedagogia e Letras

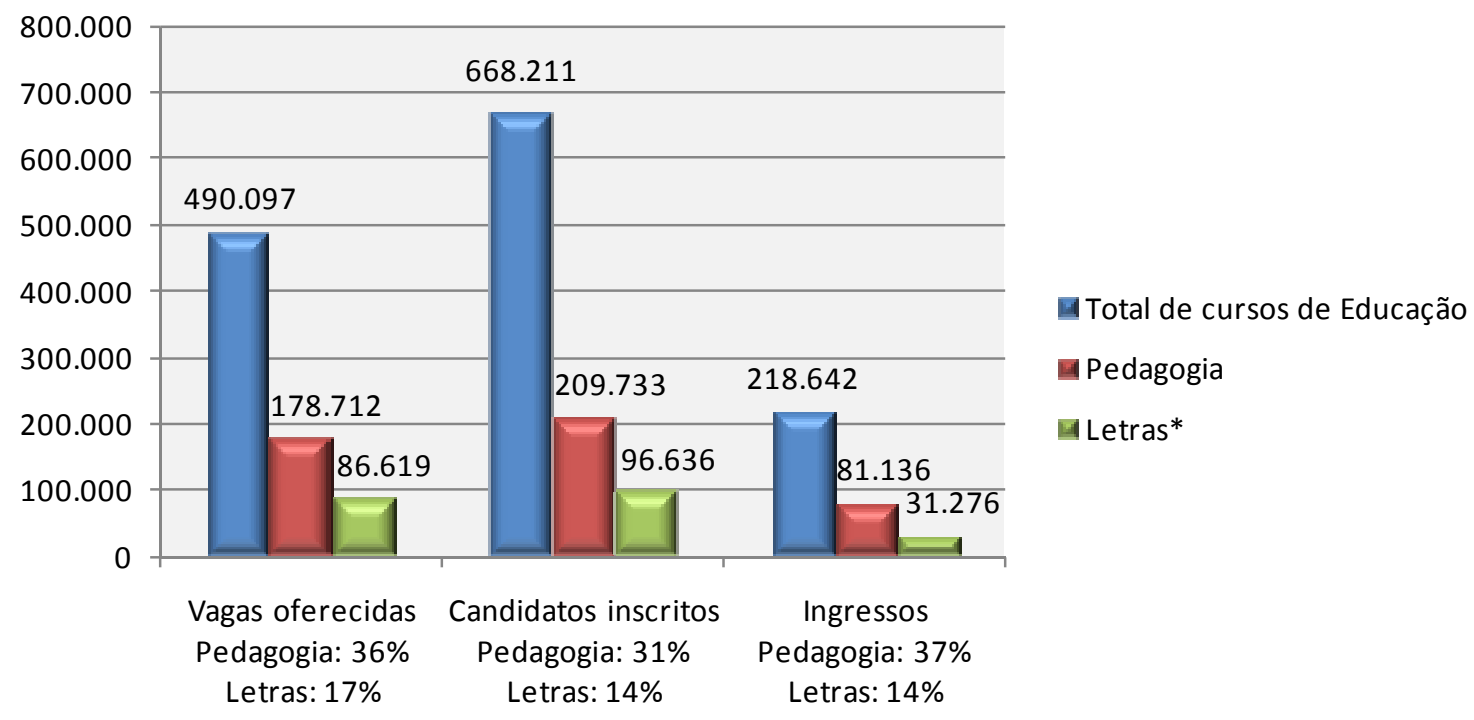

Fonte: MEC/INEP/DEED - 2008

* Inclui os cursos: Formação de professor de letras, Formação de professor de língua/literatura estrangeira moderna, Formação de professor de língua/literatura vernácula (português), Formação de professor de língua/literatura vernácula (português) e Formação de professor de língua/literatura vernácula e língua estrangeira moderna. 
Agora, passando a analisar não mais a entrada no ensino superior, e sim a conclusão, verificamos que, no Brasil, $77 \%$ dos concluintes provêm de instituições privadas e $23 \%$, de públicas. No caso específico do Estado de São Paulo, os números acompanham a tendência de uma presença ainda mais efetiva do ensino privado, com $87 \%$ dos concluintes vindos desse sistema, e $13 \%$ do público.

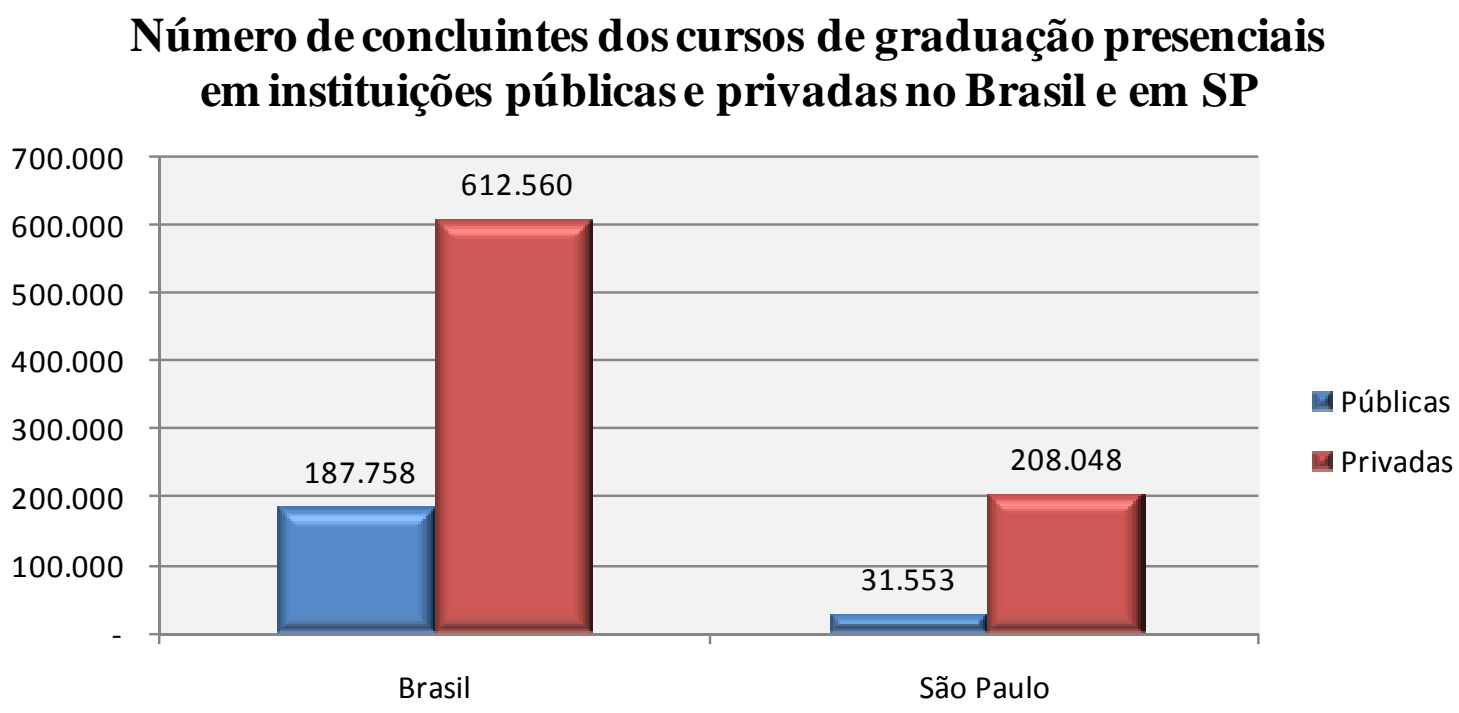

Fonte: MEC/INEP/DEED - 2008

O gráfico de evolução do número de concluintes no Brasil apresenta um pico em 2005, provavelmente resultado do pico de ingressos ocorrido em 2002, como mostrado anteriormente, e o crescimento acompanha o de ingressos: foram 325\% em 15 anos, mesmo percentual apresentado na evolução dos ingressos.

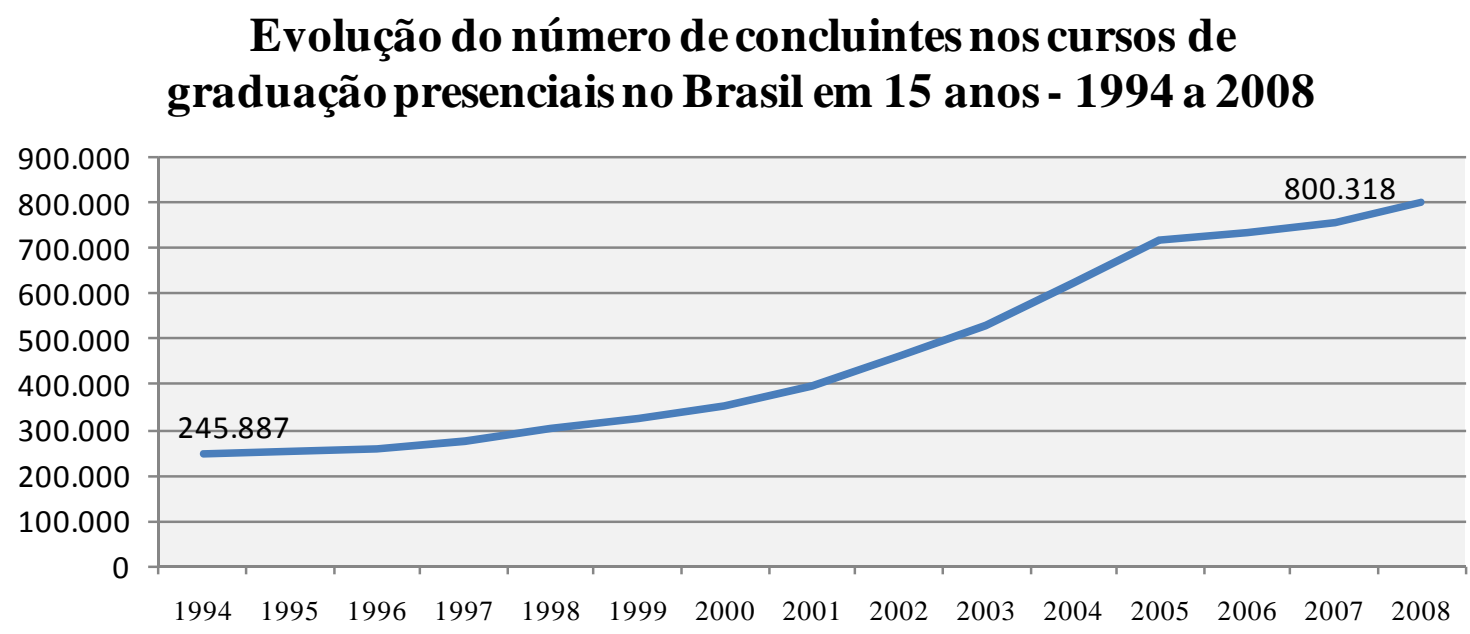

Número de concluintes cresceu $325 \%$ em 15 anos

Fonte: MEC/INEP/DEED 
A diferença, no entanto, entre o número de alunos que entra e que sai da universidade ainda é grande. Se fizermos uma comparação entre o número de ingressantes em 2005 e o de concluintes em 2008, veremos que praticamente metade conclui o curso superior. As universidades públicas apresentam um resultado melhor que as privadas, porém ambas preocupantes: $56 \%$ concluem o curso superior público, e $45 \%$ o privado. Lembramos, porém, que esses números são apenas para efeito comparativo, considerando uma duração média de quatro anos dos cursos superiores.

\section{Comparação entre número de ingressos em 2005 e número de concluintes quatro anos depois nos cursos de graduação presenciais no Brasil em instituições públicas e privadas}

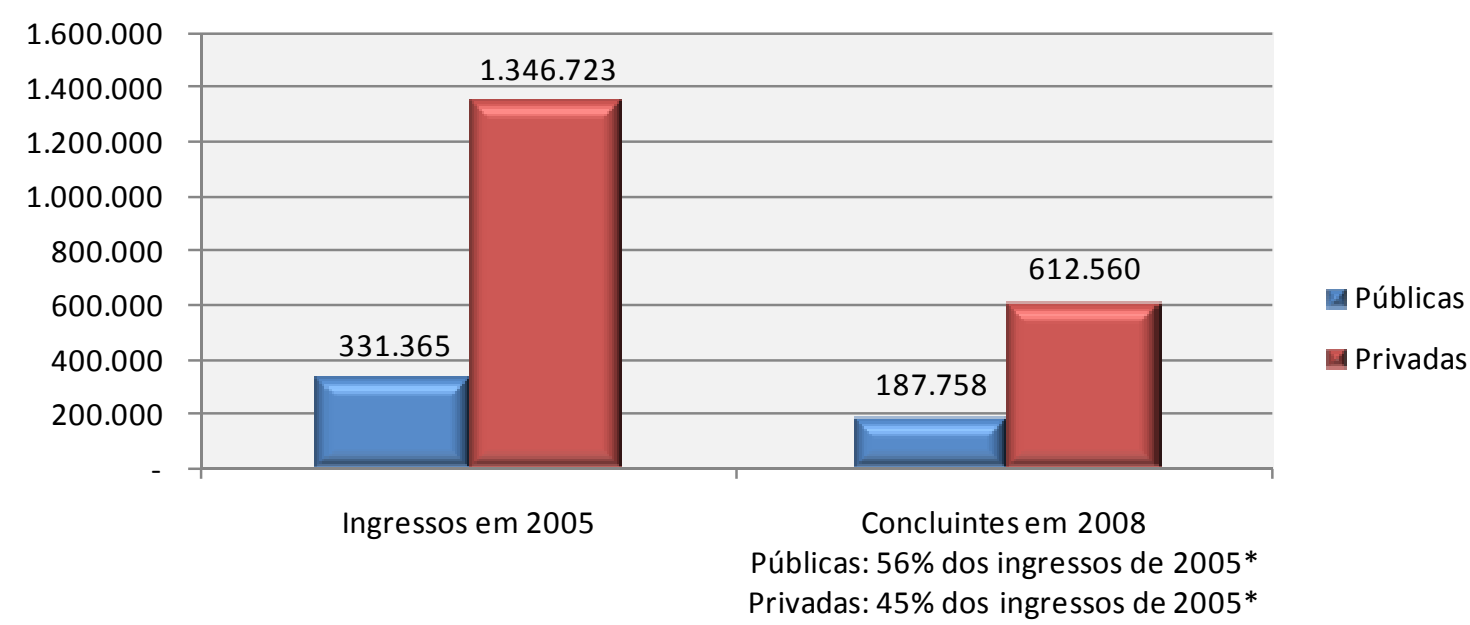

Fonte: MEC/INEP/DEED - 2008

* Percentagem apenas para efeito comparativo considerando uma média de quatro anos de duração dos cursos.

Ao fazermos a mesma comparação no Estado de São Paulo, verificamos resultados um pouco melhores: $61 \%$ concluem o curso na universidade pública, e $53 \%$ na universidade privada, mas, ainda assim, 46\% de todos os ingressantes não concluem a graduação ao considerarmos o tempo médio de quatro anos. 
Comparação entre número de ingressos em 2005 e número de concluintes quatro anos depois nos cursos de graduação presenciais em SP em instituições públicas e privadas

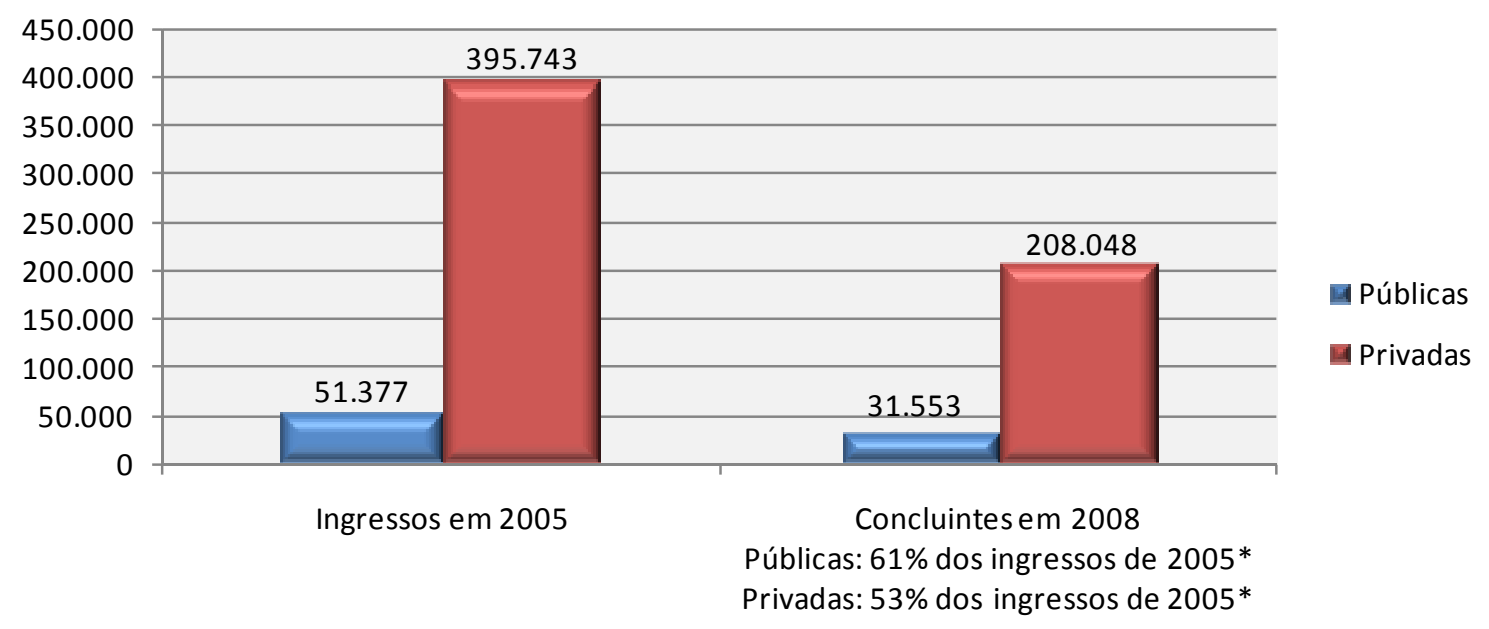

Fonte: MEC/INEP/DEED - 2008

* Percentagem apenas para efeito comparativo considerando uma média de quatro anos de duração dos cursos.

No caso dos cursos de Educação especificamente, no Brasil, os concluintes provenientes de instituições privadas somam $65 \%$, contra $35 \%$ das públicas, sendo que Pedagogia representa 33\% do total de concluintes da área de Educação, e Letras, 15\%, como mostram os gráficos a seguir.

\section{Concluintes dos cursos de graduação presenciais da área geral de Educação - Instituições públicas x privadas}

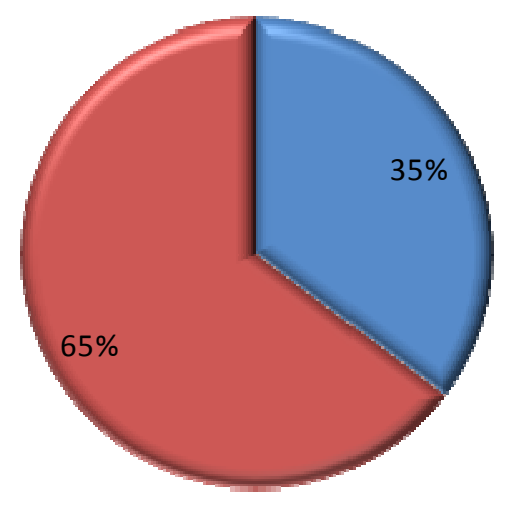




\section{Número de concluintes dos cursos de graduação presenciais da área geral de Educação e dos cursos de Pedagogia e Letras em instituições públicas e privadas}

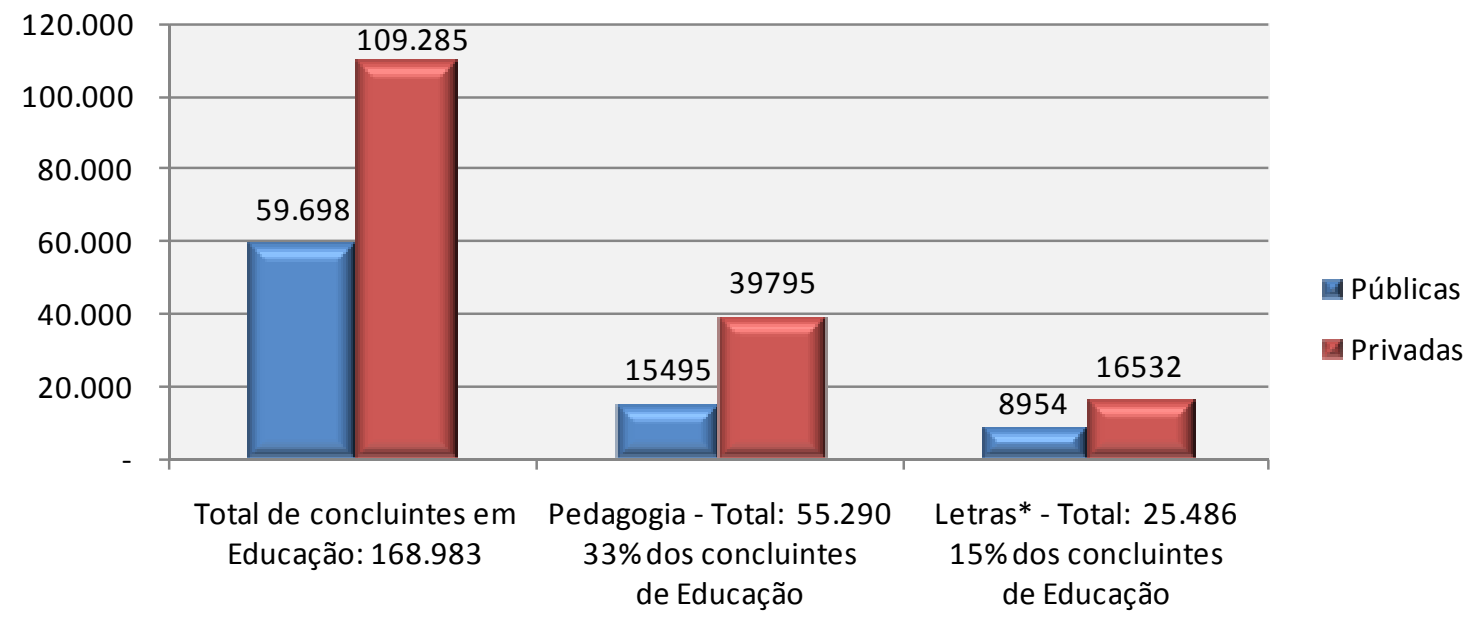

Fonte: MEC/INEP/DEED - 2008

* Inclui os cursos: Formação de professor de letras, Formação de professor de língua/literatura estrangeira moderna, Formação de professor de língua/literatura vernácula (português), Formação de professor de língua/literatura vernácula (português) e Formação de professor de língua/literatura vernácula e língua estrangeira moderna.

Embora tenhamos traçado as referências sobre a educação superior no Brasil a partir da graduação presencial, achamos importante indicar também alguns números concernentes à graduação a distância. Segundo dados do INEP, em 2008, o Brasil ofereceu 1.699.489 vagas em cursos de graduação a distância, sendo 15\% no sistema público e $85 \%$ no privado. No caso das instituições públicas, $73 \%$ das vagas foram preenchidas; já nas instituições privadas, o número de vagas preenchidas corresponde a $19 \%$. 


\section{Número de vagas oferecidas, candidatos inscritos e ingressos em cursos de graduação a distância no Brasil Instituições públicas x Instituições privadas}

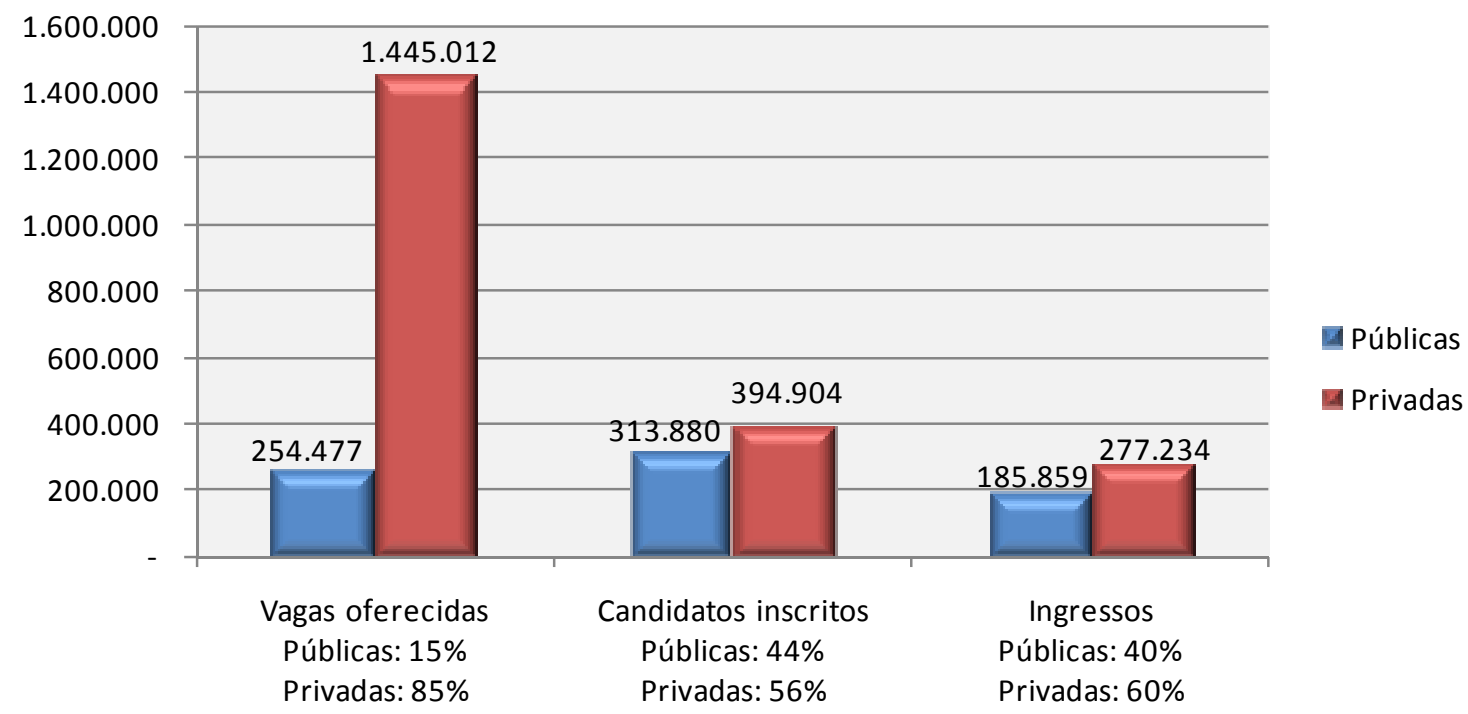

Fonte: MEC/INEP/DEED - 2008

Ao analisarmos somente o Estado de São Paulo, 99,67\% das vagas de graduação a distância foram oferecidas por instituições privadas, as quais representam $99 \%$ do total de ingressos nesses cursos. São Paulo concentra 29\% do total de vagas de ensino a distância disponíveis no país.

Número de vagas oferecidas, candidatos inscritos e ingressos em cursos de graduação a distância em SP Instituições públicas $x$ Instituições privadas

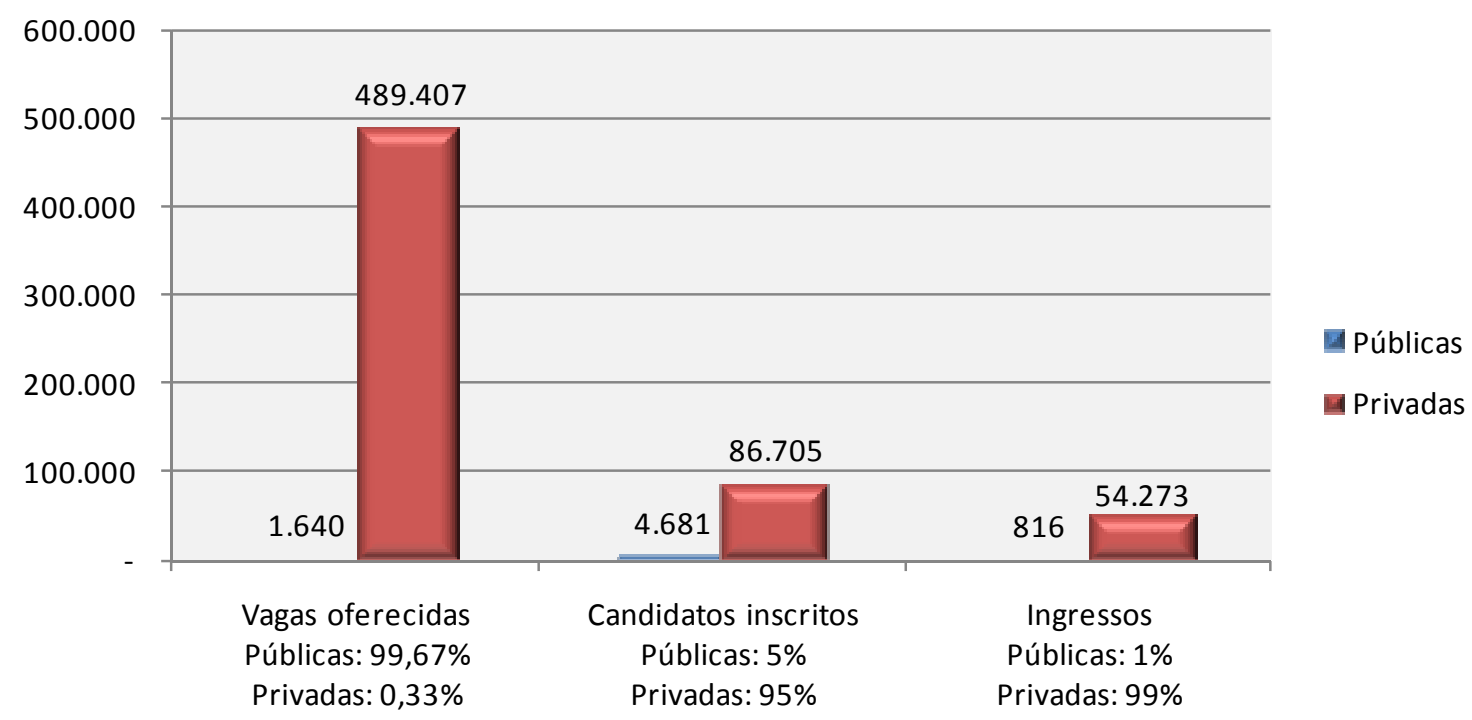


Com relação à conclusão do curso de graduação a distância, em 2008, o Brasil teve 70.068 concluintes, $12 \%$ de instituições públicas e $88 \%$ de privadas. O Estado de São Paulo contou com 9.469 concluintes, todos oriundos de instituições particulares.

Número de concluintes dos cursos de graduação a distância em instituições públicas e privadas no Brasil e em SP

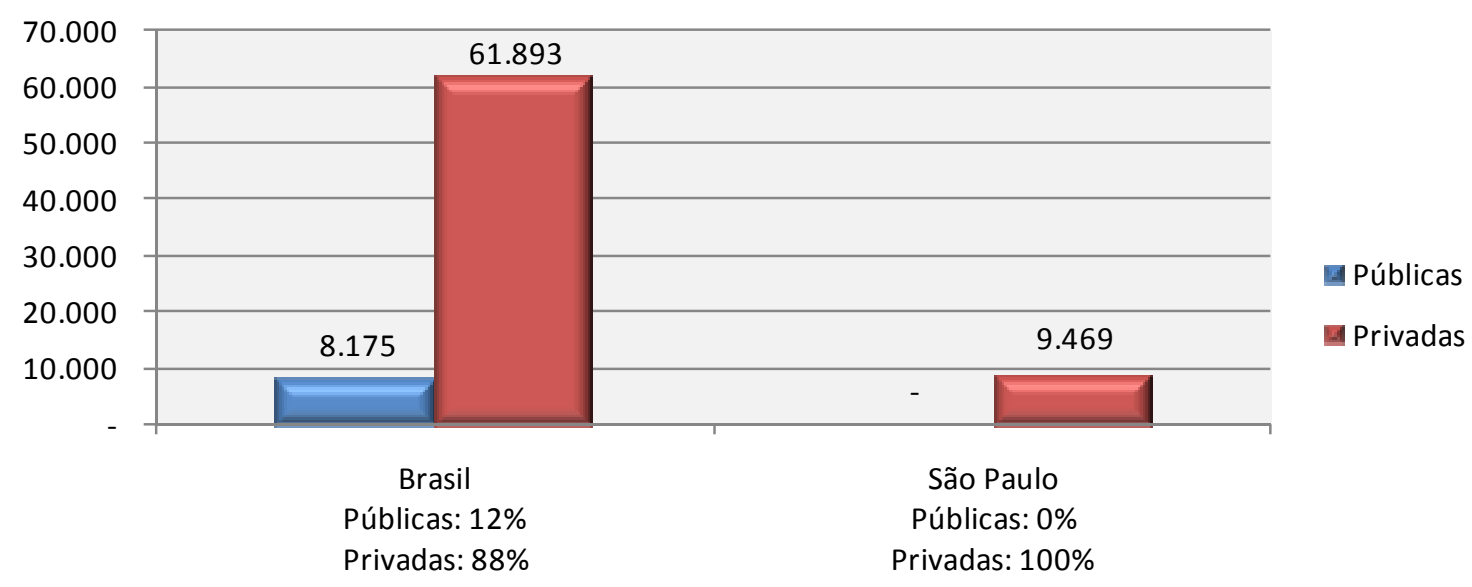

Fonte: MEC/INEP/DEED - 2008

Ao compararmos o número de vagas oferecidas pelo ensino superior presencial e pelo ensino a distância, verificamos que o primeiro representa $64 \%$ do total no Brasil, enquanto que o ensino a distância, 36\%. Em São Paulo, os números ficam em $69 \%$ e $31 \%$ respectivamente, como indicam os dois gráficos a seguir.

\section{Total de vagas oferecidas em cursos de graduação no Brasil Presenciais x A distância}

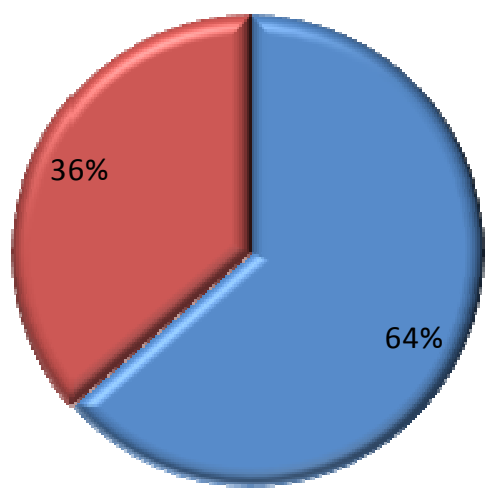

Presenciais - Total: 2.985 .137

国 A distância - Total: 1.699.489 


\section{Total de vagas oferecidas em cursos de graduação em SP Presenciais x A distância}

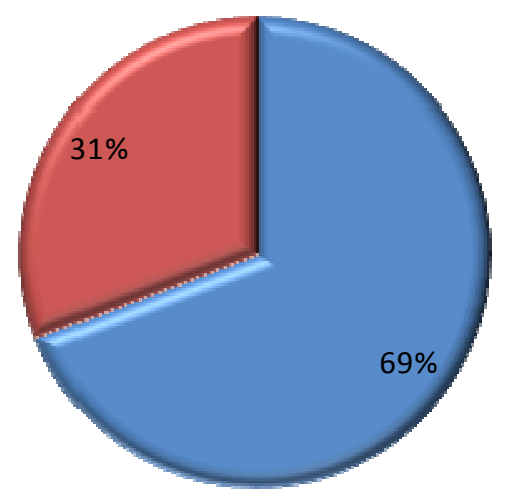

Presenciais-Total: 1.103 .582

A distância - Total: 491.047

Fonte: MEC/INEP/DEED - 2008

Já quando fazemos essa comparação em relação ao número de ingressos na educação superior, a diferença cresce: $78 \%$ ingressam no ensino presencial, enquanto que 22\% no ensino a distância no Brasil. O mesmo fenômeno ocorre em São Paulo, e de forma ainda mais acentuada: $90 \%$ dos ingressos são em cursos presenciais; os outros $10 \%$ são a distância.

\section{Total de ingressos em cursos de graduação no Brasil Presenciais x A distância}

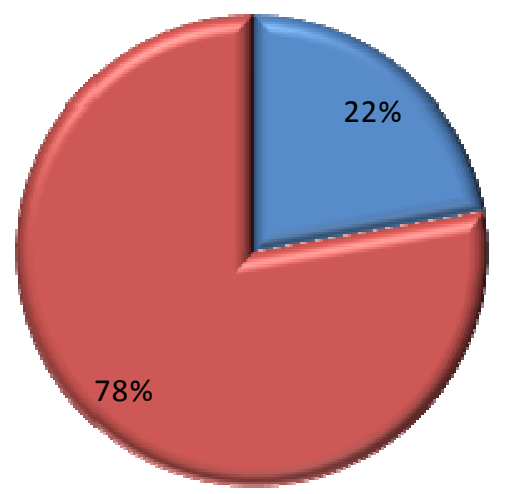




\section{Total de ingressos em cursos de graduação em São Paulo Presenciais $\mathbf{x}$ A distância}

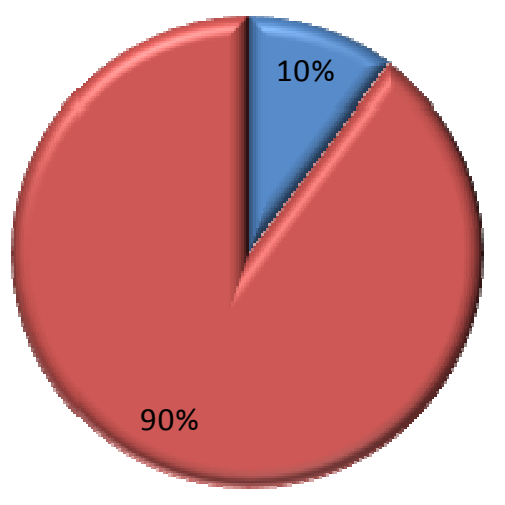

- Ingressos a distância: 55.089

Ingressos presenciais: 485.084

Fonte: MEC/INEP/DEED - 2008

Esse quadro do ensino superior e da formação de professores nos ajudou a definir panoramas de referência para nosso objeto de estudo e atualizar o debate. A partir dos dados apresentados, pudemos identificar que as instituições privadas são responsáveis pela formação da grande maioria dos graduandos brasileiros, porém os docentes mais qualificados estão concentrados nas instituições privadas de ensino superior. A área de Educação, no entanto, ainda não enfrenta uma predominância massiva de cursos oferecidos por instituições privadas, com uma incidência $12 \%$ maior de cursos de instituições privadas que públicas, número que pode ser considerado baixo se levarmos em consideração o total de cursos oferecidos no Brasil, quando a incidência de instituições privadas é $76 \%$ maior que a de públicas. No caso da formação de professores de matérias específicas, como vimos, ocorre inclusive a uma inversão dessa tendência: o número de cursos oferecidos por universidades públicas é $0,94 \%$ maior que os ofertados pelas instituições particulares.

O Estado de São Paulo, por sua vez, vive uma intensa predominância de instituições privadas, as quais representam 90\% do total de instituições de educação superior existentes no Estado. No entanto, São Paulo tem uma melhor distribuição dos docentes mais qualificados, estando $53 \%$ concentrados nas instituições públicas e $47 \%$ nas privadas, enquanto que, na média brasileira, esses números são $64 \%$ e $36 \%$, respectivamente. 


\section{Tabulação e análise descritiva dos questionários}

Partimos agora a tabulação e categorização dos dados obtidos durante a primeira etapa da pesquisa de campo (aplicação de questionário). Achamos importante em muitos momentos apresentar de forma separada as informações sobre USP e UNICSUL, de maneira a estabelecer comparações entre os perfis dos estudantes de ambas as universidades, o que contribuiu para a construção do objeto empírico e para a etapa posterior, a interpretação. Nesse primeiro momento, nossa amostra abrange 86 pesquisados, assim divididos:

Número de questionários respondidos:

\begin{tabular}{|l|c|c|c|}
\hline & UNICSUL & USP & Total \\
\hline Letras & 23 & 22 & 45 \\
\hline Pedagogia & 22 & 19 & 41 \\
\hline Total & 45 & 41 & 86 \\
\hline
\end{tabular}

Dos 86 alunos pesquisados, 73 são mulheres e 13 são homens, o que representa $85 \%$ de presença feminina. O quadro abaixo mostra a divisão por gênero e curso:

Número de alunos pesquisados por gênero:

\begin{tabular}{|l|c|r|r|}
\hline & Gênero & UNICSUL & USP \\
\hline Letras & $\mathrm{F}$ & 15 & 17 \\
& $\mathrm{M}$ & 8 & 5 \\
\hline & & & \\
\hline Pedagogia & $\mathrm{F}$ & 22 & 19 \\
& $\mathrm{M}$ & 0 & 0 \\
\hline
\end{tabular}

Nas duas universidades, portanto, a amostra é $100 \%$ feminina no caso do curso de Pedagogia. Já no curso de Letras, há uma variação: 77\% dos alunos pesquisados na USP são do sexo feminino, enquanto que, na UNICSUL, as mulheres representam $65 \%$.

Em relação à idade dos estudantes, a aplicação do questionário abrange pessoas de 19 a 53 anos, mas com concentração na faixa dos 20 aos 25 anos: 54\% das pessoas que informaram a idade enquadram-se nessa faixa. No entanto, quando dividimos a amostra de acordo com a universidade, os números mudam, com acréscimo no percentual dessa faixa etária na universidade pública, e decréscimo na universidade privada. Na USP, $68 \%$ dos pesquisados que informaram a idade têm entre 20 e 25 anos. Já na UNICSUL, 
essa faixa etária representa 41\%, com presença mais significativa de idades entre 26 e 40 anos, as quais somam $44 \%$ do total de alunos pesquisados. Na USP, esse mesmo intervalo representa $23 \%$ do total.

Faixa etária dos alunos pesquisados:

\begin{tabular}{|l|r|r|}
\hline Faixa etária & UNICSUL & USP \\
\hline Menos de 20 & 1 & 1 \\
\hline 20 a 25 & 17 & 27 \\
\hline 26 a 30 & 8 & 6 \\
\hline 31 a 35 & 6 & 2 \\
\hline 36 a 40 & 4 & 1 \\
\hline 41 a 45 & 4 & 1 \\
\hline 46 a 50 & 1 & 1 \\
\hline Mais de 50 & 0 & 1 \\
\hline Sem resposta & 4 & 1 \\
\hline Total & 45 & 41 \\
\hline
\end{tabular}

Para $85 \%$ dos estudantes pesquisados, o curso atual representa a primeira graduação, enquanto que $15 \%$ já têm outro curso superior:

Fez outro curso de graduação?

\begin{tabular}{|l|r|r|r|}
\hline & UNICSUL & USP & Total \\
\hline Não & 41 & 32 & 73 \\
\hline Sim & 4 & 9 & 13 \\
\hline
\end{tabular}

Qual curso?

\begin{tabular}{|l|r|}
\hline Ciência da Computação & 1 \\
\hline Direito & 1 \\
\hline História & 1 \\
\hline Jornalismo & 1 \\
\hline Música & 1 \\
\hline Nutrição (incompleto) & 1 \\
\hline Publicidade e propaganda & 3 \\
\hline Teologia & 2 \\
\hline Tradução/Interpretação & 1 \\
\hline Sem resposta & 1 \\
\hline Total & 13 \\
\hline
\end{tabular}

Em relação ao ofício de professor, mais da metade dos alunos pesquisados atua ou já atuou como professor, somando $52 \%$ dos que responderam à pergunta do 
questionário. Ao considerarmos esse número em cada universidade, temos $41 \%$ na instituição privada e $63 \%$ na pública.

Atua ou já atuou como professor?

\begin{tabular}{|l|r|r|r|}
\hline & UNICSUL & \multicolumn{1}{|c|}{ USP } & \multicolumn{1}{c|}{ Total } \\
\hline Não & 26 & 15 & 41 \\
\hline Sim & 18 & 26 & 44 \\
\hline Sem resposta & 1 & 0 & 1 \\
\hline
\end{tabular}

Quando observamos esse número por cursos, identificamos, no caso da UNICSUL, uma presença maior de professores em Letras: 45\%, contra $36 \%$ de Pedagogia. Já na USP, a maioria dos estudantes que já atuaram como professores está no curso de Pedagogia: 68\%, contra 59\% de Letras.

Atuação como professor por curso:

\begin{tabular}{|l|r|r|r|r|}
\hline & \multicolumn{2}{|c|}{ Unicusl } & \multicolumn{2}{c|}{ USP } \\
\hline & Total & $\%$ & Total & $\%$ \\
\hline Letras & 10 & $45 \%$ & 13 & $68 \%$ \\
\hline Pedagogia & 8 & $36 \%$ & 13 & $59 \%$ \\
\hline
\end{tabular}

Em relação ao tipo de ensino ministrado, a maioria atua no Ensino Infantil ou no Fundamental, totalizando $64 \%$. Na sequência, o ensino em escolas de idiomas também se destaca, mas com 16\%. A maioria desses profissionais encontra-se no ensino privado, como mostram os quadros a seguir:

Área de atuação dos alunos que têm alguma experiência de atuação docente:

\begin{tabular}{|l|r|}
\hline Ensino Infantil & 14 \\
\hline Ensino Fundamental & 14 \\
\hline Ensino de idiomas & 7 \\
\hline Ensino Médio & 3 \\
\hline Alfabetização de adultos & 2 \\
\hline Projetos educacionais & 2 \\
\hline Ensino profissionalizante & 1 \\
\hline Sem resposta & 1 \\
\hline Total & 44 \\
\hline
\end{tabular}


Tipo de instituição em que atuam:

\begin{tabular}{|l|r|}
\hline Escola privada & 24 \\
\hline Escola pública & 16 \\
\hline ONG & 3 \\
\hline Sem resposta & 1 \\
\hline Total & 44 \\
\hline
\end{tabular}

Do total de pesquisados que disseram já ter trabalhado como professor, 64\% continuam na ativa, enquanto $36 \%$ não dão mais aulas. $\mathrm{O}$ principal fator apontado foi a dificuldade em conciliar o trabalho com os estudos, mas também apareceram motivos como cuidar dos filhos, fim do contrato de trabalho, mudança de cidade e trauma pessoal. Como se tratava de questionário com pergunta aberta, não houve maiores explicações sobre esse último caso.

Motivos para ter deixado de dar aulas:

\begin{tabular}{|l|r|}
\hline Estudos & 9 \\
\hline Filho & 1 \\
\hline Fim do contrato & 2 \\
\hline Trauma & 1 \\
\hline Mudança & 3 \\
\hline Total & 16 \\
\hline
\end{tabular}

\subsection{Perfil socioeconômico}

Como realizamos a pesquisa com uma universidade pública, localizada na zona oeste de São Paulo, e em uma universidade privada, localizada na zona leste, achamos importante para a análise dos dados identificar aspectos socioeconômicos e também para poder conhecer melhor nossos públicos. Verificamos que a maior parte dos estudantes da UNICSUL reside no entorno da universidade, enquanto, que na USP, as localizações são bastante diversificadas, o que em geral se explica pela combinação custo/tempo: para quem cursa uma universidade gratuita, a questão do deslocamento tem um peso menor, pois não é preciso arcar com as despesas da mensalidade. Já para quem frequenta uma universidade paga, o custo com transporte causa impacto maior e ainda há a questão do tempo gasto com o trajeto, por isso a tendência é estudar em locais mais próximos de casa ou do trabalho, de forma a otimizar o dia a dia. 
Bairros de São Paulo ou cidades onde moram os pesquisados da UNICSUL:

\begin{tabular}{|l|r|}
\hline Arthur Alvim & 1 \\
\hline C.A.E. Carvalho & 1 \\
\hline Cangaíba & 1 \\
\hline Cidade Tiradentes & 2 \\
\hline Ermelino Matarazzo & 2 \\
\hline Guaianazes & 3 \\
\hline Itaim Paulista & 4 \\
\hline Itaquaquecetuba (SP) & 2 \\
\hline Jardim Cibele & 1 \\
\hline Jardim das Laranjeiras & 1 \\
\hline Jardim São Carlos & 1 \\
\hline Parque Paulistano & 1 \\
\hline Pedro José Nunes & 1 \\
\hline Penha & 2 \\
\hline São Miguel Paulista & 14 \\
\hline Vila Carrão & 1 \\
\hline Vila Ema & 1 \\
\hline Vila Regente Feijó & 1 \\
\hline Vila Silvia & 1 \\
\hline Sem resposta & 4 \\
\hline Total & 45 \\
\hline
\end{tabular}

Bairros de São Paulo ou cidades onde moram os pesquisados da USP:

\begin{tabular}{|l|r|}
\hline Barueri (SP) & 1 \\
\hline Bela Vista & 1 \\
\hline Butantã & 2 \\
\hline Cambuci & 1 \\
\hline Campinas (SP) & 2 \\
\hline Campos Elíseos & 1 \\
\hline Ermelino Matarazzo & 1 \\
\hline Higienópolis & 1 \\
\hline Itaim Paulista & 1 \\
\hline Jardim Brasília & 1 \\
\hline Jardim Colombo & 1 \\
\hline Jardim Umuarama & 1 \\
\hline Liberdade & 1 \\
\hline Mandaqui & 1 \\
\hline Morumbi & 1 \\
\hline Nova Cachoeirinha & 1 \\
\hline Osasco & 1 \\
\hline Pari & 1 \\
\hline Perdizes & 1 \\
\hline Pinheiros & 2 \\
\hline Santa Cecília & 1 \\
\hline Santo Amaro & 1 \\
\hline Santo André (SP) & 4 \\
\hline São Bernardo do Campo (SP) & 1 \\
\hline São Caetano do Sul (SP) & 1 \\
\hline São Mateus & 1 \\
\hline Tatuapé & 1 \\
\hline
\end{tabular}




\begin{tabular}{|l|r|} 
Vila Clementino & 1 \\
\hline Vila Dalila & 1 \\
\hline Vila Guilherme & 1 \\
\hline Vila Gustavo & 1 \\
\hline Vila Mangalot & 1 \\
\hline Vila Sônia & 1 \\
\hline Sem resposta & 2 \\
\hline Total & 41 \\
\hline
\end{tabular}

A distribuição geográfica dos alunos da UNICSUL é menos variada, com grande concentração no bairro de São Miguel Paulista, onde se localiza a universidade. Já na USP, a distribuição é bastante diversificada, não havendo uma concentração significativa em nenhum bairro. Os mapas das duas páginas a seguir permitem visualizar melhor a localização dos estudantes em relação às suas universidades. 


\section{Distribuição geográfica dos alunos da USP: localização mais diversificada e abrangente ${ }^{11}$}

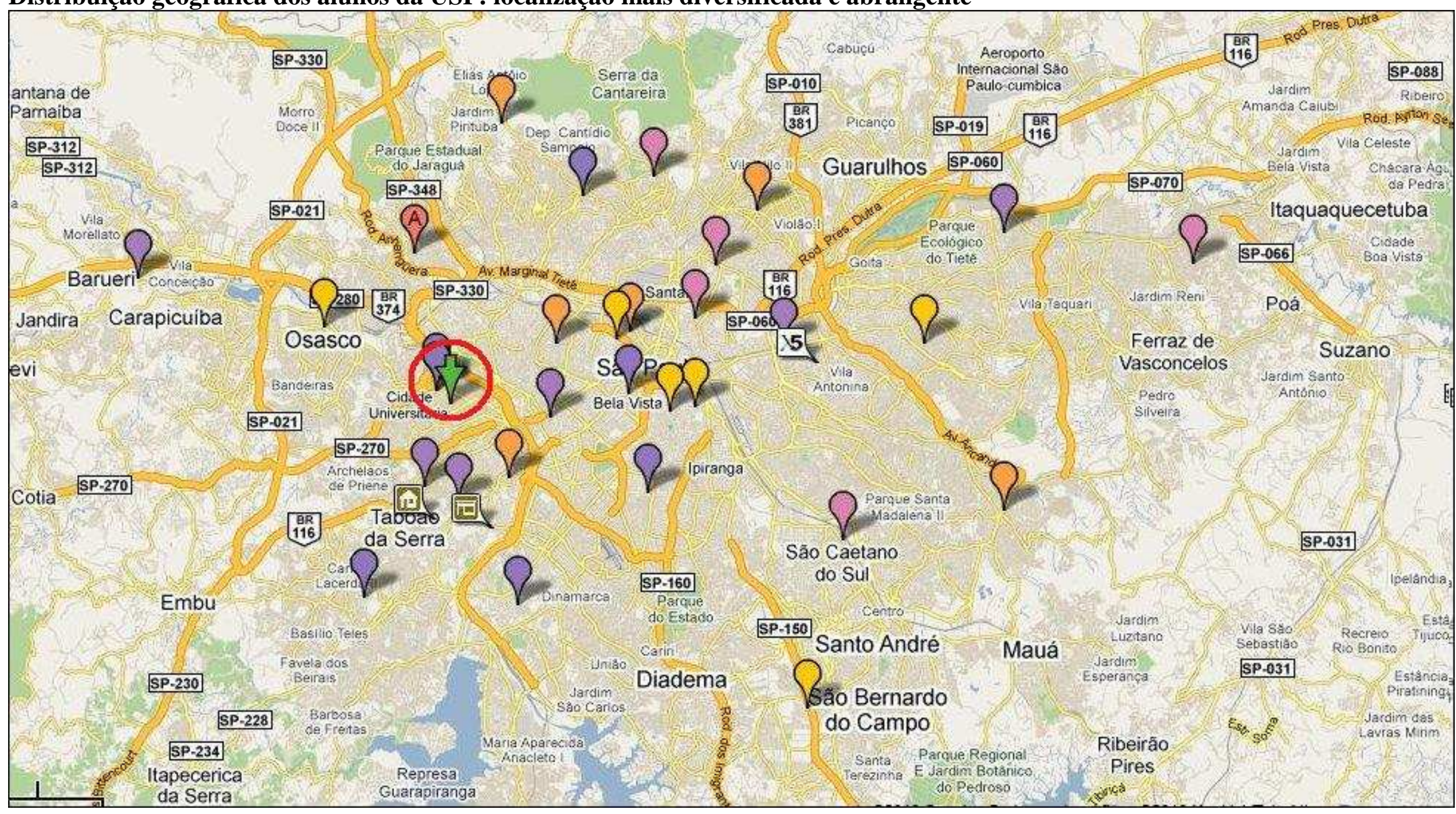

\footnotetext{
${ }^{11}$ Localização dos alunos (indicada pelos ícones coloridos) se espalha dor diversos bairros da capital, da Grande São Paulo e de cidades próximas. Somente Campinas não aparece no mapa por falta de espaço na página. Círculo em vermelho representa a USP, localizada na Cidade Universitária, bairro do Butantã, zona oeste de São Paulo.
} 
Distribuição geográfica dos alunos da UNICSUL: localização mais concentrada no entorno da universidade ${ }^{12}$

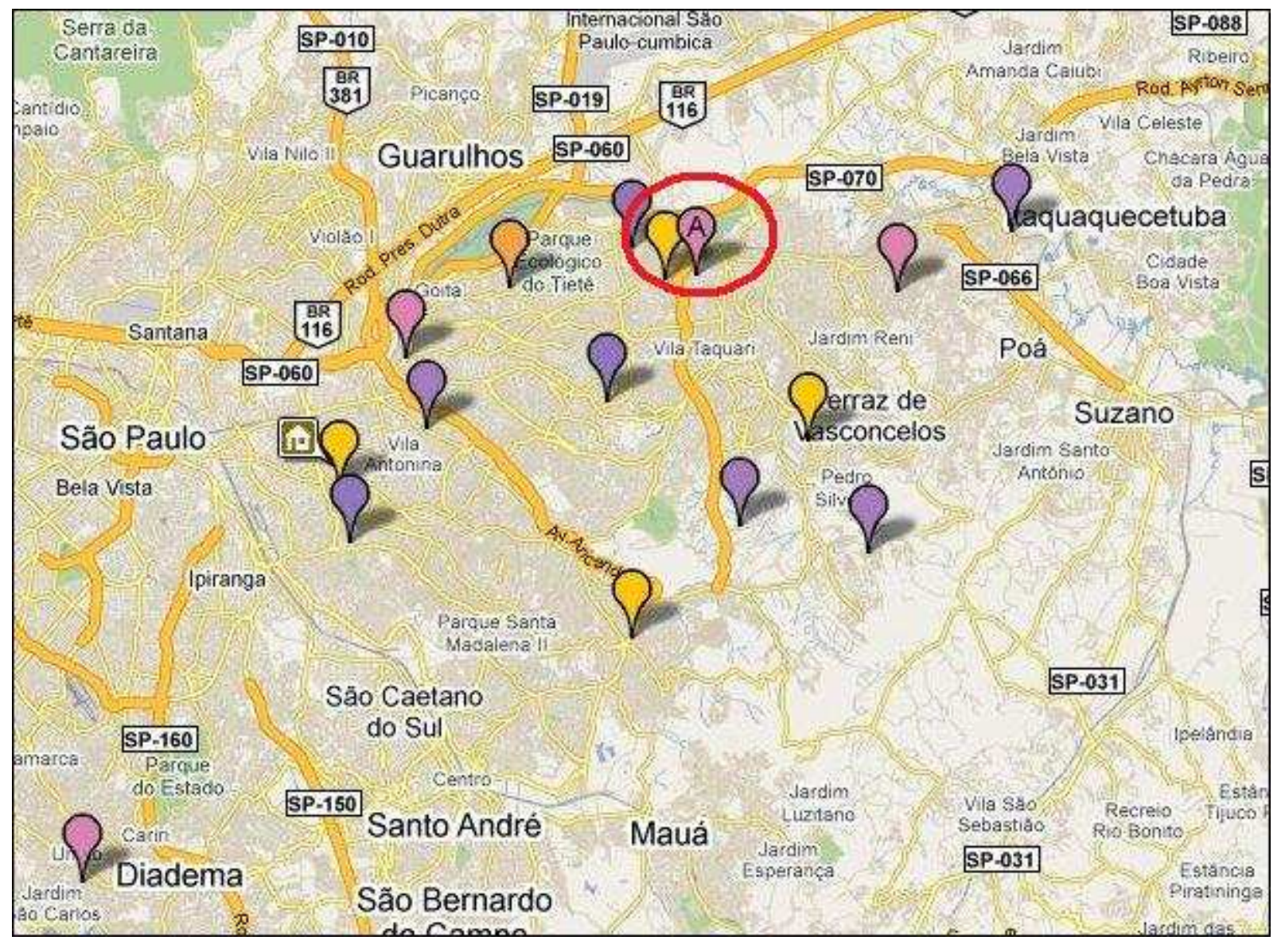

\footnotetext{
${ }^{12}$ Localização dos alunos da UNICSUL (indicada pelos ícones coloridos) é menos diversificada e mais concentrada na região da universidade. Círculo em vermelho representa a instituição, localizada no bairro de São Miguel Paulista, zona leste de São Paulo.
} 
O tipo de moradia também reflete a localização geográfica: a grande maioria (82\%) dos estudantes pesquisados da UNICSUL mora em casas, característica típica da região da zona leste, enquanto que, na USP, a maior parte vive em apartamentos (56\%), embora haja uma parcela significativa (39\%) que também mora em casas, resultado da grande diversidade de localização das moradias.

Tipo de domicílio:

\begin{tabular}{|l|r|r|}
\hline & UNICSUL & USP \\
\hline Casa & 37 & 16 \\
\hline Apartamento & 7 & 23 \\
\hline Sem resposta & 1 & 2 \\
\hline Total & 45 & 41 \\
\hline
\end{tabular}

O número de pessoas que residem no mesmo domicílio foi parecido entre as duas universidades, com concentração nas opções de três e quatro. Na UNICSUL, a maior parte $(40 \%)$ vive em residências ocupadas por quatro pessoas; em segundo lugar, ficaram as ocupadas por três pessoas (24\%). Na USP, a maior parcela dos pesquisados ficou igualmente dividida entre três e quatro: $29 \%$ vivem em três pessoas na mesma casa, e outros 29\%, em quatro. Somente na USP houve quem morasse sozinho e também nessa universidade um dos pesquisados afirmou morar em 20 porque vive em uma pensão.

Quantidade de pessoas que moram em seu domicílio: (Questão aberta)

\begin{tabular}{|l|r|r|}
\hline & UNICSUL & \multicolumn{1}{|c|}{ USP } \\
\hline Uma & 0 & 1 \\
\hline Duas & 7 & 7 \\
\hline Três & 11 & 12 \\
\hline Quatro & 18 & 12 \\
\hline Cinco & 4 & 4 \\
\hline Seis & 2 & 3 \\
\hline Sete & 2 & 0 \\
\hline Vinte & 0 & 1 \\
\hline Sem resposta & 1 & 1 \\
\hline Total & 45 & 41 \\
\hline
\end{tabular}

Em relação à situação conjugal, embora em ambas as universidades a maioria da amostra seja formada por pessoas solteiras, o número de casados foi bem mais 
expressivo na UNICSUL, onde os solteiros representam $60 \%$, e os casados e que moram com companheiro somam 38\%. Já na USP, os solteiros representam 83\%, e os casados, $15 \%$, número bem abaixo daquele apresentado na universidade privada. A média de idade pode explicar essa diferença. Como vimos anteriormente, $44 \%$ dos pesquisados da UNICSUL têm entre 26 e 40 anos, contra 23\% na USP.

Situação conjugal:

\begin{tabular}{|l|r|r|}
\hline & UNICSUL & \multicolumn{1}{|c|}{ USP } \\
\hline Solteiro(a) & 27 & 34 \\
\hline Casado(a) & 16 & 6 \\
\hline Mora com companheiro(a) & 1 & 0 \\
\hline Sem resposta & 1 & 1 \\
\hline Total & 45 & 41 \\
\hline
\end{tabular}

A pergunta sobre filhos segue a mesma tendência, isto é, o número de pessoas com filhos é bem mais expressivo na UNICSUL: $36 \%$ dos estudantes pesquisados têm filhos, contra $10 \%$ da USP.

Tem filhos?

\begin{tabular}{|l|r|r|}
\hline & UNICSUL & \multicolumn{1}{|c|}{ USP } \\
\hline Sim & 16 & 4 \\
\hline Não & 27 & 36 \\
\hline Sem resposta & 2 & 1 \\
\hline Total & 45 & 41 \\
\hline
\end{tabular}

Entre os que responderam "sim" à questão anterior, 69\% dos pesquisados da UNICSUL afirmam ter dois filhos, 19\% têm um filho e 13\% têm três filhos. Na USP, $50 \%$ afirmam ter um filho e $50 \%$, três filhos.

Quantos filhos? (Questão aberta)

\begin{tabular}{|l|r|r|}
\hline & UNICSUL & USP \\
\hline Um filho & 3 & 2 \\
\hline Dois filhos & 11 & 0 \\
\hline Três filhos & 2 & 2 \\
\hline Total & 16 & 4 \\
\hline
\end{tabular}


As respostas sobre quem seria o chefe da família, uma questão aberta, condizem com a situação conjugal dos pesquisados. Na UNICSUL, 31\% (a maior parcela) afirmam que o marido é o chefe da família. Na USP, essa mesma opção representa apenas $7 \%$, sendo que a maior parte dos estudantes da universidade pública (44\%) apontou o pai como o chefe. A mãe representa apenas $12 \%$ na USP, mesmo percentual dos que responderam "pai e mãe". Já na UNICSUL, o número dos que disseram que o pai é o chefe da família é exatamente igual ao dos que disseram que é a mãe quem faz esse papel, com $24 \%$ cada. Apenas $2 \%$ da UNICSUL disseram "pai e mãe". Houve também os que afirmaram que eles mesmos são os chefes de família (11\% na UNICSUL e 5\% na USP) e os que declararam que eles e o marido ou a esposa fazem esse papel (2\% nas duas universidades). Na UNICSUL, um dos pesquisados apontou ainda a avó como a chefe de família, o que representa $2 \%$ da amostra da universidade.

Quem é o chefe da família? (Questão aberta)

\begin{tabular}{|l|r|r|}
\hline & UNICSUL & USP \\
\hline Avó & 1 & 0 \\
\hline Mãe & 11 & 5 \\
\hline Marido & 14 & 3 \\
\hline O casal & 1 & 1 \\
\hline O mesmo & 5 & 2 \\
\hline Pai & 11 & 18 \\
\hline Pai e mãe & 1 & 5 \\
\hline Sem resposta & 1 & 7 \\
\hline Total & 45 & 41 \\
\hline
\end{tabular}

A escolaridade do chefe da família ficou concentrada em ensino superior completo nas duas universidades, mas com percentual maior na USP (46\%). Na UNICSUL, esse grau de formação representa 36\%. Embora a USP tenha mais chefes de família com ensino superior completo, quando se trata de pós-graduação, a situação se inverte, ficando a UNICSUL à frente, mas com uma pequena diferença: os chefes de família de $7 \%$ dos estudantes da universidade privada têm pós-graduação, contra $5 \%$ da pública. No entanto, a maior diferença entre as duas universidades ocorre na escolaridade relativa ao Ensino Fundamental, pois, na USP, apenas um chefe de família (2\%) não completou esse nível, enquanto que todos os outros foram além. Não há, portanto, nenhum formado apenas no Ensino Fundamental. Já na UNICSUL, 18\% dos chefes de família pertencem a essa categoria e $13 \%$ não chegaram a completar o Ensino Fundamental: 
Escolaridade do chefe da família: (Questão aberta)

\begin{tabular}{|l|r|r|}
\hline & UNICSUL & USP \\
\hline Ensino médio & 8 & 6 \\
\hline Ensino médio incompleto & 0 & 1 \\
\hline Fundamental & 8 & 0 \\
\hline Fundamental incompleto & 6 & 1 \\
\hline Pós-graduação & 3 & 2 \\
\hline Superior & 16 & 19 \\
\hline Superior incompleto & 1 & 4 \\
\hline Sem resposta & 3 & 8 \\
\hline Total & 45 & 41 \\
\hline
\end{tabular}

Em relação à etnia, adotamos a mesma classificação usada pelo IBGE (Instituto Brasileiro de Geografia e Estatística) e verificamos que nas duas universidades a maioria dos pesquisados se declarou de etnia branca, embora na universidade pública o percentual tenha sido maior: $78 \%$, contra $62 \%$ da particular. Os que se declararam pardos somam $18 \%$ na UNICSUL e $12 \%$ na USP, e amarelos somam $7 \%$ na UNICSUL e $2 \%$ na USP. Já em relação à etnia preta, a UNICSUL teve $9 \%$ e, na USP, nenhum dos pesquisados declarou pertencer a esse grupo.

Etnia (classificação usada pelo IBGE):

\begin{tabular}{|l|r|r|}
\hline & UNICSUL & \multicolumn{1}{|c|}{ USP } \\
\hline Amarela & 3 & 1 \\
\hline Branca & 28 & 32 \\
\hline Parda & 8 & 5 \\
\hline Preta & 4 & 0 \\
\hline Sem resposta & 2 & 3 \\
\hline Total & 45 & 41 \\
\hline
\end{tabular}

Quanto ao transporte utilizado para ir à universidade, o ônibus foi o meio mais citado pelos estudantes: $61 \%$ na USP e 51\% na UNICSUL. Parte desses percentuais inclui também a combinação com outros meios de transporte, como metrô e trem. $\mathrm{O}$ carro teve presença idêntica tanto na universidade pública quanto na privada: $27 \%$ dos alunos utilizam esse meio de transporte. As opções "a pé" e "lotação" foram citadas somente na UNICSUL, assim como a opção "trem” foi citada apenas na USP. 
Qual o meio de transporte utilizado para ir à universidade? (Questão aberta)

\begin{tabular}{|l|r|r|}
\hline & UNICSUL & USP \\
\hline A pé & 6 & 0 \\
\hline Carro & 12 & 11 \\
\hline Ônibus & 22 & 14 \\
\hline Ônibus, metrô & 1 & 8 \\
\hline Metrô, trem, ônibus & 0 & 2 \\
\hline Trem, ônibus & 0 & 1 \\
\hline Lotação & 1 & 0 \\
\hline Sem resposta & 3 & 5 \\
\hline Total & 45 & 41 \\
\hline
\end{tabular}

Assim como o percentual de estudantes que utilizam carro foi idêntico nas duas universidades, o percentual daqueles que possuem automóvel também foi o mesmo: 49\%. Porém, como vimos, pouco mais da metade utiliza o carro no deslocamento até a universidade.

Possui carro?

\begin{tabular}{|l|r|r|}
\hline & UNICSUL & USP \\
\hline Sim & 22 & 20 \\
\hline Não & 22 & 20 \\
\hline Sem resposta & 1 & 1 \\
\hline Total & 45 & 41 \\
\hline
\end{tabular}

A questão sobre a renda média mensal familiar teve resultados distintos nas duas universidades, com a universidade pública apresentando uma renda mais elevada. $\mathrm{Na}$ USP, a maior parte dos alunos pesquisados (39\%) disse ter uma renda familiar de cinco a sete salários mínimos. Já na UNICSUL, a parcela mais significativa (40\%) afirmou ter renda de dois a quatro salários mínimos. A diferença fica ainda mais evidente quando comparamos a maior e a menor renda apontadas. O grupo que marcou onze salários mínimos ou mais representa $27 \%$ na USP e $9 \%$ na UNICSUL. Já o grupo que marcou de dois a quatro salários mínimos representa $7 \%$ e 40\%, respectivamente (como vimos, a maioria da universidade privada diz ter essa renda mensal familiar). Na faixa de oito a dez salários mínimos, a representação na USP foi de $17 \%$ e, na UNICSUL, de $11 \%$. 
Renda média mensal familiar*:

\begin{tabular}{|l|r|r|}
\hline & UNICSUL & \multicolumn{1}{|c|}{ USP } \\
\hline Até um salário mínimo & 0 & 0 \\
\hline Dois a quatro salários mínimos & 18 & 3 \\
\hline Cinco a sete salários mínimos & 15 & 16 \\
\hline Oito a dez salários mínimos & 5 & 7 \\
\hline Onze ou mais salários mínimos & 4 & 11 \\
\hline Sem resposta & 3 & 4 \\
\hline Total & 45 & 41 \\
\hline
\end{tabular}

${ }^{*}$ Um salário mínimo equivale a $\mathrm{R} \$ 510,00$ (valor nacional de 2010)

No que se refere a trabalho, a maior parte dos alunos tanto da USP quanto da UNICSUL trabalha, porém recebe ajuda financeira da família. Esse grupo representa 44\% dos pesquisados da USP e 40\% dos pesquisados da UNICSUL. Já em relação aos que não trabalham, a diferença entre as duas universidades é maior: $39 \%$ e 27\%, respectivamente. Bastante diferentes também são os percentuais de quem trabalha e contribui para o sustento da família: na instituição pública, apenas $2 \%$ pertencem a esse grupo; já na privada, são 18\%. Da mesma forma, $9 \%$ dos alunos da UNICSUL são os principais responsáveis pelo sustento familiar, função não exercida por nenhum dos estudantes da outra universidade. Já aqueles que trabalham e são responsáveis apenas pelo próprio sustento representam 10\% na USP e $4 \%$ na UNICSUL.

Em relação ao trabalho, você:

\begin{tabular}{|l|r|r|}
\hline & UNICSUL & USP \\
\hline Não trabalha & 12 & 16 \\
\hline Trabalha e contribui para o sustento da família & 8 & 1 \\
\hline Trabalha e é o principal responsável pelo sustento familiar & 4 & 0 \\
\hline Trabalha e é responsável apenas pelo próprio sustento & 2 & 4 \\
\hline Trabalha, mas recebe ajuda financeira da família & 18 & 18 \\
\hline Sem resposta & 1 & 2 \\
\hline Total & 45 & 41 \\
\hline
\end{tabular}

A ocupação profissional mostrou-se variada, porém com concentração em funções ligadas à educação ou ao curso de graduação, como professor, estagiário e auxiliar de classe.

Ocupação profissional dos alunos da UNICSUL: (Questão aberta)

\begin{tabular}{|l|r|}
\hline Agente de passageiros & 1 \\
\hline Aluna pesquisadora & 3 \\
\hline Assistente administrativo & 1 \\
\hline Auxiliar de classe & 1 \\
\hline
\end{tabular}




\begin{tabular}{|l|r|} 
Comerciante & 2 \\
\hline Estagiário & 8 \\
\hline Monitora de qualidade & 1 \\
\hline Operadora de produção & 1 \\
\hline Professor & 9 \\
\hline Recepcionista & 1 \\
\hline Sacerdote religioso & 1 \\
\hline Selecionadora & 1 \\
\hline Sem resposta & 2 \\
\hline Total & 32 \\
\hline
\end{tabular}

Ocupação profissional dos alunos da USP: (Questão aberta)

\begin{tabular}{|l|r|}
\hline Auxiliar de classe & 6 \\
\hline Estagiário & 4 \\
\hline Jornalista & 1 \\
\hline Monitor & 2 \\
\hline Pedagogo & 1 \\
\hline Professor & 8 \\
\hline Sem resposta & 1 \\
\hline Total & 23 \\
\hline
\end{tabular}

O principal local de trabalho apontado pelos pesquisados foi "escola", porém com uma diferença entre as duas universidades: na UNICSUL, em primeiro lugar aparece escola pública, com 50\%; já na USP, a maior parcela, 57\%, trabalha em escola particular.

Local onde trabalha:

\begin{tabular}{|l|r|r|}
\hline & UNICSUL & \multicolumn{1}{|c|}{ USP } \\
\hline Escola pública & 16 & 4 \\
\hline Escola particular & 3 & 13 \\
\hline Empresa privada & 9 & 3 \\
\hline Instituição pública & 1 & 1 \\
\hline Outro - Em domicílio & 1 & 2 \\
\hline Outro - Igreja evangélica & 1 & 0 \\
\hline Sem resposta & 1 & 0 \\
\hline Total & 32 & 23 \\
\hline
\end{tabular}

Em relação à carga horária, a maior parte dos alunos da UNICSUL (53\%) trabalha de 11 a 20 horas por semana e, na USP, o maior grupo (48\%) tem carga horária semanal de 31 a 40. Somente na UNICSUL, no entanto, uma parcela dos alunos trabalha mais de 40 horas por semana: $22 \%$. 
Carga horária semanal de trabalho*:

\begin{tabular}{|l|r|r|}
\hline & UNICSUL & \multicolumn{1}{|c|}{ USP } \\
\hline 5 a 10 horas & 1 & 3 \\
\hline 11 a 20 horas & 17 & 6 \\
\hline 21 a 30 horas & 3 & 11 \\
\hline 31 a 40 horas & 3 & 1 \\
\hline Mais de 40 horas & 7 & 0 \\
\hline Sem resposta & 1 & 2 \\
\hline Total & 32 & 23 \\
\hline
\end{tabular}

${ }^{*}$ Questão aberta - agrupamento realizado pela pesquisadora

O turno de trabalho condiz com o horário do curso: enquanto a maioria dos alunos da UNICSUL trabalha à tarde, já que os cursos são ministrados no período da manhã, a maior parte dos alunos da USP trabalha de manhã, pois o curso de Pedagogia é vespertino e o de Letras é diurno, podendo variar os horários.

Turno de trabalho:

\begin{tabular}{|l|r|r|}
\hline & UNICSUL & USP \\
\hline Manhã & 0 & 12 \\
\hline Tarde & 20 & 4 \\
\hline Manhã/Tarde & 1 & 2 \\
\hline Tarde/Noite & 7 & 3 \\
\hline Noite & 4 & 2 \\
\hline Total & 32 & 23 \\
\hline
\end{tabular}

\subsection{Hábitos midiáticos e tecnologia}

O questionário aplicado aos alunos dos cursos de Pedagogia e Letras da UNICSUL e da USP também foi utilizado para identificar os hábitos midiáticos desses estudantes. O resultado nos surpreendeu, especialmente em relação à USP. Sabemos que uma técnica de coleta como o questionário, com perguntas fechadas, pode induzir respostas do pesquisado, levando-o a escolher o que chamamos de "socialmente esperado", e não necessariamente o que ele realmente faz em seu dia-a-dia, exigindo um rigor ainda maior na análise dos dados. No entanto, essa expectativa foi rebatida no caso da USP, em que grande parte dos alunos admitiu que não lê jornais (tanto impressos quanto online). Se, por um lado, o resultado nos surpreendeu pela sinceridade dos pesquisados, por outro nos preocupou, pois indica que grande parte dos futuros professores não acompanha os acontecimentos do dia-a-dia. Ficou claro na pesquisa que uma das grandes fontes de informação são as revistas semanais, que trazem os destaques 
da semana já resumidos em seus desdobramentos, prontos para o "consumo". Nem mesmo a televisão é fonte principalmente de notícias, pois, nesse grupo de estudantes, os seriados e filmes aparecem como as programações mais assistidas. A internet, com potencial para ser uma grande fonte de informação diária, é usada principalmente para contatos pessoais e pesquisa/busca por assuntos específicos. Já na UNICSUL, os resultados ficaram mais próximos do que esperávamos, com a maioria esmagadora dos estudantes dizendo que costuma ler jornais. Porém isso não significa necessariamente que eles estejam mais bem informados, pois é possível identificar nos questionários aquela tendência de responder o "socialmente esperado". A pergunta sobre frequência de leitura confirma essa percepção: a minoria lê jornais todos os dias; a maioria lê uma vez por semana ou eventualmente. Apresentamos a seguir os resultados detalhados dessa e de outras questões envolvendo os hábitos midiáticos dos universitários e a familiaridade com a tecnologia.

Do total de 86 pesquisados, $73 \%$ responderam "sim" à pergunta: "Você costuma ler jornais?", e $26 \%$ disseram “não". No entanto, ao dividirmos por universidade, esse número varia bastante, com $39 \%$ dos estudantes da USP admitindo que não leem jornais, contra $13 \%$ da UNICSUL.

Costuma ler jornais?

\begin{tabular}{|l|r|r|r|r|r|r|}
\hline & UNICSUL & USP & $\%$ & Total & $\%$ \\
\hline Não & 6 & $13 \%$ & 16 & $39 \%$ & 22 & $26 \%$ \\
\hline Sim & 38 & $84 \%$ & 25 & $61 \%$ & 63 & $73 \%$ \\
\hline Sem resposta & 1 & $2 \%$ & 0 & $0 \%$ & 1 & $1 \%$ \\
\hline
\end{tabular}

Entre todos os que responderam "sim", fica evidente o desinteresse pelo impresso: $56 \%$ dos alunos disseram que leem eventualmente ou não leem jornal impresso, sendo que apenas $16 \%$ afirmaram fazê-lo diariamente. Já em relação ao online, $41 \%$ disseram acessar diariamente, mas essa versão também não agrada a todos: 40\% leem eventualmente ou não acompanham jornais online.

Com que frequência lê jornal impresso?

\begin{tabular}{|l|r|r|}
\hline & UNICSUL & \multicolumn{1}{|c|}{ USP } \\
\hline Diariamente & 6 & 4 \\
\hline 1 ou 2 vezes por semana & 6 & 2 \\
\hline Aos finais de semana & 2 & 8 \\
\hline Eventualmente & 15 & 7 \\
\hline
\end{tabular}




\begin{tabular}{|l|r|r|} 
Não costumo ler jornal impresso & 9 & 4 \\
\hline Total & 38 & 25 \\
\hline
\end{tabular}

Com que frequência lê jornal online?

\begin{tabular}{|l|r|r|}
\hline & UNICSUL & USP \\
\hline Diariamente & 18 & 8 \\
\hline 1 ou 2 vezes por semana & 7 & 4 \\
\hline Aos finais de semana & 1 & 0 \\
\hline Eventualmente & 7 & 7 \\
\hline Não costumo ler jornal online & 5 & 6 \\
\hline Total & 38 & 25 \\
\hline
\end{tabular}

Ao considerarmos a frequência de leitura em sua totalidade, verificamos que a leitura diária é minoria, pois a maior parte da frequência concentra-se em "uma ou duas vezes por semana", "aos finais de semana" e "eventualmente". Já quando consideramos apenas o jornal online, é possível notar que uma parcela significativa afirma ler diariamente, especialmente no caso da UNICSUL. No entanto, ao cruzarmos esses dados com as informações de acesso à internet (as quais veremos adiante), percebemos mais uma vez que o resultado pode carregar distorções: o acompanhamento de noticiário aparece somente como quarta opção na lista de atividades realizadas por esses estudantes na internet. Houve incoerência nas respostas. Em questões propositalmente colocadas de forma distante no questionário, $73 \%$ dos pesquisados da UNICSUL afirmaram ler jornais online, porém somente $47 \%$ deles disseram ter o hábito de acessar noticiário pela internet. No caso da USP, também houve distorção nesse sentido: $46 \%$ disseram ler jornais online e $22 \%$ afirmaram acessar notícias.

Em relação à leitura de revistas, houve desequilíbrio entre UNICSUL e USP, mas com uma tendência a confirmar esse hábito: 93\% dos estudantes da UNICSUL e 78\% da USP disseram que costumam ler revistas.

Costuma ler revistas?

\begin{tabular}{|l|r|r|r|r|r|r|}
\hline & UNICSUL & \multicolumn{2}{|c|}{ USP } & Total & $\%$ \\
\hline Não & 2 & $4 \%$ & 9 & $22 \%$ & 11 & $13 \%$ \\
\hline Sim & 42 & $93 \%$ & 32 & $78 \%$ & 74 & $86 \%$ \\
\hline Sem resposta & 1 & $2 \%$ & 0 & $0 \%$ & 1 & $1 \%$ \\
\hline
\end{tabular}

A tendência identificada com jornais, de dar preferência ao online, não se repete com revistas: as impressas ainda são as preferidas. Entre os que afirmam ler revistas, 
somente $5 \%$ disseram que não leem revista impressa, enquanto $35 \%$ disseram não ler revista online.

Com que frequência lê revista impressa?

\begin{tabular}{|l|r|r|}
\hline & UNICSUL & USP \\
\hline Diariamente & 2 & 0 \\
\hline 1 ou 2 vezes por semana & 13 & 11 \\
\hline Aos finais de semana & 5 & 5 \\
\hline Eventualmente & 20 & 14 \\
\hline Não costumo ler revista impressa & 2 & 2 \\
\hline Total & 42 & 32 \\
\hline
\end{tabular}

Com que frequência lê revista online?

\begin{tabular}{|l|r|r|}
\hline & UNICSUL & USP \\
\hline Diariamente & 7 & 3 \\
\hline 1 ou 2 vezes por semana & 6 & 3 \\
\hline Aos finais de semana & 5 & 2 \\
\hline Eventualmente & 10 & 8 \\
\hline Não costumo ler revista online & 14 & 16 \\
\hline Total & 42 & 32 \\
\hline
\end{tabular}

Tipo de publicação mais lida (foi pedido para marcar até três opções):

\begin{tabular}{|l|r|r|}
\hline & UNICSUL & USP \\
\hline Semanal & 18 & 21 \\
\hline Feminina & 6 & 5 \\
\hline De entretenimento & 8 & 4 \\
\hline Especializada & 18 & 10 \\
\hline Sem resposta & 1 & 0 \\
\hline
\end{tabular}

A revista semanal é o tipo de publicação mais lida pelos pesquisados, porém não com regularidade semanal: a maioria afirmou ler revistas eventualmente. As revistas especializadas também aparecem com destaque e, ao detalharmos o assunto dessas publicações, um dado da UNICSUL nos chamou a atenção: dez alunos responderam espontaneamente que leem revistas especializadas em "Educação". No questionário, a opção "Especializada" era fechada, porém o complemento era uma questão aberta, ou seja, o pesquisado tinha que escrever o assunto abordado pela revista especializada. Por isso, não esperávamos que houvesse uma grande concentração de tema nas respostas, o que ocorreu na UNICSUL, em que a maioria escreveu "Educação". 
Assuntos das revistas especializadas apontados pelos alunos da UNICSUL:

\begin{tabular}{|l|r|}
\hline Especializada - Decoração & 1 \\
\hline Especializada - Educação & 10 \\
\hline Especializada - Ensino de idiomas & 1 \\
\hline Especializada - Inglês & 1 \\
\hline Especializada - Língua Portuguesa & 1 \\
\hline Especializada - Negócios & 1 \\
\hline Especializada - Nova Escola & 1 \\
\hline Especializada - Saúde & 1 \\
\hline Especializada - Sem especificação & 1 \\
\hline Total & 18 \\
\hline
\end{tabular}

Obviamente, como os cursos pesquisados na UNICSUL são de licenciatura plena, é natural que exista um interesse por leituras relacionadas à Educação, no entanto, devemos ser cautelosos ao considerar esse número porque, ao compararmos com as respostas dos alunos da USP, vemos que ninguém escreveu "Educação", mesmo no curso de Pedagogia, também licenciatura plena:

Assuntos das revistas especializadas apontados pelos alunos da USP:

\begin{tabular}{|l|r|}
\hline Especializada - Literatura & 1 \\
\hline Especializada - Científica & 1 \\
\hline Especializada - Cinema & 1 \\
\hline Especializada - Comércio exterior & 1 \\
\hline Especializada - Cultura & 1 \\
\hline Especializada - Decoração & 1 \\
\hline Especializada - História & 1 \\
\hline Especializada - Sociais & 1 \\
\hline Especializada - Bem-estar & 1 \\
\hline Especializada - História da arte & 1 \\
\hline Total & 10 \\
\hline
\end{tabular}

Nos questionários da USP, nenhum assunto se repetiu. Atribuímos essa diferença nas respostas à união de dois fatores: uma maior disposição dos alunos da UNICSUL a de fato lerem publicações relacionadas à Educação (já que, na USP, esse tema sequer apareceu nas respostas), aliada a uma tendência dos estudantes da UNICSUL de responderem o "socialmente esperado", como citamos no início dessa análise, acarretada pelo próprio ambiente em que o questionário foi aplicado: a sala de aula. Enquanto os alunos da USP tiveram a liberdade de levar o questionário para casa e responder depois, os estudantes da UNICSUL, tanto de Letras quanto de Pedagogia, participaram dessa etapa da pesquisa dentro da sala, durante a aula, a qual foi gentilmente interrompida pelo professor para que os alunos respondessem. Se, por um 
lado, essa receptividade da universidade muito nos ajudou no trabalho de campo, agilizando a coleta de dados, por outro acabou criando um ambiente de certa forma repressor aos pesquisados. Assim como, por exemplo, uma câmera de vídeo pode inibir uma entrevista, a presença do professor e da própria pesquisadora (alguém externo àquele ambiente) durante a aplicação do questionário pode ter contribuído para uma postura defensiva dos alunos, preocupados com a imagem que deveriam passar. No entanto, acreditamos que esse tipo de desvio é esperado numa técnica como o questionário e não compromete o resultado final da pesquisa, pois esta envolve uma combinação de métodos de coleta de dados, exatamente para que um possa complementar o outro, iluminando partes obscuras, como já destacou Lopes.

Outro meio pesquisado em relação a hábito de consumo foi a televisão. A pesquisa identificou que esse meio de comunicação tem um forte apelo junto aos estudantes: $57 \%$ deles assistem à televisão todos os dias. Ao observarmos esse dado em cada universidade, verificamos que, entre os alunos que responderam à questão, $51 \%$ da USP e $62 \%$ da UNICSUL têm o hábito de ver TV diariamente.

Com que frequência assiste à televisão?

\begin{tabular}{|l|r|r|}
\hline & UNICSUL & \multicolumn{1}{|c|}{ USP } \\
\hline Diariamente & 28 & 21 \\
\hline 1 ou 2 vezes por semana & 3 & 6 \\
\hline Aos finais de semana & 1 & 4 \\
\hline Eventualmente & 7 & 5 \\
\hline Não assiste & 3 & 4 \\
\hline Sem resposta & 3 & 1 \\
\hline Total & 45 & 41 \\
\hline
\end{tabular}

$\mathrm{O}$ acesso à programação difere bastante nas duas universidades: enquanto $62 \%$ dos alunos da USP assistem à televisão fechada, ou seja, canais pagos, apenas $25 \%$ dos estudantes da UNICSUL disseram ver esse tipo de programação. O resultado é reflexo do perfil socioeconômico dos pesquisados: como vimos, os alunos da universidade pública têm uma renda mensal familiar mais elevada, com maiores condições, portanto, de acesso à programação paga. 
Assiste à programação aberta (gratuita) ou fechada (paga)?

\begin{tabular}{|l|r|r|}
\hline & UNICSUL & USP \\
\hline Aberta & 24 & 13 \\
\hline Fechada & 10 & 23 \\
\hline Sem resposta & 6 & 1 \\
\hline Total & 40 & 37 \\
\hline
\end{tabular}

A preferência de programação confirma a diferença de acesso à TV aberta e fechada: o programa mais assistido entre os estudantes da USP são os seriados, característicos da TV fechada. Na UNICSUL, esse tipo de programa aparece somente na quinta posição.

Tipo de programa mais assistido (foi pedido para marcar até três opções):

\begin{tabular}{|l|r|}
\hline USP & \\
\hline Seriados & 20 \\
\hline Filmes & 19 \\
\hline Noticiário & 13 \\
\hline Programas de variedades & 8 \\
\hline Telenovela & 5 \\
\hline Programas de humor & 3 \\
\hline Outro - Documentários & 2 \\
\hline Outro - Desenhos & 2 \\
\hline Outro - Shows & 1 \\
\hline Total & 73 \\
\hline
\end{tabular}

\begin{tabular}{|l|r|}
\hline UNICSUL \\
\hline Noticiário & 34 \\
\hline Filmes & 13 \\
\hline Telenovela & 12 \\
\hline Programas de variedades & 9 \\
\hline Seriados & 6 \\
\hline Programas de humor & 4 \\
\hline Outro - Documentários & 2 \\
\hline Outro - Programas de entrevistas & 1 \\
\hline Total & 81 \\
\hline
\end{tabular}

O noticiário aparece em primeiro lugar na lista de programas mais assistidos pelos estudantes da UNICSUL e somente na terceira posição na USP. Mesmo esses alunos tendo acesso à TV paga, com uma vasta cobertura noticiosa, o noticiário representa apenas $18 \%$ do total na USP. Como a pergunta sobre o tipo de programa permitia mais de uma resposta, devemos considerar o número de pessoas que marcou "Noticiário" 
(13) em relação ao número total de pesquisados da USP (41), e assim verificamos que $32 \%$ afirmam assistir ao noticiário. Ao confrontarmos esse dado com a informação de leitura de jornais, analisada anteriormente, verificamos que uma parcela desses estudantes não acompanha os acontecimentos do dia-a-dia, pois 39\% disseram não ler jornais (tanto impresso quanto online). Mesmo se considerássemos que todos os alunos que não leem jornais assistem ao noticiário, ainda restariam $7 \%$ de estudantes que não recorrem a fontes diárias de informação noticiosa.

Assim como houve desigualdade de acesso à TV fechada, a frequência ao cinema também reflete a diferença de perfil socioeconômico dos grupos pesquisados. Na USP, cuja renda média mensal é mais elevada, a frequência ao cinema se concentrou em uma vez por mês $(56 \%)$; já na UNICSUL, a resposta que mais apareceu foi "raramente" (também com 56\%).

Com que frequência vai ao cinema?

\begin{tabular}{|l|r|r|}
\hline & UNICSUL & \multicolumn{1}{|c|}{ USP } \\
\hline Uma vez por semana & 1 & 5 \\
\hline Uma vez por mês & 17 & 23 \\
\hline Raramente & 25 & 12 \\
\hline Não costumo ir ao cinema & 2 & 1 \\
\hline Total & 45 & 41 \\
\hline
\end{tabular}

Apenas $2 \%$ dos alunos da UNICSUL e $12 \%$ dos da USP frequentam o cinema uma vez por semana, mas, quando a pergunta se refere a DVDs, os números mudam bastante: $42 \%$ da UNICSUL e $36 \%$ da USP afirmam assistir uma vez por semana. O resultado indica que o DVD é uma alternativa ao alto custo do cinema, ainda mais numa cidade como São Paulo, em que o ingresso nas grandes redes custa cerca de R $\$ 20$ por pessoa, fora as despesas com transporte, estacionamento e alimentação.

Com que frequência assiste a DVDs?

\begin{tabular}{|l|r|r|}
\hline & UNICSUL & USP \\
\hline Uma vez por semana & 19 & 15 \\
\hline Uma vez por mês & 13 & 15 \\
\hline Raramente & 12 & 9 \\
\hline Não costumo assistir a DVDs & 0 & 1 \\
\hline Sem resposta & 1 & 1 \\
\hline Total & 45 & 41 \\
\hline
\end{tabular}


Entre os gêneros de cinema preferidos, o campeão na UNICSUL é romance, com $21 \%$ das respostas, seguido por comédia e documentário. Na USP, o gênero preferido é drama, com $22 \%$ das respostas, seguido por comédia e romance.

Gênero de cinema preferido (foi pedido para marcar até três opções):

\begin{tabular}{|l|r|r|}
\hline & \multicolumn{1}{|c|}{ UNICSUL } & \multicolumn{1}{|c|}{ USP } \\
\hline Ação & 2 & 0 \\
\hline Aventura & 9 & 8 \\
\hline Comédia & 21 & 16 \\
\hline Documentário & 17 & 9 \\
\hline Drama & 10 & 19 \\
\hline Ficção científica & 6 & 8 \\
\hline Romance & 22 & 14 \\
\hline Suspense & 11 & 8 \\
\hline Terror & 4 & 1 \\
\hline Outro - Desenho & 1 & 0 \\
\hline Outro - Musical & 0 & 1 \\
\hline Outro - Sem especificação & 0 & 1 \\
\hline Sem resposta & 2 & 1 \\
\hline Total & 105 & 86 \\
\hline
\end{tabular}

Quando entramos nas questões referentes à tecnologia, percebemos o quanto o computador e a internet fazem parte da rotina dos estudantes, tanto da USP quanto da UNICSUL, inclusive com igualdade de acesso aos recursos. Quase 100\% dos alunos possuem computador em casa, e com acesso à internet banda larga. Achamos importante destacar essa questão porque sabemos que há uma grande diferença entre acessar internet discada e internet banda larga. Mesmo acessos mais limitados de banda larga permitem navegar de maneira superior ao acesso discado, possibilitando usufruir de todos os recursos oferecidos na web.

Entre os alunos que participaram da pesquisa de campo, 100\% da USP e $96 \%$ da UNICSUL possuem computador em casa:

Tem computador em casa?

\begin{tabular}{|l|r|r|}
\hline & UNICSUL & \multicolumn{1}{|c|}{ USP } \\
\hline Sim & 43 & 41 \\
\hline Não & 2 & 0 \\
\hline Total & 45 & 41 \\
\hline
\end{tabular}


Entre os que têm computador, todos acessam a internet de casa, tanto na UNICSUL quanto na USP:

Tem acesso à internet em casa?

\begin{tabular}{|l|r|r|}
\hline & UNICSUL & USP \\
\hline Sim & 43 & 41 \\
\hline Não & 0 & 0 \\
\hline Total & 43 & 41 \\
\hline
\end{tabular}

Nas duas universidades, a grande maioria dos estudantes pesquisados tem acesso à internet banda larga: 84\% na UNICSUL e 93\% na USP:

Tipo de conexão à internet:

\begin{tabular}{|l|r|r|}
\hline & UNICSUL & \multicolumn{1}{|c|}{ USP } \\
\hline Banda larga & 36 & 38 \\
\hline Discada & 6 & 2 \\
\hline Sem resposta & 1 & 1 \\
\hline Total & 43 & 41 \\
\hline
\end{tabular}

Consequentemente, o local de onde os estudantes mais acessam a internet é a casa também: 91\% na UNICSUL e 93\% na USP.

Local de onde mais acessa a internet:

\begin{tabular}{|l|r|r|}
\hline & UNICSUL & USP \\
\hline Casa & 41 & 38 \\
\hline Lan house & 1 & 0 \\
\hline Trabalho & 1 & 3 \\
\hline Universidade & 1 & 0 \\
\hline Sem resposta & 1 & 0 \\
\hline Total & 45 & 41 \\
\hline
\end{tabular}

Quando o questionário solicitou que fossem marcadas até três atividades que o estudante mais realiza na internet, o resultado novamente foi parecido nas duas universidades: "pesquisa" e "contato com outras pessoas" são as duas principais atividades. Em terceiro lugar, aparece "busca". A partir daí, o resultado varia um pouco: na UNICSUL, a quarta, a quinta e a sexta posições são ocupadas, respectivamente, por “acompanhamento de noticiário", “compras" e "diversão". Na USP, “diversão" aparece 
na quarta posição, e, na quinta, "acompanhamento de noticiário". A opção "compras" não foi marcada por nenhum pesquisado da USP.

Atividades que mais realiza na internet (foi pedido para marcar até três opções):

\begin{tabular}{|l|r|r|}
\hline & UNICSUL & \multicolumn{1}{|c|}{ USP } \\
\hline Pesquisa & 42 & 36 \\
\hline Contato com outras pessoas & 32 & 34 \\
\hline Busca & 21 & 22 \\
\hline Acompanhamento de noticiário & 21 & 9 \\
\hline Compras & 6 & 0 \\
\hline Diversão - jogos, vídeos etc & 1 & 12 \\
\hline Sem resposta & 0 & 1 \\
\hline Total & 123 & 114 \\
\hline
\end{tabular}

Entre as atividades realizadas na internet, a opção "acompanhamento de noticiário" foi escolhida por $47 \%$ dos pesquisados da UNICSUL e $22 \%$ dos pesquisados da USP, sinalizando a incoerência a que nos referimos anteriormente, ao analisar a leitura de jornais online. Embora $73 \%$ dos pesquisados da UNICSUL tenham afirmado, numa das primeiras questões, ler jornais online, posteriormente somente $47 \%$ disseram acompanhar notícias pela internet. Na USP, também houve diferença: $46 \%$ disseram ler jornais online, enquanto $22 \%$ afirmaram acessar notícias. O confronto das questões evidencia a distorção: se os alunos que afirmaram ler jornais online tivessem de fato esse hábito, o acompanhamento de noticiário pela internet deveria apresentar uma porcentagem parecida, o que não ocorreu. Na primeira questão, voltada exclusivamente para a leitura de jornais, houve uma tendência em responder o que seria "socialmente esperado", isto é, um universitário "deve" ler jornais. Já na questão posterior, sobre atividades realizadas na internet, não havia essa preocupação específica, o que acabou revelando a incoerência nas respostas.

A pergunta seguinte, sobre o tipo de site mais visitado, reafirma essa incoerência, pois somente $44 \%$ dos pesquisados da UNICSUL e $37 \%$ da USP apontaram "Notícias do dia" como um tipo de site que costumam visitar, em contraposição aos $73 \%$ e 46\%, respectivamente, que afirmaram ler jornais online.

Tipo de site que mais costuma visitar (foi pedido para marcar até três opções):

\begin{tabular}{|l|r|r|}
\hline & UNICSUL & USP \\
\hline E-mail & 39 & 40 \\
\hline Buscadores & 18 & 22 \\
\hline Conteúdo educacional & 25 & 8 \\
\hline
\end{tabular}




\begin{tabular}{|l|r|r|} 
Notícias do dia & 20 & 15 \\
\hline De relacionamento & 15 & 16 \\
\hline Conteúdo de entretenimento & 3 & 11 \\
\hline Conteúdo especializado* & 3 & 4 \\
\hline Vendas & 2 & 1 \\
\hline Bate-papo & 3 & 0 \\
\hline Conteúdo esportivo & 1 & 0 \\
\hline Sem resposta & 1 & 0 \\
\hline Total & 130 & 117 \\
\hline
\end{tabular}

*Quatro pessoas especificaram a que se refere o conteúdo especializado:

Inglês (UNICSUL), e Música, Cultura e Artes (USP)

O e-mail representa o principal acesso dos estudantes na web, tanto da USP quanto da UNICSUL. A outra parcela significativa de acesso divide-se entre busca/pesquisa, conteúdo noticioso/educacional e sites de relacionamento. Vale salientar que a opção "conteúdo educacional" ocupando a segunda posição da lista de sites mais visitados pelos alunos da UNICSUL remete ao possível desvio já identificado anteriormente com as revistas especializadas.

Diante dos dois últimos quadros, podemos concluir que a internet é usada principalmente para comunicação e pesquisa, e o principal meio de comunicação é o email, superando inclusive o celular, como mostram os números a seguir.

Tem e-mail?

\begin{tabular}{|l|r|r|}
\hline & UNICSUL & \multicolumn{1}{|c|}{ USP } \\
\hline Sim & 45 & 41 \\
\hline Não & 0 & 0 \\
\hline Total & 45 & 41 \\
\hline
\end{tabular}

Todos os 86 estudantes pesquisados têm e-mail, e a grande maioria costuma acessar as mensagens todos os dias: $95 \%$ na USP e $80 \%$ na UNICSUL:

Com que frequência acessa o e-mail?

\begin{tabular}{|l|r|r|}
\hline & UNICSUL & USP \\
\hline Diariamente & 36 & 39 \\
\hline 1 ou 2 vezes por semana & 8 & 2 \\
\hline Aos finais de semana & 1 & 0 \\
\hline Total & 45 & 41 \\
\hline
\end{tabular}

A maioria dos estudantes das duas universidades possui e usa com frequência mais de uma conta de e-mail: 
Quantas contas de e-mail possui?

\begin{tabular}{|l|r|r|}
\hline & UNICSUL & USP \\
\hline Uma conta & 18 & 6 \\
\hline Duas contas & 14 & 9 \\
\hline Três contas & 10 & 17 \\
\hline Quatro contas ou mais & 2 & 9 \\
\hline Sem resposta & 1 & 0 \\
\hline Total & 45 & 41 \\
\hline
\end{tabular}

Se possui mais de um e-mail, quantos acessa ao menos uma vez por semana?

\begin{tabular}{|l|r|r|}
\hline & \multicolumn{1}{|c|}{ UNICSUL } & \multicolumn{1}{c|}{ USP } \\
\hline Um e-mail & 8 & 6 \\
\hline Dois e-mails & 14 & 15 \\
\hline Três e-mails & 3 & 14 \\
\hline Quatro e-mails ou mais & 1 & 0 \\
\hline Total & 26 & 35 \\
\hline
\end{tabular}

Na UNICSUL, 40\% dos estudantes pesquisados possuem uma única conta de email e $58 \%$ possuem ao menos duas contas. Na USP, esses mesmos grupos representam $15 \%$ e $85 \%$, respectivamente. Entre os que possuem mais de um e-mail, a maior parte acessa duas contas ao menos uma vez por semana tanto na UNICSUL quanto na USP. O fato de possuir e acessar mais de uma conta de e-mail pode indicar categorização, ou seja, utilização do e-mail de acordo com o público (um para os amigos, outro para o trabalho, por exemplo), e sinaliza a disposição do futuro professor em conhecer diferentes plataformas, visto que os serviços de e-mail, embora tenham uma funcionalidade comum, apresentam variações na forma de apresentação e particularidades de recursos.

O comunicador instantâneo, por sua vez, não apresenta o mesmo alcance que o email junto aos alunos, mas ainda assim tem uma presença expressiva: $77 \%$ dos pesquisados utilizam comunicadores como MSN, da Microsoft, e G-talk, do Google.

Usa comunicador instantâneo?

\begin{tabular}{|l|r|r|}
\hline & \multicolumn{1}{|c|}{ UNICSUL } & \multicolumn{1}{c|}{ USP } \\
\hline Sim & 36 & 30 \\
\hline Não & 9 & 11 \\
\hline Total & 45 & 41 \\
\hline
\end{tabular}


Na UNICSUL, 80\% dos alunos que participaram da pesquisa usam comunicador instantâneo. Na USP, essa proporção é de 73\%. Em relação à frequência de utilização, os estudantes da universidade privada também mostram que utilizam mais essa ferramenta: $47 \%$ conversam todos os dias por meio de comunicadores instantâneos, contra $40 \%$ da universidade pública.

Com que frequência usa comunicador instantâneo?

\begin{tabular}{|l|r|r|}
\hline & UNICSUL & \multicolumn{1}{|c|}{ USP } \\
\hline Diariamente & 17 & 12 \\
\hline 1 ou 2 vezes por semana & 9 & 8 \\
\hline Aos finais de semana & 3 & 2 \\
\hline Eventualmente & 7 & 8 \\
\hline Total & 36 & 30 \\
\hline
\end{tabular}

O e-mail mostra-se o principal meio de comunicação dos pesquisados inclusive quando comparado ao celular, pois, enquanto $100 \%$ deles usam e-mail, o uso de celular fica em $98 \%$ tanto na USP quanto na UNICSUL.

Tem celular?

\begin{tabular}{|c|c|c|}
\hline & UNICSUL & USP \\
\hline Sim & 44 & 40 \\
\hline Não & 1 & 1 \\
\hline Total & 45 & 41 \\
\hline
\end{tabular}

O envio de mensagens de texto pelo celular (SMS) é um hábito para 98\% dos alunos da USP e para 77\% dos estudantes da UNICSUL. Já o acesso à internet pelo celular está bem distante da realidade dos dois públicos: $98 \%$ dos alunos de ambas as universidades não navegam pelo celular. Os quadros abaixo mostram os números:

Costuma enviar mensagens de texto pelo celular?

\begin{tabular}{|l|r|r|}
\hline & \multicolumn{1}{|c|}{ UNICSUL } & \multicolumn{1}{c|}{ USP } \\
\hline Sim & 34 & 39 \\
\hline Não & 10 & 1 \\
\hline Total & 44 & 40 \\
\hline
\end{tabular}


Acessa a internet pelo celular?

\begin{tabular}{|l|r|r|}
\hline & \multicolumn{1}{|c|}{ UNICSUL } & \multicolumn{1}{c|}{ USP } \\
\hline Sim & 1 & 1 \\
\hline Não & 43 & 39 \\
\hline Total & 44 & 40 \\
\hline
\end{tabular}

Na pergunta sobre qual seria a outra principal utilização do celular além de fazer e receber chamadas e mensagens, a resposta foi parecida nas duas universidades: os estudantes usam o aparelho como despertador. Em segundo lugar, aparece agenda e, em terceiro, câmera fotográfica.

Qual outra principal função do celular? (Foi permitido marcar mais de uma opção)

\begin{tabular}{|l|r|r|}
\hline & UNICSUL & \multicolumn{1}{|c|}{ USP } \\
\hline Despertador & 35 & 33 \\
\hline Agenda & 20 & 16 \\
\hline Câmera fotográfica & 15 & 11 \\
\hline Gravação de vídeo & 4 & 1 \\
\hline Outro - Rádio & 1 & 4 \\
\hline Acesso à web & 0 & 1 \\
\hline GPS & 1 & 0 \\
\hline Nenhum & 1 & 0 \\
\hline Total & 77 & 66 \\
\hline
\end{tabular}

Apesar de estarem em pleno contato com o computador e a internet, os estudantes não detêm um conhecimento mais aprofundado da informática. As perguntas sobre o grau de domínio e a frequência de uso de três programas de computador sinalizam que existe uma brecha entre o conhecimento intuitivo, aquele adquirido no dia a dia com a navegação pela internet, e o conhecimento específico das ferramentas que poderiam ajudar a tirar maior proveito dos recursos tecnológicos. Elegemos três programas que consideramos importantes para o uso do computador, todos do chamado "pacote Office", da Microsoft, os quais costumam vir instalados de fábrica nos computadores com sistema operacional Windows. São eles: Word (editor de texto), Excel (editor de planilhas, gráficos e cálculos) e Power Point (editor de slides).

O Word foi o programa que apresentou maior grau de domínio entre os estudantes, o que já era esperado, pois esse é o programa mais comum, especialmente em ambiente universitário, já que é voltado para produções textuais. No entanto, mesmo em relação ao Word, o percentual dos que declararam ter um conhecimento superficial do programa 
foi alto entre os estudantes da Unicusl: $40 \%$ disseram conhecer somente o básico. Na sequência, $33 \%$ declararam ter um domínio avançado, 24\% intermediário e 2\% afirmaram não ter nenhum conhecimento sobre o programa. Na USP, os números foram bem diferentes: $49 \%$ disseram ter conhecimento avançado do Word, $41 \%$ intermediário e somente $10 \%$ básico.

Domínio do Word:

\begin{tabular}{|l|r|r|}
\hline & \multicolumn{1}{|c|}{ UNICSUL } & \multicolumn{1}{c|}{ USP } \\
\hline Básico & 18 & 4 \\
\hline Intermediário & 11 & 17 \\
\hline Avançado & 15 & 20 \\
\hline Nenhum & 1 & 0 \\
\hline
\end{tabular}

Em relação à frequência de uso, os números mostram que um conhecimento mais específico de programas informáticos não está necessariamente atrelado à utilização, pois, apesar de 40\% dos alunos da UNICSUL terem declarado que possuem um conhecimento básico do Word, $45 \%$ deles afirmam fazer uso do programa diariamente. Da mesma forma, na USP, em que 49\% declararam ter um domínio avançado, a maior parte não utiliza com frequência diária: $34 \%$ dizem usar o programa uma ou duas vezes por semana.

Frequência de uso do Word:

\begin{tabular}{|l|r|r|}
\hline & UNICSUL & \multicolumn{1}{|c|}{ USP } \\
\hline Diário & 20 & 13 \\
\hline 1 ou 2 vezes por semana & 10 & 14 \\
\hline Quinzenal & 2 & 3 \\
\hline Eventual & 1 & 7 \\
\hline Sem resposta & 11 & 4 \\
\hline
\end{tabular}

Quando a sondagem se refere ao Excel, os resultados de USP e UNICSUL se aproximam e, desta vez, o conhecimento mais específico pende para a UNICSUL: 7\% dos estudantes dessa universidade afirmam ter domínio avançado do Excel, contra $2 \%$ da USP. Além disso, 20\% dos estudantes da universidade pública dizem não ter nenhum conhecimento do programa, contra $2 \%$ da particular. Os que declararam ter domínio básico somam 56\% na USP e 64\% na UNICSUL. O percentual do nível intermediário é idêntico nas duas universidades: $22 \%$. 
Domínio do Excel:

\begin{tabular}{|l|r|r|}
\hline & \multicolumn{1}{|c|}{ UNICSUL } & \multicolumn{1}{|c|}{ USP } \\
\hline Básico & 29 & 23 \\
\hline Intermediário & 10 & 9 \\
\hline Avançado & 3 & 1 \\
\hline Nenhum & 1 & 8 \\
\hline Sem resposta & 2 & 0 \\
\hline
\end{tabular}

Entre os que declararam possuir algum grau de domínio do Excel, a grande maioria diz usar somente eventualmente o programa ou preferiu não marcar nenhuma das opções, indicando que não usa:

Frequência de uso do Excel:

\begin{tabular}{|l|r|r|}
\hline & \multicolumn{1}{|c|}{ UNICSUL } & \multicolumn{1}{|c|}{ USP } \\
\hline Diário & 5 & 0 \\
\hline 1 ou 2 vezes por semana & 5 & 2 \\
\hline Quinzenal & 1 & 2 \\
\hline Eventual & 20 & 23 \\
\hline Sem resposta & 11 & 6 \\
\hline
\end{tabular}

O domínio do Power Point, na UNICSUL, seguiu a mesma tendência dos outros programas: os alunos declararam ter um domínio básico do software (51\%). Já na USP, houve predomínio do conhecimento intermediário, com 44\%. A frequência de utilização foi declarada "eventual" pela maior parte dos alunos nas duas universidades.

Domínio do Power Point:

\begin{tabular}{|l|r|r|}
\hline & UNICSUL & \multicolumn{1}{|c|}{ USP } \\
\hline Básico & 23 & 11 \\
\hline Intermediário & 8 & 18 \\
\hline Avançado & 8 & 11 \\
\hline Nenhum & 3 & 1 \\
\hline Sem resposta & 3 & 0 \\
\hline
\end{tabular}

Frequência de uso do Power Point:

\begin{tabular}{|l|r|r|}
\hline & \multicolumn{1}{|c|}{ UNICSUL } & \multicolumn{1}{|c|}{ USP } \\
\hline Diário & 2 & 1 \\
\hline 1 ou 2 vezes por semana & 2 & 5 \\
\hline Quinzenal & 8 & 4 \\
\hline Eventual & 23 & 25 \\
\hline Sem resposta & 4 & 5 \\
\hline
\end{tabular}


O questionário trazia ainda uma questão aberta para que o aluno pudesse informar outro programa de computador com o qual tivesse familiaridade. No total, dez pessoas preencheram a opção, o que representa $12 \%$ do número de pesquisados. O editor de imagens Photoshop e o banco de dados Access foram os mais citados, além de Corel Draw e OneNote. Houve também quem citasse internet e jogo online ("FastAir") como programas de computador.

Outro programa de computador que conhece:

\begin{tabular}{|l|r|r|}
\hline & \multicolumn{1}{|c|}{ UNICSUL } & \multicolumn{1}{c|}{ USP } \\
\hline Access & 2 & 1 \\
\hline Photoshop & 0 & 3 \\
\hline Corel Draw & 0 & 1 \\
\hline Internet & 1 & 0 \\
\hline OneNote & 1 & 0 \\
\hline FastAir & 1 & 0 \\
\hline Total & 5 & 5 \\
\hline
\end{tabular}

Também procuramos identificar se os futuros professores conhecem programas de computador voltados à educação, e $80 \%$ deles responderam que não.

Conhece programas informáticos voltados à educação?

\begin{tabular}{|l|r|r|}
\hline & UNICSUL & \multicolumn{1}{|c|}{ USP } \\
\hline Sim & 7 & 3 \\
\hline Não & 31 & 38 \\
\hline Sem resposta & 7 & 0 \\
\hline Total & 45 & 41 \\
\hline
\end{tabular}

Quem respondia que sim tinha a opção de informar qual era o programa e se utilizava o recurso em sala de aula, caso lecionasse. Na UNICSUL, entre os que responderam à questão aberta, sobre o programa que conhecem, foi possível notar que algumas pessoas confundem programas informáticos voltados à educação com programas de TV educativos. Houve ainda quem citasse os sites do MEC e do INEP como exemplos, bem como os CEUs de São Paulo (Centros Educacionais Unificados). Mas também encontramos exemplos mais próximos do objetivo da pergunta, embora não específicos, como jogos educativos e dicionários eletrônicos. No caso da USP, as respostas foram mais adequadas à pergunta, trazendo dois exemplos de programas informáticos educativos, Cabri Géometré e LOGO, e um exemplo de site que pode ser 
explorado em sala de aula, o "Porta Curtas", sobre exibição e catalogação de filmes de curta-metragem brasileiros.

Cite qual programa informático voltado à educação você conhece:

\begin{tabular}{|l|r|r|}
\hline & \multicolumn{1}{|c|}{ UNICSUL } & USP \\
\hline Cabri Géometré (desenho geométrico) & & 1 \\
\hline LOGO (linguagem de programação para matemática) & 1 & 1 \\
\hline "Porta curtas" (site de catalogação de filmes) & 2 & \\
\hline Jogos educativos para o Ensino Fundamental & 1 & \\
\hline Dicionários eletrônicos & 1 & \\
\hline "Escola em casa", da TV Cultura & 1 & \\
\hline Globo e TV a cabo & 1 & \\
\hline MEC, INEP & & \\
\hline Centros unificados (CEUs) & & \\
\hline
\end{tabular}

Entre as pessoas que citaram exemplos de programas informáticos voltados à educação e que lecionam, todas disseram não usar esses programas em suas aulas.

Usa esses programas em suas aulas? (Para quem leciona)

\begin{tabular}{|l|r|r|}
\hline & UNICSUL & \multicolumn{1}{|c|}{ USP } \\
\hline Sim & 0 & 0 \\
\hline Não & 4 & 2 \\
\hline
\end{tabular}

\subsection{Formação para a inter-relação comunicação/educação}

Por meio do questionário, também procuramos verificar se o estudante recebeu em algum momento na universidade uma formação que aproximasse a educação da comunicação e sua visão sobre o uso de meios de comunicação em sala de aula. No que se refere a disciplinas voltadas à comunicação, as respostas apresentaram uma homogeneidade tanto no curso de Pedagogia quanto no curso de Letras da USP, e também no curso de Pedagogia da UNICSUL, com a grande maioria dos alunos de cada grupo optando por uma mesma alternativa do questionário. Já o curso de Letras da UNICSUL apresentou um resultado heterogêneo, havendo quase que um equilíbrio entre alternativas opostas. 
Seu curso de graduação oferece alguma disciplina voltada ao estudo da comunicação na educação?

\begin{tabular}{|l|r|r|r|r|}
\hline & \multicolumn{2}{|c|}{ UNICSUL } & \multicolumn{2}{c|}{ USP } \\
\hline & Pedagogia & Letras & Pedagogia & Letras \\
\hline Sim & 13 & 10 & 17 & 1 \\
\hline Não & 3 & 11 & 1 & 19 \\
\hline Sem resposta & 6 & 2 & 1 & 2 \\
\hline Total & 22 & 23 & 19 & 22 \\
\hline
\end{tabular}

O curso de Pedagogia da UNICSUL teve o "sim" como resposta predominante, com 59\%, contra 14\% "não". Já o curso de Letras dessa mesma universidade ficou dividido entre "sim" e "não", com $43 \%$ e $48 \%$, respectivamente. Na USP, os dois cursos apresentaram uma grande homogeneidade nas respostas, porém com resultados opostos. Enquanto Pedagogia teve $89 \%$ de respostas "sim", ou seja, os alunos disseram que receberam uma formação voltada ao estudo da comunicação na educação, Letras teve $86 \%$ de respostas "não".

A questão seguinte corrobora esses resultados, pois foi solicitado aos alunos que informassem o nome da disciplina: mais uma vez, o curso de Pedagogia da USP mostrou uma grande homogeneidade, e o curso de Pedagogia da UNICSUL também seguiu essa tendência. Já o curso de Letras da UNICSUL apresentou uma heterogeneidade mesmo entre aqueles alunos que responderam "sim" anteriormente, indicando uma maior dificuldade em identificar uma disciplina voltada à comunicação.

Apresentamos a seguir os quadros por curso:

Pedagogia/USP - Disciplinas voltadas à comunicação (questão aberta):

\begin{tabular}{|l|r|}
\hline Comunicação, educação e multimídia & 13 \\
\hline Didática & 2 \\
\hline Disciplinas optativas & 1 \\
\hline Metodologia do ensino de arte e movimento corporal & 1 \\
\hline Mídia e educação: um debate contemporâneo & 1 \\
\hline Sem resposta & 1 \\
\hline Total & 19 \\
\hline
\end{tabular}

No curso de Pedagogia da USP, a disciplina "Comunicação, educação e multimídia" foi indicada espontaneamente por $68 \%$ dos alunos que responderam "sim" à pergunta "Seu curso de graduação oferece alguma disciplina voltada ao estudo da comunicação na educação?”. Trata-se de uma disciplina optativa eletiva, cuja proposta veremos adiante, porém facilmente identificável: o próprio nome sinaliza a relação entre 
comunicação e educação, o que certamente contribuiu para a imediata associação à pergunta do questionário e, consequentemente, uma maior homogeneidade nas respostas. Duas pessoas também indicaram "Didática", uma disciplina obrigatória que também trabalha a questão da comunicação, embora de forma implícita. Houve ainda a indicação de outras duas disciplinas optativas, "Metodologia do ensino de arte e movimento corporal" e "Mídia e educação: um debate contemporâneo", a qual também faz alusão à relação comunicação/educação no próprio nome, porém não teve o mesmo quórum que "Comunicação, educação e multimídia". Uma pessoa também respondeu apenas "disciplinas optativas", sugerindo que a abordagem comunicação/educação ocorre de forma externa à grade regular do curso.

Letras/USP - Disciplinas voltadas à comunicação (questão aberta):

\begin{tabular}{|l|r|}
\hline Sem resposta & 1 \\
\hline Total & 1 \\
\hline
\end{tabular}

No curso de Letras da USP, apenas uma pessoa respondeu que "sim" à pergunta "Seu curso de graduação oferece alguma disciplina voltada ao estudo da comunicação na educação?", porém ela não informou no questionário qual seria essa disciplina.

Pedagogia/UNICSUL - Disciplinas voltadas à comunicação (questão aberta):

\begin{tabular}{|l|r|}
\hline Tecnologias da informação e da comunicação & 9 \\
\hline Tecnologia da educação & 2 \\
\hline "A maioria estimula a comunicação" & 1 \\
\hline Sem resposta & 1 \\
\hline Total & 13 \\
\hline
\end{tabular}

Assim como ocorreu no curso de Pedagogia da USP, o curso de Pedagogia da UNICSUL teve uma grande homogeneidade na questão aberta: $69 \%$ dos alunos que haviam marcado "sim" anteriormente indicaram espontaneamente a disciplina "Tecnologias da informação e comunicação", que pertence à grade optativa do curso. O fato de trazer o termo "comunicação" no próprio nome da disciplina certamente contribuiu para ela ser lembrada pelos alunos. Duas pessoas indicaram "Tecnologia da educação", mas provavelmente se referiam à mesma disciplina que a maioria dos colegas, pois essa não consta do currículo do curso. Um pesquisado não indicou uma disciplina específica, pois fez questão de ressaltar que a formação como um todo na universidade estimula a comunicação. 
Letras/UNICSUL - Disciplinas voltadas à comunicação (questão aberta):

\begin{tabular}{|l|r|}
\hline Libras & 5 \\
\hline Metodologia da Língua Inglesa & 5 \\
\hline Metodologia da Língua Portuguesa & 5 \\
\hline Linguagem e tecnologia & 3 \\
\hline Linguagem e comunicação & 1 \\
\hline Linguagem e cultura & 1 \\
\hline Total $^{*}$ & 20 \\
\hline
\end{tabular}

*Alguns alunos anotaram mais de uma disciplina

O curso de Letras da UNICSUL foi o que apresentou respostas mais variadas na questão aberta sobre disciplinas voltadas à comunicação. As disciplinas Libras (formalmente chamada de Língua Brasileira de Sinais), Metodologia da Língua Inglesa e Metodologia da Língua Portuguesa representam 20\% cada em relação ao total de respostas e integram o currículo obrigatório do curso. Duas das outras três disciplinas citadas, Linguagem e tecnologia e Linguagem e cultura, não constam mais da grade curricular de Letras após reforma implantada em 2010. Já a disciplina Linguagem e comunicação nunca existiu; provavelmente o aluno referia-se a uma das que foram extintas. A maior parte das disciplinas citadas não corresponde ao propósito da questão, pois perguntamos por aulas voltadas para o estudo da comunicação na educação, e os alunos indicaram disciplinas ligadas a metodologia. A que mais poderia se aproximar de nosso objetivo seria Linguagem e Tecnologia, citada por três alunos, porém ela não faz mais parte do currículo de Letras.

Também foi perguntado aos alunos se eles já realizaram algum curso extracurricular visando ao trabalho com os meios de comunicação na escola, e a grande maioria respondeu que não. Apenas três pessoas responderam "sim" (uma da USP e duas da UNICSUL).

Já realizou curso extracurricular visando ao trabalho com os meios de comunicação na escola?

\begin{tabular}{|l|r|r|}
\hline & UNICSUL & \multicolumn{1}{|c|}{ USP } \\
\hline Sim & 1 & 2 \\
\hline Não & 40 & 36 \\
\hline Sem resposta & 0 & 7 \\
\hline Total & 41 & 45 \\
\hline
\end{tabular}


Qual curso e em qual instituição? (Questão aberta)

\begin{tabular}{|l|r|r|}
\hline & UNICSUL & \multicolumn{1}{|c|}{ USP } \\
\hline Kikubari - Universidade de Buenos Aires & & 1 \\
\hline O texto é o centro - UNICSUL & 1 & \\
\hline Básico - Centro unificado & 1 & \\
\hline
\end{tabular}

A descrição do curso extracurricular realizado, feita por meio de questão aberta, não permitiu identificar uma ligação específica do conteúdo do curso com os meios de comunicação. Um dos cursos citados, Kikubari, refere-se a um ensinamento japonês de atenção e presteza; outro trabalha a questão da centralidade do texto, e a terceira resposta não traz qualquer direcionamento, pois informa apenas o termo "básico".

A contribuição dos meios de comunicação na escola também foi tema do questionário aplicado, e $91 \%$ do total de pesquisados acreditam que os meios podem contribuir com o trabalho do professor.

Meios de comunicação podem contribuir com o trabalho do professor?

\begin{tabular}{|l|r|r|}
\hline & UNICSUL & USP \\
\hline Sim & 39 & 39 \\
\hline Não & 1 & 0 \\
\hline Sem resposta & 5 & 2 \\
\hline Total & 45 & 41 \\
\hline
\end{tabular}

Ao mesmo tempo em que a maioria dos futuros professores acredita na importância dos meios de comunicação para suas aulas, a maioria (86\%) também sente necessidade de uma formação para trabalhar esse tema:

Gostaria de receber formação para trabalhar com os meios de comunicação em sala de aula?

\begin{tabular}{|l|r|r|}
\hline & UNICSUL & USP \\
\hline Sim & 37 & 37 \\
\hline Não & 7 & 1 \\
\hline Sem resposta & 1 & 3 \\
\hline Total & 45 & 41 \\
\hline
\end{tabular}


Nessa questão, havia ainda um campo aberto para que pudessem ser anotadas sugestões. Apenas oito pessoas preencheram, cinco da USP e três da UNICSUL, e somente um tema se repetiu: educação a distância.

Caso tenha alguma sugestão, favor indicar: (Questão aberta)

\begin{tabular}{|l|r|r|}
\hline & UNICSUL & \multicolumn{1}{|c|}{ USP } \\
\hline Educação a distância & 1 & 1 \\
\hline Lousa interativa & 1 & \\
\hline Rádio & 1 & \\
\hline Como usar Power Point e internet de forma criativa & & 1 \\
\hline Produção de conteúdo nos meios de comunicação & & 1 \\
\hline Discussões éticas sobre os meios & & 1 \\
\hline Pedagogia deveria ter disciplina obrigatória sobre os meios & 3 & 1 \\
\hline Total & \\
\hline
\end{tabular}

A maior parte das sugestões envolve o aspecto prático do uso dos meios de comunicação em sala de aula, embora a questão ética também tenha sido levantada por um dos pesquisados. Além disso, um dos comentários refere-se ao curso de Pedagogia da USP como um todo, e não a um ponto específico, pois sugere que a graduação tenha disciplinas obrigatórias que integrem comunicação/educação, e não apenas optativas, cujos horários nem sempre se encaixam no turno regular que o aluno está cursando. Entre as sugestões práticas, a questão das novas tecnologias mostra-se recorrente, com lousa interativa, Power Point, internet e dois pedidos de educação a distância. Uma das pessoas que sugeriram esse tema, aliás, especificou que gostaria de saber como montar e gerenciar cursos a distância, pois sentiu falta desse assunto em sua graduação de Pedagogia na USP ${ }^{13}$. Houve ainda referência direta a um meio tradicional, o rádio, e à produção de conteúdo midiático em geral.

\section{Considerações sobre a análise descritiva}

Embora estejamos trabalhando com pesquisa não-probabilística, cujos resultados não podem ser generalizados, consideramos que nossa amostra na primeira etapa da pesquisa empírica foi significativa e nos permitiu identificar algumas tendências no que se refere à formação e aos hábitos midiáticos dos futuros professores.

Os estudantes de Pedagogia e Letras da USP e da UNICSUL estão “conectados", ou seja, têm computador e acesso à internet, trocam mensagens pelo celular, navegam

\footnotetext{
${ }^{13}$ Verificamos que a grade curricular optativa do curso traz a disciplina "Educação à distância", porém ela não está sendo oferecida aos alunos devido à aposentadoria do docente responsável.
} 
pela web, usam comunicador instantâneo e têm o e-mail como grande meio de comunicação. Porém, ao mesmo tempo em que estão mergulhados nesse universo de interatividade e informação, eles se mantêm distantes do acompanhamento e da reflexão sobre os acontecimentos diários. Não existe o hábito de ler jornais diariamente e, quando há, os futuros professores o fazem em jornais online, cuja característica são informações rápidas, resumidas e fragmentadas, que acompanham o dinamismo da web. Ou buscam se atualizar por meio de revistas semanais, nas quais a informação já está "empacotada" e analisada, pronta para o consumo.

A familiaridade com os recursos tecnológicos não representa um conhecimento mais aprofundado das possibilidades oferecidas pelo computador, já que o domínio de programas informáticos reside no nível básico para a maioria dos pesquisados da UNICSUL e no intermediário para a maioria da USP. O que percebemos é o desenvolvimento de um conhecimento intuitivo, guiado pela experimentação, característica da sociedade contemporânea, como já nos lembraram Orozco e MartínBarbero. Os autores esclarecem que a aprendizagem ganhou novas direções, rompendo a linearidade dos livros e a hierarquização dos conteúdos, para seguir um modelo de organização baseado na hipertextualidade, em que o sujeito busca o próprio conteúdo, em qualquer direção, aprendendo por meio da experimentação. E é exatamente esse saber experimental que identificamos nos futuros professores no que se refere à tecnologia, o que, por um lado, mostra-se bastante positivo, pois possibilita uma desenvoltura maior, evitando que eles fiquem paralisados diante de um novo recurso e estejam dispostos a explorá-lo. No entanto, por outro lado, o saber apenas experimental dificulta a articulação desse conhecimento com a profissão que escolheram. Os futuros professores, mesmo no final da graduação, sentem necessidade de formação para trabalhar outras linguagens em sala de aula. No caso especificamente dos meios de comunicação, acreditam que eles podem contribuir com o trabalho docente, porém não sabem como fazê-lo. Ficou evidente que o futuro professor está inserido no contexto audiovisual, mantendo intenso contato com as mídias. Os pesquisados demonstraram interesses que em geral envolvem o jovem em processo de escolarização, como programas televisivos de entretenimento, filmes de comédia e romance, e uso da internet para contato com outras pessoas. Há, portanto, um compartilhamento de campos de interesse que pode ser muito útil em sala de aula, para que o educador consiga estabelecer um diálogo com o educando. Porém o futuro professor necessita de orientação sobre como traduzir esse conhecimento em práticas de ensino. A princípio, 
identificamos que parte dos alunos já identifica disciplinas voltadas ao tema na graduação, porém ainda analisaremos esse tema de forma aprofundada na próxima etapa, onde combinaremos com os dados coletados nas entrevistas e na grade curricular.

Em relação ao perfil dos públicos das duas universidades, destacamos alguns pontos que revelam diferenças entre a instituição privada e a pública dentro de nossa amostra, formada por 86 pessoas:

- Os estudantes da UNICSUL formam um público mais maduro, com 44\% dos pesquisados tendo entre 26 e 40 anos, o que se reflete no percentual de casados (38\%) e com filhos (36\%). Já na USP há predominância do público mais jovem, com idade entre 20 e 25 anos (68\%). Consequentemente, há menos estudantes casados (15\%) e com filhos $(10 \%)$.

- Na USP, nenhum estudante declarou pertencer à etnia preta, enquanto que na UNICSUL esse grupo representa $9 \%$.

- Entre os estudantes que já trabalham em escolas, há uma "inversão": na maioria dos casos, quem estuda na universidade privada atua na rede pública, e quem estuda na pública atua em instituições privadas.

- Identificamos também que existe uma diferença socioeconômica entre os estudantes da universidade pública, localizada numa área central da cidade de São Paulo, e da universidade privada, localizada numa região periférica. Os estudantes da universidade pública têm renda média mensal mais elevada e, consequentemente, maior acesso a programas pagos, como cinema e TV fechada. No entanto, mesmo com a diferença socioeconômica, o acesso às novas tecnologias mostrou-se parecido nas duas universidades, com a grande maioria dos estudantes tendo computador e internet banda larga em casa. Esse fato em parte se explica pela necessidade de conexão gerada pelas aulas online da UNICSUL. Como a universidade oferece $20 \%$ de sua grade curricular a distância, os alunos precisam ter computador e internet à disposição para as atividades virtuais. Porém essa iniciativa, embora tenha o lado positivo de incentivar o uso do computador, causa polêmica entre os alunos pela forma como foi introduzida e pelo aproveitamento. Trataremos melhor desse tema no próximo capítulo. 


\section{CAPÍTULO VI - A interpretação dos dados}

Esta fase confere à pesquisa a condição própria de cientificidade. É o momento de teorização dos dados empíricos dentro da perspectiva discursiva adotada no início. Enquanto a análise descritiva converte os dados de fato em dados científicos, a análise interpretativa leva a análise a um nível superior de abstração e de generalização. É essencial que a pesquisa ultrapasse a fase descritiva e chegue à interpretativa para que ela tenha validade científica.

Lopes destaca que, nesta etapa, o ponto de chegada retoma dialeticamente o ponto de partida, integrando os dados numa totalidade que agora é igualmente objeto empírico e objeto teórico. Esse é o momento em que os dados, previamente organizados, são articulados com o quadro teórico de referência, permitindo chegar a conclusões e testar as hipóteses apresentadas.

É importante lembrarmos que os resultados da pesquisa não serão generalizados, pois estamos trabalhando com uma amostra não-probabilística. Os resultados são a constatação de um fenômeno num grupo específico, podendo funcionar como parâmetro para outras pesquisas e iniciativas.

\section{Formação na universidade}

Como vimos no capítulo anterior, a tabulação dos dados dos questionários mostrou que os estudantes de Pedagogia da USP e da UNICSUL identificaram em suas grades curriculares disciplinas voltadas ao estudo da comunicação na educação. Já os estudantes de Letras das duas universidades tiveram mais dificuldade para apontar disciplinas com esse propósito. Procederemos agora a um confronto desses dados com as propostas das disciplinas e os relatos obtidos por meio das entrevistas, de forma a verificar se de fato os cursos oferecem uma formação dentro desse recorte. Lembramos que nosso objetivo é verificar a formação voltada especificamente para a inter-relação comunicação/educação, portanto não consideraremos disciplinas que abordem a questão comunicativa somente em alguns momentos do curso, sem a terem como objetivo principal. A partir dos depoimentos dos entrevistados, foi possível perceber que alguns professores comentam eventualmente sobre o uso de meios de comunicação na escola, por exemplo, porém não é isso o que procuramos. Buscamos, na graduação, disciplinas pensadas e sistematizadas para trabalhar a educação vinculada à comunicação, integrando também os meios de comunicação como parte do currículo, já que eles são mediadores das experiências que o aluno leva para a escola. 


\subsection{Pedagogia - USP}

O curso de Pedagogia da USP apresenta duas disciplinas voltadas ao estudo da comunicação na educação: "Mídia e educação: um debate contemporâneo" e "Comunicação, educação e multimídia". A primeira foi citada uma vez no questionário; já a segunda foi apontada treze vezes nos questionários e amplamente comentada pelos entrevistados. Ambas fazem parte da grade curricular optativa do curso, estando entre as 104 disciplinas optativas eletivas, das quais os estudantes devem escolher 12 para cursar.

"Mídia e educação: um debate contemporâneo" tem a proposta de refletir sobre a mídia como agente socializador no mundo contemporâneo, ao lado de outras instituições de relevância, como a família e a escola. Também problematiza o limite e o alcance da indústria cultural. Embora tenha sido citada uma única vez no questionário e não tenha sido cursada por nenhum dos estudantes entrevistados, a disciplina se encaixa nos objetivos da inter-relação comunicação/educação. $O$ fato de não trazer uma abordagem prática sobre o uso dos meios de comunicação pode ter sido o motivo para a baixa adesão do grupo de estudantes pesquisados, porém consideramos uma importante disciplina, já que promove reflexão sobre os meios como elementos mediadores da sociedade, assim como a escola.

“Comunicação, educação e multimídia”, além de ter sido citada por $68 \%$ dos pesquisados no questionário, foi bastante comentada pelos entrevistados. A proposta da disciplina é analisar questões sobre comunicação e meios de comunicação (tradicionais e novos) na educação, vinculadas às práticas. Um dos objetivos é contribuir para a formação em comunicação e cultura midiática, dando subsídios ao futuro professor para a atuação pedagógica com os meios de comunicação contemporâneos e informatizados. Consideramos que esta disciplina é a que reúne de forma mais abrangente as propostas da inter-relação comunicação/educação, pois, ao mesmo tempo em que reflete sobre a vinculação dos campos, fornece condições para traduzir essa relação nas práticas de ensino. Esse aspecto prático na utilização de outras linguagens possivelmente foi o diferencial para a adesão dos estudantes, bem como o fato de trabalhar com as novas mídias. Uma das pessoas entrevistadas que cursaram a disciplina mostra-se animada ao contar como foi:

"Eu fiz a matéria, que foi optativa, do Agnaldo Arroio, sensacional. Inclusive foi de manhã, diferente do nosso horário, que é à tarde. Então ele pegava filmes - e falava 
que não era para assistir por assistir, não, tinha um foco - filme iraniano, que eu nunca tinha visto, que é outro tipo de linguagem. Ele dava programas, sátiras, aquela 'Terça Insana', então como você usa o humor, o que está por trás do humor, aí você já vai para o bobo da corte, para o palhaço, olha como você viaja com a coisa. Nessa matéria nós montamos uma aula em que tínhamos que trabalhar com audiovisual, então estávamos trabalhando com crianças de terceira série e meio ambiente. Nós pegamos os Sem Floresta. E trabalhamos 30 minutos do filme só, e tem 2 horas. Eu trabalharia com isso, não só com filme, com visita a museu, visita a parque, não ficar restrito à sala de aula. Dá mais trabalho? Dá. Mas a saída desperta, você faz a conexão do conteúdo com o que você está vendo no seu dia a dia." (G., USP)

O depoimento que acabamos de ler é de uma pessoa que não aprova a maioria dos conteúdos da TV aberta, no entanto, ela demonstra que a disciplina "Comunicação, educação e multimídia" despertou um novo olhar, fazendo com que refletisse sobre a possibilidade de levar programas de TV para a sala de aula, mesmo aqueles considerados, na opinião dela, ruins:

"Eu costumo assistir um programa aos domingos de manhã que é o Antena Paulista, que eu acho bem interessante, mas quem assiste isso? Eu, eu adoro. Agora uma criança não vai acordar domingo $7 \mathrm{~h}$ da manhã para assistir ao Tramontina falando. Então o professor Arroio conversou com a gente como você pode pegar um programa horroroso como o Big Brother e trazer pra sala de aula. Aí eu acho que é um trabalho muito grande do professor. Porque aí você vai trabalhar o quê? Relações humanas? Pra que tipo de público eu vou falar isso? Com crianças do primeiro, segundo ano? Pior é que elas assistem essa porcaria. Eu acho que é uma coisa que você pode fazer, mas o professor precisa ter muita bagagem pra saber como tirar. Dá pra pegar também esses programas do 'Pânico', em que falam tudo errado, e trabalhar numa aula de português: como é o certo? Se eu fosse falar com o diretor da escola, eu poderia falar desse jeito? Se tivesse que falar com o Presidente da República, eu poderia falar assim? Como eu devo falar com uma pessoa mais velha? Então eu acho que você pode pegar e usar o programa como pretexto pra entrar numa outra coisa. Você simplesmente chegar e dizer 'assiste ao Big Brother' não dá. Eu não assisto aquilo, não tenho paciência, mas se eu fosse professora teria que assistir porque meus alunos assistem.” (G., USP) 
Outra pessoa entrevistada que também cursou "Comunicação, educação e multimídia" diz que teve apenas essa disciplina voltada para o estudo da comunicação na educação, embora o assunto tenha sido abordado em alguns momentos em outras disciplinas:

“Tem uma só disciplina, que é uma optativa, 'Comunicação, Educação e Multimídia'. A gente leu uns dois capítulos sobre linguagem cinematográfica, o professor passou alguns filmes, a gente analisou e fez um estágio sobre professores que trabalhavam com história em quadrinhos. As matérias sobre mídias são mais as optativas mesmo. A gente tocou nesses assuntos em Didática, em Sociologia, falamos das mídias como um novo meio de socialização, e em Artes, mas não que estivesse dentro do programa, surgiu em discussões em aulas. Foi oculto.” (L., USP)

Embora discussões envolvendo os meios de comunicação estejam presentes em diferentes disciplinas ao longo do curso de Pedagogia, somente duas trabalham de fato com a proposta de estudar a inter-relação comunicação/educação. E essas disciplinas não pertencem à grade obrigatória do curso, indicando que o tema encontra-se à margem da formação dos futuros professores. No entanto, ainda assim, a Faculdade de Educação da USP é a que mais se envolve com a questão comunicacional entre as faculdades pesquisadas, pois, além das disciplinas optativas da Pedagogia, possui núcleos de pesquisa voltados ao assunto, bem como cursos de pós-graduação que refletem sobre a integração de comunicação e educação.

\subsection{Letras - USP}

Os questionários do curso de Letras da USP mostraram que os alunos não tiveram nenhuma disciplina voltada para o estudo da comunicação na educação, pois $86 \%$ responderam "não" à pergunta sobre o assunto, $9 \%$ não responderam e apenas $2 \%$ disseram "sim", o que representa uma única pessoa na amostra desse grupo, de 22 pesquisados. E essa pessoa não especificou qual seria a disciplina. Na segunda etapa da pesquisa de campo, pudemos comprovar o resultado, pois os seis entrevistados afirmaram que não cursaram disciplinas ligadas à comunicação durante o Bacharelado nem se lembravam de alguma oferecida pela grade curricular. Mesmo entre os que cursavam também Licenciatura (cinco entrevistados), ninguém soube apontar uma disciplina com esse propósito. Quando perguntamos especificamente sobre uma matéria 
que, em nossa análise inicial, poderia trazer uma abordagem sobre o assunto, porém não estaria voltada à perspectiva com a qual estamos trabalhando, apenas uma pessoa afirmou ter cursado. Ela fez muitos elogios ao que foi estudado e à professora, no entanto confirmou que a disciplina não tem como foco o estudo da comunicação na educação. Trata-se da disciplina "Introdução aos estudos da educação: enfoque sociológico", oferecida pela Faculdade de Educação aos cursos de Licenciatura. A proposta é examinar aspectos sociológicos das práticas escolares, oferecendo elementos fundamentais para a compreensão da especificidade da ação da escola ao lado de outras instituições educativas, como a família, os sistemas religiosos e a mídia, presentes na formação dos indivíduos na sociedade contemporânea.

"A disciplina mostrou que se coloca em cima da escola uma pressão muito grande para mudar o mundo, então o aluno é o aluno mal-educado, que não está aprendendo, o ensino público é ruim porque a culpa é do professor, o professor não dá aula direito, o professor não é preparado. Isso é um conjunto de fatores, é porque a sociedade não está funcionando bem, e a escola às vezes é um reflexo da sociedade. Se tem injustiça fora da escola, tem injustiça dentro da escola. Então é difícil colocar para a escola resolver tudo. O professor tenta se virar na comunicação com o aluno com o que ele pode. $\mathrm{O}$ aluno traz muitas vezes problemas pessoais pra sala de aula, então você tenta abrir espaço para o aluno falar de um problema pessoal e ao mesmo tempo você tem que ensiná-lo. Isso foi muito colocado na disciplina da Educação: o que mais interfere na relação professor-aluno? É só pra ensinar? Não, acaba não sendo. Tem aluno que está na escola por causa da merenda, pra não ficar na rua... Então a coisa vai além do ensino, a escola passa a ter muitas responsabilidades, e às vezes o ensino mesmo não entra porque fica um local de abrigo, não um lugar de conhecimento.” (V., USP)

O relato da pessoa entrevistada e a proposta mostram que a disciplina "Introdução aos estudos da educação: enfoque sociológico" traz uma importante contribuição para o professor refletir sobre o papel da escola, envolvendo a questão da mídia enquanto instância educativa, porém, como o foco não é o estudo da comunicação na educação, a disciplina não se encaixa em nosso recorte de trabalho. Identificamos, portanto, que o curso de Letras com habilitação em Português, tanto no Bacharelado quanto na Licenciatura, não oferece disciplinas cujo objetivo principal seja a inter-relação comunicação/educação. 


\subsection{Pedagogia - UNICSUL}

Na primeira etapa da pesquisa de campo, o questionário, os alunos de Pedagogia da UNICSUL, assim como os do mesmo curso da USP, apresentaram uma grande homogeneidade nas respostas: $85 \%$ dos pesquisados que afirmaram ter disciplinas voltadas à comunicação indicaram "Tecnologias da informação e da comunicação". A disciplina pertence à grade optativa do curso, que conta com nove opções. Sua proposta é discutir o papel das tecnologias da informação e da comunicação na formação do indivíduo e no espaço escolar, o que se encaixa no objetivo que estamos buscando. No entanto, os alunos entrevistados mostraram-se decepcionados com o conteúdo apresentado, pois, segundo eles, a disciplina oferecida ao longo de dois semestres concentrou-se na elaboração de mapa conceitual, não trazendo uma abordagem sobre a presença das tecnologias na educação.

"A gente pensou que ia chegar a mostrar como usar a tecnologia na educação, só que não, não teve nada a ver. A gente aprendeu a fazer mapa conceitual, dois semestres disso. A gente pensou que ia mostrar como levar a internet, computador, formas alternativas para o aluno que tem dificuldade, mas não. A gente foi reclamar, e a justificativa foi que, com mapa conceitual, era bem mais fácil você conseguir entender um texto. Tudo bem, superválido, mas o que isso tem a ver com a disciplina? 'Ah, é mais fácil quando você vai pra escola mostrar o mapa'. Tá, mas com aluno da primeira à quarta série, se eu mostrar mapa conceitual, vai entender? A explicação fugia da questão da tecnologia." (A., UNICSUL)

“Se é pra falar a verdade... Nós passamos um ano nessa disciplina aprendendo a fazer mapa conceitual. Eu acho que poderíamos ter aprendido a fazer mais coisas. Foi bom? Foi bom. Eu não sabia fazer mapa conceitual e hoje em todo lugar vejo isso. Foi bom, só que eu acho que poderia ter abordado outras coisas, ter sido uma aula que trouxesse mais elementos da parte tecnológica, por que não é t-e-c-n-o-l-o-g-ia da informação? Então a única coisa que nós fizemos durante um ano, dois semestres, foi fazer mapa conceitual. Poderia ter sido melhor.” (C., UNICSUL)

“A gente fazia muito mapa conceitual, então acho que a gente tem que trabalhar um pouco mais a questão tecnológica para ver como vai aplicar. Eu tinha expectativa de 
aprender a mexer mais, mas não, foi mais como que eu poderia usar o mapa conceitual para interpretar os textos." (M., UNICSUL)

Além de terem falado sobre "Tecnologias da Informação e da Comunicação", durante as entrevistas, os estudantes de Pedagogia comentaram também sobre "Educação não-formal", citando-a como um exemplo de disciplina que ampliou os horizontes sobre a compreensão do processo educativo, pois mostrou que ele não se restringe à escola.

“A gente está tendo neste semestre e eu estou adorando porque é aquela coisa da educação na igreja, educação em ONGs. A gente está conseguindo ver o que é educação não-formal, uma educação que não está dentro da escola, mas está educando.” (A., UNICSUL)

'Estou fazendo 'Educação não-formal' e gostando muito. Você vê que existem outras instituições, não só a escola, que podem auxiliar a aprendizagem. E não só a aprendizagem, porque existem muitas instituições que auxiliam o aluno, a família do aluno, dão vários tipos de suporte, não só no ensino-aprendizagem. Tem esporte, tem lazer, tudo isso. E eu não tinha noção de que existiam tantas instituições. A gente sabe alguma coisa, ouve falar das mais famosas, como instituto Ayrton Sena, mas em bairros a gente não conhece e descobre que tem. (C., UNICSUL)

A disciplina certamente contribuiu para superar um dos estereótipos citados por Orozco, o de que a escola é a única instituição legítima para educar, pois apresentou as possibilidades de educação não-formal. No entanto, como não é abordada também a questão da educação informal, onde se inserem os meios de comunicação, a disciplina não se encaixa no recorte com o qual estamos trabalhando. Temos, portanto, no curso de Pedagogia da UNICSUL, uma disciplina cuja proposta atende à perspectiva da interrelação comunicação/educação, "Tecnologias da Informação e da Comunicação". Porém, segundo os alunos entrevistados, essa disciplina não atinge a expectativa de ensinar a trabalhar outras linguagens na escola. 


\subsection{Letras - UNICSUL}

O curso de Letras da UNICSUL foi o que apresentou maior oposição entre aqueles que dizem ter disciplinas voltadas para o estudo da comunicação na educação e aqueles que dizem que não. Entre os que responderam essa opção no questionário, $52 \%$ disseram "não" e 48\%, "sim". Na questão seguinte, uma pergunta aberta para informar o nome da disciplina, mais uma vez houve uma grande variação nas respostas, como vimos na tabulação dos dados, com a indicação de disciplinas que não correspondiam ao propósito da questão. A que mais poderia se aproximar, à primeira vista, de nosso objetivo seria "Linguagem e Tecnologia", porém a disciplina foi removida da grade curricular de Letras após reforma implantada em 2010. Além disso, a proposta da disciplina era desenvolver a capacidade de leitura do mundo do graduando por intermédio do estudo da relação linguagem/cultura e tecnologia, com foco no aprimoramento da capacidade de produção e leitura dos diversos gêneros textuais. Não havia, portanto, objetivo voltado especificamente à comunicação, apesar de trabalhar com outras linguagens. Uma das pessoas entrevistadas disse que houve uma abordagem sobre blogs, mas destacou que esse não era o foco:

"A professora falou sobre criação de blog, acho incrível isso, ensinou um pouco da história da língua portuguesa, mas o principal dessa disciplina era a intertextualidade, o dialogismo bakhtiniano. Diálogo que um texto pode fazer com uma música e que pode fazer com um quadro, intertextualidade mesmo, era o foco dessa disciplina." (B., UNICSUL)

“Como era uma professora de semiótica, então essa disciplina foi muito produtiva porque fez uma conexão da linguagem verbal com a linguagem não verbal, com teorias, nos introduziu a certos filósofos, a certos educadores, pensadores, os quais eu não conhecia." (J., UNICSUL)

A partir das entrevistas, foi possível identificar que a questão sobre o uso dos meios de comunicação e das novas tecnologias na escola perpassa algumas aulas, porém sem que o assunto esteja sistematizado em uma disciplina específica: 
"Na aula de Metodologia, a professora fala bastante de usar diferentes recursos, de comunicação. $\mathrm{Na}$ aula de Libras também, a gente tem que usar bastante a internet pra pegar materiais, tem que usar bastante dessa comunicação virtual.” (N., UNICSUL)

Não encontramos, portanto, no curso de Licenciatura em Letras com habilitação em Português/Inglês da UNICSUL, disciplinas voltadas para a inter-relação comunicação/educação.

A partir das informações apresentadas, constatamos que o curso de Pedagogia da USP é o que mais se aproxima da proposta de uma formação regular docente que efetivamente vincule os campos da educação e da comunicação, pois oferece duas disciplinas voltadas ao tema. No caso de "Mídia e Educação: um debate contemporâneo", não pudemos comprovar se, ao ser ministrada, a disciplina atendeu à proposta, pois nenhum dos entrevistados havia cursado, mas, em sua definição, ela se encaixa perfeitamente em nosso recorte. Já a disciplina "Comunicação, Educação e Multimídia”, por sua vez, não apenas se insere em nosso recorte devido à sua definição, como de fato cumpre a proposta ao ser ministrada, como pudemos comprovar a partir das entrevistas. A disciplina consegue reunir aspectos reflexivos e práticos, contribuindo para que o futuro professor exercite um novo olhar e ao mesmo tempo saiba traduzir o aprendizado em suas práticas de ensino. Dessa forma, poderá, no futuro, ajudar o aluno a também desenvolver novos olhares. No entanto, ambas as disciplinas fazem parte do currículo optativo, sendo oferecidas juntamente com outras 102 disciplinas, das quais o graduando deve escolher 12. A formação para a comunicação, portanto, não está plenamente integrada à graduação em Pedagogia da USP, embora este seja o curso que mais se aproxime da proposta em nossa pesquisa. Reconhecemos, no entanto, que essas disciplinas, ainda que optativas, representam um avanço na formação de professores. A graduação em Pedagogia da UNICSUL também apresenta um avanço no que se refere à proposta do curso, pois se dispõe a estudar as tecnologias da informação e da comunicação no espaço educativo, no entanto, além de a disciplina também ser optativa, ela não atende às expectativas dos futuros professores. Já os cursos de Letras da USP e da UNICSUL nem ao menos se aproximaram da proposta, pois não possuem qualquer disciplina que integre os campos da educação e da comunicação. Percebemos, portanto, que a formação inicial docente ainda não incorporou a abordagem comunicativa. Quando existe uma movimentação nesse sentido, ela ainda se 
encontra circunscrita à grade opcional dos cursos, sem uma efetiva integração à matriz curricular. Consequentemente, o problema apontado por Citelli tende a se reproduzir: a qualificação docente não prepara o jovem professor para interagir dialogicamente com as dinâmicas transformadoras da sociedade, fazendo com que "o jovem professor ingresse na carreira no contrapé das experiências com os meios de comunicação e com as novas tecnologias já desenvolvidas pelos alunos" (CITELLI, 2000: 30).

\subsection{Formação mais específica}

Como apontou a análise descritiva, $86 \%$ dos pesquisados gostariam de receber uma formação mais específica para trabalhar com os meios de comunicação em sala de aula. Nas entrevistas, ao descreverem sobre o que gostariam de aprender, a maioria dos participantes focou o interesse nas novas mídias.

"Um ponto que me preocupa é a internet porque eu não sei até que ponto eu vou conseguir utilizá-la de uma forma legal para os alunos aprenderem ou não. Porque ela tem um mundo de informações, mas nem tudo é verdadeiro.” (A., USP)

"Eu gostaria de aprender mais sobre como usar o computador para o ensino. Por exemplo, eu tenho dificuldade, eu sou da fase de transição - hoje em dia você pega um adolescente que tem blogs interessantíssimos e não passou por nenhum curso - então eu preciso de um embasamento teórico, de algumas coisas que eu infelizmente não tenho. E como aplicar isso em sala de aula. Associar a tecnologia à forma de ensinar. As crianças são hoje altamente visuais. Como disse uma professora, estudos comprovam que a plasticidade do cérebro mudou, então eles são altamente perceptivos. Então, se o professor não captar isso, não voltar suas aulas pra isso, vai ser um ensino desmotivado, um ensino sem sentido." (J., UNICSUL)

"Quero aprender a fazer estudo a distância: como é que eu faço educação a distância? A faculdade não tem.” (G., USP)

"Eu acho que tinha que ensinar a usar o recurso tecnológico e como aplicá-lo em sala de aula." (R., UNICSUL) 
Os pedidos de formação mais específica muitas vezes se concentram nos suportes, resultado da visão instrumental que abordaremos adiante, porém revelam a dificuldade do futuro professor de integrar as novas tecnologias às práticas de ensino. Embora a questão tecnológica tenha sido a mais requisitada, houve também quem solicitasse uma formação envolvendo um meio tradicional, o rádio:

"Eu acho que um recurso muito legal, que eu gostaria de aprender a mexer melhor, é o rádio. Eu tentei fazer isso com os alunos, afinal, rádio é um meio de comunicação incrível para a comunidade. Rádio existe há quanto tempo? Não estou falando de internet, de infográfico, estou falando de rádio, que meu avô ouvia. Então tem as rádios comunitárias. E rádio é barato. Então minha ideia era dividir em grupos e fazer um programa de rádio em que eles iam produzir o roteiro, a sonoplastia, a locução tudo. Usamos um gravador comum e minha ideia era gravar um CD para cada um, e quem sabe despertar em alguém a vontade de produzir, que eles pudessem bater na porta de alguma rádio, enfim, a ideia era dar voz para aquelas pessoas. Só que o áudio ficou uma porcaria, foi uma confusão, mas eles se divertiram muito. Eles ficaram encantados de poder produzir alguma coisa. Tinha muita gente com vergonha, aí obrigaram a gente a fazer uma apresentação disso, mas tinham muitos grupos, ninguém mais aguentava ouvir isso na plateia, então foi um desastre do ponto de vista do público. Então talvez uma formação para uma coisa assim, em que você consiga pôr na mão do aluno o instrumento e não só o produto acabado. Isso faz com que eles pensem nos meios de comunicação, na relação deles com os meios de comunicação, faz com que eles organizem o próprio discurso, faz com que eles pesquisem porque eles não querem falar qualquer bobagem naquele programa, então isso mexe com uma série de questões, faz com que eles vão atrás de outras informações, faz com que eles ouçam outras pessoas se houver entrevista, eles treinam o poder de síntese. Eles conseguem reorganizar um mundo que é muito desorganizado e bagunçado para todos nós." (O., USP)

A percepção da pessoa entrevistada condiz com a proposta da Educomunicação, defendida por Ismar de Oliveira Soares: dar voz aos alunos; e o rádio é um meio poderoso nesse sentido. Inclusive o Núcleo de Comunicação e Educação da USP, coordenado por Soares, desenvolve o projeto EDUCOM.RÁDIO, voltado à capacitação de estudantes e professores para a implantação e gestão educacional de rádio na escola. 
Assim como apontou O., a produção radiofônica pode promover um novo olhar e desenvolver diversas habilidades, já que envolve o trabalho com outras linguagens e incentiva a capacidade de expressão, além de aproximar professor e aluno. Trata-se de um meio tradicional, agora ancorado em novas tecnologias, como o uso de gravadores digitais, de programas de edição no computador, gravação de CD para reprodução ou transmissão via internet. O importante, como bem sugeriu a entrevistada, não é o suporte em si, mas a mediação promovida pelo meio, levando à reflexão e ao aprendizado.

\subsection{Visões sobre a graduação}

Ainda que nosso objetivo tenha sido investigar a formação do professor para a comunicação, consideramos importante verificar também se o futuro professor sente-se preparado para a prática docente e qual a contribuição da universidade. Durante as entrevistas, pudemos identificar dois posicionamentos distintos: os estudantes da UNICSUL mostraram-se bastante satisfeitos com a formação oferecida na graduação, enquanto que os alunos da USP adotaram um posicionamento mais crítico em relação ao ensino de práticas docentes.

$\mathrm{Na}$ UNICSUL, a grande maioria dos entrevistados avaliou de forma positiva a formação ligada à didática, e muitos fizeram questão de ressaltar que foram aprovados em concursos graças à preparação universitária. Reproduzimos a seguir alguns exemplos:

"A didática de ensino acredito ser excelente. A universidade preparou muito bem. Já leciono, sou eventual na rede estadual, e não tive nenhum grande susto quando cheguei. Óbvio, algumas situações são diferentes das que foram faladas aqui, no entanto você tem um embasamento teórico forte aqui e consegue levar as aulas na rede pública. Então acho que a formação foi bastante coerente. Inclusive naquela prova do Estado eu acabei nem estudando e fiquei em oitavo lugar na colocação porque eu lia e já identificava com as aulas.” (B., UNICSUL)

“A formação daqui é ótima, tanto que da vez que eu prestei concurso foi perfeito, tudo o que eu tive estava lá. E eu acredito naquilo que estava sendo solicitado ali na prova, as metodologias, a didática, eu acho ótimo.” (L., UNICSUL) 
"Eu achei muito bom. Eles ensinam maravilhosamente bem, tem professores que motivam a gente a entrar na sala de aula. A professora de Metodologia, por exemplo, mostra outros tipos de coisas pra gente, que o livro didático é interessante levar, pode ser levado, mas que pode ter um conteúdo melhor, mais fácil pros alunos e tudo, eu acho que isso é legal. Ela conta as experiências dela, ela motiva o aluno, ela explica, mas sempre respeitando a opinião do aluno. Ela traz coisas diferentes pra nós estudarmos e fala sobre as experiências dela. E eu levaria a metodologia dela pra sala de aula.” (R., UNICSUL)

Apenas duas das pessoas entrevistadas (uma de Letras e uma de Pedagogia) disseram que a preparação deixou a desejar no aspecto das práticas de ensino:

“Acho que o conteúdo fica centrado em algumas coisas muito voltadas para a linguística. Aí com relação à sala de aula mesmo fica um pouco distante. Eu sinto falta de uma preparação maior para dar aula. Fica muito naquela parte de análise do discurso. Muita matéria relacionada à linguística.” (O., UNICSUL)

"Da parte da didática eu esperava um pouco mais, mas eu acho que na verdade a gente só aprende na prática. A teoria é importante, mas as aulas sobre as formas de ensinar ficaram um pouquinho a desejar. (C., UNICSUL)

Na USP, diferentemente, grande parte dos estudantes demonstrou uma postura crítica em relação à formação como professor, e alguns falaram espontaneamente que não se acham em condições de dar aula:

"Não me sinto preparada para dar aula, não. Tive algumas matérias de didática, mas não aprendi nada, para falar a verdade." (C., USP)

"Eu acho que tem muita base teórica, eu me sinto absolutamente capaz de pensar a respeito de tudo, mas implementar, fazer atividades práticas, nenhuma.” (J., USP)

"Eu acho que a formação como professor aqui na USP está complicada. Não é assim que deveria ser porque eles estão formando com aquela visão de formar pesquisador, e não profissional, mas tem gente que quer entrar aqui para sair como 
profissional, não só como pesquisador, ou não como pesquisador. Lógico que é importante ter as coisas que a gente aprende aqui, é muito importante para a gente aprender a analisar a língua como ela é, mas não excluir aquela outra parte que a gente vai usar profissionalmente. É isso o que eu mais sinto falta, acho que a formação como professor aqui na USP está sendo deixada de lado. E acho que ela não deveria ser deixada de lado não pelo fato que a gente deveria formar aluno de Letras só para dar aula, isso também não, mas acho que não deveria ser excluída essa parte. A única razão que eu vejo é por orgulho, de não querer formar aluno de Letras para ser professor. É querer formar aluno de Letras para fazer pesquisa. É importante isso, lógico que é muito importante você ter produção científica, mas tem aluno que quer ser professor." (D., USP)

"Infelizmente, você sai da faculdade sem saber a prática. Você tem muita teoria e prática mesmo você não tem. No curso de didática, nós estudamos os pedagogos. E aí? É importante saber os pedagogos? Sim, mas vamos fazer isso então no primeiro semestre e no segundo semestre ensinar as técnicas que eu posso usar pra ensinar uma criança. Então isso fica um pouco frustrante. A prática. Foi o que o professor falou: a orientação da faculdade é teórica. E nós chegamos e falamos: 'professor, e a prática?'. 'Nós não vamos ver isso, não é o foco da faculdade, nós estamos numa academia'. Eu acho que quando faz o vestibular a gente não vem para uma academia, a gente vem para uma faculdade, mas..." (G., USP)

As duas últimas declarações são de estudantes de cursos distintos, um de Letras e um de Pedagogia, e ambos sentiram a mesma necessidade: uma formação mais voltada à prática docente, pois consideram que, embora tenham uma grande bagagem acadêmica, não encontram o vínculo com o exercício da profissão. A crítica dos alunos aproxima-se do que discutimos com Perrenoud, ou seja, a realidade da sala de aula deveria ser trazida aos cursos de graduação, descrevendo as condições e as limitações do trabalho dos professores e buscando formas de contornar as dificuldades. "Em diversos sistemas educacionais, há queixas de absenteísmo, de falta de educação e até mesmo da violência dos alunos, de sua rejeição ao trabalho, de sua resistência passiva ou ativa à cultura escolar. Em que programas de formação inicial a amplitude desses problemas é levada em consideração?" (PERRENOUD, 2002: 17). Não se trata, como já destacamos, de negligenciar a reflexão, a discussão, a teorização, mas de trazer 
também os dilemas e desafios da prática docente, buscando encontrar caminhos para apaziguar conflitos e criar um ambiente que permita fluir o aprendizado. E o trabalho com outras linguagens pode ser um desses caminhos, uma forma de superar a rejeição ou resistência do aluno à atividade escolar. Afinal, os meios de comunicação e as novas tecnologias não correspondem a mais uma "ferramenta" que o professor pode usar, e sim constituem-se como elementos mediativos do processo educacional.

Uma das pessoas entrevistadas acredita que não só a prática deve ser trazida para a universidade, como também a universidade deve dar um retorno à prática, oferecendo uma contribuição efetiva. E, para que isso possa ser realizado sem prejudicar a pesquisa acadêmica, ela sugere uma divisão no curso de Pedagogia de acordo com o interesse:

“A educação é muito ampla, você tem a parte prática em sala de aula, a parte de gestão e a parte de pesquisa, que é importante também. Então, no primeiro ano o aluno faz o básico, no segundo você já dá uma certa mesclada, no terceiro e quarto ano a coisa é focada. Eu acho que a faculdade ganharia muito com isso porque infelizmente a gente percebe as críticas duras e corretas que a imprensa faz em relação à faculdade de Pedagogia da USP. Já saíram matérias, os professores contestaram, mas infelizmente a gente peca porque a gente não consegue contribuir na prática com a educação, infelizmente. Eu acho que você tem que olhar o que a sociedade precisa. Infelizmente, estamos encarcerados na realidade acadêmica. A educação é a base para você fazer as coisas; para você pensar, é preciso ter uma educação. Então a sociedade está precisando de alguma coisa e a gente aqui fica se preocupando muito com a teoria. Não se dá nada prático, não se encanta as pessoas para irem para essa área, não mostram possibilidades: como é que eu reverto essa situação? Então no mundo em que nós estamos hoje, como é que se inverte isso? Não é só fazer crítica. Você tem que fazer uma crítica, e você tem que oferecer uma outra coisa. Por exemplo, critica-se o projeto Ler e Escrever. Tudo bem. O que você dá em troca? Nada. Então eu acho que não é só fazer a crítica; você tem que fazer a crítica e oferecer uma alternativa. E uma alternativa mais concreta, mais palpável, uma coisa que você possa fazer. Não simplesmente ficar na discussão pela discussão.” (G., USP)

O relato nos leva ao que discutimos com Nóvoa: há um excesso de discursos na área educacional que frequentemente esconde uma pobreza das práticas. "Temos um discurso coerente, em muitos aspectos consensual, mas raramente temos conseguido 
fazer aquilo que dizemos que é preciso fazer" (NÓVOA, 2009: 17). O autor propõe reforçar as práticas de formação docente baseadas numa investigação da ação dos professores na sala de aula e do trabalho escolar. A questão da prática não representa uma perspectiva anti-intelectual na formação dos professores, mas sim uma aproximação com o dia a dia da profissão: "Trata-se, sim, de afirmar que as nossas propostas teóricas só fazem sentido se forem construídas dentro da profissão, se forem apropriadas dentro de uma reflexão dos professores sobre o seu próprio trabalho. (...) Parece que todos sabemos, e até concordamos, com o que deve ser o futuro da profissão docente. Mas temos dificuldade em dar passos concretos nesse sentido" (NÓVOA, 2009: 19).

A partir das entrevistas sobre a formação oferecida na graduação, pudemos perceber uma postura de contestação dos alunos da USP no que se refere à formação enquanto professores, mas eles também reconhecem as importantes contribuições da universidade:

"Eu estou satisfeita com meu curso. Os professores são exigentes, você tem mesmo que ler os textos. Estou satisfeita com os conteúdos. É difícil, mas tem uma carga cultural muito grande. Estou muito satisfeita, faria de novo.” (M., USP)

"Apesar de eu achar que a qualidade das aulas depende muito do professor, porque tem professor que você percebe que chega aqui e não planejou aula nenhuma, de uma forma geral eu aprendi bastante coisa. Se eu analisar o que eu cheguei até hoje, já aprendi muita coisa sobre teorias, sobre autores, eu sinto que vou sair com um bom capital de conhecimento daqui." (A., USP)

Na UNICSUL, por sua vez, os estudantes defenderam a universidade desde o primeiro momento, e acreditamos haver dois motivos para essa postura: o fato de eles realmente gostarem da universidade e sentirem que ela faz diferença em suas vidas, e a disposição em não desmerecer o próprio curso diante da pesquisadora. Essa situação acontece num momento inicial, pois em geral a entrevista começava com o aluno contando um pouco sobre sua história e sobre o que achava da universidade. Percebemos que o fato de a pesquisadora vir de uma universidade pública causou intimidação em alguns estudantes. Ao iniciar a conversa com uma das pessoas pesquisadas, ela disse: 
"Eu não sei falar aquelas palavras bonitas que vocês usam lá na USP, não.” (R., UNICSUL)

Outra pessoa fez questão de ressaltar que seu curso era ótimo "mesmo não sendo de uma universidade pública" e destacou que ela própria tinha preconceito em relação à universidade privada:

"Eu me surpreendi bastante com o curso. A formação daqui é ótima, mesmo não sendo de uma universidade pública. Eu até vim com um certo preconceito, 'ai, meu deus, UNICSUL', mas a formação daqui é ótima.” (L., UNICSUL)

No decorrer da conversa, no entanto, os entrevistados passaram a falar mais abertamente e expor também os pontos em que a universidade poderia melhorar, pois a questão da formação esteve presente em diversos momentos da entrevista:

"Nossos testes são de múltipla escolha, nenhuma questão dissertativa. Nós estamos num curso de Letras, então o poder de argumentação tinha que ser melhor trabalhado. A grande maioria dos nossos testes é de múltipla escolha. Essa é uma crítica aos professores. 'Forças sobrenaturais' mantêm uma certa estrutura, e na minha opinião é a qualidade dos alunos que chegam à universidade. A qualidade dos alunos é que contribui para manter essa estrutura porque uma prova de múltipla escolha te dá condição de chutar, colar, de complementar com um trabalho, então você tem diversos meios para levar em banho-maria. Agora, quando você tem que se expressar realmente fica mais complicado, você tem que argumentar, usar tudo o que realmente aprendeu." (J., UNICSUL)

As conversas sobre as disciplinas ensinadas na universidade ficaram para o final das entrevistas, quando os estudantes já estavam mais à vontade com a pesquisadora e, como vimos, fizeram algumas críticas quanto ao não cumprimento da proposta. Depois de desligado o gravador, alguns perguntaram mais detalhes sobre a pesquisa, e uma das pessoas entrevistadas disse que teve receio de participar ao saber que era para a USP, porque ela poderia não saber "as respostas". Outro entrevistado comentou que pretendia fazer mestrado; a pesquisadora perguntou se ele iria tentar na USP e ele respondeu que 
não "porque não tinha chance". Disse que a universidade pública "não era para eles, que moram na periferia", pois, como ele não tinha "nenhum contato" dentro da universidade, jamais conseguiria fazer um mestrado lá. Comentários como esses mostram que a universidade pública é vista muitas vezes como algo intangível, o que aumenta nossa responsabilidade, enquanto pesquisadores oriundos de uma instituição pública, de não reproduzir um discurso excludente que muitas vezes parte de dentro da própria instituição. Como exemplo, trazemos um comentário de uma das pessoas entrevistadas na USP. Ela contestava a obrigatoriedade de comprovar as atividades acadêmico-científico-culturais, exigidas pelo Ministério da Educação aos cursos de Licenciatura, na universidade:

"A gente tem uma matéria que chama AACC, que é pra comprovar nossas atividades sociais, culturais, que eu acho um absurdo porque a gente já faz muita coisa aqui. Eu acho que todo mundo aqui, pelo menos na Letras, todo mundo vai ao teatro, vai ao cinema. Atividade acadêmica a gente é obrigado a fazer, a gente participa de congresso. E a gente tem que comprovar tudo agora. São 200 horas para comprovar este ano. Eu acho ridículo isso, um absurdo. Eu até concordo que em faculdade particular a maioria dos alunos não faz esse tipo de coisa, tem muitos alunos que não têm vida cultural, pelo que eu conheço. Mas aqui, não, a gente já faz isso, não precisa comprovar." (N., Letras)

Com o exemplo, não pretendemos entrar no mérito da discussão sobre as atividades acadêmico-científico-culturais, mas evidenciar um discurso que, ao mesmo tempo, estigmatiza as pessoas que cursam a universidade privada e defende um "privilégio" a quem está na universidade pública: quem estuda na USP não precisaria comprovar as atividades, os "outros", sim. Certamente esse tipo de discurso estigmatizado muitas vezes também parte de dentro da universidade privada, como já pudemos observar no comentário do entrevistado que associou o método de avaliação, considerado por ele ruim, à "qualidade" dos alunos da UNICSUL. Da mesma forma, no caminho inverso, não podemos reproduzir um discurso que aponta a universidade pública como voltada exclusivamente à elite, cujos alunos teriam plenas condições de pagar pelo ensino superior. Realmente, os dados do questionário indicam uma renda mensal mais elevada dos estudantes da USP em relação aos da UNICSUL, porém a universidade pública está aberta a todos, independentemente da classe social. Aqui 
teríamos que entrar no mérito dos processos seletivos e da qualidade do Ensino Fundamental e Médio, o que ampliaria demais a discussão, fugindo dos nossos objetivos. O que nos interessa é mostrar que a pesquisa de campo nos deixou ainda mais alerta ao risco de aderir ao discurso do senso comum e que temos procurado, ao longo da interpretação dos dados, romper com essas visões.

Para nos mantermos dentro do discurso científico, buscamos sempre exercitar a "vigilância epistemológica", questionando nossas impressões, afinal, como fala Lopes, "o importante não é o que se vê, mas o que se vê com método, pois o investigador pode ver muito e identificar pouco e pode ver apenas o que confirma suas concepções" (LOPES, 2005: 143). O levantamento prévio sobre o ensino superior no Brasil, apresentado no Capítulo V, contribuiu para elucidar o cenário de pesquisa e ampliar nosso contexto de reflexão, pois já pudemos descartar uma visão equivocada que tínhamos: a de que a grande maioria dos profissionais da área de Educação era formada por universidades privadas. Pensávamos existir uma diferença gigantesca entre o setor público e o privado, no entanto, verificamos que o cenário não é bem este. Realmente, quando avaliamos o número total de cursos de graduação oferecidos no Brasil, a diferença é gritante: $73 \%$ são oferecidos por instituições privadas, e $27 \%$ por públicas, segundo o Censo Escolar da Educação Superior no Brasil divulgado em novembro de 2009 pelo INEP (Instituto Nacional de Estudos e Pesquisas Educacionais Anísio Teixeira), do Ministério da Educação. Porém, quando fazemos o recorte na área com a qual estamos trabalhando, essa proporção muda bastante: $56 \%$ dos cursos de graduação da área de Educação são oriundos de instituições privadas, e $44 \%$ de públicas. A diferença, portanto, é de $12 \%$. A surpresa foi ainda maior no caso da formação de professor de matérias específicas, em que se inclui o professor de português: há uma leve predominância de instituições públicas. A diferença é mínima, porém suficiente para derrubar nossas "impressões": $50,46 \%$ dos cursos de graduação que formam professores de matérias específicas, como biologia, português, matemática etc., são oferecidos por instituições públicas. Os dados detalhados encontram-se no Capítulo V e muito nos ajudaram a romper com o senso comum, fazendo com que chegássemos à interpretação dos dados com um olhar mais preciso e menos viciado sobre a formação de professores. 


\section{Produção de sentidos e comunicação}

Além de pesquisarmos a formação universitária do futuro professor, investigamos também suas visões sobre o ensino e a inter-relação comunicação/educação. Uma questão bastante presente nas preocupações dos entrevistados é o sentido. Eles superam a visão da "educação bancária" apontada por Paulo Freire, acreditando que o papel da educação formal não é simplesmente "encher" o aluno de conteúdo, mas sim ajudá-lo a construir sentido a partir do que está estudando. Os pesquisados defendem um ensino contextualizado, que leve em consideração o dia a dia do educando, dentro e fora da escola. Eles acreditam na educação para a significação, no processo educativo enquanto produção de sentido:

"É preciso contextualizar o que é ensinado. Fazer com que a educação faça sentido porque de nada adianta você passar coisas que não façam sentido na vida." (J., UNICSUL)

“O aluno deve se perguntar 'por que estou aqui?'. Você teria que mostrar uma utilidade para aquele conhecimento. Deveria ser mostrado para o aluno por que ele está ali." (V., USP)

“A grande questão é tentar entender por que aquilo está lá, por que a gente tem que estudar o Cabral, por exemplo. Qual a importância do estudo da História, a importância de estudar Geografia, Português, entender por que é isso que está no currículo e não outras coisas. Eu acho que muito do que está no currículo é legal estar lá, só que contanto que isso seja avaliado o tempo todo porque o mundo vai mudando, e a escola é uma instituição contemporânea, ela tem que se adaptar o tempo todo, não se adaptar no sentido de que ela tem que se submeter, mas no sentido de caminhar junto com a evolução e não se tornar obsoleta." (L., USP)

“O professor precisa verificar que o mundo não parou lá atrás, que não se bate mais com palmatória, que não se manda mais decorar tabuada. Ele tem que verificar que o conhecimento evoluiu de certa forma e tem que ser aplicado na vida desse aluno porque senão fica uma coisa descontextualizada, que nem a alfabetização antigamente: 'a vaca baba'. E daí? O aluno que assistiu a vida inteira a televisão, filmes, tudo isso, ele vai virar pra você e falar assim 'posso falar com o seu líder?'. Uma criança de sete anos 
é capaz de falar isso porque ela já assistiu a muitos filmes. E você vem com 'a vaca baba'? Que função tem o ensino nesse sentido se é descontextualizado? Se não serve para o aluno, ele descarta da sua vida.” (B., UNICSUL)

"Eu acho que não adianta você colocar muita coisa na cabeça, ensinar de forma rasa e sem explicar por que a criança está aprendendo aquilo. Mostrando que você vai usar aquilo no seu dia a dia, você desmitifica a coisa, faz com que a pessoa tenha interesse. Se você apresenta uma coisa que você possa vivenciar no seu dia a dia, que é o que a teoria construtivista fala - você trazer o seu dia a dia - eu acho que é mais proveitoso. Por que em vez de eu ensinar quais são as capitais do mundo, não faz um jogo? Ou não aproveita um evento? Nós vamos ter a Copa do Mundo, então agora é hora de ensinar esse tipo de coisa. Você pode jogar, brincar, para ensinar determinados conteúdos, você tem que mostrar por que a pessoa tem que aprender aquilo. Não simplesmente aprender para decorar, fazer uma prova e esquecer." (G., USP)

"Muitas vezes, na sala de aula os alunos acabam encontrando uma coisa que não é real, uma aula que eles não estão acostumados. Então, quando você leva desde jornal, revista a vídeos, filmes, é uma forma de chegar mais próximo do cotidiano do aluno. Tem que discutir coisas que eles estão vendo que estão acontecendo, não uma coisa muito longe da realidade deles." (N., USP)

Quando se referem ao aprendizado dos alunos, os futuros professores compreendem que a palavra adquire significação no contexto em que está inserida, não havendo, portanto, sentido predeterminado, como discutimos com Bakhtin e Wittgenstein. O intervalo social em que as diferentes vozes se tensionam é que permite a constituição de campos de sentido; a significação se faz no jogo entre emissão e recepção dentro das interações contextuais, com interferência dos elementos mediativos. As falas apresentadas já trazem espontaneamente os meios de comunicação juntamente com a necessidade de contextualização, sinalizando que os futuros professores percebem que a mídia é um dos elementos mediativos na construção de sentido. As experiências adquiridas pelos alunos fora do espaço escolar, especialmente a partir do contato com os meios, são apontadas pelos pesquisados como fatores que interferem no aprendizado. Como lembra Orozco, a recepção das mensagens ocorre além dos limites 
da casa onde vivem os alunos, num processo que se estende à escola e retorna ao lar, gerando uma troca de impressões e significados.

Os entrevistados de nossa pesquisa reconhecem a sala de aula como um espaço cruzado por mensagens, signos e códigos que não se restringem ao espaço escolar, como discutimos com Citelli. O autor destaca que, com a dispersão e fragmentação do saber geradas pelos meios de comunicação e pelas novas tecnologias, ele escapa ao controle das instâncias historicamente legítimas de circulação, como a escola, o professor e o livro, ocorrendo um desencontro entre o discurso didático-pedagógico, fortemente centrado na oralidade, e as linguagens institucionalmente não escolares, como a da TV e da internet. No entanto, essas outras linguagens pressionam do lado de fora, e a escola deveria incorporá-las ao seu discurso, passando a reconhecer e orientar o conhecimento adquirido pelos estudantes nos novos fluxos comunicacionais. Essa percepção é compartilhada pelos futuros professores, que acreditam ser fundamental a aproximação com a linguagem do aluno para o sucesso do processo educativo, o que implica trazer os meios para a escola.

“As mídias estão aí, e os alunos querem muito isso, querem internet, TV, revistinhas. Crianças de três anos já trazem revistinhas e álbum de figurinhas para a escola. Eu acho que a educação tem mais é que acolher isso e saber trabalhar com isso, seja de uma forma crítica ou de se apoiar mesmo nessas coisas. Vamos entender por que isso está acontecendo em vez de simplesmente vetar: 'não, não pode trazer revistinha'. E faz parte da socialização também, não dá para excluir isso. E a comunicação seria mais um meio de aproximação até dos conteúdos pros alunos. Por exemplo, vamos estudar a história contemporânea por meio da televisão. Você pode puxar porque é uma coisa que está bem próxima do aluno.” (L., USP)

"Você tem que falar a linguagem dos alunos e, pra isso, você tem que ver o que eles veem." (G., USP)

"Eu sou professor de jovem na escola, então eu mando coisa por e-mail, adiciono eles no Orkut, falo com alguns no MSN, e isso pra eles é uma coisa que contribui demais, porque algumas salas que são consideradas as difíceis na escola eu não tenho problema nenhum para trabalhar. Por quê? Porque eu sou o professor que se comunica com a sala." (B., UNICSUL) 
Como já sinaliza a fala do último entrevistado, a comunicação é apontada pelos futuros professores como elemento-chave da educação, e eles não se restringem a meios de comunicação: em geral referem-se à importância do processo comunicacional. Assim como destacou Penteado, o objetivo da aproximação dos campos da educação e da comunicação vai além de trazer os meios de comunicação para a escola. Essa é uma parte do trabalho, porém busca-se uma maior amplitude, visando a desenvolver a prática escolar como um processo comunicacional. As respostas dos pesquisados refletem um entendimento nessa direção, pois, diante da abrangente pergunta "Na sua opinião, qual a importância da comunicação para a educação?”, a maioria retornou com outra pergunta: “Comunicação em que sentido?”. Não houve, de imediato, uma associação da palavra "comunicação" a "meios de comunicação", ainda que o tema estivesse em pauta na conversa. Ao serem confrontados com a possibilidade de responder de acordo com o que cada um entendesse por comunicação, ficou evidente a noção de comunicação como interação humana e capacidade de expressão.

“A comunicação é fundamental porque é o elo; para educar você precisa da comunicação." (P., UNICSUL)

“A comunicação é fundamental. Às vezes você tem que extrair muito do aluno, conversar muito com ele para saber por que ele está com aquela dificuldade. Então é fundamental haver diálogo.” (D., USP)

“A comunicação é a base, o principal instrumento do professor. Sem a comunicação verbal não vai ter aprendizado. É preciso ter interação entre professor e aluno, discussões em grupo. Tem que motivar o aluno a falar, a falar alto, para todos ouvirem. Não só o professor falar lá na frente. Tem que incentivar a participação.” (M., USP)

“Acho que comunicação é essencial. Como eu tenho 20 anos e dou aula no Ensino Médio (como professor eventual), achei que eles fossem pensar 'nossa, professor novinho, não sabe nada, é molecão de tudo', mas não, eles me veem como adulto, pois eu mantenho um diálogo. Não é aquela coisa de amiguinho, mas eu me comunico com eles. Falo na língua deles, dou exemplo real mesmo. Eu estou ensinando sujeito e falo 
'oh, você vai mandar um scrap (recado) no Orkut, e como é que você faz?'. No Facebook também, essas coisas assim. Então comunicação ajuda muito porque te coloca num patamar mais igualitário com seu aluno, você fica mais perto dele. Professor não fica sendo visto como aquele homem que depois que sai da escola pega sua nave espacial e vai para outro planeta. Eles te encontram na rua e falam 'e aí, professor', ou chamam pelo nome, porque eles sabem que eu tenho uma vida social normal, então isso aproxima.” (B., UNICSUL)

"Definitivamente, acho bem importante. Eu acho que educação é comunicação, troca de informações e acho que deve ter a ver com troca, não é o professor ali falando e as pessoas absorvendo" (J., USP)

Quando a pergunta se referia especificamente ao uso dos meios de comunicação na educação formal, os futuros professores mostraram-se bastante receptivos à presença dessas linguagens em sala de aula:

"Quando eu for professor, eu tenho intenção de usar os meios de comunicação porque, para a criança, ou mesmo para o adolescente, não adianta você ensinar apenas aquilo que está nos livros, é a vida dela que está ao redor nos meios de comunicação, tanto a televisão quanto o rádio, é o que está acontecendo realmente no mundo, então acho importante ensinar isso pra ela." (D., USP)

“TV e internet são a vida deles. Os alunos assistem TV e usam internet o tempo todo. Então se eles entram na sala de aula e veem alguma coisa totalmente diferente, é um choque, daí é bem mais fácil você conversar com eles sobre alguma coisa que eles já conhecem pra trazê-los pra sala de aula, pra alguma coisa que eles vão aprender." (N., USP)

"Eu acho que hoje a escola separa um pouco o que acontece fora e o que tem que ser colocado lá dentro, quando, na verdade, eu acho que tem que pegar essas informações da mídia e trazer para a escola porque é o assunto do dia a dia deles, então eu acho que tinha que ser trabalhado em cima disso." (V., UNICSUL) 
Ficou evidente durante as entrevistas uma disposição dos futuros professores em usar os meios de comunicação em sala de aula. Eles acreditam na importância de trazer essas linguagens para a escola, como uma forma de estabelecer diálogo com o aluno e incentivar a aprendizagem. No entanto, muitos admitiram que não se sentem preparados para trabalhar com outras linguagens, que não saberiam montar uma aula nessa direção porque não tiveram orientação na universidade. Os que se sentem preparados destacam que é decorrência de seu conhecimento experimental:

"Nesse aspecto de trabalhar com outras linguagens eu não me sinto muito preparada, mas eu acho que é interessante.” (C., UNICSUL)

"Acho que eu até poderia dar uma aula com outras linguagens, mas acho que o pouco que eu me sinto preparada não é tanto pela formação daqui, dos professores, mas pela formação que eu tive na escola, da vivência artística que eu tive e porque eu vou muito atrás de muitas coisas, de outras linguagens. Então tive experiência com música, mas por minha conta, nada da escola nem da faculdade. Tive experiência com outras artes, com algumas outras linguagens, me interessei muito pela mídia. Claro que a faculdade me dá um suporte se eu for atrás, mas não existe iniciativa da faculdade. Eu tive pouco sobre isso. (L., USP)

Apesar de todos concordarem sobre a importância de trabalhar os meios de comunicação na escola, quando o assunto se refere especificamente à televisão, identificamos dois posicionamentos distintos: um que reconhece a TV como instância de educação informal, condizente, portanto, com a visão de Maria da Glória Gohn, pois o aprendizado é decorrente de processos cuja intencionalidade não é uma formação específica; e outro que a encara como uma "caixa idiota", não tendo nada de proveitoso à formação, o que representa um dos estereótipos apontados por Orozco. Mesmo entre aqueles que reconhecem o potencial pedagógico da TV, nem todos concordam com a ideia de que qualquer programa pode ser educativo, como discutimos com Guillermo Orozco, Maria da Graça Setton e Marília Franco.

"Eu acho um absurdo ver criança de sete anos assistindo à novela das oito. Eu acho isso muito agressivo, aquela coisa indicada para o pai dele e ele assistindo. Na TV aberta a gente tem a Cultura, existem alguns canais de TV por assinatura que têm uma 
orientação pedagógica, mas a maioria é desenho. Tem algumas coisas construtivas, programas sobre alimentação, mas tem muita coisa ruim, reality shows, não dá." (P., UNICSUL)

“Tem uns programas que dá para levar pra sala de aula para trabalhar com comunicação, com esse tipo de coisa. Agora tem alguns que não dá. Eu levaria uma reportagem de jornal, algum assunto que está sendo falado muito na semana, no mês, dá pra levar. Agora novela não dá, né? Dependendo do assunto que está tratando na novela não dá pra levar.” (R., UNICSUL)

"Acho que o uso dos meios de comunicação depende da matéria. Acho que seria um pouco mais difícil usar programas de TV." (C., USP)

Porém há também quem reconheça a televisão como instância de educação informal e acredite, assim como foi apontado pelos autores, que qualquer programa pode ser educativo, não havendo necessidade de levar para a escola somente atrações preparadas com essa intenção. Segundo Orozco, o contexto de aprendizagem propício para uma intervenção pedagógica deve ter como referente a programação que o estudante aprecia, seja uma telenovela, um programa esportivo, um filme e assim por diante. $\mathrm{O}$ docente não precisa preparar um material específico, pois ele já está pronto: embora tenha sido feito para outros fins, pode ser readaptado ao contexto educativo.

“Acho que a mídia é uma instância educativa, porque ela tem relação com valores. Por exemplo, o canal Futura trabalha muito com educação. Tem canais especializados na TV a cabo e tem também os programas da TV aberta. Vamos falar de Big Brother: está relacionado a valores, então às vezes a atitude de um e de outro você pode trabalhar isso em sala de aula no sentido de mostrar de uma certa forma o que é certo, o que é errado, o que a sociedade aceita, o que não aceita. Eu acho que tudo aquilo que está relacionado com valores e conhecimento é uma forma de educar. Mesmo os programas de TV aberta, que às vezes não têm esse propósito, que são simplesmente entretenimento, mas se você souber buscar alguma coisa dele que possa auxiliar no processo de educação, eu acho que é útil. Agora é aí que está o problema: é saber utilizar, é não falar só por falar. O professor pode tornar útil qualquer conhecimento desde que ele saiba trabalhar e desde que ele esteja disposto" (A., USP) 
"A mídia é uma instância educativa, maior até talvez que a escola. Todas as mídias, televisão, livro, revista, internet. Qualquer vivência que a criança tenha fora da escola é educativa, o tempo todo. Essa entrevista é educativa, eu ter pegado o ônibus da minha casa até aqui eu aprendi alguma coisa, mas a gente pensa no educativo quando ele é instrutivo: tem um programa e você aplica, mas não, educativo é o tempo todo." (L., USP)

"Eu acho que pode usar qualquer programa, até mesmo novelas. Pode levantar uma discussão pra sala a partir de novelas, pelo menos é um assunto que rende. Que nem, estava passando Caminho das Índias, aproveita e dá uma aula sobre a Índia, tenho certeza que os alunos vão se interessar. Eles vão falar que viram aquilo na novela. Eu acho ótimo trazer assuntos da mídia porque aí você traz o interesse do aluno junto." (P., UNICSUL)

"De qualquer programa pode ser feito uso educativo, eu acredito que sim. Você pode fazer debate usando o 'Pânico', novela do Manoel Carlos, novela mexicana, qualquer programa porque tudo isso é conhecimento. As pessoas não são robozinhos, então você pode pegar um discurso e relacionar. O professor de física pode tirar a velocidade média numa corrida. Por que não pegar os exercícios lá? 'Assistam à corrida domingo que a prova vai ser sobre isso'. Se ele já tivesse explicado, olha que legal: o aluno vai ter que assistir à corrida pra entender melhor a prova. Dá pra usar o futebol pra ensinar matemática, geometria, tudo dá para ser transformado em conhecimento, basta uma gota de genialidade e vontade.” (B., UNICSUL)

Como discutimos no quadro teórico de referência, Orozco acredita que os programas da TV comercial podem funcionar como estratégias para extrair e sistematizar o aprendizado obtido pelo estudante das mais diversas fontes e, a partir desse trabalho, a escola pode ajudar a tornar o aluno mais seletivo, sabendo explorar e analisar o programa a que está assistindo. Franco e Setton também concordam que a ideia não é levar o jovem a desligar a televisão, e sim promover uma desconstrução pedagógica que permita um novo olhar. Alguns pesquisados seguem a mesma linha de pensamento que esses autores, ainda que não conheçam seus textos: 
“Todo mundo assiste TV, tem pelo menos duas em casa, por que não assistir TV? No entanto, você tem que assistir com seu olhar crítico. Por que não assistir ao jornal da Globo, da Record e da Band para ver como a mesma notícia é abordada? 'Malhação', outro fenômeno entre eles, você pode fazer uma análise do programa. Quem tem que abrir o olho dos alunos? É o cara mais instruído, que no caso é o professor. Porque ele fez um curso, ele estudou pra aquilo, ele consegue de certa forma canalizar melhor e orientar" (B., UNICSUL)

“A pessoa é quem vai decidir se aquilo é bom para ela ou não. O professor tem que ser aquele mediador, a família também tem que ser mediadora. A criança pode assistir televisão? Pode. Agora, determinados programas é claro que você não deve deixar seus filhos assistirem, mas, mesmo que eles assistam, você deve estar ali, mediando e orientando. O professor também, a mesma coisa. Você vai ser mediador, vai orientar." (C., UNICSUL)

Já num posicionamento distinto, identificamos em algumas falas dos entrevistados o estereótipo apontado por Orozco de que a TV é considerada uma "caixa idiota", que nada tem de proveitoso à formação dos alunos:

“A televisão não acrescenta muita coisa, ela não é uma fonte de conhecimento.” (O., UNICSUL)

“Televisão pode ser educativa ou 'deseducativa', depende do uso que se faz dela” (G., USP)

"Não acho que a televisão possa ser uma instância educativa. Tem muita bobagem, muita coisa ruim, muita influência: 'faz isso porque isso é bom', e às vezes não é bom.” (R., UNICSUL)

“Tem muita porcaria na televisão e às vezes as pessoas só assimilam as porcarias. Porque tem pouco que é bom mesmo e não assimilam. O programa pode influenciar o comportamento de uma forma negativa, talvez você vendo uma novela possa pensar: 'Ah, tal pessoa faz isso então eu posso também fazer', tipo um comportamento negativo. Se está na novela, então eu posso fazer." (C., USP) 
A partir dos relatos, é possível identificar não apenas uma visão depreciativa da televisão, mas também um posicionamento defensivo em relação à mídia, pois alguns entrevistados acreditam que ela exerce plena influência sobre os alunos. As declarações a seguir também ilustram essa percepção:

“Em novela, às vezes você vê muita vingança, muita briga, cenas explícitas de sexo, como se todo mundo devesse fazer aquilo. Você pode estimular comportamentos diferentes. Às vezes a novela pode mostrar a realidade de uma maneira diferente do que ela é, de certa forma fazer com que a realidade fique igual à da novela" (V., USP)

“Tem alguns programas que você vê que eles não vão ser relevantes ou então até prejudiciais, de certa forma. Se é um programa, por exemplo, que incita a violência, só quem pode assistir é quem realmente sabe que violência não é legal, que aquilo é uma brincadeira. Então se você passa isso para uma criança, na minha opinião, você está prejudicando o ensino dela" (D., USP)

"Eu acho que a televisão mostra muito o individual, e não o coletivo. Eu me dou bem, os outros que se danem. Inclusive cenas que mostram o cara que roubou saindo do Brasil e dando uma banana num helicóptero e tudo bem. Sabe, na época do Collor. Então, as coisas passaram a ser 'o que é que tem? Eu faço, e daí? Eu me dou bem, que se dane o resto'. E as pessoas acabam reproduzindo isso, que é o caso do Big Brother. É um bando de gente que não faz nada o dia inteiro, com atos libidinosos, o que as crianças vão aprender com isso? Por que eu vou trabalhar? Por que eu vou ser professora? Eu vou ser artista! Vou ganhar um milhão de reais fazendo sacanagem em público. Agora, e eu como pessoa, e a minha moral, e a minha ética? Não tem. Então a mídia tem esse tipo de responsabilidade, que é a formação de valores sociais." (G., USP)

É possível identificar também uma evidente desconfiança em relação à televisão na fala da mesma pessoa que deu a declaração acima, pois ela aponta o meio como fonte de dominação e manipulação: 
"Eu acho que dá para aprender com a televisão, mas aí precisa ver os interesses por trás da mídia. Será que é interessante tornar a população culta, pensante, não manipulável? Então o problema é esse: a mídia pode ajudar muito, pode, está com a faca e o queijo na mão, mas do jeito que está hoje eu acho muito difícil. Os programas apelam demais à degradação, mesmo as novelas, elas não contribuem pra nada." (G., USP)

As declarações sobre a televisão nos levam a perceber uma contradição no que se refere à produção de sentidos porque, ao mesmo tempo em que o futuro professor compreende o aprendizado do estudante como uma construção, a qual depende do contexto e de elementos mediativos, muitas vezes ele vê a televisão como um meio capaz de provocar impacto direto no receptor e como fonte de manipulação e dominação, concentrando as forças no polo emissor. A questão do jogo, da negociação de sentidos valeria dentro da sala de aula, no trabalho do professor com o aluno. Porém este, quando estivesse sozinho e "desprotegido", cairia facilmente "nas garras" da televisão, reproduzindo os comportamentos ditados pela TV e apresentando atitudes conformistas. Quando se trata da mídia, principalmente da televisão, ainda ocorre um isolamento do papel do emissor, considerando-o como unidade autônoma de significação. Porém, como discutimos com Citelli, o sentido se constrói no âmbito do jogo dialogal, na metáfora da travessia: "Nessa perspectiva não há atracadouros seguros, mas instâncias de passagem do 'entre' - aquele espaço intervalar que permite apreender a natureza dos procedimentos dialógicos e interativos" (CITELLI, 2000: 54). Analisando sob a ótica das mediações de Jesús Martín-Barbero, o discurso dos meios de comunicação é confrontado com uma variedade de signos e linguagens decorrentes das relações culturais e sociais, ficando a compreensão das mensagens atrelada às diferentes mediações. Não há, portanto, sentido predeterminado. Esse entendimento ficou evidente nas falas dos futuros professores quando eles se referiam à aprendizagem na escola, porém, paradoxalmente, o entendimento não foi o mesmo no que se referia à mídia.

Consideramos essa contradição mais um reflexo da tensão discursiva vivida atualmente pelo professor. Ao mesmo tempo em que ele acredita na chamada pedagogia renovada, colocando o aluno como sujeito de seu aprendizado e abrindo espaço para o lúdico, recorre também a formações discursivas "tradicionais", como a que vê os meios de comunicação como "más influências". Portanto, por um lado, os futuros professores superaram o estereótipo de que escola "deve ser coisa séria", abrindo espaço para o 
prazer e para o lúdico, mas, por outro lado, ainda existe o estereótipo de que os alunos são receptores passivos, plenamente influenciados pelos meios de comunicação.

\section{Conflito entre o prescrito e a experiência}

Ainda que nossa intenção não tenha sido verificar as práticas profissionais, pudemos identificar algumas contradições internas no discurso dos futuros professores que revelam o conflito entre a expectativa profissional e a prática. $\mathrm{O}$ depoimento a seguir ilustra essa situação: em um momento, V. (USP) defende uma relação de troca em sala de aula, com professor e aluno aprendendo juntos. Porém, em outro momento, ao contar sobre sua experiência no Ensino Fundamental, revela ter usado métodos coercitivos para "controlar" a turma:

"Acho que deve haver uma relação de troca entre professor e aluno. $\mathrm{O}$ aluno pode aprender com o conhecimento que o professor tem para passar, e o professor também pode aprender com seu aluno, aprender a dar aula e aprender de relacionamentos também. E aprende até mais sobre o assunto que ele se propõe a ensinar.” (V., USP)

"Dar aula no Fundamental foi uma experiência muito bacana porque criança é um público legal para você trabalhar, mas por outro lado é difícil para você controlar elas na sala. Mas elas não são alunos que dormem, que te maltratam, como os adolescentes ou como os adultos. Elas são sempre alegres, vibrantes na sala, querendo contar coisas para você, e era um pouco difícil mandar o pessoal sentar e vamos estudar. [E o que você fazia?] Eu ameaçava os alunos, dizia que ia colocar pra fora, fazia um gráfico de comportamento na sala. Eu dava adesivo de brinde para quem colaborava.” (V., USP)

Contradição parecida pode ser identificada também nos relatos abaixo, pois D. (USP) inicialmente defende um ensino individualizado, que leve em consideração as necessidades de cada aluno e use o diálogo para superar as dificuldades, porém, depois, afirma que coloca para fora da sala quem não estiver interessado:

“A relação entre professor e aluno tem que ser a melhor possível, sempre com diálogo. Você tem que conversar com o aluno, tratar ele como individual. Lógico que tem coisas que você tem que fazer pra sala inteira, mas se você perguntar pro aluno como seria o individual, você vai ver que cada um tem o seu modo de aprender, então 
eu espero conseguir isso conversando com eles, vendo quais são as dificuldades de cada um.” (D., USP)

“Aquele aluno que não está interessado e começa a tirar o interesse dos outros, eu vou tentar mais ainda puxar ele pra matéria, mas se eu vejo que mesmo assim ele não tem interesse, eu vou colocar para fora da sala de aula. Porque eu vejo que isso funcionava muito com um professor que eu tinha no Ensino Médio: todo mundo prestava atenção na aula dele. Porque quem não prestava atenção, ele não deixava dispersar os outros. Ele ia lá e tirava da sala de aula.” (D., USP)

As palavras desses dois entrevistados evidenciam a tensão vivida pelo professor: ele acredita numa pedagogia que prime pelo diálogo e coloque educador e educando como sujeitos cognoscentes, no entanto, ao chegar à sala de aula, encontra situações com as quais não consegue lidar e acaba recorrendo a métodos coercitivos, porque, como destacou Perrenoud, ele não foi preparado para enfrentar o dia a dia da profissão. Para o autor, como os cursos de formação inicial não abordam a amplitude dos dilemas enfrentados em sala de aula, ocorrem inúmeras desilusões, já que existe uma defasagem entre o prescrito e a realidade da profissão. Pudemos perceber que os entrevistados sentem esse choque já no momento do estágio:

"Achei importante fazer o estágio para ver o que acontece de fato na escola porque às vezes a gente tem uma visão na universidade e, quando chega na escola, a gente tem uma outra realidade. Pelo menos na região onde a gente vive aqui, uma região mais carente, a gente tem muito a questão social que atrapalha a aprendizagem da criança, como pais separados, pais que brigam dentro de casa o tempo todo, violência doméstica, casos de abuso sexual dentro de casa. Há casos de criança que mata pai, mata pai, que hoje tem onde dormir, amanhã não. São fatores que contribuem muito para a dificuldade da aprendizagem, e a gente precisa de professores melhor preparados pra isso." (V., UNICSUL)

"A classe onde fiz estágio era uma loucura, as crianças berrando, se batendo. A professora mandava ficar quieto, fazer a lição, mas não adiantava.” (C., USP) 
"No estágio eu aprendi coisas que eu quero fazer e muitas coisas que eu não quero fazer com meus alunos. Por exemplo, no pré a professora pintou o desenho de uma abelha, várias palavras com a letra A e colocou desenhos na lousa para que eles fizessem, só que ela denominou as cores que os alunos tinham que pintar. Então cadê a autonomia do aluno de pintar a abelha dele da cor que ele quer? Não, tinha que ser da cor que ela queria e veio um aluno mostrar pra ela e ela: "não é pra pintar essa asa de verde, a asa é azul'. Isso pra mim foi bem complicado. E também no fundamental algumas atitudes do tipo: a professora escreveu um texto na lousa, dividiu umas partes da lousa, e tem aqueles alunos que têm mais dificuldade para escrever. Cada um ia lendo uma frase, aí chegava naquele que ela sabia que não tinha um bom desenvolvimento, não estava à altura que ela julgava certo que a sala deveria acompanhar, ela dizia 'você não, você ainda nem copiou, você não'. E pulava. Ou seja, ela discriminava aquele aluno que não tinha terminado. Eu me sentia discriminada, parecia que era comigo. E aquilo é uma punição, você desestimula o aluno. E eu ouvi de um aluno da sala dela uma coisa que eu quase chorei. Eu perguntei pra ele 'Jorge, você não terminou a lição por quê?'. 'Ah, professora, eu sou burro, eu nunca termino'. Então ela não tem a motivação. A criança ainda não tem uma autonomia formada para ter noção de que ela pode correr atrás do desenvolvimento, da aprendizagem dela. Então professor que acaba rotulando o aluno, ele dá uma sentença pro aluno.” (P., UNICSUL)

"Dou aula na educação infantil, mas estou em crise total. Faz dois meses que estou trabalhando, mas... Apesar de a coordenadora dizer umas coisas que eu acho bem boas, na hora que eu vejo a professora na prática, eu falo 'socorro'. Hoje, por exemplo, a gente estava numa sala que é toda construída de espuma para as crianças explorarem, e a primeira coisa é 'Todo mundo senta no chão e espera sua vez para poder brincar'. Agora imagine: dezesseis crianças sentadas olhando para uma coisa supercolorida e superdivertida tendo que esperar sua vez. Aí obviamente algumas começam a surtar, aí a professora diz assim: "Você não pode brincar até ficar quieto e parar de chorar. O professor não vai chamar você pra brincar se você não estiver sentado encostado com as costas na parede'. Eu olho e não sei nem por onde começar a dizer tudo o que está errado. O discurso é um, e a prática é outra.” (J., USP) 
Apesar do desapontamento vivido no estágio, a grande maioria dos futuros professores acredita que pode fazer diferente, ou pelo menos tentar. Somente uma das pessoas entrevistadas fez questão de ressaltar que não tem expectativas nesse sentido:

"Acho que vou acabar dando aula no Estado, de português. Sem idealismo nenhum. 'Ah porque eu quero mudar o país, tal', não, estou indo por trabalho mesmo, como qualquer outro. Quero uma segurança.” (M., USP)

Os outros entrevistados em geral mostraram-se dispostos a fazer do trabalho docente um meio de transformação e muitos inclusive criticaram posturas reativas de professores com quem já conviveram:

"Tem professor que parece que abandonou o barco. Eu entendo que cada um tem sua particularidade, mas, a partir do momento que eu quero seguir aquela profissão, eu vou encontrar contratempos, só que eu, enquanto profissional desmotivada, eu não estou só me prejudicando, eu tenho aquele número de alunos que eu vou prejudicar." (P., UNISUL)

“Os professores reclamam o tempo todo, parece que estão lá com arma na cabeça, que alguém está apontando uma arma na cabeça deles, mas na verdade não estão. Já ouvi de um professor aqui na universidade que o pior lugar para fazer estágio é a sala dos professores. Se a pessoa está insatisfeita, por que continua? A desmotivação é constante, eles reclamam muito. Por quê? Quando um médico se vê frente a uma doença que ele nunca tinha visto antes, que ele não entende, ele vai lá e pesquisa, vai a fundo, tenta aprender o máximo sobre o assunto. O professor diante de um aluno problema, diante de uma classe problema vira as costas, acha que o aluno que não quer aprender, que o aluno é isso, o aluno é aquilo e não tem o menor interesse em saber o que está realmente acontecendo e parar para pensar, refletir que o problema pode ser o professor e não o aluno." (J., UNICSUL)

"Tem professores que se acomodam e dão somente aquilo que o Estado pede, o que ele oferece e, se não funcionar, fica por isso mesmo. Nessa escola que eu fui, tinha professores que eram superempenhados e tinha professores que não. Então é fácil colocar a culpa só no Estado - ah, o Estado não faz isso e aquilo - mas depende muito 
do professor e da formação que o professor teve, se o professor é engajado no que faz." (A., USP)

"Pra mim o argumento de que o professor é sobrecarregado não convence. Professor tem o direito de pegar quantas aulas ele quiser, desde que ele não deixe nenhuma turma na mão. Dinheiro todo mundo quer, ninguém trabalha por hobby, as pessoas precisam de dinheiro, no entanto eu vou pegar mais compromissos do que eu consigo fazer? Alguns professores não têm a profissão como profissão, e ser professor é essencialmente uma profissão. Você ganha dinheiro com isso, mas alguns professores acham que eles estão fazendo um favor pra sociedade, e não estão, estão sendo pagos para aquilo. Acho que essa desculpa é normal, conveniente para aqueles que usam, mas acho totalmente incoerente profissionalmente. Não é profissional, não é ético. Se você quer dar uma aula mais ou menos, nem pegue, deixa alguém pegar, uma pessoa que vá dar aula de fato. Porque você não está destruindo a 'sétima E', você está destruindo cada indivíduo da 'sétima E', que lá na frente vai ser 'terceiro F', que não quer saber de nada mais porque os professores deles nunca deram atenção. Triste.” (B., UNICSUL)

Durante as entrevistas, ficou evidente a disposição dos futuros professores em não reproduzir comportamentos que desaprovam na profissão. Há um reconhecimento da autonomia e da responsabilidade do professor, o que é essencial, como apontou Perrenoud, para chegar ao modelo de escola que desejamos, ou seja, uma escola que não apenas transmita conhecimento, mas que dê condições ao sujeito de articular o que aprende dentro e fora da instituição formal, partindo de bases reflexivas e em conexão com a condição comunicativa contemporânea. No entanto, esse percurso está sujeito à tensão entre as formações discursivas, pois, embora os futuros professores adotem a formação discursiva do diálogo, da liberdade, do engajamento do professor, ela pode ser "contaminada" por outras formações discursivas, já que não é fixa em seus limites. Por isso, em algumas situações, os entrevistados recorrem ao discurso "tradicional" da escola, com os preceitos de ordem, disciplina e autoridade.

\section{Tecnologia}

A análise descritiva a partir dos questionários nos indicou que os futuros professores estão conectados, tendo uma relação de proximidade com o computador e a internet. As entrevistas complementam esses resultados e mostram que alguns 
participantes da pesquisa já levam essas experiências às escolas onde atuam como professores eventuais e consideram importante relacionar as aulas à tecnologia.

"Eu sou o professor que, em vez de passar aquele texto enorme na sala, que perde horas passando aquele texto, pega e manda antes por e-mail e depois só comenta o texto na sala. A primeira vez que fiz isso os alunos ficaram impressionados. Eu perguntei: ‘Alguém tem e-mail da classe?'. E eles perguntaram 'Como assim, professor?'. E eu disse: 'Façam e-mail, assim quando a gente tiver um texto muito grande eu mando por e-mail, vocês dão uma olhada, aproveitam a hora que estiverem na lan house'. E eles ficaram assim 'Nossa!'. Porque até eles, que são jovens, têm um pouco de receio quanto a isso porque nenhum outro professor faz, não é muito comum na postura do professor, mas isso auxilia bastante, inclusive eu não tenho problema com aluno nenhum. Todos eles falam comigo, todos me respeitam.” (B., UNICSUL)

"Eu acho muito importante usar a internet em sala de aula porque é fundamental para você fazer o aluno interagir com a matéria, ter mais atenção com a matéria porque às vezes ele fica na internet horas. Que nem minha irmã, ela fica horas e horas na internet depois que volta da escola. Então é uma forma de você fazer o aluno pegar interessa na matéria, ter mesmo uma forma de aprendizado diferente. Você fazer, por exemplo, ele procurar no Youtube (site de vídeos) as entrevistas da Clarice Lispector, usar aquilo com o autor que estou trabalhando. É uma forma diferente de ele aprender e interagir com os outros alunos, divulgar o trabalho dele por uma comunidade do Orkut, melhorar a interação entre os alunos e a interação entre aluno-professor, e alunomatéria.” (D., USP)

"Eu tenho Orkut e passo pra eles quando me pedem, eu não fico com medo. Eu não deixo ter intimidade, mas proximidade é legal, é importante, e eu acho que eles me respeitam mais por isso do que aqueles professores que são intocáveis, arrogantes." (N., UNICSUL)

Um dos entrevistados inclusive ressalta que, mesmo tendo familiaridade com recursos tecnológicos, também aprende com seus alunos, pois eles conhecem todas as novidades da internet e existe uma relação de troca em sala de aula, existe comunicação: 
"Eu aprendo muito com eles. Twitter (microblog em que as pessoas trocam mensagens curtas), essas coisas novas que às vezes a gente nem tem tempo pra ficar navegando, eu falo 'Ah, você tem Twitter? Como funciona?'. E eles explicam 'Ah, faz assim, tal', e vão ensinando. Quando ele falam do 'Zé Moleza' (site que oferece trabalhos escolares), eu digo que não é para ficar olhando o 'Zé Moleza' e ensino a usar o meio de comunicação. O Google, por exemplo, é um site de pesquisa, só que você tem que saber filtrar todas as informações que vai encontrar lá. Muitas coisas vão estar coerentes e outras não. Aí eu vou dando dicas, 'você pesquisa assim, tal site é legal, não confia muito no Wikipedia (enciclopédia construída pelo público), vai procurar em outras fontes, dá uma olhadinha nos autores', e levo tranquilamente assim. E aprendo, é uma troca. Eles me ensinam, eu ensino, e assim a gente vai trocando conhecimento, construindo. Existe um diálogo graças à comunicação.” (B., UNICSUL)

A partir dos relatos que apresentamos, fica evidente que os próprios pesquisados se interessam pelas inovações tecnológicas e que perceberam, no contato com os estudantes, que essas linguagens podem contribuir com o trabalho do professor. Esses três entrevistados, que já atuam como docentes eventuais, fazem uso da tecnologia como um meio de interação com o aluno e de mediação do aprendizado:

“A tecnologia pode ser um mediador na relação com o aluno porque se você é um professor tecnológico, os alunos vão se identificar. Mesmo aquele professor que não está há muito tempo na rede, se ele mostrar que conhece um pouco de tecnologia, os alunos vão perceber que ele não é tão quadrado assim. Então ela pode ser mediadora porque você vai estar se aproximando do aluno porque está usando os mesmos meios." (B., UNICSUL)

O depoimento anterior condiz com a proposta de Maria da Graça Setton: a aproximação com o discurso que envolve o jovem é uma forma de melhorar a relação entre educandos e educadores. No entanto, a maior parte do grupo pesquisado tem uma visão instrumental das tecnologias da informação e da comunicação, encarando-as como suportes, como recursos didáticos.

"Eu gosto muito de trabalhar com vídeo, de trabalhar com imagem, então eu acho que a comunicação na verdade é uma ferramenta a mais. Tudo aquilo que pode auxiliar 
o professor como uma ferramenta a mais é válido. Internet pode auxiliar, sou a favor da internet desde que seja utilizada de uma forma coerente, uma forma interessante. Uso de mídias, de comunicação, de vídeos, de imagem, tudo isso pode auxiliar, mas tem que ser num momento certo, entendeu? Você passa a teoria e depois busca alguma atividade, alguma ferramenta, como imagem, vídeo, alguma ferramenta a mais para fechar." (A., USP)

"Acho que a aula depende dos recursos que a gente vai ter em mãos. A disponibilidade do instrumento. Se eu tiver o recurso, vou usar, mas eu acho que a tecnologia não tem o que contribuir muito, você tem que se adequar para poder usar um negócio que é inevitável, então contribuir no sentido de que vai me formar, ou vai me ajudar a formar, eu acho que não. Eu acho que você tem que usar porque a linguagem do ensino mudou no sentido da tecnologia, ela alcança de uma forma mais eficaz, mais direta do que uma aula tradicional, então ou você se adequa a isso ou com o tempo você não vai existir mais.” (R., UNICSUL)

"Acho superimportante a tecnologia, acho que tem que ter computador, projetor, tem que ter recursos, mas a escola pública está aquém disso. A sala de informática tem poucos computadores, as salas ficam trancadas por questão de roubo, então está distante do ideal." (M., USP)

"O que eu percebo é que a tecnologia é muito falada, mas dentro da sala de aula ela não é muito utilizada. Eu posso estar errada, mas entendo que a tecnologia é internet, televisão, são equipamentos mesmo que têm a contribuir, então nem sempre na escola há esses recursos. Tem escola que eu fui que tem laboratório de informática, mas não é utilizado porque não tem computadores suficientes para todos, então o professor acaba nem indo. Acho que a gente precisa de recursos pra trazer toda essa tecnologia pra sala de aula." (P., UNICSUL)

A tecnologia é vista como instrumento, e não como mediadora da sociedade, como discutimos com Martín-Barbero. Em diversos momentos, pudemos notar que o futuro professor acredita que "tem que usar" os recursos tecnológicos e os meios de comunicação, como resultado de uma imposição da sociedade da informação, e não como elementos mediadores na construção de sentido. A tecnologia, como apontou José 
Joaquín Brunner, é vista como um elemento alheio à educação, "um fator externo que deve ser 'trazido' para a escola e que, nessas circunstâncias, é pensado de modo puramente instrumental, como uma caixa de ferramentas que se toma emprestada para pô-la a serviço de uma missão humana transcedental" (BRUNNER, 2004: 19). E a própria universidade muitas vezes reproduz essa visão instrumental em suas práticas de ensino. Foi o que pudemos perceber a partir dos depoimentos sobre as aulas online da UNICSUL. A universidade oferece $20 \%$ das aulas a distância e, para isso, conta com uma plataforma interativa chamada "Blackboard", onde os professores podem disponibilizar materiais e promover discussões em fóruns com a participação dos alunos. Os estudantes pesquisados têm, todo mês, uma semana de aulas online, ou seja, todas as disciplinas são ministradas virtualmente durante a chamada "semana online", em que os alunos não precisam estar presentes na universidade, pois realizam atividades de casa, pelo computador. Esse formato não é mais adotado pela UNICSUL para as turmas mais recentes, pois a universidade deixou de promover a "semana online" para instituir uma disciplina totalmente online por semestre. No entanto, as turmas que estão no final do curso, como é o caso de nossos entrevistados, continuam no formato anterior, tendo, portanto, parte de cada uma das disciplinas da grade curricular oferecida virtualmente. A iniciativa divide os alunos e, segundo um dos entrevistados, foi motivo de protesto no ano em que foi implantada, 2007:

"Eu fui a primeira turma a ter aula online, os cobaias da turma, muita gente ficou revoltadíssima, teve rebelião na UNICSUL, queimaram lata de lixo, tudo porque haveria aula online. Mas isso é o futuro da humanidade! Hoje você fala com alguém no Japão pela webcam. Então não tem essa: esse é o futuro. E eu sempre fui a favor, sempre gostei das aulas online por vários motivos. Um, para a inclusão digital: tem muita gente, parece mentira, mas no último ano que não consegue manusear muito bem o computador, o que é fundamental para qualquer área. $\mathrm{O}$ professor vai usar o mimeógrafo até quando? Eu acho importante essa aula online por causa da inclusão digital, porque as pessoas vão ter que correr atrás. Isso de certa forma força as pessoas porque a relação da idade é importante - pode ser que uma pessoa mais velha não goste do computador, mas não é uma questão de gosto, é uma questão de necessidade. Ela pode não gostar mas o aluno dela gosta. Ela está dando pra quem, pra ela? Não, né! Acho que você tem que suprir a necessidade do seu aluno, acho isso muito importante. (B., UNICSUL) 
O argumento de "forçar" o universitário a usar o computador e a internet foi adotado pelos entrevistados que defenderam a atividade:

"Eu aproveitei bastante porque a gente na minha idade não convivia tanto com o computador, não tinha muito interesse, mas aí acabei interagindo mais com o computador, aproveitando melhor. Resolvi comprar um computador, colocar internet na minha casa porque todo mundo falava, mas pra mim não fazia parte da minha vida. E aí comecei a usar e hoje faz parte da minha vida, não faço nada sem ele.” (V., UNICSUL)

"Num primeiro momento eu não gostava. Eu sempre queria as aulas presenciais por conta do contato humano, mas devido a uma correria que é a vida moderna, a vida tecnológica, eu acho que é uma ferramenta necessária. Porque como eu sou da era da transição entre o ensino tradicional para o tecnológico, eu tinha uma certa resistência a informações vindas pelo computador, mas hoje em dia eu acredito que é fundamental pro meio em que a gente vive." (J., UNICSUL)

Já os que se posicionaram contra o ensino a distância na UNICSUL alegaram que não existe um planejamento adequado dessas aulas e, consequentemente, não há um bom aproveitamento, transformando a atividade numa forma de cumprir o calendário:

"Eu não sou a favor da aula online. Desde o início do curso eu nunca fui a favor da aula online. Mesmo porque a aula online não é tomada como muito... O professor lança lá uma atividade, quando lança. Tem professor que lança atividade, tem professor que não lança atividade ou lança depois. Então eu não sou a favor. Eu acho que é um tapa-buraco. Não é uma coisa muito certa, não.” (C., UNICSUL)

“É bem paradão. Até achei que fosse mais interessante, mas o professor só vai lá, coloca texto, pede algum trabalho. A atividade online é muito chata e acaba valendo nota." (T., UNICSUL)

A portaria de número 4.059 do MEC (Ministério da Educação), publicada no Diário Oficial da União em 13 de dezembro de 2004, autoriza as instituições de ensino superior a introduzir, na organização pedagógica e curricular de seus cursos superiores 
reconhecidos, disciplinas que utilizem a modalidade semipresencial. Segundo o documento, "caracteriza-se a modalidade semipresencial como quaisquer atividades didáticas, módulos ou unidades de ensino-aprendizagem centrados na autoaprendizagem e com a mediação de recursos didáticos organizados em diferentes suportes de informação que utilizem tecnologias de comunicação remota" ${ }^{14}$. A portaria prevê que deve haver encontros presenciais e atividades de tutoria, e que a oferta de disciplinas dessa categoria não pode ultrapassar $20 \%$ da carga horária total do curso. Ao introduzir a "semana online", a UNICSUL cumpre os requisitos básicos para aderir à modalidade, que é opcional, ou seja, a universidade decide se deseja oferecer disciplinas semipresenciais. No entanto, pelo relato dos alunos, percebemos que ainda há dificuldade em cumprir um dos artigos da portaria, que prevê "incluir métodos e práticas de ensino-aprendizagem que incorporem o uso integrado de tecnologias de informação e comunicação para a realização dos objetivos pedagógicos" "15. A plataforma interativa adotada pela UNICSUL acaba apenas reproduzindo métodos tradicionais. Por exemplo, em vez de xerocar parte de um texto, o aluno baixa pelo computador, não havendo um planejamento integrado da universidade para a realização dos objetivos pedagógicos a partir das tecnologias da informação e comunicação. Ocorre, portanto, um uso instrumental, identificado mesmo por aqueles que defendem a introdução de atividades online:

"Na verdade, falta uma certa adaptação por parte dos professores. Essa é uma crítica mesmo porque é aula online, mas fica tudo muito solto. O professor coloca o texto lá somente. É um suporte onde o professor pega, coloca o texto, coloca uma atividade e você tem que trazer na próxima aula presencial ou comentar na sala de aula. O que eu acho legal é que no primeiro ano a gente teve uma professora que passava quiz, era bem divertido. Você fazia na internet, tinha tempo pra responder, era um desafio muito legal. Acho que tem que ser pensado nesse sentido. Não é só colocar texto lá.” (B., UNICSUL)

O desenvolvimento de uma atividade semipresencial adequada fica sujeito à ação individual de cada professor. E, mais uma vez, voltamos à questão da formação, pois, se

\footnotetext{
${ }^{14}$ Arquivo completo disponível em http://portal.mec.gov.br/sesu/arquivos/pdf/nova/acs_portaria4059.pdf (vide Anexo)

${ }^{15}$ Idem.
} 
a universidade impõe que todos os professores ofereçam parte de sua disciplina a distância, deveria haver uma capacitação específica e um planejamento integrado, para que de fato a plataforma interativa funcionasse como um mediador do aprendizado. Não pretendemos entrar no mérito da formação dos professores universitários, pois estaríamos fugindo de nosso objetivo, mas é inevitável refletirmos sobre como esse ciclo de imposições se repete: assim como é requisitado do professor do ensino fundamental e médio que trabalhe com outras linguagens sem que, para isso, ele tenha recebido uma formação na universidade, o próprio professor universitário enfrenta situação parecida ao ter que oferecer uma disciplina online. E ainda existe um paradoxo nesse cenário: ao mesmo tempo em que a atividade online exige uma preparação e readaptação do professor universitário, a remuneração é menor exatamente por se tratar de aula online, constatação obtida em conversas informais com professores. O resultado é a reprodução dos métodos tradicionais, apenas usando um novo suporte.

A visão instrumental da tecnologia faz com que os futuros professores acabem perpetuando um dos reducionismos apontados por Orozco: o entendimento do mediático e do informático como simples recursos didáticos, ficando a abordagem em sala de aula atrelada somente à disponibilidade do equipamento. No entanto, na contramão desse discurso, o depoimento de uma pessoa em particular nos chamou a atenção. Ela acredita que a escola não deve se limitar à linguagem oral ou escrita e defende o uso de outras linguagens, porém enfatiza que isso não significa dotar a sala de aula de recursos tecnológicos:

"Essa coisa da linguagem não tem necessariamente a ver com o uso da tecnologia. Porque o que eu acho: as pessoas saem de um modelo completamente rígido, que é o professor lá na frente, com cartilha, todo mundo quieto, não pode dar um pio, não pode ir ao banheiro, não pode mascar chiclete, não pode pôr boné, e só o professor fala e ele que detém todo o conhecimento, ele que manda, para um outro modelo rígido que é assim: ah, se a aula não tiver um bilhão de pirotecnias aquilo não funciona. Parece que as novas tecnologias vão revolucionar a pedagogia. Tem gente que há 30 anos, como Paulo Freire, como outras pessoas, já falavam de possibilidades pedagógicas muito avanças e diferentes, e nada tradicionais. Isso não é de agora. Não é o computador, não é a internet que faz a pedagogia ser super-revolucionária. Tem autores que falavam isso há 30 anos, que já tiravam o professor do centro do universo e já desfaziam a dinâmica da sala de aula quadrada, com as carteiras de determinada forma, então não é a internet. 
A internet revoluciona a pedagogia tanto quanto ela revoluciona o jornalismo, a medicina, a arquitetura. Não é a pedagogia, o ensino, só isso que é revolucionário pela internet. A internet revoluciona a vida de todo mundo. Agora, há 30 anos, quando não tinha internet pra todo mundo, era uma coisa só militar lá, como que esses caras revolucionaram o ensino? Não dá para desconsiderar isso, ninguém está inventando a roda agora, acho que só ajuda." (O., USP)

A fala condiz com nossa intenção de afastar a ideia de um determinismo tecnológico. Como lembrou Soares, as tecnologias não são as salvadoras da educação: "O ambiente mediado por tecnologias pode ajudar a produzir sentidos, convertendo-se em mediação" (SOARES, 2002: 20). Não é a tecnologia que provoca a aprendizagem, e sim o sentido construído a partir daquela mediação. A pessoa entrevistada vê as outras linguagens como uma forma de aproximar professor e aluno, mas isso não está necessariamente relacionado à presença das novas tecnologias na sala de aula. A questão é diminuir na escola a distância entre o discurso didático-pedagógico e as linguagens institucionalmente não-escolares, as quais representam, como vimos com Citelli, "uma pluralidade de signos e códigos que podem abranger desde anúncios publicitários, canções de sucesso, programas televisivos, até videogames e navegação pela Internet" (CITELLI, 2000: 22). O objetivo, como bem apontou O. (USP), não é colocar "um bilhão de pirotecnias" na aula, como se isso fosse imprescindível para o professor ser ouvido, mas sim se aproximar do discurso que envolve o aluno. Porém, em tempos de sociedade da informação e comunicação, certamente esse discurso está atrelado à linguagem das novas tecnologias e dos meios de comunicação, pois, como lembrou Setton, o jovem em processo de escolarização pertence a uma geração que desde cedo se socializou com a cultura midiática.

A reflexão de O. (USP) não apenas supera a visão instrumental das tecnologias, como vai além, identificando o que Orozco chamou de condição comunicativa contemporânea - o trânsito do receptor ao receptor-emissor:

"Eu acho que a comunicação é tão extraordinária hoje, em possibilidades, que já não é mais só uma coisa de a TV ou a internet influenciarem as pessoas. A internet possibilitou uma coisa que é incrível, que não é um grupo de empresários que constrói um discurso e você senta na frente da televisão e ouve aquilo passivamente. Hoje você pode fazer um blog na internet, um jornal de bairro, são as pessoas que estão 
construindo aquele conteúdo. As pessoas estão formando esses meios de comunicação, para o bem e para o mal, elas estão formando esses meios de comunicação. Claro que há uma imensa quantidade de bobagem na internet, afinal não tem muito critério, é um lugar que cabe de tudo. Mas acho que isso é mais positivo do que negativo. Hoje em dia a pessoa faz um filme no celular, na camerazinha, ela está produzindo aquilo também, ela está ajudando essa rede imensa a ser construída.” (O., USP)

Com a convergência tecnológica, a interação deixa de ser apenas simbólica, possibilitando que as audiências sejam criadoras de seus próprios referentes, e não somente ressignificadoras dos referentes transmitidos pelos meios. O receptor torna-se também produtor: “... la interactividad que permiten las nuevas pantallas transciende la mera interacción simbólica con ellas, para situar a las audiencias, en tanto que se cumplan otras condiciones de accesibilidad y cultura digital, como posibles creadoras de sus proprios referentes" (OROZCO, 2009: 3). No entanto, para ajudar o aluno a alcançar esse patamar, é importante que a escola deixe de ver a tecnologia apenas como suporte e ofereça condições para uma produção comunicativa mediada pela tecnologia, o que exige, necessariamente, a formação dos professores para esse trabalho.

\section{Considerações sobre a análise interpretativa}

A partir dos depoimentos dos entrevistados, articulados à perspectiva teórica que estamos seguindo, podemos extrair algumas categorias analíticas para sistematizar a interpretação dos dados. Lembramos que nossa intenção não é generalizar resultados, pois desenvolvemos pesquisa não-probabilística, no entanto podemos identificar algumas categorias que se repetem nos discursos dos futuros professores.

“A inter-relação comunicação/educação está à margem da formação docente" - A universidade começa a abordar a utilização dos meios de comunicação na escola de forma sistematizada, porém ainda circunscrita à grade curricular opcional de alguns cursos. Não há uma efetiva preparação do futuro professor para trabalhar com as linguagens dos meios de comunicação e das novas tecnologias em sala de aula.

"Futuro professor sente necessidade de uma formação mais voltada à prática docente" - Os estudantes pesquisados valorizam o conhecimento teórico, acham fundamental ler e discutir sobre o campo da Educação, porém gostariam de aprender mais sobre como articular esse conhecimento à prática docente. Não se trata de receber 
uma fórmula sobre como dar aula, mas sim de estar preparado para trabalhar diferentes linguagens e lidar com o dia a dia da profissão.

“A produção de sentidos é construída em sala de aula" - Os futuros professores encaram o aprendizado na escola como uma construção que envolve uma série de mediações, inclusive a relação professor-aluno e os conhecimentos adquiridos fora do espaço escolar. Por isso, defendem um ensino dialógico e contextualizado, que leve em consideração as vivências do aluno. Não há uma visão homogênea sobre a recepção em sala de aula, mas sim de sentido construído a partir de interações.

"Os meios de comunicação devem ser trazidos para a escola" - Há um consenso sobre a importância de trabalhar com os meios em sala de aula, pois fazem parte do dia a dia do aluno. O futuro docente acredita que o professor não deve se restringir à linguagem oral e escrita, porque, para o sucesso do processo educativo, é preciso se aproximar da linguagem do jovem, fortemente marcada por experiências com os meios audiovisuais. Dessa forma, é possível estabelecer um diálogo com o estudante e criar condições para desenvolver um novo olhar sobre os processos que envolvem a mídia.

"Superação de estereótipos" - A nova geração docente chega à sala de aula sem reproduzir alguns estereótipos citados por Orozco que costumam dificultar a integração entre comunicação e educação. Os futuros professores acreditam que a escola não é a única instituição legítima para educar, pois existem outros agentes educadores na sociedade e a aprendizagem ocorre o tempo todo. Muitos inclusive apontam a mídia como instância educativa e reconhecem que é possível fazer uso pedagógico de qualquer produto midiático. Além disso, veem a escola como um espaço cruzado por diferentes signos e linguagens, os quais não devem ser ignorados, pelo contrário, devem ser trazidos para a aula de forma a torná-la mais interessante e produtiva. Há, portanto, intenção de recorrer ao lúdico.

“Televisão não contribui com a formação dos alunos" - Apesar de defenderem o trabalho com os meios de comunicação na escola, os entrevistados muitas vezes encaram com desconfiança o conteúdo veiculado pela televisão, suspeitando que ela pode exercer plena influência sobre os alunos. Parte do grupo, embora acredite na construção de sentidos em sala de aula, concentra a atenção no polo emissor quando se trata da TV. O meio é visto como fonte de entretenimento de baixa qualidade e de manipulação, pensamento típico da indústria cultural de Adorno. Para o pensador frankfurtiano, os meios de comunicação só oferecem informações fúteis ao receptor/ consumidor, impedindo a reflexão e reproduzindo padrões de comportamento 
“desavergonhadamente conformistas". As ideias inculcadas pela indústria cultural são sempre as do status-quo, sendo aceitas sem análise nem objeção. "O imperativo categórico da indústria cultural (...) nada tem em comum com a liberdade. (...) Através da ideologia da indústria cultural, o conformismo substitui a consciência: jamais a ordem por ela transmitida é confrontada com o que ela pretende ser ou com os reais interesses dos homens" (ADORNO, 1989: 16). Essa ideia, no entanto, não condiz com o que temos discutido ao longo do trabalho: o sentido se constrói no jogo entre emissor e receptor, é negociado, não havendo, portanto, impacto direto no receptor. A compreensão das mensagens depende de elementos mediativos. Ainda que, em alguns casos, a TV tenha sido considerada instância educativa, na maioria dos relatos ela foi apontada como meio que não contribui para a formação dos alunos.

“Tensão discursiva vivida pelo professor" - Mesmo antes de concluírem a graduação, os entrevistados já evidenciam a tensão discursiva existente na profissão. Ao mesmo tempo em que acreditam na chamada pedagogia renovada, cujo expoente é Paulo Freire, reproduzem discursos coercitivos quando se referem à atuação em sala de aula. Como todos fazem estágio e muitos já atuam como professores eventuais, eles vivenciam o conflito entre a expectativa profissional e a prática docente. Os pesquisados defendem um ensino dialógico, em que o aluno tenha voz e o professor seja o facilitador da aprendizagem, contribuindo para atender às necessidades dos indivíduos. No entanto, ao chegarem à sala de aula, muitas vezes ocorre desilusão por presenciarem um ensino baseado no autoritarismo e na repetição. Ou, no caso dos que atuam como professores eventuais, ao enfrentarem dilemas como desinteresse, falta de educação e agressividade, acabam recorrendo a métodos tradicionais de coerção e exclusão, como ameaças de reprovação e expulsão da sala.

“Tecnologia como instrumento" - Há uma visão instrumental das tecnologias da informação e comunicação, encarando-as como suportes, como recursos didáticos, e não como mediadoras da sociedade. Os futuros professores veem a tecnologia como um elemento externo que deve ser trazido à escola, reduzindo-a ao âmbito mecânico. Consequentemente, a abordagem em sala de aula fica atrelada à disponibilidade do equipamento e não alcança o patamar da produção comunicativa. 


\section{Teste das hipóteses}

A interpretação dos dados nos permitiu testar as hipóteses inicialmente levantadas, de forma a verificar se elas foram confirmadas ou rejeitadas, total ou parcialmente. Consideramos confirmadas as seguintes hipóteses:

- O futuro professor não recebe, ou recebe de forma periférica, uma formação voltada para trabalhar a inter-relação comunicação/educação em sala de aula. Somente os cursos de Pedagogia da USP e da UNICSUL apresentaram disciplinas voltadas ao estudo da comunicação na educação e, ainda assim, como parte da grade curricular optativa. Além disso, no caso da UNICSUL, a disciplina não atendeu à expectativa dos alunos, que esperavam aprender sobre como utilizar as tecnologias da informação e comunicação em suas aulas. Pudemos perceber que as universidades "falam" sobre os meios de comunicação, sobre o contexto tecnológico em que a criança e o jovem estão inseridos, porém não há uma sistematização do tema de forma a preparar o futuro professor para trabalhar com essas linguagens durante a prática docente. A disciplina “Comunicação, Educação e Multimídia”, do curso de Pedagogia da USP, atende plenamente à proposta, reunindo reflexão sobre os meios e orientação sobre como utilizá-los. Porém essa formação é periférica, pois consta da grade optativa. Já no caso dos cursos de Letras, não encontramos nenhuma disciplina voltada à inter-relação comunicação/educação.

- O graduando que se prepara para a atuação docente tem uma relação de proximidade com os recursos tecnológicos. Os questionários e entrevistas apontaram que os estudantes de Letras e de Pedagogia da USP e da UNICSUL estão conectados e têm familiaridade com os recursos tecnológicos, os quais fazem parte de seu dia a dia. Embora não exista um conhecimento aprofundado de programas informáticos, há uma relação de proximidade com a tecnologia. Entre os futuros professores, alguns (em geral os mais jovens) lidam com os recursos com grande naturalidade; outros tiveram que se esforçar para aprender, porém todos estão plenamente inseridos nesse contexto.

- O estudante que se prepara para a profissão docente acredita na importância da integração entre comunicação e educação, mas necessita de orientação sobre como traduzir essa inter-relação em suas práticas de ensino. A visão sobre a importância de aproximar os dois campos foi unânime, porém a maioria dos pesquisados disse que gostaria de uma formação específica para desenvolver o trabalho na prática. O discurso do futuro professor está carregado de referências midiáticas e ele tem consciência de que o aluno também compartilha essas referências, por isso defende que o tema seja 
tratado em sala de aula. No entanto, admite que não se sente preparado para trabalhar outras linguagens ou que gostaria de uma maior orientação.

- Mesmo que tenha familiaridade com os recursos tecnológicos, o futuro professor tende a fazer uso instrumental da tecnologia na educação formal. A pesquisa mostrou que, salvo poucas exceções, a tecnologia é considerada uma ferramenta para auxiliar o trabalho do professor, e não instância de mediação do processo de aprendizagem e da sociedade. Há uma apreensão instrumental da tecnologia, vista como um elemento externo que deve ser introduzido na escola por meio de equipamentos. $\mathrm{O}$ futuro professor tende a reproduzir o reducionismo identificado no sistema educativo em relação ao âmbito comunicativo: as tecnologias de informação e comunicação são usadas como um complemento ao ensino, e não como potencializadoras da capacidade comunicacional humana, negligenciando seu poder transformador.

Além disso, consideramos parcialmente rejeitada a seguinte hipótese:

- O futuro professor vê a recepção do aluno de maneira homogênea, e não como uma nova produção de sentidos, sem identificar que as novas formas de circulação do conhecimento geradas pelos meios de comunicação e pelas tecnologias interferem na recepção da mensagem. De forma alguma os participantes da pesquisa consideraram a recepção do aluno de maneira homogênea: eles percebem que a produção de sentidos na sala de aula é uma construção que depende do contexto e de elementos mediativos. $\mathrm{O}$ futuro professor reconhece que existem novas formas de circulação do conhecimento e que elas interferem no processo de aprendizagem dentro da escola. No entanto, não consideramos a hipótese totalmente rejeitada porque muitos pesquisados, ao falarem da recepção fora do espaço escolar, demonstraram uma visão unidirecional e homogênea do sentido, acreditando que a televisão tem impacto direto no jovem receptor, sem considerar as mediações que interferem na construção do significado. 


\section{CONSIDERAÇÕES FINAIS}

Ao chegar ao final da pesquisa, ou melhor, ao estabelecer um ponto final para a pesquisa, visto que a investigação qualitativa abre um vasto campo de análises, consideramos que cumprimos os objetivos propostos no início, pois verificamos qual a formação que o professor recebe na universidade para promover a inter-relação comunicação/educação, bem como o posicionamento do futuro profissional sobre questões envolvendo a comunicação na escola. Também verificamos que, embora o graduando defenda o uso de meios de comunicação em sala de aula, não sabe como transportá-los às suas práticas de ensino. Identificamos ainda que o professor que está saindo da universidade tem uma relação de proximidade com a mídia e os recursos tecnológicos, pois essas linguagens fazem parte de seu dia a dia. $\mathrm{O}$ futuro docente tem o hábito de ver televisão, assistir a filmes e navegar na internet, sinal de que ele compartilha campos semânticos com o aluno, o que contribui para aproximar educador e educando, desde que esses interesses comuns sejam expostos, sem receio de "perder autoridade" frente ao estudante. Ainda há desconfiança em relação ao impacto das mensagens televisivas sobre os alunos, porém, ao mesmo tempo, há disposição para trabalhar com esse meio em sala de aula e ajudar o jovem a desenvolver um novo olhar.

Percebemos, ao longo de nossa pesquisa, que o futuro professor sente falta de um aspecto prático em sua formação. Ele, de forma alguma, descarta a importância dos estudos teóricos, da reflexão, mas sente necessidade de uma orientação no sentido das práticas escolares, especialmente no que se refere à utilização dos meios de comunicação e das novas tecnologias em sala de aula. Há um consenso sobre a necessidade de recorrer a essas linguagens para se aproximar do aluno e estabelecer um processo comunicativo de fato, no entanto, há uma tendência a usá-las como meros suportes da aula, e podemos notar uma clara insegurança sobre como desenvolver o trabalho. A formação na universidade, embora esteja dando os primeiros passos nessa direção, ainda não atende à requisição. As disciplinas voltadas para a inter-relação comunicação/educação, quando existem, constam da grande optativa dos cursos, muitas vezes ministradas em períodos do dia que não correspondem ao turno regular. Mesmo aqueles graduandos que afirmam estar preparados para trabalhar outras linguagens destacam que isso é resultado de suas próprias vivências, de seu interesse pelas mídias, de sua experimentação. Há um conhecimento experimental, há interesse, vontade, porém falta sistematizar esses elementos para transportá-los à sala de aula. Para ajudar o aluno a deixar de ser apenas receptor e alcançar a produção comunicativa possibilitada 
pela conversão tecnológica, e assim exercer o poder transformador, o docente também precisa ser preparado para fazer essa transição. A nova geração de professores demonstrou ter condições de chegar a esse patamar, pois está inserida no mesmo contexto do jovem em processo de escolarização, fazendo do contato com os meios de comunicação e as novas tecnologias uma experiência cotidiana, o que contribui para afastar estereótipos e desconfianças comumente identificados no sistema de ensino. No entanto, é essencial superar a visão instrumental das tecnologias da informação e comunicação, muitas vezes reproduzida pela própria universidade, como ocorre com a plataforma interativa usada como depositário de textos.

Os futuros docentes acreditam numa educação libertadora, em que a sala de aula seja um espaço de diálogo, de construção do conhecimento, onde eles possam exercer o papel de mediadores do processo de aprendizagem. Porém, quando vivenciam a experiência, já no momento do estágio, sofrem desilusões ao esbarrar no modelo escolar tradicional, baseado em hierarquia, coerção e exclusão, e ao encontrar dificuldades com as quais não foram preparados para lidar. Consequentemente, acabam recorrendo a ações coercitivas, contrariando seu próprio discurso. A tensão discursiva vivida pelo professor novato é evidente, no entanto, ainda mais patente é a vontade de acertar, de fazer a diferença na vida do aluno. Há plena consciência da responsabilidade da profissão que escolheram e disposição para exercer o trabalho da melhor maneira possível, ainda que encontrem obstáculos e desafios, o que certamente é essencial para chegar à educação emancipatória.

Mesmo atuando como professores eventuais, alguns já conseguem fazer da aula um processo comunicativo, estabelecendo diálogo com os educandos e articulando diferentes linguagens, porém a maioria sente necessidade de orientação para alcançar esse objetivo. A inter-relação comunicação/educação pede o entendimento dos processos de formação à luz das mediações, com a escola dialogando criticamente com os meios de comunicação e esses, por sua vez, sendo vistos não apenas como agências de entretenimento, descompromisso e manipulação. À universidade cabe otimizar seu papel, possibilitando aos futuros professores entenderem melhor os significados e os mecanismos das novas linguagens, e não apenas se deslumbrarem diante dos aparatos técnicos. A educação enquanto formação, no sentido que definimos com Bolle no início de nossa discussão, de um autodesenvolver-se, com independência, liberdade e autonomia, depende, prioritariamente, dos professores. Mas, para que eles tenham condições de contribuir com essa formação, precisam também conquistar a autonomia. 
Ao compreenderem as dinâmicas da sociedade da informação e da comunicação, que gera novas formas de produzir, circular e receber o conhecimento, poderão se apropriar dos meios de comunicação e das novas tecnologias como mediadores das relações sociais e da construção de sentidos. E, a partir daí, desenvolver um trabalho com outras linguagens em sala de aula que permita despertar novos olhares e levar à produção comunicativa, encontrando no jogo dialógico o caminho para construir sujeitos livres e conscientes de seu papel democrático e do seu poder transformador. 


\section{REFERÊNCIAS BIBLIOGRÁFICAS}

ADORNO, Theodor W. “A indústria cultural”. In COHN, Gabriel (org.) Comunicação e Indústria Cultural. São Paulo: T. A. Queiroz, 1989.

Educação e Emancipação. 4 ed. Paz e Terra: Rio de Janeiro, 1995.

BAKHTIN, Mikhail. Marxismo e filosofia da linguagem. São Paulo: Hucitec, 1992.

BOLLE, Willi. A ideia de formação na mordenidade. In: GHIRALDELLI JR., Paulo (org). Infância, Escola e Modernidade. Cortez: São Paulo, Editora UFPR: Curitiba, 1997.

BOURDIEU, Pierre et al. A profissão de sociólogo. Petrópolis: Vozes, 1999.

BRUNNER, José Joaquim. Educação no encontro com as novas tecnologias. In TEDESCO, Juan Carlos. Educação e novas tecnologias: esperança ou incerteza?. Cortez: São Paulo, 2004.

CITELLI, Adilson. Comunicação e Educação. A linguagem em movimento. Senac: São Paulo, 2000.

[org]. Educação e Mudanças: novos modos de conhecer. In: CITELLI. Adilson (org). Outras linguagens na escola. Cortez: São Paulo, 2000.

Mídia e escola: apresentando uma pesquisa. Anais do XXXI Congresso Brasileiro de Ciências da Comunicação - Intercom: Natal (RN), 2008.

2006.

Palavras, meios de comunicação e educação. São Paulo: Cortez,

CROVI, Delia (2006). Educar em la era de redes. México, D.F.: Unam, 2006.

FIGARO, Roseli. Atividade de comunicação e trabalho. Revista Trabalho, Educação e Saúde. Rio de Janeiro: Fiocruz, v. 6, n. 1, 2008[A].

AnnaBlume, 2008.

Relações de comunicação no mundo do trabalho. São Paulo: 
FILMUS, Daniel. Breves reflexões sobre a escola do futuro e apresentação da experiência "aulas na rede" da cidade de Buenos Aires. In: TEDESCO, Juan Carlos. Educação e novas tecnologias: esperança ou incerteza?. Cortez: São Paulo, 2004.

FOUCAULT, Michel. A ordem do discurso. 15 ed. São Paulo: Loyola, 2007.

FRANCO, Marilia. Você sabe o que foi o I.N.C.E.?. In: SETTON, Maria da Graça Jacintho. A cultura da mídia na escola: ensaios sobre cinema e educação. São Paulo: Annablume, 2004.

FREIRE, Paulo. Extensão ou Comunicação? São Paulo: Paz e Terra, 13 ed., 1996. Pedagogia da autonomia. 39 ed. Paz e Terra: São Paulo, 1996.

GOHN, Maria da Glória. Educação não-formal e cultura política. 4 ed. Cortez: São Paulo, 2008.

GRINSPUM, Mírian (org.). Educação tecnológica. Cortez: São Paulo, 2002.

KAPLÚN, Mário. Processos educativos e canais de comunicação. Comunicação \& Educação. São Paulo: ECA/USP-Editora Segmento, Ano VI, jan./abr. 1999.

LOPES, Maria Immacolata V. Estratégias metodológicas da pesquisa de recepção. In: Revista Intercom, nº 2, 1993.

O campo da comunicação: reflexões sobre seu estatuto disciplinar. Revista USP, $\mathrm{n}^{\circ} 48$.

Pesquisa em Comunicação. São Paulo: Loyola, $7^{\mathrm{a}}$ ed., 2005.

MARTÍN-BARBERO, Jesús. Cultura e nuevas mediaciones tecnológicas. Texto apresentado durante a disciplina "Novas sensibilidades: entre urbanias e cidadanias", ministrada de 15 a 19 de setembro de 2008, na Eca/USP. São Paulo, 2008.

Ensanchando territórios em comunicación/educación. In: VALDERRAMA, Carlos, Comunicación \& Educación. Universidad Central: Bogotá, 2000. 
Heredando el futuro. Pensar la educación desde la comunicación. In: Revista Nómadas. Fundación Universidad Central, número 5: Bogotá, 1996.

Tecnicidades, identidades, alteridades: mudanças e opacidades da comunicação no novo século. In: MORAES, Denis. Sociedade midiatizada. Mauad: Rio de Janeiro, 2006.

MARTÍNEZ, Jorge H. Gutiérrez. Novas tecnologias e o desafio da educação. In TEDESCO, Juan Carlos. Educação e novas tecnologias: esperança ou incerteza?. Cortez: São Paulo, 2004.

MORIN, Edgard. A cabeça bem-feita. Rio de Janeiro: Bertrand, 2000.

O paradigma complexo. Introdução ao paradigma complexo. Porto Alegre: Sulina. 2006.

NÓVOA, António. Professores: imagens do futuro presente. Educa: Lisboa, 2009.

OROZCO GÓMEZ, Guillermo. Professores e meios de comunicação: desafios e estereótipos. In: Revista Comunicação e Educação. n ${ }^{\circ}$ 10. São Paulo, Moderna/CCA, 1997.

De la enseñanza al aprendizaje: desordenamientos educativo-comunicativos en los tiempos, escenarios y processos de conocimiento. In: Revista Nómadas. Fundación Universidad Central, número 21. Bogotá, 2004.

. Entre pantallas: nuevos roles comunicativos de las audiencias. Curitiba: Congresso da Intercom, 2009.

Grupo Editorial Norma, 2001.

. Televisión, audiencias e educacion. Buenos Aires:

PERRENOUD, Philippe. As competências para ensinar no século XXI. Artmed: Porto Alegre, 2002.

PENTEADO, Heloisa Dupas. Pedagogia da comunicação: sujeitos comunicantes. In: PENTEADO, Heloisa Dupas (org.). Pedagogia da comunicação: teorias e práticas. São Paulo: Cortez, 2001. 
PORTO, Tania Maria Speron. Educação para a mídia/pedagogia da comunicação. In: PENTEADO, Heloisa Dupas (org.). Pedagogia da comunicação: teorias e práticas. São Paulo: Cortez, 2001.

RODRIGUES, Gabriela F. Projeto de intervenção educomunicativa no Colégio Elvira Brandão. Trabalho apresentado à ECA/USP como requisito parcial para obtenção do título de especialista em nível de pós-graduação em Gestão de Processos Comunicacionais. São Paulo, 2006.

SETTON, Maria da Graça Jacintho. Cinema: instrumento reflexivo e pedagógico. In: SETTON, Maria da Graça Jacintho. A cultura da mídia na escola: ensaios sobre cinema e educação. São Paulo: Annablume, 2004.

SOARES, Ismar de Oliveira. Comunicação/Educação: a emergência de um novo campo e o perfil de seus profissionais. Revista Contato, Brasília: Ano 1, nº 1, jan/mar 1999.

Ecossistemas comunicativos. [S.I.]: Núcleo de Comunicação e Educação da Universidade de São Paulo, [S.D.]. Disponível em: http://www.USP.br/nce/aeducomunicacao/saibamais/textos.

Gestão comunicativa e educação: caminhos da educomunicação. Comunicação \& Educação. São Paulo: ECA/USP-Editora Segmento, Ano VIII, jan/abr. 2002, n 23

- Metodologias da Educação para Comunicação e Gestão Comunicativa no Brasil e na América Latina. In: BACCEGA, Maria Aparecida (org). Gestão de Processos Comunicacionais. São Paulo: Atlas, 2001.

THIOLLENT, Michel J. M. Crítica metodológica, investigação social e enquete operária. São Paulo: Polis, 1980.

WITTGENSTEIN, Ludwig. Investigações filosóficas. 4 ed. Bragança Paulista: Editora Universitária São Francisco; Petrópolis: Vozes, 2005.

WOLTON, Dominique. É preciso salvar a comunicação. Paulus, São Paulo: 2006. 
ANEXO

\section{PORTARIA N 4.059, DE 10 DE DEZEMBRO DE 2004 (DOU de 13/12/2004, Seção 1, p. 34)}

O MINISTRO DE ESTADO DA EDUCAÇÃO, no uso de suas atribuições, considerando o disposto no art. 81 da Lei no 9.394, de 20 de dezembro de 1996, e no art. 1o do Decreto no 2.494, de 10 de fevereiro de 1998, resolve:

Art. ${ }^{\circ}$. As instituições de ensino superior poderão introduzir, na organização pedagógica e curricular de seus cursos superiores reconhecidos, a oferta de disciplinas integrantes do currículo que utilizem modalidade semi-presencial, com base no art. 81 da Lei n. 9.394, de 1.996, e no disposto nesta Portaria.

$\S 1^{\circ}$. Para fins desta Portaria, caracteriza-se a modalidade semi-presencial como quaisquer atividades didáticas, módulos ou unidades de ensino-aprendizagem centrados na auto-aprendizagem e com a mediação de recursos didáticos organizados em diferentes suportes de informação que utilizem tecnologias de comunicação remota.

$\S 2{ }^{\circ}$. Poderão ser ofertadas as disciplinas referidas no caput, integral ou parcialmente, desde que esta oferta não ultrapasse $20 \%$ (vinte por cento) da carga horária total do curso.

$\S 3^{\circ}$. As avaliações das disciplinas ofertadas na modalidade referida no caput serão presenciais.

$\S 4$. A introdução opcional de disciplinas previstas no caput não desobriga a instituição de ensino superior do cumprimento do disposto no art. 47 da Lei no 9.394, de 1996, em cada curso superior reconhecido.

Art. $2^{\circ}$. A oferta das disciplinas previstas no artigo anterior deverá incluir métodos e práticas de ensino-aprendizagem que incorporem o uso integrado de tecnologias de informação e comunicação para a realização dos objetivos pedagógicos, bem como prever encontros presenciais e atividades de tutoria.

Parágrafo único. Para os fins desta Portaria, entende-se que a tutoria das disciplinas ofertadas na modalidade semi-presencial implica na existência de docentes qualificados em nível compatível ao previsto no projeto pedagógico do curso, com carga horária específica para os momentos presenciais e os momentos a distância.

Art. $3^{\circ}$. As instituições de ensino superior deverão comunicar as modificações efetuadas em projetos pedagógicos à Secretaria de Educação Superior - SESu -, do Ministério da Educação - MEC -, bem como inserir na respectiva Pasta Eletrônica do Sistema SAPIEns, o plano de ensino de cada disciplina que utilize modalidade semipresencial.

Art. $4^{\circ}$. A oferta de disciplinas na modalidade semi-presencial prevista nesta Portaria será avaliada e considerada nos procedimentos de reconhecimento e de renovação de reconhecimento dos cursos da instituição.

Art. 5 . Fica revogada a Portaria n. 2.253/2001, de 18 de outubro de 2001, publicada no Diário Oficial da União de 19 de outubro de 2001, Seção 1, páginas 18 e 19.

Art. $6^{\circ}$. Esta Portaria entra em vigor na data de sua publicação.

\section{TARSO GENRO}


